\title{
CONTROLE DE PERDAS NA ENSILAGEM, DESEMPENHO E DIGESTÃO DE NUTRIENTES EM BOVINOS DE CORTE ALIMENTADOS COM RAÇÕES CONTENDO SILAGENS DE CAPIM TANZÂNIA
}

SOLIDETE DE FÁTIMA PAZIANI

Tese apresentada à Escola Superior de
Agricultura "Luiz de Queiroz", Universidade de
São Paulo, para obtenção do título de Doutor em
Agronomia, Área de Concentração: Ciência
Animal e Pastagens.

PIR A C I C A B A

Estado de São Paulo - Brasil

Agosto - 2004 


\title{
CONTROLE DE PERDAS NA ENSILAGEM, DESEMPENHO E DIGESTÃO DE NUTRIENTES EM BOVINOS DE CORTE ALIMENTADOS COM RAÇÕES CONTENDO SILAGENS DE CAPIM TANZÂNIA
}

\author{
SOLIDETE DE FÁTIMA PAZIANI \\ Zootecnista
}

Orientador: Prof. Dr. LUIZ GUSTAVO NUSSIO

Tese apresentada à Escola Superior de
Agricultura "Luiz de Queiroz", Universidade de
São Paulo, para obtenção do título de Doutor em
Agronomia, Área de Concentração: Ciência
Animal e Pastagens.

PI R A C I C A B A

Estado de São Paulo - Brasil

Agosto - 2004 
Dados Internacionais de Catalogação na Publicação (CIP)
DIVISÃO DE BIBLIOTECA E DOCUMENTAÇÃO - ESALQ/USP

Paziani, Solidete de Fátima

Controle de perdas na ensilagem, desempenho e digestão de nutrientes em bovinos de corte alimentados com rações contendo silagens de capim Tanzânia /Solidete de Fátima Paziani. - - Piracicaba, 2004.

$208 \mathrm{p}$.

Tese (doutorado) - Escola Superior de Agricultura Luiz de Queiroz, 2004.

Bibliografia.

1. Bovinos de corte 2. Capim-Tanzânia 3. Desempenho animal 4. Nutrição animal 5. Silagem I. Título

CDD 636.213

\section{"Permitida a cópia total ou parcial deste documento, desde que citada a fonte - $\mathrm{O}$ autor"}


Cada um que passa em nossa vida, passa sozinho pois cada pessoa é única, e nenhuma substitui outra.

Cada um que passa em nossa vida, passa sozinho, mas não sai só, nem nos deixa só: leva um pouco de nós mesmos, deixam um pouco de si mesmos.

Há os que levam muito, mas não há os que não deixam nada.

Essa é a maior responsabilidade de nossa vida.

É a prova evidente que duas almas não se encontram ao acaso.

Saint Exupéry 
A todos que fizeram parte da EQUIPE, sem a qual teria sido impossível conduzir as atividades propostas, um círculo de amizades que foi além do trabalho e traduziu-se no companheirismo de todos os dias, sempre mantendo o respeito e o espírito de participação.

DEDICO

À toda minha família, em especial aos meus pais, Armando e Matilde, aos meus irmãos, Solange, Maurício, Marcelo e Marcos e à minha sobrinha Júlia, pelo incentivo e pelos momentos de alegria. 


\section{AGRADECIMENTOS}

Ao Prof. Dr. Luiz Gustavo Nussio, pela orientação na elaboração e condução do projeto e acompanhamento em todas as atividades desenvolvidas durante o curso.

Ao Prof. Dr. Alexandre Vaz Pires, pela oportunidade inicial e pela execução das cirurgias nos animais utilizados no experimento.

À Escola Superior de Agricultura "Luiz de Queiroz" (ESALQ/USP), especialmente ao Departamento de Zootecnia /Setor de Ruminantes.

À Fundação de Apoio à Pesquisa do Estado de São Paulo (FAPESP) pela concessão da bolsa de estudos e pelo financiamento do projeto através dos recursos disponibilizados na reserva técnica.

Ao Prof. Dr. Flávio A. P. Santos pelo auxílio e colaboração no trabalho através da formulação das rações.

Ao Prof. Dr. Irineu Umberto Packer, pela valiosa ajuda, sugestões, e paciência, na análise estatística dos dados.

A todos os professores do Departamento de Zootecnia pelos ensinamentos, orientação e amizade.

Ao Dr. Fábio P. Campos e à Dra. Carla Nussio pelo constante auxílio nas tarefas laboratoriais e amizade.

A todos os estagiários que passaram pelo Departamento durante a condução dos experimentos, participando das atividades.

Aos amigos Patrícia, Adriana, André, Chico, Rodrigo (Poço), Rodrigo (BH), Flávio, Ricardo Manzano, Maurício, Daniele, Lucas, José Leonardo, Maity, Marta, Mariele, Patrick, Juliano (Gomão) pelo apoio, amizade, companheirismo e auxílio na condução das atividades durante o curso. 
Às amigas Ana Paula, Valéria, Joceli e Janaína, que sempre participaram, mesmo distantes, de toda minha trajetória.

Ao funcionário do Laboratório de Bromatologia do Departamento de Zootecnia, Carlos César Alves, pela colaboração, paciência e amizade durante as análises laboratoriais.

A todos os funcionários do Departamento de Zootecnia, que participaram na condução dos experimentos.

A todos que, de alguma forma, fizeram parte desta fase, participando direta ou indiretamente na realização dos trabalhos ou simplesmente dividindo momentos fora do ambiente de trabalho.

A Deus, a quem sempre recorri em momentos de necessidade, e fui atendida, tendo meus pedidos realizados.

A todos, meu muito obrigada! 


\section{SUMÁRIO}

Página

LISTA DE FIGURAS..........................................................................

LISTA DE TABELAS............................................................. xiv

LISTA DE ABREVIATURAS..........................................................

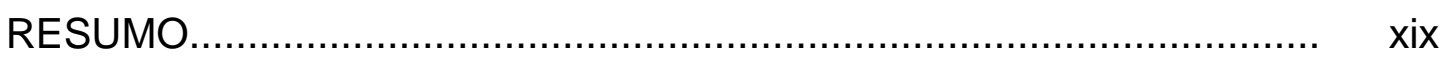

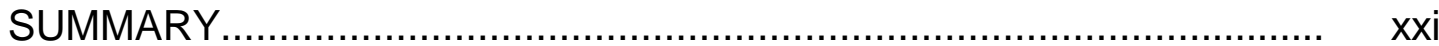

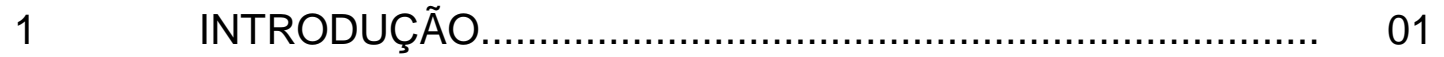

2 REVISÃO DE LITERATURA............................................ 05

2.1 Gramíneas do gênero Panicum maximum........................... 05

$2.2 \quad$ Silagens de gramíneas tropicais.......................................... 06

$2.3 \quad$ Teor de matéria seca.................................................... 12

2.4 Tamanho de partículas.................................................. 16

$2.5 \quad$ Inoculantes bacterianos.............................................. 18

2.6 Perdas no processo de ensilagem: do campo ao cocho....... 21

2.7 Fatores que interferem na resposta de animais..................... 25

2.7.1 Aspectos da cinética ruminal e comportamento ingestivo...... 25

2.7.2 Desempenho de animais................................................... 28

3 EFEITO DO TAMANHO DE PARTÍCULA, TEOR DE MATÉRIA SECA E INOCULANTE BACTERIANO SOBRE A QUALIDADE E O CONTROLE DAS PERDAS NA SILAGEM DE CAPIM TANZÂNIA.................................................... 33

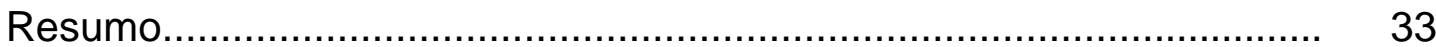




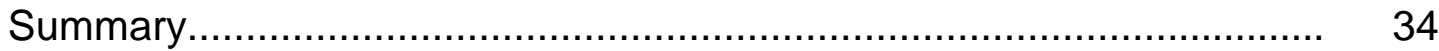

Introdução............................................................ 35

3.2 Material e Métodos.............................................................. 37

3.2.1 Local do experimento................................................... 37

3.2.2 Silos experimentais........................................................ 37

3.2.3 Espécie vegetal e tratamentos adotados............................. 38

3.2.4 Colheita da forragem e avaliações no campo.......................... 39

3.2.5 Aplicação dos tratamentos ................................................ 40

3.2.6 Delineamento experimental............................................ 41

3.2.7 Procedimento de enchimento dos silos experimentais........... 41

3.2.8 Abertura dos silos experimentais...................................... 42

3.2.8.1 Determinação das perdas por gases.................................... 42

3.2.8.2 Determinação da produção de efluente................................. 43

3.2.8.3 Determinação do índice de recuperação de matéria seca...... 43

3.2.9 Amostragem da forragem na ensilagem e das silagens na

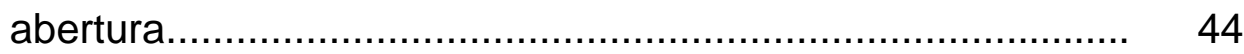

3.2.10 Análises químico-bromatológicas das amostras coletadas.... 44

3.2.10.1 Determinação da condutividade elétrica (CE) das forragens

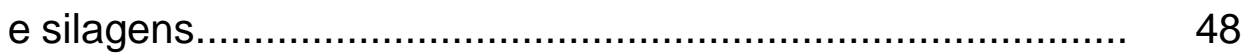

3.2.10.2 Determinação do tamanho de partículas das forragens e

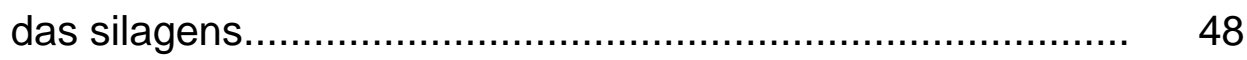

3.2.10.3 Extrato aquoso: pH, carboidratos solúveis, nitrogênio amoniacal e poder tampão............................................... 50

3.2.11 Análise estatística......................................................... 50

3.3 Resultados e Discussão...................................................... 51

3.3.1 Produção da área colhida e perdas no processo de colheita. 51

3.3.2 Aspectos físicos das silagens............................................ 52

3.3.2.1 Tamanho de partícula das silagens..................................... 52

3.3.2.2 Condutividade elétricas (CE) das silagens........................... 54

3.3.2.3 Densidades de massa verde (DMV) das silagens................. 55 
3.3.2.4 Densidades de matéria seca (DMS) das silagens................. 57

3.3.2.5 Perdas por gases das silagens........................................... 58

3.3.2.6 Produção de efluente das silagens...................................... 59

3.3.2.7 Índice de recuperação de matéria seca (RMS) das silagens.. $\quad 60$

3.3.3 Composição químico-bromatológica das silagens.................. 62

3.3.3.1 Teor de matéria seca (MS) das silagens............................. 62

3.3.3.2 Teor de cinzas (CZ) das silagens...................................... 65

3.3.3.3 Teor de proteína bruta (PB) das silagens............................. 66

3.3.3.4 Teor de nitrogênio amoniacal $\left(\mathrm{N}-\mathrm{NH}_{3}\right)$ das silagens.............. 68

3.3.3.5 Teor de nitrogênio insolúvel em detergente ácido (N-FDA).... 70

3.3.3.6 Teor de fibra insolúvel em detergente neutro (FDN) das

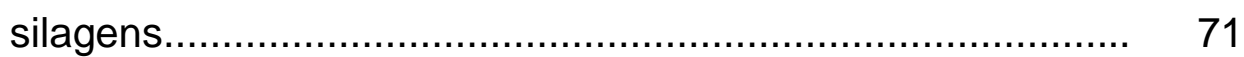

3.3.3.7 Teor de fibra insolúvel em detergente ácido (FDA) das

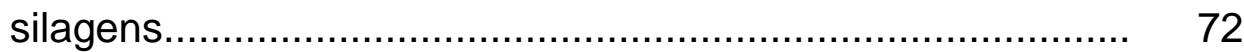

3.3.3.8 Teor de lignina das silagens............................................. 73

3.3.3.9 Teor de hemicelulose das silagens.................................... 74

3.3.3.10 Teor de celulose das silagens.......................................... 74

3.3.3.11 Teor de carboidratos solúveis (CS) das silagens.................. 75

3.3.3.12 pH das silagens ........................................................ 78

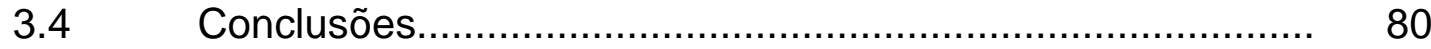

4 EFEITO DO TAMANHO DE PARTÍCULA, TEOR DE MATÉRIA SECA E INOCULANTE BACTERIANO EM SILAGEM DE CAPIM TANZÂNIA SOBRE O COMPORTAMENTO INGESTIVO E DIGESTÃO DE NUTRIENTES EM BOVINOS DE CORTE.......................... 81

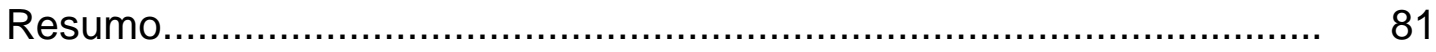

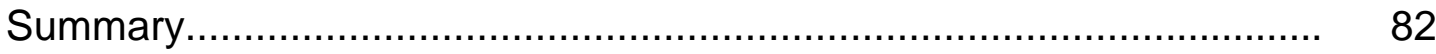

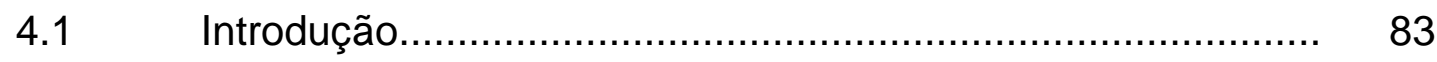

$4.2 \quad$ Material e Métodos........................................................ 86

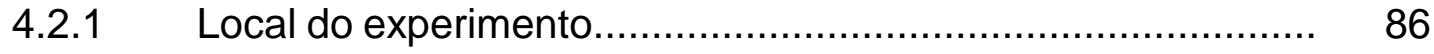




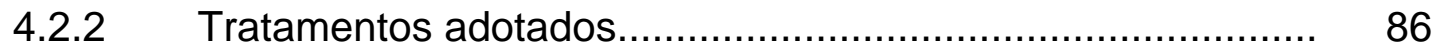

4.2.2.1 Aplicação dos tratamentos................................................ 87

4.2.3 Confecção da silagem.......................................................... 88

4.2.4 Período experimental, animais utilizados e rações................. 89

4.2.5 Amostragem dos alimentos e das sobras e análises

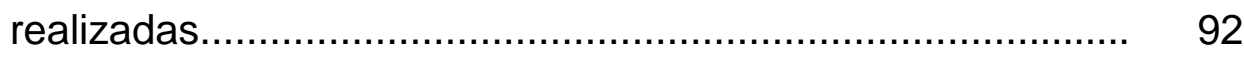

4.2.5.1 Análises químico-bromatológicas......................................... 92

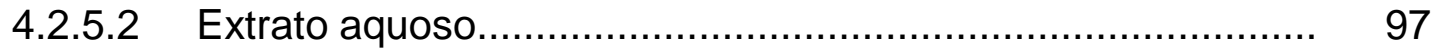

4.2.5.3 Determinação do tamanho de partícula................................ 97

4.2.6 Atividades durante o período de avaliação............................. 97

4.2.6.1 Comportamento ingestivo.............................................. 97

4.2.6.2 Determinação do desaparecimento intestinal através da técnica de sacos móveis.................................................. 98

4.2.6.3 Parâmetros ruminais.......................................................... 99

4.2.6.4 Determinação da taxa de passagem................................... 100

4.2.6.5 Coleta de amostras para determinação da digestibilidade

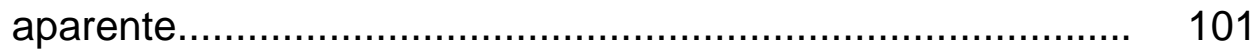

4.2.6.6 Determinação da degradabilidade in situ.............................. 102

4.2.7 Análise estatística......................................................... 105

4.3 Resultados e Discussão ................................................. 106

4.3.1 Avaliação das rações experimentais...................................... 106

4.3.1.1 Composição químico-bromatológica das silagens e das rações completas......................................................... 106

4.3.2 Cinética, ingestão e comportamento ingestivo dos animais... 111

4.3.2.1 Ingestão de matéria seca................................................... 111

4.3.2.2 Taxa de passagem e tempo médio de retenção....................... 115

4.3.2.3 Comportamento ingestivo do animal.................................... 117

4.3.3 Digestibilidade aparente no trato digestivo........................... 120

4.3.4 Parâmetros ruminais.......................................................... 125

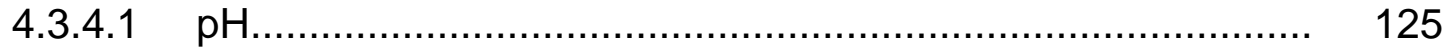


4.3.4.2 Evolução temporal da concentração do $\mathrm{pH}$ ruminal............... 127

4.3.4.3 Ácidos graxos voláteis (AGV) ........................................ 129

4.3.4.4 Evolução temporal da concentração de ácidos graxos........... 132

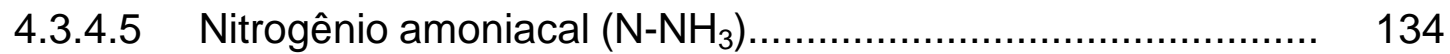

4.3.4.6 Evolução temporal da concentração de nitrogênio amoniacal 135

4.3.5 Degradabilidade in situ................................................. 136

4.3.5.1 Degradabilidade in situ da matéria seca.............................. 136

4.3.5.2 Degradabilidade in situ da FDN........................................ 139

4.3.5.3 Degradabilidade in situ da FDA........................................ 141

4.3.5.4 Degradabilidade in situ da hemicelulose............................... 143

4.3.6 Desaparecimento intestinal................................................. 144

$4.4 \quad$ Conclusões.................................................................. 148

5 EFEITO DO TAMANHO DE PARTÍCULA, TEOR DE MATÉRIA SECA E INOCULANTE BACTERIANO SOBRE OS PARÂMETROS FÍSICOS E PERDAS POR DETERIORAÇÃO, EM SILAGEM DE CAPIM TANZÂNIA ARMAZENADA EM SILOS TUBULARES REVESTIDOS COM LONA PLÁSTICA, E SOBRE O DESEMPENHO DE BOVINOS DE CORTE................................................. 149

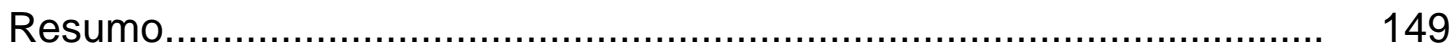

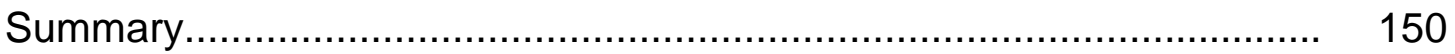

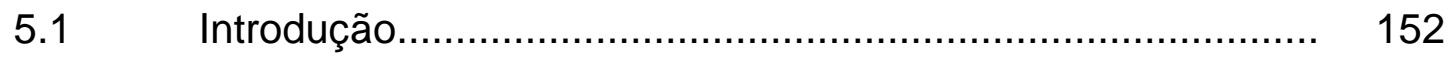

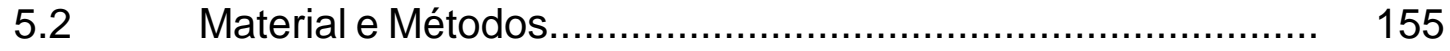

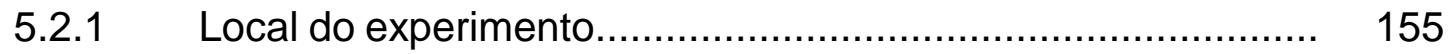

5.2.2 Tratamentos adotados................................................ 156

5.2.3 Confecção dos silos e aplicação dos tratamentos.................. 156

5.2.4 Animais, instalações e rações................................................ 161

5.2.5 Procedimento experimental............................................. 163

5.3 Análises realizadas........................................................ 164

5.3.1 Análises químico-bromatológicas.......................................... 164 


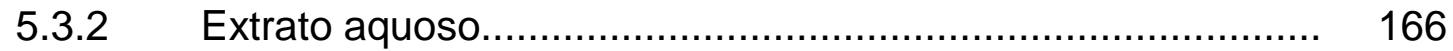

5.3.4 Avaliações dos parâmetros físicos........................................ 167

5.4 Delineamento experimental e análise estatística.................... 168

$5.5 \quad$ Resultados e Discussão....................................................... 168

5.5.1 Parâmetros físicos das silagens e perdas por deterioração... 168

5.5.2 Composição das silagens e formulação das rações................................................................... 177

5.5.3 Ingestão de matéria seca, ganho de peso e conversão alimentar.............................................................. 179

5.6 Conclusões................................................................ 184

$6 \quad$ CONCLUSÕES GERAIS.................................................. 185

REFERÊNCIAS BIBLIOGRÁFICAS.................................................... 187 


\section{LISTA DE FIGURAS}

Página

1 Efeito das rações experimentais sobre a evolução temporal do $\mathrm{pH}$ no fluido ruminal................................................. 128

2 Efeito das rações experimentais sobre a evolução temporal da concentração de nitrogênio amoniacal no fluido ruminal... 135 


\section{LISTA DE TABELAS}

Página

1 Composição químico-bromatológica das forragens no momento da ensilagem.

2 Parâmetros físicos das silagens de capim Tanzânia submetidas aos efeitos do teor de matéria seca e uso de inoculante bacteriano na ensilagem

3 Composição químico-bromatológica das silagens de capim Tanzânia submetidas aos efeitos do teor de matéria seca e uso de inoculante bacteriano na ensilagem.

4 Composição das forragens ensiladas nos silos tipo poço, submetidas a teores de matéria seca e tamanho de partículas na ensilagem

5 Proporção dos ingredientes nas rações oferecidas aos animais durante o período experimental.

6 Médias das variáveis de composição bromatológica observadas para ingredientes utilizados nas rações.

7 Médias das variáveis de composição bromatológica observadas para as rações completas à base de silagens de capim Tanzânia.

8 Valores para ingestão de MS e FDN, taxas de passagem de sólidos e líquidos e tempo médio de retenção (TMR) em bovinos recebendo rações à base de silagens de capim 
Tanzânia

9 Variáveis do comportamento ingestivo em bovinos que receberam rações contendo silagens de capim Tanzânia.........

10 Valores de digestibilidade (\%) aparente dos nutrientes no trato total, obtidos por coleta total de fezes, em bovinos alimentados com rações à base de silagem de capim Tanzânia.

11 Médias para variáveis ruminais observadas em bovinos recebendo rações contendo silagens de capim Tanzânia........

12 Evolução temporal para as variáveis ruminais observadas em bovinos recebendo rações contendo silagens de capim Tanzânia.

13 Variáveis da degradabilidade in situ da matéria seca e FDN de silagens de capim Tanzânia.

14 Variáveis da degradabilidade in situ da FDA e hemicelulose de silagens de capim Tanzânia.

15 Desaparecimento intestinal e estimativa de degradação no trato total de frações fibrosas de amostras de silagens de capim Tanzânia, com composição original ou pré-degradadas no rúmen por 12 horas.

16 Composição químico-bromatológica e variáveis físicas da forragem ensilada em silos tubulares revestidos por lona plástica.

17 Composição química das silagens de capim Tanzânia e do milheto utilizado.

18 Participação dos ingredientes na formulação das rações experimentais.

19 Composição bromatológicas das rações experimentais

20 Determinação de parâmetros físicos das silagens armazenadas em silos tubulares revestidos por lona 


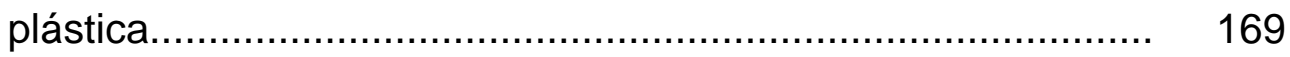

21 Perdas de silagem por deterioração em silos tubulares revestidos por lona plástica................................................. 172

22 Ganho de peso vivo (GPV), ingestão de matéria seca (IMS) e conversão alimentar (CA) em novilhas de corte recebendo rações à base de silagens de capim Tanzânia......................... 


\section{LISTA DE ABREVIATURAS}

C - forragem com inoculante bacteriano.

CA - conversão alimentar.

CE - condutividade elétrica.

CEL - celulose.

CS - carboidratos solúveis.

$\mathrm{CZ}$ - cinzas.

DMS - densidade de matéria seca.

DMV - densidade de matéria verde.

DIVMS - digestibilidade in vitro da matéria seca.

FE - forragem emurchecida.

FDA - fibra insolúvel em detergente ácido.

FDN - fibra insolúvel em detergente neutro.

FF - forragem fresca.

GPV - ganho de peso vivo.

HEMI - hemicelulose.

IMS - ingestão de matéria seca.

$\mathrm{MI}$ - forragem com umidade original e adição de milheto.

MMI - matéria mineral.

MO - forragem com umidade original.

MS - matéria seca.

N-FDA - nitrogênio insolúvel no FDA.

$\mathrm{N}-\mathrm{NH}_{3}$ - nitrogênio amoniacal.

PART - tamanho de partícula. 
PB - proteína bruta.

PMA - partícula maior.

PME - partícula menor.

PT - poder tampão.

$\mathrm{PV}$ - peso vivo.

$S$ - forragem sem inoculante bacteriano.

TMS - teor de matéria seca.

TMR - tempo médio de retenção no trato digestivo.

UFC - unidades formadoras de colônia (inoculante bacteriano). 


\title{
CONTROLE DE PERDAS NA ENSILAGEM, DESEMPENHO E DIGESTÃO DE NUTRIENTES EM BOVINOS DE CORTE ALIMENTADOS COM RAÇÕES CONTENDO SILAGENS DE CAPIM TANZÂNIA
}

\author{
Autor: SOLIDETE DE FÁTIMA PAZIANI \\ Orientador: Prof. Dr. LUIZ GUSTAVO NUSSIO
}

\section{RESUMO}

O presente trabalho teve por objetivo avaliar o efeito do teor de matéria seca (MS), do tamanho de partícula e da adição de inoculante bacteriano sobre as características químico-físicas e perdas no processo de conservação da silagem de capim Tanzânia (Panicum maximum, Jacq. cv. Tanzânia), assim como avaliou o comportamento ingestivo, digestão de nutrientes e o desempenho em bovinos de corte. No experimento I analisou-se o efeito dos tratamentos sobre a fermentação e as perdas na ensilagem. Os índices de recuperação de matéria seca (RMS) e as perdas na forma de efluente e gases foram de 90,58\%; 53,66 kg.t $\mathrm{MV}^{-1}$ e $6,40 \%$ da $M S$ nas silagens nãoemurchecidas, 93,62\%; 16,81 kg.t MV ${ }^{-1}$ e 4,97\% em silagens adicionadas com milheto grão e $92,19 \% ; 3,55$ kg.t $\mathrm{MV}^{-1}$ e $6,16 \%$ nas silagens emurchecidas, respectivamente. $\mathrm{O}$ teor de $\mathrm{MS}$ influenciou a densidade de massa verde e MS, resultando em 346 e $105 \mathrm{~kg} \cdot \mathrm{m}^{-3}$ para silagens emurchecidas, 454 e $144 \mathrm{~kg} \cdot \mathrm{m}^{-3}$ naquelas adicionadas com milheto e 442 e $97 \mathrm{~kg} \cdot \mathrm{m}^{-3} \mathrm{com}$ umidade original, 
respectivamente $\mathrm{O}$ uso do inoculante bacteriano diminuiu a RMS, não alterando o teor de PB e produção de amônia Silagens com adição do milheto tiveram suas frações fibrosas diluídas (FDN, FDA, CEL e HEMI). O experimento II avaliou o comportamento ingestivo e a digestibilidade dos nutrientes em bovinos Nelore providos de cânulas ruminal e duodenal recebendo rações com $87 \%$ de silagem de capim. Não houve efeito de tratamento sobre os valores médios de digestibilidade da MS (61,4\%), FDA (59,7\%), PB (43,9\%) e FDN $(60,3 \%)$, desaparecimento intestinal de MS (5,9\%), FDN $(3,0 \%)$ e FDA $(4,4 \%)$, comportamento ingestivo, parâmetros de degradabilidade ruminal, parâmetros de cinética de passagem de sólidos e líquidos $\left(2,4 \%\right.$ e 3,2\% hora $\left.{ }^{-1}\right)$, nem sobre o consumo médio (1,1\% PV). O experimento III avaliou o efeito dos tratamentos sobre as propriedades físicas e perdas por deterioração da silagem de capim Tanzânia, sobre a ingestão de MS (IMS), o ganho de peso (GPV) e a conversão alimentar (CA) de novilhas Nelore alimentadas com rações completas contendo silagem de capim. A redução no tamanho da partícula não elevou as densidades de matéria seca (DMS) e de matéria verde (DMV) nem reduziu as perdas $(P=0,60)$. O emurchecimento tendeu a diminuir a DMV $\left(460 \mathrm{~kg} \cdot \mathrm{m}^{-3}\right)$, porém não diminui a DMS, devido maior teor de MS, mas elevou as perdas em comparação ao tratamento com adição de milheto grão (29,1 vs $17,9 \%)$. Houve tendência $(P=0,09)$ de aumento nas perdas na presença do inoculante bacteriano. Não houve efeito de tratamentos sobre a IMS (2,36\% PV), GPV $\left(1,03\right.$ kg.animal.dia $\left.{ }^{-1}\right)$ e CA $\left(7,91\right.$ kg MS.kg GPV $\left.{ }^{-1}\right)$. Como os procedimentos adotados na ensilagem não tiveram efeito sobre a RMS, nem sobre os parâmetros ingestivos, digestivos e de desempenho dos animais, a opção pelas práticas a serem adotadas na ensilagem dependerá da ponderação de fatores que facilite a operacionalidade e reduza os custos na confecção da silagem. Sugere-se que a recomendação de práticas na ensilagem considere o controle de perdas integrado, desde a colheita da forragem até o desempenho de animais. 


\title{
CONTROL OF ENSILING LOSSES, PERFORMANCE AND NUTRIENT DIGESTION OF BEEF CATTLE FED WITH RATIONS CONTAINING TANZANIA GRASS SILAGE
}

\author{
Author: SOLIDETE DE FÁTIMA PAZIANI \\ Adviser: Prof. Dr. LUIZ GUSTAVO NUSSIO
}

\section{SUMMARY}

The present trial aimed to study the effect of dry matter content (DM), particle size and bacterial inoculant on the chemical-physical composition and conservation losses of Tanzania grass silage (Panicum maximum, Jacq. cv. Tanzânia), as well evaluated the ingestive behavior, nutrient digestion and performance of beef cattle. The experiment I analyzed the effects of treatments on silage fermentation and losses. DM recovery rate, effluent and gases losses were 90.58\%; 53.66 kg.t wet forage ${ }^{-1}$ and $6.40 \%$ DM for wet silages, 93.62\%; $16.81 \mathrm{~kg} . \mathrm{t}$ wet forage ${ }^{-1}$ and $4.97 \%$ for millet added silages and $92.19 \%$; $3.55 \mathrm{~kg} . \mathrm{t}$ wet forage ${ }^{-1}$ and $6.16 \%$ for wilted silages, respectivelly. DM content influenced wet and dry silo bulk densities, resulting in 346 and $105 \mathrm{~kg} \cdot \mathrm{m}^{-3}$ for wilted silages, 454 and $144 \mathrm{~kg} \cdot \mathrm{m}^{-3}$ for millet aded silages and 442 and $97 \mathrm{~kg} \cdot \mathrm{m}^{-3}$ for wet silages, respectivelly. Bacterial inoculant led to a lower DM recovery and did not alter either CP content or the ammonia yield in the silages. Pearl millet addition determined lower fiber content in the silages (NDF, ADF, CEL and HEMI) due dilution effect. The experiment II acessed the ingestive behavior and nutrient 
digestion of Nellore beef steers ruminally and duodenally cannulated fed $87 \%$ silage TMR diets. The DM (61.4\%), ADF (59.7\%), CP (43.9\%) and NDF (60.3\%) total digestibilities, and the intestinal digestibilities for DM (5.9\%), NDF (3.0\%) and ADF (4.4\%), ingestive behavior, in situ degradability, ruminal passage rate of solid and liquid phases $\left(2,4 \%\right.$ and $3,2 \%$ hour $\left.^{-1}\right)$, and the mean DM intake $(1,1 \%$ BW $)$ were not significantly changed by treatments. Experiment III evaluated the effect of treatments on physical parameters and unloading losses of Tanzania grass silage, DM intake (DMI), performance (BWG) and feed conversion (FC) of Nellore heifers fed TMR containig grass silagen. By reducing the particle size no changes were observed neither in DM (DMD) and wet silo bulk (WD) nor on the unloading losses of silages $(P=0.60)$. The forage wilting tended to reduce WD $\left(460 \mathrm{~kg} \cdot \mathrm{m}^{-3}\right)$, but did not changed the DMD, due to the compensatory higher DM content. However, wilting increased losses when compared to the addition of pearl millet (29.1 vs $17.9 \%$ ). The addition of bacterial inoculant showed a trend $(P=0.09)$ for increased losses. No significantlly differences were observed for the treatments in the DMI $(2.4 \%$ BW), BWG (1.03 kg.animal. $\left.\mathrm{d}^{-1}\right)$ and FC (7.91 kg DM.kg BWG $\left.{ }^{-1}\right)$. The ensiling strategies established in Tanzânia grass silages did not result in significant changes neither in DMR nor in ingestive, digestive and animal performance parameters. According to the observed trend it might be concluded that the strategies adopted during the ensiling of Tanzania grass will be dependent on operational and costs restrictions. Some of these data are in conflict with the updated literature and because of this it might be suggested a decision based on the overall control of losses from the forage harvesting stage through the animal performance. 


\section{INTRODUÇÃO}

Sabe-se que o Brasil possui um dos maiores rebanhos bovinos do mundo e imenso potencial para a produção pecuária. Em primeiro lugar é devido à sua extensão territorial e, em segundo, por apresentar condições climáticas favoráveis à produção de forragens de elevado potencial produtivo, em larga escala, não apresentando limitações com invernos rigorosos como os países temperados.

No entanto a cadeia produtiva bovina vem se arrastando a passos lentos movida pelo tradicionalismo e reduzido uso de tecnologia, gerando índices produtivos muito baixos.

Devido às novas barreiras sanitárias impostas, que fizeram com que países até então tradicionais na exportação de seus produtos de origem animal sofressem restrições, o Brasil tem a oportunidade de assumir a frente nas exportações, imprimindo ao sistema produtivo nacional um novo ritmo, obrigando o setor a assumir uma postura profissional, eficiente $\mathrm{e}$ internacionalmente competitiva.

Para isso, além de superar barreiras sanitárias, um grande passo na pecuária será mudar a visão quanto à produção de forragens, sendo as pastagens a base da pecuária nacional. Isso vem acontecendo recentemente com a substituição de gramíneas de baixo potencial produtivo e a intensificação da exploração das áreas remanescentes.

Apesar do Brasil oferecer condições propícias ao cultivo de plantas forrageiras de elevado potencial produtivo, não há como negligenciar o aspecto da sazonalidade, que atinge todas as espécies de gramíneas utilizadas. Em maior ou menor intensidade, as forrageiras apresentam elevada produção, 
concentrada na época chuvosa, com acentuada queda ou mesmo estagnação produtiva, no período seco do ano.

Inúmeros trabalhos de pesquisa têm demonstrado a influência da energia solar, temperatura e precipitação pluviométrica sobre a estacionalidade da produção forrageira em regiões tropicais, verificando-se, no geral, para as condições do Brasil Central, concentração de 70 a 80\% da produção no período de chuvas (verão) e de 20 a 30\% no período seco (inverno).

Conseqüentemente, o maior entrave ao avanço da produção de ruminantes em países tropicais é a falta de alimento volumoso de boa qualidade o ano todo, o que retarda o ciclo produtivo. Isso gera a necessidade de conservação de forragens para os períodos mais críticos, sem ter que recorrer ao estabelecimento de novas áreas com culturas para ensilagem, com milho, milheto ou sorgo, por exemplo.

Uma alternativa seria a de ensilar o excedente de forragem, de pastagens já existentes na propriedade, produzida durante o verão, quando não é consumida no mesmo ritmo de produção.

No entanto, ensilar capim não é colher o que resta da época das águas, mas sim planejar colhê-lo numa fase em que apresenta elevado valor nutritivo, antes de atingir a maturidade. Dessa forma, com o uso da silagem na seca integrado ao pastejo, é possível manter os dois sistemas intensificados o ano todo, com rebanhos relativamente estáveis, alimentados praticamente com forragem dos próprios sistemas.

Neste sentido, já existe por parte de alguns pecuaristas consenso de que o excedente da produção, ou mesmo a produção de uma área específica, podem ser armazenados constituindo-se numa reserva forrageira para épocas de escassez. Mas, embora a ensilagem se constitua em ferramenta mais vantajosa do que a confecção de feno em países tropicais úmidos, a produção de silagens não é prática comum entre os produtores rurais nos trópicos, gerando silagens com valor nutritivo considerado insatisfatório. 
A ensilagem de gramíneas enfrenta algumas dificuldades como, por exemplo, o elevado teor de umidade no momento ideal de corte, ineficiência dos sistemas de recolhimento e picagem dos equipamentos nacionais destinados para a colheita de forragem, etc. Como estes são alguns dos fatores básicos necessários para a ensilagem, vem se tentando superar estas e outras limitações ao processo de ensilagem de gramíneas através da pesquisa de melhores métodos.

Como exemplos de técnicas adotadas, no caso de excesso de umidade pode-se adicionar, no momento da ensilagem, grãos cereais moídos e polpa cítrica ou ainda optar pelo emurchecimento da forragem. Procedimento como redução no tamanho das partículas é outro método adotado na ensilagem e visa a melhor acomodação no silo e elevação da densidade da massa, favorecendo a fermentação. O uso de aditivos à base de microrganismos, ácidos ou enzimas favorecem a fermentação e permitem maior estabilidade da silagem. Estes processos podem adotados isoladamente ou podem ser combinados, conforme a necessidade.

Torna-se necessário superar os pontos críticos no processo de ensilagem de gramíneas, como um todo, visando a obtenção de maior eficiência, desde o momento da colheita, passando pela ensilagem até o momento do fornecimento no cocho aos animais, caso contrário a adoção desta técnica não será viável.

A conservação de forragens do excedente da pastagem visando a transferência para outra época do ano envolve custos elevados, sejam estes decorrentes da demanda de insumos e perdas físicas no processo (MS, valor nutritivo), ou de ambos, que devem ser avaliados em todo sistema.

Silagens de capins com qualidade inadequada limitarão o consumo e o desempenho do animal, assim, mais que obter alimento conservado disponível para os rebanhos, deve-se avaliar a relação custo:benefício do nutriente proveniente da silagem. 
O presente trabalho teve como objetivo avaliar os efeitos do teor de matéria seca, uso de inoculante bacteriano e alteração no tamanho de partículas sobre as propriedades químico-físicas de silagens de capim Tanzânia, as perdas durante o processo, os parâmetros nutricionais e o desempenho de bovinos de corte. 


\section{REVISÃO DE LITERATURA}

\subsection{Gramíneas do gênero Panicum maximum}

Nas últimas décadas grandes áreas de pastagens têm sido estabelecidas com novos cultivares de Panicum maximum, que vêm se adaptando bem às condições brasileiras e, como mostrado por Soares Filho \& Rodrigues (2001), com cortes a cada 35 dias na estação chuvosa e a cada 49 dias na estação seca, obtiveram produções de 11,75 t MS/ha nas águas e 2,09 t MS/ha na seca (15,10\% da produção anual). Neste mesmo estudo o capim Tanzânia foi apontado como uma das gramíneas com maior adaptabilidade às condições de cultivo impostas, baseado na sua produtividade e valor nutritivo.

Uma característica inerente às gramíneas tropicais, de modo geral, é que o avanço da maturidade faz aumentar sua produção de matéria seca, em detrimento de seu valor nutritivo (Lavezzo, 1985), exigindo acompanhamento para que seja utilizada de modo mais eficiente possível.

No verão, há rápido crescimento de folhas seguido pelo crescimento dos colmos e então da inflorescência. Acompanhando este aumento do teor de matéria seca há queda no teor de proteína e diminuição da digestibilidade, sendo que estes nutrientes ainda variam conforme relação folha:colmo (McDonald, 1981).

Apesar dessa queda no valor nutritivo, em muitos casos a vedação de pastagens no final do período das águas, para que seja consumida na época seca, consiste numa forma de reserva de forragem. O baixo valor nutritivo é amenizado com a adoção de suplementação protéica e/ou energética para suprir nutrientes que a forragem madura não mais fornece. 
No caso do capim Tanzânia, por apresentar hábito de crescimento cespitoso, a vedação por longos períodos ou manejo de pastejo inadequado, ocasiona elevada proporção de colmos, tornando-o inadequado à prática de pastejo diferido. Assim, um meio de aproveitar o excedente de forragem produzido na época das águas seria através do corte para ensilagem, enquanto seu valor nutritivo ainda é alto.

\subsection{Silagens de gramíneas tropicais}

Segundo Fahey \& Hussein (1999) a maior contribuição para a área de conservação de forragens, durante os últimos 40 anos, é atribuída ao nível de tecnologia de processamento e metodologia para evitar perdas de nutrientes, visando a melhoria da qualidade da silagem. Mais especificamente, com relação à ensilagem, os maiores feitos foram quanto ao desenvolvimento de aditivos (bacterianos, enzimáticos, ácidos, fontes de carboidratos), materiais para cobertura dos silos, métodos de colheita e picagem de forragem, desabastecimento e fornecimento da silagem.

Recentemente desenvolveram-se os sistemas de embalagens em fardos e silos tubulares revestidos por lona plástica. Tudo isso visando não somente tornar o processo mais eficiente economicamente, controlando pontos críticos, mas também a produzir um alimento de melhor qualidade para rebanhos cada vez mais exigentes.

Quando se fala em qualidade do processo de ensilagem refere-se ao padrão do processo fermentativo no silo, enquanto que o valor nutritivo da silagem vai depender, além do processo de conservação, da composição da forragem ensilada, uma vez que a ensilagem não melhora a qualidade nutricional da forragem original.

A eficácia do processo fermentativo pode ser avaliada pelos parâmetros $\mathrm{pH}$, ácidos orgânicos e nitrogênio amoniacal, dentre outros. $\mathrm{O} \mathrm{pH}$ ideal para forragens tradicionais deve estar entre 3,8 e 4,0 (McDonald et al., 
1991), embora isoladamente não possa ser considerado na avaliação da fermentação, pois seu efeito inibitório sobre bactérias depende da velocidade de declínio e do teor de umidade do ambiente. A maioria das enzimas que degradam proteína é ativa somente com pH acima de 5,0, de modo que a rápida acidificação do meio irá restringir a ação dessas enzimas, reduzindo perdas protéicas e melhorando a aceitação da silagem pelos animais.

A amônia também é usada como parâmetro na avaliação de silagens, e a extensão da degradação dos aminoácidos naquelas com baixo pH depende, principalmente, da intensidade de inibição de atividade clostrídica que pode ser relacionada com a taxa de produção de ácido lático e taxa de queda do pH.

Narciso Sobrinho et al. (1998) observaram em silagens de capim Elefante, com umidade original e emurchecidas, percentagens de ácido lático de 9,81 e $8,20 \%$ da MS, respectivamente. Para os mesmo tratamentos os autores observaram valores de nitrogênio amoniacal de 9,73 e 7,05\% do $\mathrm{N}$ total.

Benachio (1965), citado por Sobrinho et al. (1998), classifica silagens muito boas aquelas contendo de 0 a $10 \%$ de $\mathrm{N}$ amoniacal (\% $\mathrm{N}$ total), boas as que contêm de 10 a 15\%, aceitáveis aquelas com 15 a 20\% e ruins aquelas que apresentam acima de $20 \%$ de $\mathrm{N}$ amoniacal.

Silveira (1975) define uma boa silagem quando possui $\mathrm{pH}$ inferior a 4,2 e nitrogênio amoniacal até $8 \%$ do $\mathrm{N}$ total, valor de $\mathrm{pH}$ este ligeiramente superior ao citados por McDonald et al. (1991) como ideal.

Os ácidos acético, butírico e lático contribuem para a acidez final da massa armazenada, porém o ácido lático possui papel principal no processo fermentativo da silagem, sendo o maior responsável pela queda do $\mathrm{pH}$ a limiar abaixo do qual inibirá bactérias do gênero Clostridium (Vilela, 1998).

É desejável que bactérias do gênero Lactobacillus convertam açúcares em ácido lático promovendo rápida fermentação, exigindo para isso condições de anaerobiose no silo, caso contrário, quantidade insuficiente de ácido lático produzido não será capaz de prevenir a ação de bactérias indesejáveis. 
Como fatores limitantes à qualidade da silagem de capins tropicais estão o alto teor de umidade e baixo teor de carboidratos solúveis, que influenciam negativamente, impedindo rápido declínio do $\mathrm{pH}$. Após o corte da forragem há oxidação de açúcares, por respiração celular, atividade de enzimas oxidativas e microrganismos aeróbios. Quando a relação entre carboidratos solúveis e poder tampão diminui, um teor maior de matéria seca é requerido para evitar fermentações indesejáveis.

Se o teor de matéria seca for inferior a $21 \%$ e o de carboidratos solúveis for inferior a 2,2\% na base da matéria verde, bactérias produtoras de ácido butírico se desenvolverão utilizando lactatos e açúcares residuais, envolvendo a descarboxilação do ácido lático e diminuição da concentração hidrogeniônica. Essas condições são favoráveis aos Clostridium que passarão então a desdobrar aminoácidos, produzindo ácido butírico, ácidos voláteis, aminas, amônia e gases, piorando a qualidade da silagem (McDonald et al., 1991).

O excesso de umidade resulta em silagem de pior qualidade, não só devido às perdas dos princípios nutritivos via drenagem de efluente, como também pela formação de ácido butírico e intensa degradação de proteína. Neste sentido, o emurchecimento reduz perdas por efluentes além de inibir o crescimento de bactérias produtoras de ácido butírico, as quais são muito sensíveis à elevação da pressão osmótica (McDonald et al., 1991).

Procedimentos que favoreçam elevadas densidades da massa de forragem no silo são desejáveis pois minimizam perdas de matéria seca. A menor retenção de oxigênio na massa inibe fermentações indesejáveis e reduz os custos de estocagem por tonelada de matéria seca (Muck \& Holmes, 2000). A exclusão do ar é reconhecida como um dos mais importantes fatores que governam a produção de silagens de boa qualidade (Kearney \& Kennedy, 1962) e essa exclusão só é obtida em silagens bem compactadas, o que depende de intenso processamento mecânico . 
Altas concentrações de ácido lático são comuns em silagens não emurchecidas bem preservadas, enquanto que o ácido acético é muitas vezes o principal ácido de fermentação presente em silagens mal preservadas (Wright et al., 2000). Silagens de capins tropicais apresentam altas concentrações de ácido acético pela deficiência de bactérias produtoras de ácido lático (Vilela, 1998) e pelo baixo teor de açúcares na planta (Kearney \& Kennedy, 1962). Narciso Sobrinho et al. (1998) observaram teores de ácido acético em silagens de capim Elefante sem e com emurchecimento de 2,21 e 1,07 \% MS, respectivamente.

Panditharatne et al. (1986) observaram que as características de fermentação das gramíneas dos gêneros Panicum e Pennisetum, colhidas em diferentes estádios de crescimento, com ou sem aditivos, foram diferentes daquelas relatadas para silagens de forragens temperadas. $\mathrm{O} \mathrm{pH}$ das silagens esteve entre 4,8 e 5,9, acima daquele tido como convencional (3,8 a 4,2), demonstrando que a rota de fermentação em silagens de forragens tropicais difere daquela de forragens temperadas, sendo desconhecidos os fatores responsáveis pela preservação de forragens tropicais. Concluíram que o processo não está relacionado à produção de altas concentrações de ácido lático, sugerindo que o ácido acético, mais do que o ácido lático, seja o principal agente conservador em silagens de forragens tropicais.

Quando o teor de açúcares da planta está abaixo de um valor crítico (15\% na matéria seca e 3\% no material fresco, aproximadamente), a produção de ácido lático é limitada (Kearney \& Kennedy, 1962) e, como já exposto acima, gramíneas tropicais geralmente apresentam níveis de carboidratos solúveis abaixo dos níveis tido como ideais para o processo de ensilagem. Loures (2004) obteve em capim Tanzânia o teor de 5\% de carboidrato na MS, comprovando isso.

A menor concentração de carboidratos pode ser uma característica própria da planta, ou ser resultante de perdas por respiração em silagens emurchecidas ou acondicionadas de modo incorreto. Neste caso haveria 
necessidade de se estabelecer condições anaeróbicas imediatamente após o enchimento e compactação do silo (Kearney \& Kennedy, 1962), uma vez que os açúcares não são prontamente disponíveis como substrato para fermentação mas tornam-se disponíveis, eventualmente, como resultado da hidrólise realizada por enzimas presentes na planta, enzimas adicionadas ou hidrólise ácida (McDonald, 1981).

Outra possibilidade para tentar elevar a disponibilidade de carboidratos seria intensificar o processamento mecânico da forragem, rompendo grande número de células, visando a liberação de seu conteúdo celular, disponibilizando os açúcares solúveis para a ação microbiana. Mas esse procedimento pode ser prejudicial caso o teor de MS da forragem seja baixo, elevando a produção de efluente como conseqüência do rompimento celular intenso.

Segundo Kearney \& Kennedy (1962), até que todo oxigênio retido durante o enchimento do silo seja eliminado após seu fechamento, haverá decréscimo no teor de açúcares totais coincidindo com um período de aquecimento. Retardar o fechamento do silo ou manter muito oxigênio residual na massa é mais prejudicial para forragens com baixos teores de açúcares, pois através da respiração celular estes serão fermentados em condições aeróbias, não contribuindo significativamente para a produção de ácido lático.

Com a eliminação do oxigênio prevalece a anaerobiose, bactérias anaeróbias utilizam açúcares fermentáveis produzindo ácido lático, caso ainda exista carboidrato em quantidades suficientes para promover a queda do $\mathrm{pH}$, e com isso garantir a preservação da massa.

No entanto, McDonald (1981) verificou que, durante a ensilagem, a quantidade de ácidos produzidos pode ser maior que aquela prevista pela fermentação exclusiva de carboidratos, sugerindo que outras substâncias sirvam de substrato, sendo a hemicelulose o substrato mais provável de ser fermentado, devido à variação na sua concentração. 
Outro fator que pode atuar sobre o padrão de fermentação, e conseqüentemente na qualidade da fermentação, é o poder tampão, que é a capacidade ou habilidade da massa ensilada em resistir à variação do $\mathrm{pH}$. Como componentes tamponantes na forragem há sais de ácidos orgânicos (cítrico, por exemplo), ortofosfatos, sulfato e nitratos, e somente 10 a $20 \%$ são devidos à ação da proteína (McDonald, 1981).

Segundo Lavezzo (1985), com o envelhecimento da gramínea e/ou adoção de emurchecimento, ocorre redução na capacidade tamponante do capim.

Zierenberg et al. (2001) ensilando seis gramíneas tropicais observaram que todas apresentaram baixos teores de açúcares $(3,27 \%$ MS) e valores de poder tampão normais, conseqüentemente, a relação carboidrato solúvel/poder tampão permaneceu muito abaixo do valor considerado adequado $(3,0)$.

Esses mesmos autores, durante o teste de acidificação rápida, observaram que nenhuma das gramíneas avaliadas sem aditivos alcançou o $\mathrm{pH}$ de 3,6, dentro de 22 horas, que seria o aceitável para inibir microrganismos indesejáveis. Adicionando inoculante contendo bactérias homoláticas houve efeito positivo na queda do $\mathrm{pH}$, embora ainda insatisfatório, obviamente devido à baixa concentração de carboidratos solúveis que seriam substrato para acidificação. Quando houve adição exclusiva de sacarose ocorreu efetiva redução do pH, mas também ainda abaixo do aceitável, sugerindo, portanto, que a adição conjunta de fonte de açúcares e inoculante com bactérias homoláticas poderia auxiliar o processo (Zierenberg et al., 2001).

Como já foram abordados os fatores limitantes ao processo de ensilagem de gramíneas tropicais, em seguida serão apresentadas, de maneira mais detalhada, algumas estratégias que podem ser adotadas no processo de ensilagem com a intenção de tornar o processo mais eficiente e gerar silagens de melhor qualidade.

Geralmente caracteriza-se a silagem quanto à sua qualidade atribuindo-se valores aos seus teores de ácidos, umidade, amônia, pH, etc. No 
entanto mais importante que um ou dois fatores apresentarem valores ideais é que todos estejam conjuntamente próximos a valores aceitáveis, resultando em silagem de qualidade aceitável.

\subsection{Teor de matéria seca}

Como já mencionado acima, o excesso de umidade figura dentre os fatores mais limitantes à obtenção de silagens de gramíneas de boa qualidade, tornando o seu controle na ensilagem de fundamental importância para o processo.

Se o teor de matéria seca for inferior a 30\% deverá ocorrer aumento nas perdas na forma de efluente e maior probabilidade de fermentações por clostrídios, resultando em alimento de baixa aceitabilidade. A solução ideal seria abaixar o $\mathrm{pH}$ a ponto de inibir a presença de clostrídios, mas esta queda no $\mathrm{pH}$ depende de muitos fatores como tipo de forragem, teor de matéria seca na ensilagem, teor de açúcar e poder tampão (Muck \& Shinners, 2001).

Nussio et al. (2001) observaram que ao elevar o teor de matéria seca de Tifton (Cynodon dactylon) os valores finais de $\mathrm{pH}$ foram aumentados, sendo a queda no $\mathrm{pH}$ mais rápida com o uso de aditivo bacteriano. No entanto, até 12 horas após a ensilagem houve elevação no valor de $\mathrm{pH}$, devido à atividade de proteases, levando ao surgimento de amônia, antes que se iniciasse a produção de ácidos da fermentação.

Lavezzo (1985) ao elevar os teores de matéria seca de capim Elefante verificou comportamento inverso, com progressiva queda no $\mathrm{pH}$, além de diminuição nos teores de ácidos acético e butírico, caracterizando fermentações mais adequadas. Também Narciso Sobrinho et al. (1998) diminuiu a concentração de ácido acético com o emurchecimento de capim Elefante $(2,21$ vs $1,07 \% \mathrm{MS}$ ) mas no caso do ácido butírico o emurchecimento promoveu efeito contrário, elevando seu teor. 
O emurchecimento da gramínea na ensilagem tem sido largamente adotado como um meio de melhorar a qualidade de fermentação da silagem e reduzir a produção de efluente (Dawson et al., 1999), reduzindo assim seu potencial poluente e perdas de nutrientes por lixiviação.

No entanto, assim como observado por Nussio et al. (2001), esta técnica eleva o valor de $\mathrm{pH}$ da silagem que tende a apresentar maiores concentrações de amônia e menores concentrações de produtos de fermentação como ácidos butírico, acético, lático e etanol, indicando fermentação mais restrita (Dawson et al., 1999). Pois é sabido que em meio com menor teor de umidade as condições não são muito favoráveis ao desenvolvimento microbiano.

Condições climáticas prevalecentes durante o emurchecimento interferem no processo alterando a composição do produto final. Altas temperaturas associadas à maior velocidade dos ventos determinam menor tempo de exposição da forragem para a desidratação, melhorando a qualidade da silagem obtida (Dawson et al., 1999).

O emurchecimento poderá aumentar a intensidade de proteólise se o tempo estiver úmido, produzindo aminoácidos livres, peptídeos e aminas. Ocorrendo após a ensilagem, a proteólise vai gerar aminoácidos e amônia, podendo ser minimizada se houver rápida queda de $\mathrm{pH}$ (McDonald, 1981).

Como desvantagens práticas, o emurchecimento favorece perdas respiratórias, eleva o risco de perdas por precipitação e também perdas mecânicas no recolhimento, além de favorecer a elevação da temperatura dentro do silo (Muck \& Shinners, 2001).

Outro inconveniente é que a adoção do emurchecimento demandará mais mão de obra e combustível tornando questionável a economicidade dessas silagens (Lavezzo, 1985), devido à exigência de uma operação extra de recolhimento.

Também a forragem emurchecida requer atenção extra quanto à sua acomodação e vedação, pois apesar do emurchecimento elevar a densidade de 
matéria seca (Muck \& Holmes, 2000), em contrapartida, pode diminuir a densidade da massa ensilada em $15 \%$ e a concentração de ácido lático em 19\%, conforme obtido por Marsh (1979) e Narciso Sobrinho et al. (1998a), aumentando as perdas respiratórias (Muck \& Shinners, 2001).

Quanto às alterações orgânicas devido ao emurchecimento, além da perda de água, a maior delas é a redução no teor de carboidrato não estrutural pela respiração dos açúcares liberados. Como o pré-requisito para o início da fermentação anaeróbia primária é a liberação de suco intracelular, se os teores de matéria seca estiverem acima de 33\%, devido emurchecimento intenso, podem atrasar a fermentação e até evitar que ela ocorra (Marsh, 1979).

Vilela et al. (2001) descreveram diminuição no teor de carboidratos com o aumento do tempo de emurchecimento do capim Elefante, além de redução na produção de amônia devido à menor atividade dos clostrídios. O emurchecimento por 12 horas diminuiu a digestibilidade in vitro da matéria seca, explicada pela diminuição da fração FDN e aumento da FDA com emurchecimento mais longo, não sendo recomendada pelos autores como meio de melhorar a qualidade da silagem.

Outra desvantagem da prática do emurchecimento é a comum contaminação com solo durante o recolhimento da forragem, fazendo elevar seu teor de cinzas. Além desta causa Crestana et al. (2001) sugeriram que o maior teor de matéria mineral pode também ser devido ao efeito de lixiviação de minerais drenados pelo efluente em silagem sem emurchecimento, associado ao fato de que a respiração de carboidratos durante a confecção da silagem emurchecida proporcionalmente aumenta a fração mineral.

Castro et al. (2001a) comparando teores de matéria seca, com ou sem aditivo enzimático-bacteriano, em silagens de capim Tifton, observaram que a elevação progressiva no teor de matéria seca e no $\mathrm{pH}$ diminuiu a atividade de água e as contagens de bactérias anaeróbias, aeróbias e enterobactérias, concluindo que o incremento no teor de matéria seca restringe o crescimento bacteriano pela redução na água disponível. 
Em silagens de Tifton inoculadas Castro et al. (2001b) verificaram que a queda no $\mathrm{pH}$ foi mais rápida atingindo menores valores. Queda nos valores de condutividade elétrica e aumento na atividade de água, com o uso do inoculante, sugerem rompimento da membrana celular com extravasamento do conteúdo disponibilizando substrato para o crescimento de microrganismos, responsável pela acentuada queda no $\mathrm{pH}$.

Considerando as limitações operacionais ligadas ao emurchecimento, uma alternativa na redução do teor de umidade da massa na ensilagem é a adição de material absorvente, que pode ser grãos cereais finamente moídos, polpa cítrica ou outros. Este procedimento pode ser adotado desde que o teor de matéria seca final não seja muito elevado a ponto de dificultar a compactação e expulsão do ar. O aditivo, além de elevar o teor de matéria seca, não pode ser muito pobre nutricionalmente a ponto de prejudicar o valor nutritivo da silagem final.

Evangelista et al. (2001) observaram que a adição de farelo de trigo ou polpa cítrica desidratada, embora tenha elevado o teor de matéria seca do capim do gênero Cynodon spp (Coastcross), comprometeu as características fermentativas das silagens, não trazendo benefícios, independente da idade fisiológica, o mesmo ocorrendo com a adição de sacharina e fubá, utilizados por Lima et al. (2001).

No caso da polpa cítrica, além de elevar o teor de matéria seca também eleva os teores de carboidratos favorecendo a fermentação lática. Pedreira et al. (2001) observaram que com esta adição diminuiu o teor de amônia, de 11,8 para 4,7, e, apesar de não ter havido alterações no pH $(5,32$ em média), houve baixa proteólise devido provavelmente à reduzida atividade de clostrídios. Mesmo tendo utilizado uma forragem com elevado teor de matéria seca (38\%) o emurchecimento e a adição de polpa permitiram melhor conservação das silagens de Tifton 85.

Aguiar et al. (2001) obtiveram com o emurchecimento o mesmo efeito da adição de polpa, ao procurar reduzir a umidade, preservando a fração 
protéica em silagem de capim Tanzânia. Através da redução na umidade houve desencorajamento da ação de clostrídios pela elevação na pressão osmótica.

Igarasi (2002) adicionando polpa cítrica à forragem de capim Tanzânia, no verão, conseguiu além de reduzir o pH $(5,26$ vs 3,94), reduzir o teor nitrogênio amoniacal $(20,78$ vs $5,7 \% N$ total), produção de efluente (52 vs 30 kg.t forragem $\left.{ }^{-1}\right)$, produção de gases ( 7,25 vs $\left.2,88 \% \mathrm{MS}\right)$, conseqüentemente aumentando a recuperação de matéria seca (88 vs 95\%).

Quanto às frações fibrosas é de se esperar que seja reduzida com a adição de polpa cítrica ou outro ingrediente amiláceo, como material absorvente, pelo efeito da diluição (Crestana et al., 2001).

Ávila et al. (2003a, b) adicionando polpa cítrica, farelo de trigo ou fubá de milho, observaram que somente a polpa cítrica colaborou para aumento no teor de carboidratos solúveis e que os demais aditivos, embora não tenham contribuído para isto, melhoraram as características de fermentação devido à elevação na pressão osmótica pelo aumento no teor de matéria seca da mistura, inibindo crescimento de clostrídios, assemelhando-se aos relatos de Pedreira et al. (2001).

\subsection{Tamanho de partículas}

Além da redução no teor de umidade como meio de favorecer o processo de ensilagem, a redução no tamanho de partículas é outro procedimento adotado, objetivando aumentar a densidade da massa ensilada. A melhor acomodação da forragem e expulsão do ar gera rápida anaerobiose favorecendo a fermentação.

Lavezzo (1985) relatou que a picagem da forragem em pedaços de $3 \mathrm{a}$ $5 \mathrm{~cm}$ facilita a compactação e, conseqüentemente, expulsão do ar da massa ensilada, fato este também observado por Igarasi (2002) que reduzindo o tamanho de partícula de capim Tanzânia, ensilado no verão, aumentou a densidade de 599 para $687 \mathrm{~kg} \cdot \mathrm{m}^{-3}$. 
Apesar da redução no tamanho de partículas objetivar o aumento da densidade da massa ensilada, Muck \& Holmes (2000) anteriormente haviam observado comportamento inverso. A densidade final depende, além do tamanho de partículas, de fatores como a espessura da camada de forragem colocada no silo, tempo de compactação de cada camada e velocidade de enchimento.

Aguiar et al. (2001) ao adotarem diferentes tamanhos de partículas observaram que com sua redução houve efeito benéfico na conservação da fração protéica, demonstrado pela menor conversão da fração nitrogenada em nitrogênio não protéico. Os teores de PB em silagens com partículas menores e maiores foram de $11,76 \%$ e $10,69 \%$, respectivamente.

Com a redução no tamanho de partícula de gramíneas tropicais (Panicum e Pennisetum), de 7,5 a $15 \mathrm{~cm}$ para $1,5 \mathrm{~cm}$, Panditharatne et al. (1986) obtiveram pequena diminuição no pH $(5,4$ vs 5,2), maior preservação do carboidrato solúvel $(5,5$ vs 2,95$)$ e maior concentração de ácido acético (3,87 vs 5,43\% MS). O ácido propiônico apresentou maior concentração em tratamentos com partícula de $15 \mathrm{~cm}(5,18 \% \mathrm{MS})$ do que nas silagens com partículas menores $(2,24 \% \mathrm{MS})$. A aeração na massa determina o padrão de fermentação inicial e o perfil de ácidos, amônia, etc.

Gordon et al. (1958) observaram que com a picagem mais fina da forragem, a qualidade da silagem produzida foi melhorada, apesar da extensão de exclusão do ar e densidade terem sido constantes, o que contraria as conclusões de muitos autores. Como já exposto acima, a redução no tamanho de partícula pode não alterar a densidade da silagem dependendo da intensidade da compactação exercida.

O processamento mecânico mais intenso pode reduzir perdas por gases, favorecendo aumento de perdas por efluente, como concluído por Gordon et al. (1958) e Aguiar et al. (2000), em silagem de capim Tanzânia, gerando um questionamento sobre a intensidade de processamento mecânico. 
Além do tamanho de partícula interferir no processo fermentativo dentro do silo, Loures et al. (2003c) associaram a melhor estabilidade aeróbia com menores tamanhos de partículas de capim Tanzânia, sugerindo que a extensão desse efeito prolonga-se até o fornecimento da silagem aos animais.

\subsection{Inoculantes bacterianos}

Além do controle do teor de umidade e adoção de processamento mecânico mais intenso visando a criação de melhores condições para a fermentação dentro do silo, os aditivos bacterianos surgiram como forma de tentar direcionar a fermentação dentro do silo para um perfil de ácidos mais desejáveis.

Os inoculantes bacterianos abrangem hoje a classe de aditivos com mais rápido desenvolvimento em todo o mundo. A maioria dos inoculantes comerciais de silagens contêm culturas vivas de Lactobacillus plantarum e outras espécies de Lactobacillus, Pediococcus ou Streptococcus, sendo o Lactobacillus plantarum e/ou Streptococcus as espécies predominantes.

Para o inoculante, tão importante quanto a cepa é o número de bactérias presentes. A eficiência do inoculante depende da contagem de bactérias existentes na cultura, do poder tampão do meio e da quantidade e qualidade dos microrganismos adicionados (Muck \& Kung Jr., 1997; Vilela, 1998). Estes microrganismos são usualmente encontrados nas forragens e silagens, e têm sido selecionados por crescerem rapidamente sob condições abrangentes de temperatura e umidade, produzindo principalmente ácido lático, desde que haja substrato disponível.

Bactérias de ocorrência natural na forragem produzem outros produtos além do ácido lático, como ácido acético, amônia e etanol. Bactérias adicionadas via inoculante, produzem preferencialmente ácido lático que, sendo mais forte do que o ácido acético, derruba o valor do $\mathrm{pH}$ final, paralisando rapidamente a atividade de enzimas das plantas que degradariam a proteína. 
Além de reduzir a produção de etanol e nitrogênio amoniacal, as bactérias homoláticas dominam a flora epifítica, resultando em processo homofermentativo mais eficiente (Kung Jr \& Ranjit, 2001; Winters et al., 2001).

Preconiza-se que em silagens inoculadas há maior recuperação da matéria seca e elevação de sua digestibilidade e, o baixo $\mathrm{pH}$, diminui a população de microrganismos que produzem altos níveis de ácidos butírico e acético (Muck \& Kung Jr., 1997; Winters et al., 2001).

Apesar das vantagens expostas, o inoculante bacteriano pode ter efeito negativo na estabilidade aeróbia (aquecimento após contato com o ar) o que diminui a vida útil da silagem no cocho. O que vai determinar isto é o $\mathrm{pH}$ da silagem e seu teor de açúcares residuais, ou outros produtos que sirvam de substrato aos microrganismos aeróbios.

Embora o ácido lático proporcione menor $\mathrm{pH}$, o ácido acético é mais inibitório contra fungos e leveduras que causam o aquecimento e deterioração da silagem pós-abertura do silo (Muck \& Kung Jr., 1997). Deste modo, a estabilidade aeróbia é melhorada em alguns casos, mas piorada em outros (Muck \& Shinners, 2001), explicado pelo fato da haver competição dos microrganismos do inoculante com a flora natural da forragem ensilada (Muck \& Kung Jr., 1997; Muck \& Shinners, 2001).

Somente em anaerobiose é que bactérias homoláticas predominam e são eficientes, no entanto, em condições aeróbias e com substrato disponível as bactérias epifíticas podem dominar e consumir os carboidratos que serviriam de substrato às homoláticas (McDonald, 1981).

Clavero (2001) utilizando bactérias homoláticas em silagem de capim Elefante não conseguiu reduzir o pH $(4,11)$ em relação ao tratamento controle $(4,91)$, embora tenha conseguido elevar o teor dos ácidos lático $(16,7$ vs $4,6 \%$ MS) e acético ( 9,7 vs $7,3 \%$ MS) e reduzir o teor de ácido propiônico (1,4 vs $4,2 \% \mathrm{MS})$.

Coan et al. (2001) avaliaram o efeito do inoculante enzimáticobacteriano, a composição química e a qualidade das silagens dos capins 
Tanzânia e Mombaça. O uso do inoculante não melhorou as características qualitativas, fermentativas e nutricionais das silagens, independentemente do cultivar e da idade de corte. Bergamaschine et al. (1998), trabalhando com capim Tanzânia, e Haigh (1998) também não preconizaram sua adoção.

Castro et al. (2001a) comparando teores de matéria seca em capim Tifton, com ou sem aditivo enzimático-bacteriano, observaram que o aditivo reduziu mais intensa e rapidamente $\mathrm{o} \mathrm{pH}$ das silagens $(5,63$ vs 5,77$)$, a condutividade elétrica $\left(0,84\right.$ vs $\left.0,93 \mathrm{mS} . \mathrm{cm}^{-1}\right)$ e a contagem de organismos anaeróbios; mas houve aumento nos valores de atividade de água, contagem de microrganismos aeróbios e enterobactérias. Com a elevação no teor de matéria seca e $\mathrm{pH}$ houve decréscimo na atividade de água e contagem de anaero, aero e enterobactérias, devido à falta de água disponível, o que inibe o crescimento bacteriano.

Dawson et al. (1999) comparando silagens de azevém (Lolium), concluíram que com adição de ácido fórmico houve menor concentração de ácido lático, maior pH e maior concentração de carboidratos solúveis do que em silagens tratadas com inoculante bacteriano, indicando fermentação restrita em silagens tratadas com ácido fórmico, mais do que com inoculante.

O efeito do inoculante nas características de fermentação da silagem, em particular sobre o $\mathrm{pH}$, variam de acordo com as condições da planta na ensilagem, principalmente no caso do emurchecido, onde os efeitos dos aditivos na fermentação podem ser influenciados por fatores como condições do tempo no dia do emurchecimento. Peixoto et al. (2003) relataram que o uso do inoculante permitiu a diminuição do $\mathrm{pH}(4,20)$ em silagens emurchecidas em relação à silagem sem inoculante $(4,68)$.

Segundo Vilela (1998) fatores como espécie forrageira, composição química, teor de umidade e de carboidratos solúveis interferem na eficiência do inoculante. A origem das bactérias homoláticas também influenciam, pois um inoculante desenvolvido para uma forrageira pode ou não ser eficiente em 
outra. Geralmente os inoculantes têm apresentado mais efeitos positivos em silagens de capins do que nas de milho.

Embora os inoculantes possam contribuir para melhorar a qualidade das silagens, as respostas ao uso destes inoculantes não têm sido consistentes. Quando as técnicas de ensilagem, como picagem fina da forragem, compactação e vedação são adotadas adequadamente, o uso de inoculantes oferece poucas vantagens (Vilela, 1998). Além disso, nem sempre seus benefícios se estendem até ao animal traduzindo-se em melhor desempenho (Muck \& Shinners, 2001).

\subsection{Perdas no processo de ensilagem: do campo ao cocho}

As perdas durante a ensilagem iniciam-se no campo e se estendem até o cocho. No entanto, apesar de muitos procedimentos, como os acima discutidos, poderem ser adotados visando o aumento na eficiência do processo, inevitavelmente ocorrerão perdas.

Perdas na colheita relacionam-se à topografia do terreno, altura e estrutura das plantas e mecanismo de recolhimento e picagem da colhedora. Foi observado por Igarasi (2002) que as perdas no campo foram, no inverno, de $4,7 \%$ da MS total disponível com corte e recolhimento direto e $14,1 \%$ para 0 tratamento emurchecido e de $6,7 \%$ e $20,3 \%$, para os respectivos tratamentos, no verão.

A adoção do emurchecimento faz com que as perdas sejam elevadas pois a forragem é picada e lançada ao solo e após a desidratação será recolhida. No entanto, por mais uniforme que seja o terreno e o mecanismo de captação seja rebaixado, a eficiência de recolhimento será menor do que para a forragem que foi colhida com a umidade original.

Após a ensilagem outras características da planta serão responsáveis pelas perdas, como exemplo o baixo teor de carboidratos solúveis e elevado teor de umidade que podem ser danosos ao processo de fermentação e levar a 
perdas de matéria seca devido à ocorrência de fermentação secundária (Balsalobre et al., 2001b) e perda de nutrientes por lixiviação.

Segundo Jones \& Jones (1995), se a forragem possuir teor de matéria seca acima de $28 \%$ dificilmente ocorrerão perdas significativas por produção de efluente, que somente se elevam ao diminuir o teor de matéria seca da forragem. Sendo o efluente rico em compostos solúveis ( $N$, açúcares, produtos da fermentação), conseqüentemente resultará na perda de nutrientes digestíveis (Holmes \& Mathwes, 2001).

Loures et al. (2003c) obtiveram melhor estabilidade aeróbia de silagem de capim Tanzânia com o emurchecimento do que com o material ensilado sem emurchecimento. Este é um importante efeito na redução de perdas após abertura do silo e na qualidade durante o fornecimento aos animais, garantindo sua ingestão. Quanto maior o tempo entre a abertura e exposição do painel da silagem ao oxigênio e o aquecimento no cocho, maior será o tempo disponível para a ingestão.

O manejo do painel do silo é importante pois quanto menores forem as taxas de retiradas diárias maiores serão as perdas por deterioração devido maior tempo de exposição aeróbica. Mesmo que os tratamentos adotados na ensilagem tenham favorecido a preservação dentro do silo, após a sua abertura este efeitos podem ser anulados pela longa exposição aeróbia e não serem capazes de manter a silagem em boas condições.

Balsalobre et al. (2001b) observaram que a redução no tamanho de partículas contribuiu para diminuir a perda por gases de 20,36 para 13,61\% da MS, melhorou a fermentação, devido maior densidade e menor retenção de ar, resultando em menores valores de $\mathrm{pH}$. A produção de efluente foi diminuída pela adição de polpa cítrica, devido a seu poder absorvente. Ao reduzir tamanho de partícula esperava-se elevar a perda na forma de efluente mas com $10 \%$ de adição de polpa isso não ocorreu.

Em trabalho semelhante, Aguiar et al. (2000), também com silagem de capim Tanzânia, observaram que a adição de polpa reduziu as perdas por 
efluente, assim como as perdas totais. Porém, a redução no tamanho de partículas não foi efetiva na redução das perdas totais, pois embora tenha reduzido perdas por gases estimulou produção de efluente, fato também observado anteriormente por Gordon et al. (1958).

A redução do tamanho de partícula visa o aumento na densidade favorecendo a compactação. Usualmente o grau de compactação alcançado pela compressão mecânica é necessário para obter a exclusão do ar e estabelecer um meio anaeróbio no silo.

Enquanto alguns silos laboratoriais em pequena escala, como tubos de PVC ou baldes plásticos, têm indicado o efeito marcante da pressão aplicada sobre a produção de efluente, há evidências conflitantes para os efeitos de consolidação em grandes silos. Segundo Jones \& Jones (1995) a produção de efluente em silos grandes depende além da sua liberação através da massa ensilada também da subseqüente drenagem através dessa massa, de variadas densidades. Características de pressão e drenagem são difíceis, senão impossíveis, de se reproduzir em silos de pequena escala pois a material finamente picado tem aumentada sua produção de efluente, mas o inverso parece ocorrer em silos de grande escala indicando diferenças nas características de drenagem nos dois tipos de silos

Mesmo que em silos laboratoriais pequenos chegue-se a densidades semelhantes à de silos de grande escala, suas produções de efluente podem ser diferentes devido às pressões sobre eles exercidas durante a compactação e área sobre a qual essa pressão é exercida.

Quanto aos diferentes tipos de silos, Rony et al. (1984) compararam silos tipo torre e tipo bag e observaram que tanto para silagem de milho como para gramínea, no silo bag desenvolveu-se acelerado aumento na temperatura nos 10 primeiros dias de ensilagem, com nível máximo de temperatura de $43^{\circ} \mathrm{C}$ para silagem de gramínea e $24^{\circ}$ para silagem de milho. Após este aquecimento esfriaram rapidamente, associado com o efeito de convecção da temperatura ambiente. No caso do silo torre a temperatura máxima atingiu o pico com 15 
dias de ensilagem, com $44^{\circ} \mathrm{C}$ para gramínea e $24^{\circ}$ para o milho, com gradual queda da temperatura.

Estes autores ainda notaram perdas de matéria seca total maiores para silagem de gramínea $(9,25 \%)$ que para a do milho $(4,25 \%)$, relacionado com a alta temperatura de fermentação previamente observada para estes silos. Em parte, perdas elevadas se deve ao fato de que no silo bag o material não fica perfeitamente compactado como num silo torre, retendo mais ar na massa e promovendo respiração mais intensa. No entanto, para cada tipo de material não houve efeito de tipo de silo. No caso das gramíneas a perda foi de 9,5\% para silo tipo torre e de 9,0\% para silo tipo bag. Para silagens de milho as perdas nos silos tipo torre e tipo bag foram de 2,4 e 6,1\%, respectivamente.

Quanto ao uso de inoculante bacteriano, embora objetive melhorar a estabilidade aeróbia da silagem, em alguns casos isto não ocorre e até verificase o contrário. O ácido lático, tão desejável na manutenção da estabilidade da massa dentro do silo, além de não ser um agente antimicótico efetivo, pode ser usado como substrato para o crescimento por leveduras durante a exposição aeróbia. Kung Jr \& Ranjit (2001) comprovaram este efeito mostrando que a silagem inoculada apresentou sinais de deterioração em metade do tempo em relação àquela não inoculada.

Com a abertura do silo e o contato com o oxigênio, os microrganismos aeróbios se multiplicam e passam a dominar, levando a silagem à deterioração aeróbia, evidenciada pelo aquecimento da massa e aparecimento de fungos, ocasionando perdas visíveis de massa de silagem e perdas invisíveis de nutrientes.

Silagens mais propícias à deterioração aeróbia são aquelas com maior teor de carboidrato residual, por terem sido inoculadas ou intensivamente emurchecidas. Bactérias homoláticas presentes no inoculante são eficientes na fermentação e produzem ácido lático responsável pela rápida queda no pH, o que paralisa a ação de microrganismos indesejáveis, preservando as frações solúveis da silagem, dentre elas o carboidrato. 
No caso das silagens emurchecidas seu maior teor de carboidrato solúvel deve-se ao fato de que em material com maior teor de matéria seca, ou seja, próximo de $30 \%$, o requerimento de ácidos para abaixar o $\mathrm{pH}$ é menor e esta silagem estabiliza em valor de $\mathrm{pH}$ maior, poupando carboidrato da fermentação.

Após exposição ao ar há dois picos de aumento de temperatura, o primeiro, devido à ação de leveduras, ocorre em até três dias e o segundo pico, causado por fungos, ocorre após mais três ou quatro dias, utilizando-se de carboidratos, ácido lático e ácido acético como principais substratos. Então, o $\mathrm{pH}$ e a temperatura tendem a aumentar e perde-se matéria seca, além da degradação de aminoácidos gerar amônia, ajudando a elevar o pH (McDonald, 1981).

Um meio de reduzir perdas após abertura seria aumentar as taxas de retiradas do silo, que são determinadas pelo consumo diário e dimensionamento do silo (McDonald, 1981).

A preocupação em reduzir perdas deve estar presente em todas as etapas, desde o planejamento do tamanho do silo e procedimentos de colheita até o fornecimento para o animal.

\subsection{Fatores que interferem na resposta de animais}

\subsubsection{Aspectos da cinética ruminal e comportamento ingestivo}

A ingestão de matéria seca é afetada por fatores como enchimento físico do retículo rúmen, feed-back metabólico, aceitabilidade, etc, e cada teoria pode ser aplicada sob certas circunstâncias. Por exemplo, alimentos volumosos de baixa digestibilidade restringem a ingestão de matéria seca devido à lenta taxa de passagem, causando enchimento ruminal. Nesses casos o estiramento da parede ruminal faz com que receptores controlem a ingestão (NRC, 2001), constituindo-se numa limitação física. 
O método de conservação afeta mais o consumo do que a digestibilidade, pois subprodutos da fermentação (ácidos, amônia, etanol, etc) correlacionam-se negativamente com o consumo de silagem. Alguns aditivos ou procedimentos na ensilagem teriam o propósito de controlar a fermentação e estimular o consumo de silagem.

Quanto à composição do alimento, a fração FDA, com baixas taxas de digestão, é considerada o constituinte primário na dieta associado com o efeito do enchimento (NRC, 2001). Segundo Lavezzo (1985), valor nutritivo de uma silagem envolve fatores como consumo voluntário, digestibilidade e eficiência pelos quais os nutrientes são utilizados.

Como as forragens tropicais têm níveis elevados de fibra e baixos teores de conteúdo celular esses refletirão negativamente na sua digestibilidade e conseqüentemente na digestibilidade das suas silagens (Vilela, 1998).

McDonald (1981) complementa a idéia de que nos trópicos um fator que influencia na digestibilidade das forrageiras é a temperatura ambiente elevada que diminui a digestibilidade devido ao aumento da lignificação e aumento proporcional da parede celular da planta, em conseqüência da maior velocidade no metabolismo de açúcares.

Forragens que apresentam parede celular menos lignificada são desintegradas fisicamente mais facilmente pelos microrganismos ruminais, seguindo-se rápida produção de biomassa microbiana, devido à maior acessibilidade ao substrato para a fermentação (Van Bruchem et al., 1991).

Se a ingestão voluntária de matéria seca é limitada pelo enchimento ruminal, silagens mais digestíveis seriam ingeridas em maiores quantidades, existindo uma relação positiva entre estes dois fatores. No entanto, isto não foi o observado por Teller et al. (1993) que constataram que a silagem emurchecida, apesar de apresentar menor digestibilidade aparente da matéria orgânica (53,8 vs 60,0\%), foi ingerida em maiores quantidades (2,20\% PV ou $11,3 \mathrm{~kg}$ MS) do que silagem sem emurchecimento (1,87\% PV ou 9,6 kg MS). 
O enchimento ruminal reflete a taxa na qual a forragem é digerida, interferindo na ingestão voluntária. Entretanto, ao se medir cinética de degradação ruminal in situ foi observado por Teller et al. (1993) que em silagem emurchecida houve diminuição na taxa de degradação da matéria orgânica (8,5 vs $\left.6,6 \% \cdot h^{-1}\right)$, mas mesmo assim esta silagem apresentou maior ingestão (9,6 vs $\left.11,3 \% \cdot h^{-1}\right)$, indicando que a taxa de digestão ruminal não é o fator prevalecente no controle da ingestão de forragem.

Ao contrário, Loures et al. (2003b) puderam observar maior degradabilidade da matéria seca com o emurchecimento $\left(4,76\right.$ vs $\left.4,40 \% \cdot \mathrm{h}^{-1}\right)$ do capim Tanzânia, em relação ao não emurchecido, que apresentaram respectivamente os valores de 48,98 e 43,54\% de degradabilidade efetiva.

Embora a mastigação seja essencial na redução do tamanho de partículas em gramíneas, a degradação ruminal é um processo muito mais efetivo para a redução na sua espessura. Gramíneas tropicais têm duas características que contribuem na limitação da sua ingestão, a primeira é o maior conteúdo de parede celular e a outra é que folhas mais rígidas necessitam de tempo mais longo de desintegração no rúmen para reduzir seu tamanho de partícula do que plantas temperadas (Wilson et al., 1989).

Quanto à função da mastigação, e particularmente da ruminação, seria expelir o ar que envolve a partícula tornando-a mais úmida e propensa à ação microbiana. No entanto tratamentos químicos e físicos da forragem na ensilagem não mudam a quantidade de ruminação requerida pelas forragens, assim como também não alteram a composição química e a digestão ruminal.

Resultados de Teller et al. (1993) indicam que grandes variações na ingestão de silagens de gramíneas podem ser devidas a tratamentos químicos ou físicos (emurchecimento ou picagem), embora estes não afetem marcantemente a composição da silagem e alterem muito pouco o tempo de ruminação. Quanto à redução no tamanho de partículas os ovinos são mais responsivos a uma picagem mais fina da forragem do que os bovinos. 
Rinne et al. (2002) notaram que em vacas leiteiras a ingestão voluntária de silagens é aumentada com a elevação da sua digestibilidade, assim o controle físico da ingestão de alimento parece desenvolver um importante papel no comportamento ingestivo.

A ingestão e a digestibilidade dependem das taxas de digestão, passagem de partículas e redução do tamanho de partículas no rúmen, divididas em partículas capazes de escapar do rúmen e aquelas que ficam retidas. A transferência de partículas de um estado para outro, ou seja sua capacidade de sair do rúmen ou não, é prolongado quando o animal é alimentado com silagens progressivamente mais maduras, contendo maiores teores de fibra (Rinne et al., 2002).

Em se tratando de ensilagem de forragens há uma relação negativa entre ingestão de matéria seca e dietas com alto teor de umidade, havendo diminuição da ingestão de matéria seca total com a elevação no teor de umidade da ração. Como a maioria dos alimentos úmidos são fermentados e há decréscimo da ingestão quando estes são adicionados na ração, então o efeito depressivo deve-se mais aos produtos da fermentação do que pela presença de água em si (NRC, 2001).

Apesar disso Van Bruchem et al. (1991), ao compararem feno e silagem emurchecida, notaram que a ingestão voluntária foi maior para silagem, apesar do tempo gasto com ruminação, número de ruminações por ciclos e o número de mastigação não diferirem significativamente. Com base na matéria seca a ruminação é menos intensa com a silagem mas na base de FDN ocorre o inverso. A ingestão voluntária relaciona-se negativamente com teor de FDN dos alimentos mas positivamente com a ruminação

\subsubsection{Desempenho de animais}

Finalmente, depois de se tentar superar os fatores limitantes à ensilagem de gramíneas tropicais é no desempenho animal que devem ser 
traduzidos os efeitos das técnicas adotadas, sendo este resultado no final da cadeia o que mais interessa.

Forragem ensilada com umidade original é mais intensivamente fermentada, resultando geralmente em menor pH e maiores concentrações de produtos da fermentação, especialmente ácido acético, responsabilizado por diminuir a aceitabilidade e a ingestão voluntária em comparação à silagem emurchecida. Apesar da observação de Teller et al. (1993) de que a silagem de maior umidade ter sido consumida mais rapidamente que a emurchecida, não existiram indícios de que o $\mathrm{pH}$ ou a aceitabilidade tenham sido restritivos à ingestão voluntária destas silagens por bovinos.

Há uma relação positiva entre baixo teor de matéria seca da gramínea na ensilagem e subseqüente desenvolvimento de fermentação clostrídica, resultando em silagem pobremente preservada que forçará a baixa ingestão pelos animais. Comparando-se esta silagem com a emurchecida, na qual a fermentação é controlada com maior sucesso, reconhece-se que a magnitude do aumento na ingestão pode ser atribuída ao aumento no teor de matéria seca e à melhor preservação, principalmente pela redução na concentração de nitrogênio amoniacal, no que concordam Lavezzo (1985) e Wright et al. (2000).

Segundo Dawson et al. (1999) a magnitude de resposta ao emurchecimento está intimamente relacionada com a taxa de secagem ao campo e o aumento no teor de matéria seca, mais do que às características de fermentação da silagem.

Narciso Sobrinho et al. (1998b) emurchecendo capim Elefante favoreceram a ingestão de matéria seca em ovinos, porém sem alterar a digestibilidade da matéria seca $(56,12 \%)$.

Marsh (1979) comparando 40 trabalhos sobre 0 efeito do emurchecimento na digestibilidade, excluindo outros efeitos como tratamento mecânico e aditivos, observou que somente em $25 \%$ dos casos houve o benefício do emurchecimento sobre a digestibilidade, com aumento na ingestão. 
Para Marsh (1979) a melhora na produção animal confirma que o aumento na ingestão de matéria seca de silagens emurchecidas supera a possível desvantagem de menores coeficientes de digestibilidade. Ao contrário, Wright et al. (2000) descreveram que nutrientes são perdidos durante o emurchecimento e que nem sempre a maior ingestão seria suficiente para compensar a perda de nutrientes e melhorar o desempenho dos animais.

Keady \& Mayne (2001) ao fornecerem silagens de azevém emurchecidas ou não, com ou sem inoculante, a vacas Holandesas, observaram grandes diferenças nas características de ingestão, fato atribuído às diferenças nas concentrações de matéria seca, mais uma vez tomado como importante fator controlador. Os autores observaram ingestão de $7,2 \mathrm{~kg}$ MS.animal.dia ${ }^{-1}$ com silagem sem inoculante e sem emurchecimento, de 8,6 kg para silagem com inoculante e sem emurchecimento e de 10,9 kg para silagem combinando emurchecimento e inoculante.

É importante observar que ao se avaliar a ingestão de matéria seca da silagem deve-se considerar que aumentando a participação de ingredientes concentrados na ração pode ocorrer redução na ingestão de matéria seca da silagem (Steen et al., 2002), devendo este fato ser levado em conta ao se comparar e avaliar silagens.

A taxa de secagem e o teor de matéria seca final são importantes fatores que determinam o efeito do emurchecimento sobre a ingestão de silagem (Dawson et al., 1999). Mesma conclusão obtida através da revisão apresentada por Wright et al. (2000) na qual avaliaram que a perda total de água, taxa de emurchecimento e concentração de nitrogênio amoniacal em material emurchecido foram as variáveis mais intimamente e positivamente correlacionadas ao aumento proporcional na ingestão como resultado do emurchecimento.

Dentre as variáveis citadas acima, a taxa de perda de água no campo durante o emurchecimento foi a variável que explicou a maior proporção de 
variação na ingestão de matéria seca em forragem emurchecida. Além de maior ingestão o emurchecido proporcionou melhor ganho de peso.

Os resultados quanto ao uso de inoculantes bacterianos são os mais variados, tanto na ingestão quanto no desempenho de animais (Dawson et al., 1999). Vilela (1998) apresentou que os resultados decorrentes do uso de inoculantes sobre o consumo, ganho de peso e produção de leite em todos os testes avaliados, representaram melhora da ordem de 2 a 4\%.

Haigh (1998) com o uso do inoculante elevou o ganho de peso de 0,58 kg.animal.dia ${ }^{-1}$ para $0,65 \mathrm{~kg}$.animal.dia ${ }^{-1}$, com a ingestão se elevando de 4,76 kg MS.animal.dia ${ }^{-1}$ para 5,02 kg MS.animal.dia ${ }^{-1}$.

Há trabalhos onde o efeito do inoculante é bem pronunciado, como no caso de Winters et al. (2001), que comparando silagens de azevém tratadas com inoculante bacteriano ou ácido fórmico observaram que, apesar de todas as silagens terem sido prontamente consumidas pelos animais, silagens tratadas com inoculante $\left(8,2 \mathrm{~kg} \cdot \mathrm{dia}^{-1}\right)$ e ácido fórmico $\left(8,4 \mathrm{~kg} \cdot \mathrm{dia}^{-1}\right)$ permitiram consumo de MS significativamente maior que a controle $\left(7,4 \mathrm{~kg} \cdot \mathrm{dia}^{-1}\right)$, conseqüentemente, os respectivos ganhos de peso foram 0,89; 0,94 e 0,67 kg.animal.dia ${ }^{-1}$, respectivamente. Atribuiu-se o melhor desempenho ao fato dos aditivos limitarem a degradação protéica da silagem, promovendo rápida queda no $\mathrm{pH}$ e inibindo a atividade enzimática.

Também Clavero (2001) utilizando bactéria homolática em silagem de capim Elefante não reduziu o pH $(4,11)$ em relação ao tratamento controle $(4,91)$ embora tenha proporcionado maior ingestão (3,16 vs 2,45 kg MS silagem.animal.dia $\left.{ }^{-1}\right)$ e ganho de peso $\left(0,73\right.$ vs $0,65 \mathrm{~kg}$.animal.dia $\left.{ }^{-1}\right)$. Muck \& Kung Jr. (1997) concluíram que, embora o inoculante não tenha promovido nenhum efeito em melhorar a estabilidade aeróbia e vida útil no cocho, melhorou em um terço dos estudos a digestibilidade da matéria seca.

Diante do exposto acima este trabalho procurou abordar os efeitos do teor de matéria seca, tamanho de partícula e uso de inoculante bacteriano tanto no processo fermentativo, como no controle das perdas e propriedades físicas 
das silagens, comportamento ingestivo, parâmetros ruminais, digestibilidade e desempenho animal. 


\section{EFEITO DO TEOR DE MATÉRIA SECA E DE INOCULANTE BACTERIANO SOBRE A COMPOSIÇÃO QUÍMICO-FÍSICA E O CONTROLE DAS PERDAS NA SILAGEM DE CAPIM TANZÂNIA}

\section{Resumo}

O presente trabalho teve por objetivo avaliar o efeito do teor de matéria seca e da adição de inoculante bacteriano sobre a fermentação da silagem e as perdas no processo de conservação do capim Tanzânia (Panicum maximum, Jacq. cv. Tanzânia). A forragem foi colhida aos 60 dias de crescimento vegetativo e armazenada durante 150 dias em silos experimentais (20 L), providos com válvula tipo Bunsen para escape de gases e dispositivo para drenagem do efluente produzido. A forragem fresca foi comparada com a emurchecida (6 horas) e com adição de milheto grão moído, ambas visando obter teor de $30 \%$ de MS nas silagens. O inoculante bacteriano (L. plantarum) foi aplicado antes da ensilagem visando o fornecimento de $10^{5} \mathrm{ufc} / \mathrm{g}$ forragem. O emurchecimento elevou as perdas de MS na colheita (0,87 vs a,47 t MS.ha. $\left.{ }^{1}\right)$. Os índices de recuperação de matéria seca, a produção de efluente e as perdas de MS por gases foram de 90,58\%; 53,66 kg.t MV ${ }^{-1}$ e 6,40\% da MS nas silagens não-emurchecidas, 93,62\%; 16,81 kg.t $\mathrm{MV}^{-1}$ e 4,97\% em silagens adicionadas com milheto grão e 92,19\%; 3,55 kg.t MV ${ }^{-1}$ e 6,16\% nas silagens emurchecidas, respectivamente. O teor de matéria seca influenciou a DMV, resultando em 346, 454 e $442 \mathrm{~kg} \cdot \mathrm{m}^{-3}$ nas silagens emurchecidas, adicionadas com milheto e com umidade original, respectivamente, sendo que para estes mesmos tratamentos as DMS foram respectivamente 105, 144 e $97 \mathrm{~kg} \cdot \mathrm{m}^{-3}$. O uso do inoculante bacteriano diminuiu o índice de recuperação de MS, não 
alterando o teor de PB e produção de amônia nas silagens e tendeu $(P=0,07)$ a reduzir perda na forma de gases (6,34 vs $5,34 \%$ da MS). A adição do milheto resultou em silagens com menores frações fibrosas (FDN, FDA, CEL e HEMI) pelo efeito de diluição. A adição de milheto destacou-se pela maior eficiência na elevação do teor de MS das silagens em comparação às silagens emurchecidas. Como os índices de recuperação de matéria seca não diferiram, pois perdas de gases e efluente foram inversamente proporcionais entre tratamentos, a opção pelos tratamentos vai depender da ponderação de fatores que facilite a operacionalidade e reduza os custos na confecção da silagem.

\section{EFFECTS OF DRY MATTER CONTENT AND BACTERIAL INOCULANT ON THE CHEMICAL-PHYSICAL COMPOSITION AND CONTROL OF LOSSES IN TANZANIA GRASS SILAGE}

\section{Summary}

The present trial aimed to study the effect of dry matter content and the addition of bacterial inoculant on the silage fermentation and conservation losses of Tanzania grass (Panicum maximum, Jacq. cv. Tanzânia). The forage was harvested at 60-d vegetative regrowth and stored during a 150-d period in lab silos (20L), provided with Bunsen type valve for gases and drainage device for effuent yield. Wet forage was compared to wilting (6 hours) and the addition of ground pearl millet grain, both to reach 30\% DM content in the silage. Bacterial inoculant (L. plantarum) was applied onto forage before ensiling to reach $10^{5} \mathrm{cfu} / \mathrm{g}$. The wilting resulted in higher DM harvesting losses ( $0.87 \mathrm{vs}$ $0.47 \mathrm{DM} \mathrm{t}^{-h^{-1}}{ }^{-1}$ in relation to the wet forage harvest. Dry matter recovery rates, effuent yield and DM gases losses were 90.58\%, 53.66 kg.t wet forage $\mathrm{e}^{-1}, 6.40 \%$ for the wet silages; 93.62\%, 16.81 kg.t wet forage ${ }^{-1}, 4.97 \%$ for millet added silages and $92.19 \%, 3.55$ kg.t wet forage $\mathrm{e}^{-1}, 6.16 \%$ for the wited silages, respectivelly. The silages dry matter content influenced wet bulk density 
resulting in 346, 454 and $442 \mathrm{~kg} \cdot \mathrm{m}^{-3}$ and the DM silo bulk density 105, 144 and $97 \mathrm{~kg} \cdot \mathrm{m}^{-3}$ for the wilted, millet added and wet silages, respectivelly. Bacterial inoculant led to a lower DM recovery rate, did not alter either crude protein content or the ammonia yield in the silages and showed a trend $(P=0.07)$ for inhibiting gases losses (6.34 vs 5.34\%DM). Pearl millet addition determined lower fiber content in the silages due to the dilution of forage fiber fractions (NDF, ADF, CEL and HEMI) and defined a better strategy for increasing the DM content in tropical grass silages compared to wilting. Considering the compensatory effects revealed by effluent and gases losses and the offsets in DM recovery rate, the adoption and field recomendation of strategies will be dependent on the operational and costs restrictions.

\subsection{Introdução}

O Brasil, caracteristicamente tropical, apresenta ótimas condições de temperatura e umidade que favorecem a produção de gramíneas forrageiras de elevado potencial produtivo.

Dentre elas vem se destacando as do gênero Panicum, tanto no estabelecimento de novas áreas como em substituição a algumas forrageiras de menor potencial produtivo, ou mesmo em sistemas mais intensificados como pastejo rotacionado.

Independente da espécie, as gramíneas são afetadas pela estacionalidade na produção, ou seja, elevadas temperaturas e precipitações no verão favorecem elevadas produções de forragem, mas no período seco do ano a produção é diminuída, e às vezes até estagnada (Lavezzo, 1985), fato esse muito conhecido dos pecuaristas.

Como as gramíneas do gênero Panicum apresentam hábito de crescimento cespitoso requerem bom manejo de pastejo para evitar o acúmulo de colmos e queda na qualidade nutricional. Por isso não seria recomendado 
fazer o diferimento da área com estes capins para pastejo no inverno, sendo a ensilagem do excedente no verão uma forma eficiente de aproveitar a forragem, colhendo-a em estádio com elevado valor nutritivo.

Apesar desta possibilidade, as gramíneas tropicais apresentam características que não são favoráveis à boa fermentação no silo, como excesso de umidade e baixo teor de carboidratos solúveis (Vilela, 1998). Sob estas condições as perdas são elevadas, sejam na forma de gases, efluente, deterioração ou degradação de nutrientes.

Devido a estes e outros fatores adversos, muito tem sido pesquisado a fim de superar as limitações encontradas, tornando o processo cada vez mais eficiente.

No caso do excesso de umidade isto pode ser contornado fazendo-se o emurchecimento da forragem picada antes da ensilagem (Dawson et al., 1999; Aguiar et al., 2001; Crestana et al., 2001; Vilela et al., 2001) ou adicionando-se polpa cítrica ou grãos cereais moídos (Evangelista et al., 2001; Lima et al., 2001; Pedreira et al., 2001, Igarasi, 2002; Ávila et al., 2003a, b), ambos visando a elevação no teor de matéria seca para cerca de 30\% no momento da ensilagem.

A segunda opção parece mais vantajosa, pois além de elevar o teor de matéria seca, fornece carboidratos na mistura, não coloca em risco o material que fica exposto ao tempo, como no caso do emurchecimento e, em uma única operação mecanizada, a forragem está colhida e picada.

Um outro recurso visando a melhora no processo fermentativo é a adoção de tamanho de partículas menores na picagem da forragem, o que facilita a compactação, permite maiores densidades no silo, melhora a fermentação e diminui as perdas (Lavezzo, 1985; Panditharatne et al., 1986; Igarasi, 2002).

Complementando estas técnicas, vem sendo muito adotado o uso de inoculante bacteriano. Esse aditivo acelera e direciona a fermentação para a produção mais eficiente de ácido lático, inibindo fermentações indesejáveis que 
deterioram a silagem, como a degradação protéica por clostridios (Muck \& Kung Jr, 1997; Kung Jr \& Ranjit, 2001; Winters et al., 2001).

Apesar de serem usados com o objetivo de melhorar a qualidade das silagens, alguns autores (Bergamaschine et al., 1998; Haigh, 1998; Coan et al., 2001) não terem verificado benefício com seu uso. Coan et al. (2001) observou valores praticamente idênticos em silagens com e sem inoculante para nitrogênio amoniacal, respectivamente de 5,7 e 5,5\% $\mathrm{N}$ total e $\mathrm{pH}$ de 4,8 para ambas. Portanto, há de se considerar o tipo de cultura, as condições de ensilagem e o tipo de inoculante utilizado.

O presente trabalho teve como objetivo avaliar como o teor de matéria seca, tamanho de partícula e adição de inoculante bacteriano afetam o processo fermentativo e as perdas ocorridas em silagens de capim Tanzânia.

\subsection{Material e Métodos}

\subsubsection{Local do experimento}

O experimento foi conduzido no Departamento de Zootecnia - Setor Ruminantes, USP/ESALQ, em Piracicaba (SP).

As análises foram realizadas no Laboratório de Bromatologia, pertencente ao mesmo Departamento.

\subsubsection{Silos experimentais}

Para a confecção dos silos experimentais (unidades experimentais), foram utilizados baldes plásticos, com capacidade para 20 litros e tampas próprias, com encaixe, para garantir vedação adequada. No fundo do balde foram colocados $2 \mathrm{~kg}$ de areia seca, protegida por uma tela plástica fina e sobre esta, duas camadas de tecido de algodão, evitando que a forragem entrasse 
em contato com a areia seca, permitindo que o efluente fosse drenado para a mesma, sendo quantificado posteriormente por diferença de peso.

$\mathrm{Na}$ tampa do balde (silo experimental) foi feito um furo com um vazador por onde passou-se uma mangueira de borracha formando uma válvula (tipo Bunsen) para escape dos gases produzidos durante o armazenamento.

As perdas de matéria seca, na forma de gases e efluente, devido ao processo fermentativo, foram quantificadas gravimetricamente após período de fechamento. O conjunto vazio, (balde + tampa + areia + pano + tela), foi pesado e posteriormente preenchido com a forragem.

\subsubsection{Espécie vegetal e tratamentos adotados}

A forragem Panicum maximum Jacq. cv Tanzânia foi colhida em 04 de março de 2001, aos 60 dias de rebrota, de uma área destinada à produção de forragem para ensilagem, estabelecida em solo tipo Latosolo Roxo Eutrófico.

Durante a colheita, a forragem foi submetida a tratamentos resultantes da combinação de três fatores:

Fator 1- Teor de matéria seca (TMS):

- umidade original (MO);

- emurchecido (FE);

- umidade original com adição de milheto grão moído (MI).

Estes dois últimos tinham como objetivo elevar o teor de MS da forragem a aproximadamente $30 \%$ no momento da ensilagem.

Fator 2 - Tamanho de partícula:

- partícula maior (PMA);

- partícula menor (PME). 
Fator 3 - Aplicação de inoculante bacteriano no momento da ensilagem:

- presença (C);

- ausência (S) de inoculante bacteriano.

\subsubsection{Colheita da forragem e avaliações no campo}

A colheita foi realizada com a colhedora de forragem marca SILTOMAC ${ }^{\circledR}$ modelo 775 , tracionada por trator. Antes de cada período de colheita o equipamento teve seu conjunto de facas afiado e o conjunto de contra-facas aproximado ou afastado a fim de respeitar os tamanhos de partículas (PME e PMA) estabelecidos para os tratamentos.

Antes do corte da forragem, foi realizada a estimativa de produção de forragem através do lançamento aleatório de quadrados de $1 \mathrm{~m}^{2}$ (Penati et al., 2001), em cada área destinada ao corte direto (MO) ou emurchecido (FE), e com partículas menores (PME) ou maiores (PMA). A forragem compreendida dentro de cada quadrado foi cortada e quantificada, uma amostra foi tomada para determinação do teor de matéria seca em laboratório (Silva, 1981) e, posteriormente, estimada a produção de matéria seca ( $\mathrm{MS}$. ha ${ }^{-1}$ ) na área.

O mesmo procedimento de uso dos quadrados foi realizado após a colheita da forragem, objetivando medir a eficiência da colheita mecânica, lançando-se o quadrado por seis vezes (Penati et al., 2001) na área para determinar perda de material ceifado mas não recolhido pela colhedora. Toda a forragem picada e deixada sobre o solo pela colhedora foi coletada manualmente, quantificada, uma amostra foi tomada para determinação do teor de matéria seca em laboratório (Silva, 1981) e posteriormente foram estimadas as perdas de matéria seca ( $\mathrm{MS}$. ha- ${ }^{-1}$ ). 


\subsubsection{Aplicação dos tratamentos}

a) Forragem com umidade original (MO)

Tratamentos com umidade original compreenderam a forragem oriunda do corte direto da forragem e subseqüente ensilagem.

b) Forragem emurchecida (FE)

Neste caso o procedimento foi o de ceifar a forragem por volta das 9 horas da manhã, quando o excesso de orvalho já havia se dissipado. A janela traseira da colhedora, que fica sobre as facas coletoras móveis, foi aberta de modo que a forragem ceifada não fosse enviada às facas do rotor $\mathrm{e}$ posteriormente à bica mas jogada para trás, sobre os resíduos das touceiras. A forragem permaneceu exposta ao sol por aproximadamente 6 horas para a desidratação. Ao final deste período foram feitos ajustes nas distâncias das contra-facas do rotor de modo que ao coletar a forragem emurchecida esta fosse picada respeitando os tratamentos de partículas impostos. O período de 6 horas de emurchecimento, a que foi submetida a forragem, foi adotado como suficiente para elevar o teor de matéria seca ao limiar desejável (Igarasi, 2002), ou seja, partir de forragem com teor médio de $20 \%$ de MS e chegar em torno de $30 \%$.

c) Adição de milheto grão moído (MI)

Nos tratamentos com adição de milheto grão moído este foi adicionado à forragem com umidade original imediatamente antes da ensilagem nos baldes, de modo que a mistura homogênea atingisse teor de matéria seca próximo aos tratamentos emurchecidos, em torno de 30\%. Como o teor de matéria seca da forragem pelo corte direto encontrava-se em torno de $20 \%$ no momento da ensilagem, para atingir $30 \%$ de MS foram adicionados aproximadamente $16 \mathrm{~kg}$ de milheto moído para cada $100 \mathrm{~kg}$ de forragem fresca. Quantificou-se a forragem e o milheto nas respectivas proporções, homogeneizando-os sobre uma lona plástica. O milheto utilizado apresentavase finamente moído. 
d) Aplicação de inoculante bacteriano

$\mathrm{O}$ inoculante bacteriano utilizado foi o $\mathrm{ECOSYL}^{\circledR}$ Silage Inoculant, da empresa Ecosyl ${ }^{\circledR}$ Products Ltda. (Registered in England No. 3155665), caracterizado como uma cepa de Lactobacillus plantarum, na forma de pó desidratado, com nível de garantia de 20 bilhões de UFC. ${ }^{-1}$ de produto. $O$ inoculante foi diluído em água destilada, aplicando-o uniformemente sobre a forragem e homogeneizando-a. Seguiu-se a diluição recomendada pelo fabricante visando alcançar $10^{5} \mathrm{UFC} / g$ forragem. Para evitar contaminação, foram ensilados, na seqüência, os tratamentos sem a adição de inoculante e os tratamentos designados com inoculante.

e) Tamanhos de partículas: estes tamanhos não foram prédeterminados, mas sim, obtidos através de ajustes nas amplitudes máxima e mínima permitidas pelas contra-facas da colhedora.

\subsubsection{Delineamento experimental}

O experimento foi realizado seguindo o delineamento inteiramente casualizado, com quatro repetições (silos experimentais), apresentando um total de 48 silos experimentais. Os tratamentos consistiram de um arranjo fatorial entre teor de matéria seca, tamanhos de partículas e inoculante bacteriano, $3 \times 2 \times 2$ gerando, portanto, 12 tratamentos.

\subsubsection{Procedimento de enchimento dos silos experimentais}

Pequenas camadas de forragem (aproximadamente $10 \mathrm{~cm}$ ) foram sendo acomodadas e compactadas com o pé dentro dos baldes, de modo que todos os silos experimentais do mesmo tratamento tivessem semelhança quanto à pressão exercida e densidade no fechamento, e que as diferenças atribuídas aos diferentes tratamentos físicos não fossem confundidas por diferentes pressões de compactação. 
Ao atingir o limite da borda superior, a tampa foi encaixada e vedada com fita plástica adesiva tentando-se evitar a entrada de ar. O balde cheio e finalizado foi então pesado e armazenado em local sombreado.

\subsubsection{Abertura dos silos experimentais}

Decorridos 150 dias do fechamento, os silos foram abertos seguindo a rotina descrita: pesagem do balde cheio fechado, pesagem da silagem, amostragem da silagem, pesagem do conjunto (balde+areia+tela+pano+tampa) vazio. Este período de fechamento foi mais do que suficiente para a estabilização dos processos fermentativos.

\subsubsection{Determinação das perdas por gases}

No momento da abertura o balde cheio e ainda fechado foi pesado e a diferença de peso observada neste momento, em relação ao peso computado na data de fechamento, correspondeu a perda de massa na forma de gases, conforme Equação 1 a seguir:

$G=\frac{(P f e-P a b)}{(M F f e \times M S f e)} \times 1000$

onde,

$\mathrm{G}=$ perda por gases (\% MS);

Pfe $=$ peso do balde cheio no fechamento $(\mathrm{kg})$;

$\mathrm{Pab}=$ peso do balde cheio na abertura $(\mathrm{kg})$;

$\mathrm{MFfe}=$ massa de forragem no fechamento $(\mathrm{kg})$;

MSfe = teor de matéria seca da forragem no fechamento (\% MS). 


\subsubsection{Determinação da produção de efluente}

Após retirar toda forragem do silo experimental, pesou-se o conjunto vazio (balde + areia + pano + tela + tampa) e, subtraindo-se deste o peso do conjunto antes da ensilagem, com a areia seca, permitiu a estimativa da produção de efluente, que foi drenado para o fundo, conforme Equação 2 abaixo:

$$
E=\frac{(P a b-P f e)}{M F f e} \times 1000
$$

onde:

$E$ = produção de efluente $\left(\mathrm{kg} \mathrm{t}^{-1}\right.$ massa verde);

$\mathrm{Pab}=$ peso do conjunto (balde+tampa+areia+pano+tela) vazio na abertura, (kg);

Pfe $=$ peso do conjunto (balde+tampa+areia+pano+tela) vazio no fechamento, $(\mathrm{kg})$;

$$
\text { MFfe }=\text { massa de forragem no fechamento }(\mathrm{kg}) \text {. }
$$

\subsubsection{Determinação do índice de recuperação de matéria seca}

Esta determinação foi obtida através da diferença de peso obtida pela pesagem da massa de forragem nos momentos da ensilagem e da abertura e seus respectivos teores de MS, calculando-se a recuperação de MS (RMS), pela Equação 3:

$$
R M S=\frac{(\text { MFab } \times \text { MSab })}{(\text { MFfe } \times \text { MSfe })} \times 100
$$


onde:

RMS = índice de recuperação de matéria seca (\%);

MFab = massa de forragem na abertura $(\mathrm{kg})$;

MSab = teor de matéria seca da forragem na abertura (\%);

MFfe $=$ massa de forragem no fechamento $(\mathrm{kg})$;

MSfe = teor de matéria seca da forragem no fechamento (\%).

\subsubsection{Amostragem da forragem na ensilagem e das silagens na abertura}

A forragem destinada a cada tratamento no momento da ensilagem foi amostrada, sendo coletadas amostras separadamente para análises de condutividade elétrica (CE); extrato aquoso, no qual seria realizada leitura de $\mathrm{pH}$, análises de carboidratos solúveis (CS), nitrogênio amoniacal $\left(\mathrm{N}-\mathrm{NH}_{3}\right)$ e poder tampão (PT); tamanho de partículas (PART) e análises bromatológicas de matéria seca (MS), cinzas (CZ), fibra insolúvel em detergente ácido (FDA), fibra insolúvel em detergente neutro (FDN), proteína bruta (PB), lignina (LIG), nitrogênio insolúvel em FDA (N-FDA) e por diferença estimadas as frações celulose (CEL) e hemicelulose (HEMI).

O mesmo procedimento de amostragem foi adotado na abertura dos baldes, após todo o material deteriorado ter sido retirado das bordas superiores dos silos experimentais e o material ter sido homogeneizado.

As amostras foram identificadas e congeladas em freezer $\left(-20^{\circ} \mathrm{C}\right)$, com exceção daquelas destinadas à análise de $\mathrm{CE}$, as quais foram apenas resfriadas e imediatamente analisadas a fim de evitar rompimento celular e alteração de resultado.

\subsubsection{Análises químico-bromatológicas das amostras coletadas}

Todas as amostras coletadas e congeladas, na ensilagem e abertura dos baldes, foram descongeladas, secas em estufa de ventilação forçada a $60^{\circ}$ 
C (Silva, 1981), por 72 horas, moídas em moinho tipo Wiley provido de peneira com orifícios de $1 \mathrm{~mm}$ de diâmetro.

Devido ao grande número de amostras geradas a determinação da composição químico-bromatológica da forragem e das silagens foi realizada utilizando-se o método de espectroscopia de reflectância de infravermenlho proximal (NIRS) (Shenk \& Westernhaus, 1991; Berzaghi et al., 1997; Mathison et al., 1999; Cozzolino et al., 2001), visando a redução no número de amostras e otimização tanto do tempo como dos custos de análises.

O material moído foi escaneado para obtenção dos espectros NIRS. O equipamento utilizado foi o espectrômetro modelo NIRS 5000 (NIRSystems ${ }^{\circledR}$, Silver Spring, MD, USA) acoplado a um microcomputador equipado com softwear WinISI II versão 6.2 (Intrasoft International, PA), com dois tipos de células de leitura para escanear as amostras: quando estas apresentavam quantidades suficientes, foi utilizada a célula modelo Transport quarter cup (código IH - 0379), caso contrário, utilizou-se a de modelo Micro sample cup (código $\mathrm{IH}$ - 0348).

As amostras foram escaneadas nesse equipamento obtendo leituras compreendidas entre os comprimentos de onda de 700 a $2100 \mathrm{~nm}$. Os espectros foram armazenados em curvas log, ( $1 / R$, onde $R$ é o valor da reflectância) em intervalo de $2 \mathrm{~nm}$. Utilizaram-se os métodos de seleção de amostras existentes no softwear do equipamento e foram descartadas as amostras distantes mais de $3 \mathrm{H}$ (distância padronizada de Mahalanobis) da média, e essas foram tidas como outliers. Adotou-se uma distância mínima de 0,6 H entre amostras, para seleção daquelas em que seriam efetuadas as análises bromatológicas convencionais, ou seja, onde o valor outlier $(\mathrm{H})$ é usado para eliminar amostras com distâncias espectrais muito afastadas da média da população (Shenk \& Westernhaus, 1991; Mathison et al., 1999).

O procedimento realizado pelo programa é o seguinte: as amostras para calibração foram selecionadas espectralmente usando o sub-programa ISI SELECT (Shenk \& Westernhaus, 1991), que começa identificando o espectro 
representativo de espectros vizinhos, mantendo este e descartando os semelhantes. Então, o programa avalia todas as amostras remanescentes e repete o procedimento até que reste o mínimo possível de amostras representativas do total. O procedimento SELECT usa uma distância H padronizada entre pares de amostras para definir vizinhanças, e baseia-se na suposição de que somente uma amostra seja requerida para representar todas as amostras contidas naquele grupo de vizinhança. Quanto mais heterogêneo for o grupo de amostras escaneadas maior deverá ser o número de amostras selecionadas para cobrir toda amplitude espectral ( Mathison et al., 1999).

Nas amostras selecionadas foram realizadas análises convencionais, ou métodos de referência (Berzaghi et al., 1997). Foi realizada análise do teor CZ (AOAC, 1980), análise do teor de PB, obtidas através da combustão das amostras segundo o método de Dumas, utilizando-se um auto-analisador de nitrogênio, marca LECO ${ }^{\circledR}$, modelo FP-528 (Wiles et al., 1998). Teores de fibra insolúvel em detergente neutro (FDN) foram obtidos através do método proposto pela ANKOM Fiber Analyser (ANKOM Technology Corporation, Fairport, NY). Os teores de fibra insolúvel em detergente ácido (FDA) e lignina (LIG) foram calculados segundo método de Van Soest et al. (1991). Análise de nitrogênio na fibra insolúvel em detergente ácido (N-FDA) foi realizada seguindo metodologia proposta por Krishnamoorthy et al. (1982).

Após análise química convencional os valores foram inseridos no banco de dados e permitiram ao softwear do programa NIRS predizer o valor das demais amostras não analisadas. Utilizou-se métodos estatísticos existentes no softwear do NIRS para o desenvolvimento de equações de predição dos teores dos componentes da análise químico-bromatólógica para o total de amostras.

A composição químico-bromatólógica das forragens no momento da ensilagem está apresentada na Tabela 1. 
Tabela 1. Composição químico-bromatológica das forragens no momento da ensilagem

\begin{tabular}{lcccccc}
\hline & \multicolumn{2}{c}{ Original } & \multicolumn{2}{c}{ Tratamentos } & \multicolumn{2}{c}{ Milheto } \\
Variáveis & Sem & Com & Sem & Com & Sem & Com \\
\hline Matéria Seca, \% & 19,7 & 20,8 & 28,4 & 28,6 & 29,2 & 29,1 \\
Cinzas \%MS & 11,4 & 11,4 & 10,8 & 11,0 & 9,1 & 8,3 \\
Proteína Bruta, \%MS & 8,5 & 8,2 & 8,0 & 8,5 & 10,7 & 11,7 \\
Fibra em detergente neutro \%MS & 69,4 & 70,3 & 71,7 & 71,4 & 51,5 & 51,4 \\
Fibra em detergente ácido, \%MS & 48,5 & 48,2 & 45,8 & 47,1 & 34,1 & 32,8 \\
Lignina, \%MS & 5,7 & 5,4 & 5,5 & 5,8 & 4,0 & 4,2 \\
Hemicelulose, \%MS & 21,9 & 23,1 & 25,7 & 24,8 & 18,8 & 19,1 \\
Celulose, \%MS & 41,7 & 41,9 & 40,4 & 40,8 & 29,8 & 28,7 \\
Nitrogênio insolúvel em FDA, \% N total & 16,4 & 15,9 & 18,9 & 18,7 & 16,3 & 16,0 \\
Carboidratos solúveis, \% MS & 5,8 & 3,6 & 2,6 & 3,1 & 3,9 & 2,8 \\
Condutividade Elétrica, mS.cm ${ }^{-1}$ & 1,3 & 1,4 & 1,3 & 1,6 & 1,3 & 1,4 \\
Tamanho médio de partícula, cm & 3,2 & 3,1 & 3,2 & 3,2 & 2,6 & 2,6 \\
Retenção na peneira superior, \% & 87,3 & 86,1 & 88,6 & 91,9 & 69,4 & 68,0 \\
pH & 6,1 & 6,1 & 6,3 & 6,5 & 5,2 & 5,3 \\
Poder Tampão, meq.100g MS ${ }^{-1}$ & 21,7 & 22,0 & 19,6 & 18,4 & 24,6 & 26,5 \\
\hline
\end{tabular}

${ }^{1}$ Com e Sem inoculante bacteriano. 


\subsubsection{Determinação da Condutividade elétrica (CE) das forragens e silagens}

O processamento mecânico da forragem faz com que as membranas celulares sejam rompidas e o conteúdo intracelular seja liberado, carregando íons. Este extravasamento pode ser maior ou menor, conforme o tamanho das partículas, ou seja, quanto menor o tamanho das partículas acredita-se que maior número de células sejam rompidas, liberando seu conteúdo intracelular, podendo-se assim, fazer a mensuração indireta da quantidade de eletrólitos dispersos em solução, quantificados através da CE. O procedimento adotado foi proposto por Kraus et al. (1997) e consistiu em agitar a forragem com água deionizada, filtragem e posterior leitura desta solução em um condutivímetro da marca DIGIMED ${ }^{\circledR}$ modelo CD 20, sendo os valores das leituras expressos em $\mathrm{mS} . \mathrm{cm}^{-1}$.

\subsubsection{Determinação do tamanho de partículas da forragem e das silagens}

Amostras descongeladas foram avaliadas para tamanho médio de partículas baseado na metodologia da estratificação em peneiras utilizando o PennState Particle Size Separator (Lammers et al., 1996), estimando-se o tamanho médio de partículas através da proporção de material que ficou retido em cada estrato, ou seja, acima de 1,89 cm, entre 1,89 e 0,78 e abaixo de 0,78 $\mathrm{cm}$. Embora tenham sido adotados tamanhos de partículas, explorando-se as amplitudes de corte (máxima e mínima) da colhedora, e esta diferença no tamanho médio de partículas da forragem (maior e menor) tenha sido visível, o método utilizado (Lammers et al., 1996) não foi sensível o suficiente para detectar esta diferença na forragem no momento da ensilagem.

$\mathrm{Na}$ forragem picada, antes da ensilagem, tratamentos com partículas denominadas maiores apresentaram retenção na peneira superior de $87 \%$ e 
partículas menores de $77 \%(\mathrm{P}=0,08)$, e seus tamanhos médios foram de 3,11 e $2,84 \mathrm{~cm}$, respectivamente $(P=0,08)$. Ou seja, a maior parte da forragem ficou retida na peneira superior $(1,89 \mathrm{~cm})$, podendo a diferença significativa entre os tamanhos de partículas (maiores e menores) residir acima desse limite. Esse fato foi comprovado posteriormente por Mari (2003) ao incluir uma peneira extra superior $(3,8 \mathrm{~cm})$, ao conjunto de peneiras proposto pela metodologia original (Lammers et al., 1996), à partir do que foi possível caracterizar melhor o tamanho médio de partículas da forragem em relação ao método original.

Dentre outros fatores que podem explicar a falta de resposta está a amplitude insuficiente no distanciamento das contra-facas ou ainda, a perda de afiação durante o trabalho, prejudicando os tratamentos colhidos por último.

Tratamentos adicionados com milheto grão moído apresentaram tamanho médio de partícula menor do que em forragens sem a adição do cereal, embora a forragem utilizada nesta mistura tenha sido a mesma, sendo o cereal o responsável pela redução no tamanho médio de partícula da mistura.

Ao abrir os baldes e realizar novamente o procedimento de estratificação por peneiras foi detectado que a retenção na peneira superior foi de $88 \%$ para as silagens com partículas maiores e de $82 \%$ para as partículas menores $(P<0,01)$, sendo os tamanhos médios de partículas de 4,25 e 4,04 cm, para partículas maiores e menores, respectivamente $(P<0,01)$.

Embora tenha havido diferença estatística, trata-se de diferença biologicamente pouco significativa. A diferença de $0,21 \mathrm{~cm}$ entre tamanhos de partículas pode ser considerada desprezível, mesmo porque em situações de colheita no campo é uma amplitude de variação que não tem como ser controlada levando-se em consideração os tipos de colhedoras disponíveis no mercado.

Ao se considerar o efeito de tamanho de partícula na análise das variáveis de interesse (parâmetros químicos e físicos) nas silagens, em muitos casos ocorreram interações entre os fatores. Ao desdobrar essas interações foi notado que onde ocorreram interações envolvendo partículas estas foram 
devidas à presença do milheto grão na silagem e não pela diferença no tamanho de partícula em si, causando um confundimento na interpretação.

Como a diferença no tamanho de partícula não foi detectada na forragem antes da ensilagem optou-se pela análise dos dados em conjunto excluindo-se os efeitos de tamanho de partículas e considerando aqueles referentes ao teor de matéria seca e uso de inoculante bacteriano.

\subsubsection{Extrato aquoso: pH, carboidratos solúveis, nitrogênio amoniacal e poder tampão}

Após as amostras de forragem e silagens terem sido descongeladas, preparou-se o extrato aquoso (Kung Jr. et al., 1984) utilizando-se $25 \mathrm{~g}$ de forragem fresca e $225 \mathrm{~mL}$ de água deionizada, as quais foram processadas em liqüidificador, por um minuto, obtendo-se o extrato aquoso no qual foi medido o valor de $\mathrm{pH}$ em potenciômetro digital DIGIMED - DM20 ${ }^{\circledR}$. Posteriormente, este extrato foi filtrado em papel de filtro Whatman ${ }^{\circledR} 54$, centrifugado e congelado para análises de carboidratos solúveis (Dubois et al., 1956) e nitrogênio amoniacal (Chaney \& Marbach, 1962).

O mesmo procedimento foi seguido, com uma outra amostra, para a obtenção do extrato no qual foi determinado o poder tampão (Playne \& McDonald, 1966). Análises de carboidratos solúveis (Dubois et al., 1956) com leitura em 490 nm e N-NH 3 (Chaney \& Marbach, 1962) com leitura em 550 nm, tiveram suas leituras realizadas em espectrofotômetro JENWAY-6405 UV/VIS ${ }^{\circledR}$.

\subsubsection{Análise estatística}

Os dados foram analisados utilizando-se o procedimento GLM do programa estatístico SAS ${ }^{\circledR}$ versão 6.12 para Windows ${ }^{\circledR}$ (SAS, 1996).

Para efeito de comparação de médias entre tratamentos foi utilizado o teste de média dos mínimos quadrados, LSMEANS, com nível de significância 
de 5\%. Quando necessária a exploração das tendências, a comparação foi acompanhada da declaração do nível de significância observado.

\subsection{Resultados e Discussão}

\subsubsection{Produção da área colhida e perdas no processo de colheita}

Antes da colheita a estimativa de produção de forragem, realizada através do lançamento aleatório de quadrados, demonstrou que não houve diferença $(P=0,85)$ na produtividade entre as áreas destinadas aos diferentes tratamentos, sendo a disponibilidade média de 15,95 t MS.ha ${ }^{-1}$.

Este valor está muito acima das 8,7 t $\mathrm{MS}$ ha $^{-1}$ obtidas por Igarasi (2002), mesmo sendo a forragem do presente trabalho colhida na mesma área 15 dias após período de crescimento vegetativo mencionado pelo referido autor. Este valor superior pode ser atribuído à uma fase de condições favoráveis ao crescimento resultando em elevada taxa de acúmulo de forragem ou a super estimativa causada por desvio no lançamento do quadrado, em pontos não representativos da área.

As perdas médias nas áreas destinadas à colheita de forragens emurchecidas e com umidade original foram de 0,87 e 0,47 t MS.ha-1, respectivamente, o que corresponde a 5,45 e 2,95\% de perdas em relação à forragem disponível $\left(15,95 \mathrm{t} \mathrm{MS}^{-h^{-1}}\right)$.

Os valores acima são inferiores aos 0,58 e 1,77 t MS.ha- ${ }^{-1}$, o que equivale a 6,7 e $20,3 \%$ de perdas em relação ao disponível, observados por Igarasi (2002), para capim Tanzânia submetido a tratamentos com umidade original e emurchecidos, respectivamente. Como a disponibilidade de forragem no presente estudo foi superior ao esperado, as perdas poderiam acompanhar a mesma tendência, fato que não ocorreu. 
Quanto à forragem emurchecida, que foi colhida, picada e lançada sobre o solo, as perdas avaliadas no recolhimento ressaltaram o efeito de teor de matéria seca $(P<0,01)$. Mesmo adotando uma altura mais baixa no recolhimento este não foi tão eficiente quanto à colheita da planta em pé, além de irregularidades no terreno não permitirem que esta coleta tenha sido uniforme em toda área. O conjunto de observações sugere que ao se adotar o emurchecimento seria conveniente questionar as perdas elevadas na captação de forragem a campo, bem como o risco por contaminação por solo.

Outros métodos visando a elevação no teor de matéria seca na ensilagem, como a adição de material absorvente, como cereais moídos na forma de fubá ou polpa cítrica, poderiam oferecer condições operacionais e econômicas mais vantajosas.

\subsubsection{Aspectos físicos das silagens}

Os resultados relativos aos aspectos físicos das silagens de capim Tanzânia, confeccionadas com as forragens submetidas a diferentes tratamentos, podem ser observados na Tabela 2 .

\subsubsection{Tamanho de partícula das silagens}

Resultados referentes ao tamanho médio de partículas, apresentados na Tabela 2, demonstram que houve efeito de teor de matéria seca $(P<0,01)$ mas não houve efeito do uso de inoculante bacteriano $(P=0,41)$ sobre essa variável.

Os tamanhos médios de partículas para os tratamentos emurchecidos, com adição de milheto e com umidade original foram 4,39; 3,67 e 4,37 cm, respectivamente, sendo que apenas tratamentos com milheto diferiram dos demais que não diferiram entre si. 
Tabela 2. Parâmetros físicos das silagens de capim Tanzânia submetidas aos efeitos do teor de matéria seca e uso de inoculante bacteriano na ensilagem

\begin{tabular}{|c|c|c|c|c|c|c|c|c|c|c|}
\hline \multirow[b]{3}{*}{ Variáveis } & \multicolumn{6}{|c|}{ Tratamentos } & \multirow[b]{3}{*}{$C V^{2}$} & \multirow{2}{*}{\multicolumn{3}{|c|}{ Efeitos ${ }^{1}$}} \\
\hline & \multicolumn{2}{|c|}{ Original } & \multicolumn{2}{|c|}{ Emurchecido } & \multicolumn{2}{|c|}{ Milheto } & & & & \\
\hline & $\mathrm{Sem}^{3}$ & Com & Sem & Com & Sem & Com & & 1 & 2 & 3 \\
\hline Condutividade Elétrica, ${\mathrm{mS} . \mathrm{cm}^{-1}}^{-}$ & 1,9 & 1,7 & 1,6 & 1,7 & 1,8 & 1,7 & 11,5 & * & & 0,3 \\
\hline Partícula, cm & 4,3 & 4,4 & 4,4 & 4,3 & 3,6 & 3,8 & 5,5 & ** & 0,4 & 0,3 \\
\hline Retenção na peneira superior, \% & 90,4 & 91,4 & 92,3 & 90,4 & 71,8 & 74,7 & 6,4 & ** & 0,7 & 0,5 \\
\hline Gás, \% MS & 6,7 & 6,1 & 6,7 & 5,6 & 5,7 & 4,3 & 31,9 & & & 0,8 \\
\hline Efluente, kg.t MV ${ }^{-1}$ & 52,9 & 54,4 & 4,1 & 3,0 & 19,0 & 14,6 & 41,0 & ** & 0,6 & 0,7 \\
\hline Recuperação de Matéria Seca, \% & 93,6 & 87,6 & 92,0 & 92,4 & 94,0 & 93,2 & 3,6 & * & * & * \\
\hline Densidade de Massa Verde, $\mathrm{kg} \cdot \mathrm{m}^{-3}$ & 436 & 447 & 339 & 354 & 463 & 446 & 7,4 & ** & 0,8 & 0,3 \\
\hline Densidade de Matéria Seca, $\mathrm{kg} \cdot \mathrm{m}^{-3}$ & 96,0 & 97,4 & 102,4 & 107,6 & 148,4 & 140,7 & 13,3 & ** & 0,9 & 0,5 \\
\hline
\end{tabular}

${ }^{1}$ efeitos: 1 = matéria seca (ms); 2 = inoculante (inoc); 3 = ms $\times$ inoc.

$2 \mathrm{CV}$ = coeficiente de variação.

${ }^{3}$ Com e Sem inoculante bacteriano.

** $P<0,01 ; * P<0,05 ; \quad P<0,10$. 
O efeito do teor de matéria seca sobre o tamanho de partícula ocorreu somente com silagens adicionadas com milheto, devido à participação do milheto grão finamente moído, que contribuiu para reduzir o tamanho médio de partícula da mistura, embora a forragem utilizada tenha sido picada no mesmo tamanho de partícula que as demais silagens sem milheto.

Quanto à retenção de silagem na peneira superior, durante estratificação, as silagens com umidade original, emurchecidas e com adição de milheto apresentaram valores de 90,9; 91,4 e 73,3\%, respectivamente, sendo que somente silagens adicionadas com milheto diferiram das demais, que não diferiram entre si.

Embora a colhedora não permitisse ajustes precisos quanto a tamanhos de partículas possibilitou que as partículas obtidas no presente trabalho se situassem entre 3 e $5 \mathrm{~cm}$, tamanho que segundo Lavezzo (1985) é suficiente para obter boa compactação e expulsão do ar.

A combinação entre tamanho de partícula e teor de MS da forragem interfere na densidade da massa ensilada. A redução no tamanho de partícula favorece a elevação da densidade enquanto que a elevação no teor de MS dificulta a acomodação da massa durante a compactação. Pode-se assim dizer que, à medida que eleva-se o teor de MS da forragem, pode-se reduzir tamanho de partícula, visando maior compactação da massa.

\subsubsection{Condutividade elétrica (CE) das silagens}

Resultados referentes aos valores de CE são apresentados na Tabela 2. Pode ser observado que houve efeito de teor de matéria seca $(P<0,05)$, apesar de não ter sido observado efeito para o uso de inoculante bacteriano $(P=0,10)$ sobre a condutividade elétrica.

Os valores médios de CE para os tratamentos emurchecidos, com

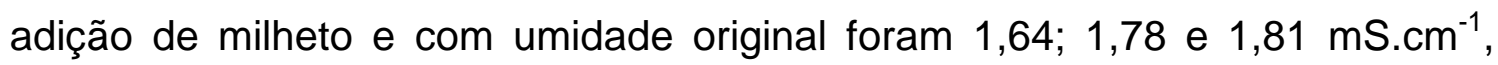


respectivamente. A menor média foi apresentada por silagens emurchecidas, diferindo das demais $(P<0,05)$, que não diferiram entre si.

Estes valores de CE estão abaixo dos obtidos por Igarasi (2002), que foram de $2,07 \mathrm{mS} . \mathrm{cm}^{-1}$ para silagens com umidade original e 2,28 $\mathrm{mS} . \mathrm{cm}^{-1}$ para silagens emurchecidas. Loures (2004) obteve para os tratamentos emurchecidos e sem emurchecimento valores de 1,73 e 1,20 mS.cm ${ }^{-1}$, respectivamente, onde o emurchecimento elevou o valor de $\mathrm{CE}$, demonstrando um comportamento oposto ao do presente estudo.

Castro et al. (2002b) observaram que com a elevação no teor de MS da silagem se elevou também a CE, concordando com a tendência observada por Loures (2004), fato esse não ocorrido neste trabalho.

Quanto ao efeito do uso de inoculante bacteriano, Castro et al. (2001b) constataram menor valor de CE $\left(0,84 \mathrm{mS} \mathrm{cm}^{-1}\right)$ com o uso de inoculante que com silagens sem inoculante $\left(0,93 \mathrm{mS} . \mathrm{cm}^{-1}\right)$. No presente estudo o inoculante bacteriano não alterou o valor de CE, apresentando-se como 1,70 e 1,80 $\mathrm{mS} . \mathrm{cm}^{-1}$ para silagens com e sem inoculante $(P=0,10)$, respectivamente.

$O$ valor de CE indica, indiretamente, o grau de ruptura celular que ocorreu durante o processamento da forragem, liberando eletrólitos do conteúdo que foram quantificados.

Assim, relaciona-se com tamanho de partícula, pois quanto menor o seu tamanho médio espera-se que maior seja o valor de CE dessa forragem. Consequentemente vai correlacionar-se com produção de afluente, pois para uma mesma forragem quanto menor seu tamanho de partícula, resultante de processamento físico intenso, maior a liberação de efluente da massa.

\subsubsection{Densidades de massa verde (DMV) das silagens}

No que se refere à DMV, a análise da Tabela 2 sugere que houve efeito de teor de matéria seca $(P<0,01)$, não havendo efeito do uso de inoculante bacteriano $(P=0,76)$. 
Os valores médios de DMV para os tratamentos emurchecidos, com adição de milheto e com umidade original foram 346, 454 e $442 \mathrm{~kg} \cdot \mathrm{m}^{-3}$, respectivamente, sendo que silagens emurchecidas apresentaram a menor DMV diferindo das demais, que não diferiram entre si.

São valores pouco inferiores aos obtidos por Igarasi (2002), 643 e 487 $\mathrm{kg} \cdot \mathrm{m}^{-3}$ para tratamentos com umidade original e emurchecidos, respectivamente. Loures (2004) obteve para os mesmos tratamentos os valores de 795 e $773 \mathrm{~kg} \cdot \mathrm{m}^{-3}$ respectivamente, também acima dos obtidos no presente experimento.

Os valores de DMV desse trabalho situam-se abaixo dos encontrados na literatura, como exemplo, a média de $576 \mathrm{~kg} \cdot \mathrm{m}^{-3}$ (Mari, 2003) com capim Marandu e $596 \mathrm{~kg} \cdot \mathrm{m}^{-3}$ obtido por Igarasi (2002) com capim Tanzânia.

Narciso Sobrinho et al. (1998a) ao emurchecer capim Elefante, indo de 19 para $24,7 \%$ de $\mathrm{MS}$, reduziram a DMV de 536 para $523 \mathrm{~kg} \cdot \mathrm{m}^{-3}$, valores superiores aos obtidos neste experimento (442 vs $346 \mathrm{~kg} \cdot \mathrm{m}^{-3}$ ).

É reconhecido que o emurchecimento, elevando o teor de MS, dificulta a compactação da massa, gerando silagens menos densas. No entanto, neste trabalho mesmo silagens com umidade original tiveram suas médias de DMV abaixo do esperado e relatado na literatura, que seria acima de $550 \mathrm{~kg} \cdot \mathrm{m}^{-3}$ (Igarasi, 2002; Mari, 2003; Loures, 2004).

Esse comportamento pode ter as seguintes explicações. Primeiro seria a dificuldade na compactação pelo tamanho médio de partícula $(4 \mathrm{~cm})$ não ter sido tão reduzido. A segunda seria quanto à pressão de compactação exercida nos silos experimentais, o que não tem como ser quantificado e comparado com outros experimentos.

Ainda, outra possibilidade é o maior teor de MS que a forragem apresentou nesse experimento, sabendo-se ser esse um fator responsável pela redução na densidade da silagem.

A forragem ensilada por Igarasi (2002) apresentou teor de MS de $16,35 \%$ sem o emurchecimento e $21,55 \%$ quando emurchecida, enquanto 
nesse experimento os teores foram, respectivamente 20,25 e $28,50 \%$. Loures (2004) ensilou forragens emurchecidas e sem emurchecimento contendo 25,73 e $16,75 \%$ de MS, respectivamente, e Mari (2003) ensilou capim Marandu contendo $19,4 \%$ de MS no verão. O fato desses autores terem utilizado forragens com menor teor de MS explica, em parte, a obtenção de maiores DMV em relação aos valores obtidos nesse experimento.

\subsubsection{Densidades de matéria seca (DMS) das silagens}

Para DMS houve efeito de teor de matéria seca $(P<0,01)$, não sendo detectado efeito do uso de inoculante bacteriano $(P=0,94)$, como apresentado na Tabela 2.

Os valores médios de DMS para os tratamentos emurchecidos, com adição de milheto e com umidade original foram 105, 144 e $97 \mathrm{~kg} \cdot \mathrm{m}^{-3}$, respectivamente, havendo diferença significativa entre essas médias.

Esses valores estão próximos aos observados por Igarasi (2002), 100; 104 e $180 \mathrm{~kg} \cdot \mathrm{m}^{-3}$, para os tratamentos com umidade original, emurchecidos e com adição de polpa cítrica, respectivamente, enquanto Mari (2003) obteve 111 kg.MS. $\mathrm{m}^{-3}$ em silagem de capim Marandu com umidade original.

Apesar da DMV estar abaixo de valores obtidos por Igarasi (2002), Loures (2004) e Mari (2003), a DMS está próxima, o que era esperado uma vez que a forragem na ensilagem do presente experimento apresentou maior teor de MS que os valores citados pelos referidos autores.

Ao elevar o teor de MS pelo emurchecimento existe a tendência de diminuir a DMV (442 vs $346 \mathrm{~kg} \cdot \mathrm{m}^{-3}$ ), elevando a DMS (Muck \& Holmes, 2000), fato esse observado no presente estudo (97 vs $105 \mathrm{~kg} \cdot \mathrm{m}^{-3}$ ) ao comparar tratamentos emurchecidos com silagens contendo teor de umidade original.

No caso de silagens adicionadas com milheto a elevação do teor de MS não contribuiu para a redução na DMV, como ocorrido com o emurchecimento, pois a participação do grão eleva ambas DMV e DMS. 
Como descrito acima os tratamentos impostos à forragem na ensilagem podem gerar valores de DMV que não seguirão a mesma tendência quanto à DMS, pois esta última variável depende do teor de MS da forragem ensilada.

\subsubsection{Perdas por gases das silagens}

Resultados referentes aos valores de perdas por gases (\% MS) são apresentados na Tabela 2, evidenciando que houve tendência de efeito de teor de matéria seca $(P=0,08)$ e do uso de inoculante bacteriano $(P=0,07)$ sobre essa variável.

Os valores médios de perdas por gases para os tratamentos emurchecidos, com adição de milheto e com umidade original foram 6,16, 4,97 e 6,40\% da MS, respectivamente. Apenas silagens adicionadas com milheto foram significativamente inferiores às demais, que não diferiram entre si. Com o uso de inoculante bacteriano as perdas na forma de gases foram de 5,34\% MS e de $6,34 \%$ MS nas silagens sem o uso de aditivo bacteriano.

Estes valores de perdas por gases encontram-se abaixo dos obtidos por Igarasi (2002) que foi de 7,25\% para silagens com umidade original, e acima dos 5,85\% obtidos pelo mesmo autor com silagens emurchecidas. Mari (2003) obteve 2,3\% de perdas na forma de gases em silagens de capim Marandu, contendo 20,7\% de MS, valor inferior ao do presente experimento.

Ao relacionar as perdas por gases com a DMV pode-se confirmar que nos tratamentos emurchecidos a perda por gases foi mais elevada $(6,16 \%$ da MS) que em silagens com adição de milheto (4,97\% da MS). Como ambas objetivaram elevar o teor de MS para 30\%, fica evidente que o que determinou a maior perda na forma de gases não foi o teor de MS mas a dificuldade em se compactar o material emurchecido, gerando portanto silagens menos densas (DMV). A menor DMV de silagens emurchecidas favorece maior retenção de 
oxigênio na massa e respiração aeróbica, podendo prejudicar a fermentação e a preservação de frações nutritivas como proteínas e carboidratos.

Também pode ser observado que a perda gasosa em silagens com umidade original foi $6,40 \%$ da MS, muito próxima ao de silagens emurchecidas. Conforme descrito por Woolford (1984), o elevado teor de umidade pode estimular a perda gasosa, pois ambiente úmido favorece o desenvolvimento de microrganismos, tanto os láticos como os clostrídios, que são responsáveis por perdas acentuadas.

A redução na produção de gases, atribuída ao uso de inoculante bacteriano, ocorre pela rápida e intensa acidificação do meio evitando o desenvolvimento de microrganismos indesejáveis, estabilizando as condições ambientais na massa ensilada quanto às fermentações. No entanto, no presente experimento, o efeito do uso do inoculante não foi tão intenso a ponto de diferir de silagens sem inoculante, sendo o resultado apresentado apenas como uma tendência.

\subsubsection{Produção de efluente das silagens}

Com o emurchecimento pretende-se elevar o teor de matéria seca da forragem, favorecendo sua fermentação e diminuindo perda por efluente (Lavezzo, 1985), assim como a adição de material com elevado teor de matéria seca e características absorventes.

Resultados referentes aos valores de perdas por efluente (kg.t MV ${ }^{-1}$ ) são apresentados na Tabela 2, onde pode ser observado que houve efeito de teor de matéria seca $(P<0,01)$ mas não houve efeito para uso de inoculante $(P=0,65)$.

Os valores médios de perdas por efluente para os tratamentos emurchecidos, com adição de milheto e com umidade original foram 3,55; 16,81 e 53,66 kg.t MV ${ }^{-1}$, respectivamente, havendo diferença significativa entre eles $(P<0,01)$. 
Os valores de perdas por efluente, observados no presente estudo, estão próximos aos obtidos por Igarasi (2002), que observou 51,8 kg.t MV ${ }^{-1}$ para silagens com umidade original. No entanto, este autor obteve perda por efluente de 32,3 kg.t $\mathrm{MV}^{-1}$ para silagens emurchecidas, acima do obtido no presente trabalho (3,55 kg.t $\mathrm{MV}^{-1}$ ), por ensilar material emurchecido com somente $22 \%$ de MS em comparação aos $27,98 \%$ de MS atingidos no presente experimento.

Mari (2003) obteve 39,6 kg.t $\mathrm{MV}^{-1}$ como perdas por efluente em silagens de capim Marandu (20,7\% MS), valor abaixo do obtido neste estudo para silagens com umidade original contendo teor semelhante de MS.

Com base nos dados deste experimento fica evidente a relação entre teor de MS e produção de efluente, como comentado por Jones \& Jones (1995). E, assim como ocorreu neste trabalho, Haigh (1999) não obteve efeito do uso de inoculante bacteriano sobre a produção de efluente.

Embora os tratamentos emurchecidos e adicionados com milheto tenham sido ensilados com 28,49 e $29,13 \%$ de MS, respectivamente, a produção de efluente foi maior para silagens adicionadas com milheto $(18,06$ kg.t MV ${ }^{-1}$ ) que nas emurchecidas $\left(3,55 \mathrm{~kg} \cdot \mathrm{t} \mathrm{MV}^{-1}\right)$.

Isto demonstra que o milheto grão moído embora tenha elevado o teor de MS da mistura (29,10\% na abertura dos silos) para próximo daquele obtido pelo emurchecimento $(27,98 \%)$ não se constituiu em substrato com boa capacidade de absorção do efluente liberado, sendo o emurchecimento mais eficiente em reduzir perdas por efluente que a adição de milheto. Isso evidencia o fato de que o aditivo com características para elevar o teor de MS pode ou não reter a umidade desprendida da massa de forragem.

\subsubsection{7 Índice de recuperação de matéria seca (RMS) das silagens}

Quanto aos valores dos índices de recuperação de matéria seca (RMS), apresentados na Tabela 2, pode ser observado que houve efeito do teor 
de matéria seca $(P<0,05)$, do uso de inoculante bacteriano $(P<0,05)$ e da interação entre teor de matéria seca e inoculante bacteriano $(P<0,05)$ sobre 0 índice de recuperação de matéria seca.

Valores médios de RMS para os tratamentos emurchecidos, com adição de milheto e com umidade original foram 92,19; 93,62 e 90,58\%, respectivamente. Tratamentos emurchecidos não diferiram dos demais, mas houve diferença significativa entre aqueles com adição de milheto e com umidade original. Com adição de inoculante a RMS foi de 91,07\% e sem inoculante de 93,19\%.

A interação entre teor de matéria seca e inoculante bacteriano foi significativa $(P<0,05)$ portanto, somente havendo diferença entre tratamentos com adição de milheto $(93,62 \%)$ e o tratamento com umidade original com inoculante $(87,6 \%)$.

Os dados de RMS dos tratamentos emurchecidos (92,2\%) estão próximos aos $94,05 \%$ obtidos por Igarasi (2002), no entanto a RMS para tratamentos com umidade original deste mesmo autor $(88,05 \%)$ está abaixo do obtido neste experimento $(90,6 \%)$.

Loures (2004) obteve para tratamentos emurchecidos e sem emurchecimento 79,5 e $72,3 \%$ de RSM, respectivamente, que também estão abaixo dos observados no presente experimento.

Kung Jr \& Ranjit (2001) aplicando inoculante bacteriano em silagem de cevada não observaram alteração na RMS, com média de 94\%. No presente experimento o uso de inoculante diminuiu a RMS, de 93,19\% para 91,07\%, contradizendo o objetivo de sua recomendação que seria favorecer a fermentação, preservando a silagem das perdas.

Ao se relacionar estes dados de RMS com as perdas na forma de gases e efluente, considerando que o uso de inoculante bacteriano diminuiu a produção de gases e efluente, esperava-se que conseqüentemente tratamentos inoculados tivessem maior RMS, mas o inverso ocorreu. 
Uma provável explicação reside no fato que o método de determinação da MS pode gerar perdas significativas da fração de ácidos graxos voláteis da silagem, durante a secagem em estufa de ventilação forçada. Ou mesmo ser atribuído a desvios na pesagem, resultando em valores de RMS que não condizem com as expectativas.

Quanto ao efeito do teor de MS na ensilagem apenas tratamentos com adição de milheto foram eficiente em reduzir perdas gasosas. Tanto o emurchecimento quanto a adição de milheto reduziram produção de efluente, embora o emurchecimento tenha sido mais eficiente. Assim o pior índice de RMS foi obtido com os tratamentos com umidade original $(90,58 \%)$, os quais apresentaram maiores perdas na forma de gás e efluente ficando o melhor índice de RMS para tratamentos com adição de milheto (93,62\%).

Os tratamentos emurchecidos tiveram taxa de RMS intermediária pois, apesar de terem perdido menos efluente do que aqueles adicionados com milheto (3,55 vs 18,06 kg. t $\mathrm{MV}^{-1}$ ), sua produção de gás foi superior, assemelhando-se às silagens com umidade original, (6,16 vs 4,97\% MS).

As considerações acima evidenciam a variação que existe entre os fatores envolvidos na RMS, ou seja, cada procedimento adotado na ensilagem interfere nas perdas individuais, refletindo na RMS.

\subsubsection{Composição químico-bromatológica das silagens}

Os resultados da composição químico-bromatológica das silagens de capim Tanzânia, confeccionadas com as forragens submetidas a diferentes tratamentos, podem ser observados na Tabela 3.

\subsubsection{Teor de matéria seca (MS) das silagens}

Os resultados referentes ao teor médio de MS das silagens de capim Tanzânia estão apresentados na Tabela 3, onde pode ser observado que houve 
efeito do teor de matéria seca da forragem na ensilagem $(P<0,01)$, apesar de não ter sido detectado efeito do uso de inoculante bacteriano $(P=0,17)$.

Os teores de MS das silagens nos tratamentos com umidade original, emurchecido e com adição de milheto diferiram entre si com médias de 20,06; 27,98 e 29,10\%, respectivamente, evidenciando a eficácia destes dois últimos procedimentos em elevar o teor de MS para teores semelhantes.

Esses valores estão acima dos obtidos por Igarasi (2002) que foram de 16 ; 27 e 21\%, respectivamente para tratamentos com umidade original, adicionado de polpa cítrica e emurchecido. É que a forragem colhida aos 45 dias por este autor apresentava em média $16 \%$ de MS e no presente experimento, em se tratando de uma forragem em estádio vegetativo um pouco mais avançado (60 dias), apresentou 20\%de MS.

Apesar da forragem ter sido deixada no campo para desidratação por tempo considerado suficiente, aproximadamente seis horas, o teor de MS da silagem final (Tabela 3 ) foi ligeiramente menor ( 28,5 vs $28,0 \%$ ) que aquele na ensilagem (Tabela 1), o que pode ter sido atribuído ao fato da forragem não ter sido revolvida durante o emurchecimento, promovendo desidratação desuniforme na camada espalhada sobre o solo.

O emurchecimento, por aproximadamente seis horas, alterou o teor de MS de 20,06 para 27,98\%, elevação de 39\%. Vilela et al. (2001) ao submeter capim Elefante, com teor de MS inicial de 17,5\%, ao mesmo tempo de emurchecimento de seis horas, obtiveram 25,6\% MS final, correspondendo a um aumento de em $46 \%$ no teor de MS, atribuído às melhores condições do tempo ou pelo fato do material ter sido desidratado em camadas mais finas espalhadas sobre o solo.

O emurchecimento, por aproximadamente seis horas, alterou o teor de MS de 20,06 para 27,98\%, elevação de $39 \%$. Vilela et al. (2001) ao submeter capim Elefante, com teor de MS inicial de 17,5\%, ao mesmo tempo de emurchecimento de seis horas, obtiveram 25,6\% MS final, correspondendo a 
Tabela 3. Composição químico-bromatológica das silagens de capim Tanzânia submetidas aos efeitos do teor de matéria seca e uso de inoculante bacteriano na ensilagem

\begin{tabular}{|c|c|c|c|c|c|c|c|c|c|c|}
\hline \multirow[b]{3}{*}{ Variáveis } & \multicolumn{6}{|c|}{ Tratamentos } & \multirow[b]{3}{*}{$\mathrm{CV}^{2}$} & \multirow{2}{*}{\multicolumn{3}{|c|}{ Efeitos $^{1}$}} \\
\hline & \multicolumn{2}{|c|}{ Original } & \multicolumn{2}{|c|}{ Emurchecido } & \multicolumn{2}{|c|}{ Milheto } & & & & \\
\hline & $\mathrm{Sem}^{3}$ & Com & Sem & Com & Sem & Com & & 1 & 2 & 3 \\
\hline Matéria Seca, \% & 20,3 & 19,8 & 28,3 & 27,6 & 29,6 & 28,6 & 7,1 & ** & 0,2 & 0,9 \\
\hline Cinzas \% MS & 11,7 & 12,0 & 12,0 & 11,8 & 8,5 & 8,4 & 5,6 & ** & 0,9 & 0,4 \\
\hline Proteína Bruta, \% MS & 7,0 & 7,6 & 7,4 & 7,5 & 11,0 & 11,4 & 11,3 & ** & 0,2 & 0,8 \\
\hline Fibra em Detergente Neutro, \% MS & 70,2 & 69,1 & 67,2 & 68,2 & 45,8 & 47,6 & 4,8 & ** & 0,5 & 0,4 \\
\hline Fibra em Detergente Ácido, \% MS & 48,7 & 49,2 & 45,8 & 45,9 & 31,3 & 31,8 & 7,3 & ** & 0,7 & 0,9 \\
\hline Lignina, \% MS & 5,8 & 5,8 & 5,7 & 5,9 & 3,7 & 4,0 & 6,8 & ** & & 0,6 \\
\hline Celulose, \% MS & 42,7 & 42,6 & 39,5 & 39,5 & 27,4 & 27,5 & 8,0 & ** & 0,9 & 0,9 \\
\hline Hemicelulose, \% MS & 21,1 & 20,5 & 21,1 & 21,6 & 13,5 & 13,9 & 5,3 & ** & 0,7 & 0,3 \\
\hline Carboidratos Solúveis, \% MS & 0,5 & 0,5 & 0,5 & 0,6 & 0,7 & 1,0 & 40,8 & $\star \star$ & 0,1 & 0,2 \\
\hline Nitrogênio amoniacal, \% N total & 10,6 & 8,5 & 2,4 & 3,7 & 2,4 & 1,9 & 62,2 & ** & 0,6 & 0,3 \\
\hline $\mathrm{pH}$ & 4,9 & 4,9 & 4,6 & 4,6 & 4,9 & 4,5 & 5,9 & * & 0,1 & 0,1 \\
\hline Nitrogênio insolúvel em FDA, \% $\mathrm{N}$ total & 15,4 & 15,0 & 14,3 & 14,5 & 8,7 & 8,1 & 14,0 & ** & 0,5 & 0,8 \\
\hline
\end{tabular}

${ }^{1}$ efeitos: 1 = matéria seca (ms); 2 = inoculante (inoc); 3 = ms $\times$ inoc.

${ }^{2} \mathrm{CV}=$ coeficiente de variação, \%.

${ }^{3}$ Sem e Com inoculante bacteriano.

** $P<0,01 ; * P<0,05 ; \quad P<0,10$. 
um aumento de em $46 \%$ no teor de MS, atribuído às melhores condições do tempo ou pelo fato do material ter sido desidratado em camadas mais finas espalhadas sobre o solo.

Narciso Sobrinho et al. (1998a) elevaram o teor de MS de 20,42 para $27,23 \%$ MS ao emurchecer capim Elefante picado durante quatro horas, sendo este aumento de $33 \%$ no teor de MS obtido com camadas finas e no mínimo dois revolvimentos da forragem durante a desidratação.

Em condições semelhantes às desse experimento, ou seja, colheita da mesma área, com mesma colhedora e procedimento, Loures (2004) conseguiu, com o emurchecimento, elevar o teor de MS de 18 para $22 \%$ em silagem de capim Tanzânia.

Nota-se que procedimentos de emurchecimento e adição de milheto grão moído foram eficientes em elevar o teor de MS da forragem na ensilagem, atingindo o objetivo proposto. A opção por um deles vai depender assim de outros fatores envolvidos e da operacionalidade.

\subsubsection{Teor de cinzas (CZ) das silagens}

Os resultados referentes ao teor médio de CZ das silagens de capim Tanzânia estão apresentados na Tabela 3, evidenciando que houve efeito do teor de MS $(P<0,01)$ mas não sendo observado efeito para o uso de inoculante bacteriano $(P=0,89)$.

$\mathrm{O}$ teor médio de $\mathrm{CZ}$ para os tratamentos com umidade original, com adição de milheto e emurchecidos foi 11,83; 8,44 e 11,89\%, respectivamente, sendo que tratamentos com umidade original e emurchecidos não diferiram entre si mas ambos foram superiores aos tratamentos com adição de milheto.

Estes dados de CZ estão próximos aos obtidos nas silagens de capim Tanzânia, aos 60 dias de idade, por Crestana et al. (2001) e Loures (2004), que foi em média de 11,1\%. 
O emurchecimento não provocou alteração no teor de $\mathrm{CZ}$ no presente experimento. Entretanto, Crestana et al. (2001) obtiveram com o emurchecimento aumento no teor de CZ das silagens (11,71 vs $12,45 \%)$ sugerindo que nas silagens emurchecidas a respiração e perda de carboidratos durante desidratação fez aumentar concentração de CZ. Também há o fato de que em silagem não emurchecida ocorre perda de $C Z$ por lixiviação, fazendo aumentar ainda mais a diferença entre valores de $C Z$ obtidos entre silagens emurchecidas e com umidade original. Também Loures (2004) observou elevação do teor de CZ com o emurchecimento (10,7 vs 13,0\% CZ).

Além das possíveis explicações citadas acima pelos referidos autores, no caso do emurchecimento há ainda o fato de que silagem emurchecida tem maior probabilidade de ser contaminada com solo durante o procedimento de recolhimento. Pois a forragem se encontra picada sobre o solo e o dispositivo de recolhimento da máquina precisa ser rebaixado aumentando as chances de se deparar com irregularidades no terreno.

\subsubsection{Teor de proteína bruta (PB) das silagens}

Resultados referentes ao teor médio de PB estão apresentados na Tabela 3. Pode ser observado que houve efeito de teor de matéria seca $(P<0,01)$, apesar de não ter sido observado efeito para o uso de inoculante bacteriano $(P=0,16)$.

Os teores médios de PB para os tratamentos emurchecidos, com adição de milheto e com umidade original foram 7,43; 11,19 e 7,28\%, respectivamente, sendo que os tratamentos com milheto diferiram dos demais, que não diferiram entre si.

Segundo Woolford (1984) após o corte da planta para ensilagem iniciase a proteólise e esta será tão mais intensa quanto maior o teor de umidade na ensilagem. No entanto, como pode ser visto nos dados da Tabela 1, a forragem ensilada com umidade original apresentou $8,35 \%$ de PB e a emurchecida 
8,26\%, demonstrando que o emurchecimento não chegou a apresentar alterações importantes, o que pode ser devido ao curto espaço de tempo sob desidratação, condições favoráveis à perda de água no campo e forragem com teor de umidade original não tão elevado.

Os valores de $\mathrm{PB}$ obtidos no presente experimento encontram-se acima daqueles obtidos por Corrêa \& Cordeiro (2000), Igarasi (2002) e Loures (2004) também com capim Tanzânia, onde foram obtidas médias 6,4; 6,24 e $4,76 \%$ PB, respectivamente. Soares Filho \& Rodrigues (2001) observaram média de 10,7\% de PB ao longo do ano para capim Tanzânia, valor superior aos aqui relatados.

A adição de milheto grão enriqueceu a silagem no seu teor protéico, o que pode ter duas explicações: a primeira é a contribuição do próprio teor mais elevado de PB do milheto (14,82\% PB) na mistura final, e a segunda seria decorrente do fato de que o maior teor de MS desse tratamento restringiria a atividade de Clostridium (McDonald, 1981; Woolford, 1984; Aguiar et al., 2001), preservando assim a fração protéica da forragem.

Ávila et al. (2003 a, b) observaram o mesmo efeito, adicionando polpa cítrica, farelo de trigo ou fubá de milho, à forragem de Tanzânia e verificaram que somente a polpa cítrica colaborou para aumentar o teor de carboidratos solúveis. Os demais aditivos, embora não tenham contribuído para isto, melhoraram as características de fermentação devido ao aumento da pressão osmótica pelo aumento no teor de matéria seca da mistura, inibindo crescimento de clostrídios, assemelhando-se às conclusões obtidas por Lavezzo (1985) e Pedreira et al. (2001).

O uso de inoculante bacteriano neste trabalho não foi efetivo em preservar a PB nas silagens e, apesar de ter havido tendência do inoculante preservar a fração protéica ( 8,83 vs $8,43 \%$ ), esta diferença de $4,5 \%$ não foi significativa $(P=0,16)$, assim como também observado por Coan et al. (2001) com silagens de capim Tanzânia e Mombaça. 
Kung \& Ranjit (2001) obtiveram maior teor de PB nas silagens na presença do inoculante, resultante da rápida queda no $\mathrm{pH}$ inibindo microrganismos que degradam proteína (Muck \& Kung Jr., 1997; Winters et al., 2001; Castro et al., 2001a, b), revelado pelo fato de menor proporção de PB ter sido degradada e perdida na forma de amônia.

Os teores de PB de 9,27\% na ensilagem e 8,65\% nas silagens demonstram que apenas $6,7 \%$ da PB foi perdida durante a ensilagem, não havendo efeito pronunciado do uso de inoculante e nem do emurchecimento.

\subsubsection{Teor de nitrogênio amoniacal $\left(\mathrm{N}-\mathrm{NH}_{3}\right)$ das silagens}

Resultados referentes ao teor de $\mathrm{N}-\mathrm{NH}_{3}$ (\% N total) podem ser vistos na Tabela 3. Houve efeito de teor de matéria seca $(P<0,01)$ não havendo efeito de inoculante bacteriano $(P=0,61)$ sobre a concentração de $\mathrm{N}-\mathrm{NH}_{3}$.

Os valores médios de $\mathrm{N}-\mathrm{NH}_{3}$ para os tratamentos emurchecidos, com adição de milheto e com umidade original foram 3,06; 2,13 e 9,52\%, respectivamente, sendo que apenas silagens com umidade original diferiram significativamente das demais que não diferiram entre si.

Contrariando o que se esperava, o uso de aditivo bacteriano não reduziu o teor de $\mathrm{N}-\mathrm{NH}_{3}$ e silagens aditivadas com inoculante apresentaram teor de $\mathrm{N}-\mathrm{NH}_{3}$ de $4,68 \%$ enquanto que em silagens sem inoculante o teor foi $5,12 \% \mathrm{~N}$ total.

Os valores de $\mathrm{N}-\mathrm{NH}_{3}$ aqui obtidos estão abaixo dos obtidos por Loures (2004), que foram de 7,8 e $17,1 \%$ do $\mathrm{N}$ total para os tratamentos emurchecidos e sem emurchecimento, respectivamente, embora os dados do presente trabalho tenham apresentado a mesma tendência para os tratamentos impostos.

Os valores aqui verificados também estão abaixo dos valores obtidos por Pedreira et al. (2001) para Tifton com umidade original e emurchecido, que foram 11,8 e 6,0\%, respectivamente. Abaixo também dos valores de Lavezzo 
(1985) que citou média de 15\% em silagens de capim Elefante e dos valores de 11,0 a 19,0\% obtidos por Corrêa \& Cordeiro (2000), com silagens de capim Tanzânia (20 a 22\% MS) sem aditivo.

Narciso Sobrinho et al. (1998a) quantificaram em silagens de capim Elefante com umidade original e emurchecida os respectivos valores de 11,16 e $5,19 \% \mathrm{~N}-\mathrm{NH}_{3}$, que são valores também acima dos obtidos no presente experimento.

No entanto o valor de $\mathrm{N}-\mathrm{NH}_{3}$ para silagens com umidade original do presente trabalho $(9,52 \%)$ está acima do obtido por Coan et al. (2001), que foi de 5,7\% com inoculante bacteriano e 5,5\% sem o inoculante bacteriano, também não havendo efeito do aditivo.

Assim como ocorreu no presente experimento, Corrêa \& Cordeiro (2000) também conseguiram reduzir em média $28 \%$ a produção de amônia com a adição polpa cítrica como material absorvente, criando no meio condições não favoráveis aos clostridios .

Segundo Marsh (1979) o emurchecimento é menos efetivo em evitar degradação protéica na silagem do que em restringir a degradação de carboidratos solúveis, pois grande parte da fração protéica é degradada pela atividade de enzimas da própria planta o que não é efetivamente controlado com o emurchecimento.

Mesmo assim, o nitrogênio volátil na forma de $\mathrm{N}_{-} \mathrm{NH}_{3}$, como percentagem do $\mathrm{N}$ total, é diminuído elevar-se o teor de MS da forragem na ensilagem, comprovado neste experimento, e já explicado, por criar no meio uma maior pressão osmótica que desencoraja a ação de clostrídios, de modo que silagens emurchecidas podem ser estáveis em $\mathrm{pH}$ de valor 5 ou até superior.

Woolford (1984) cita que o maior benefício do emurchecimento sobre a fermentação da silagem é a relativa superior tolerância das bactérias homoláticas à baixa umidade, em relação aos clostrídios que ficam mais limitados. 
Benachio (1965), citado por Sobrinho et al. (1998a), classifica silagens muito boas aquelas contendo de 0 a $10 \%$ de $\mathrm{N}-\mathrm{NH}_{3}$ (\% $\mathrm{N}$ total), boas as que contêm de 10 a 15\%, aceitáveis aquelas com 15 a 20\% e ruins aquelas que apresentam acima de $20 \%$ de N amoniacal. Silveira (1975) define uma boa silagem quando possui $\mathrm{pH}$ inferior a 4,2 e nitrogênio amoniacal até $8 \%$ do $\mathrm{N}$ total.

Considerando esses parâmetros as silagens obtidas nesse estudo seriam consideradas de boa qualidade quanto ao teor de $\mathrm{N}-\mathrm{NH}_{3}$ (média 4,9\% do $\mathrm{N}$ total) mas deixariam a desejar quanto ao valor de $\mathrm{pH}$, que foi em média de 4,7, apesar de não ser esta diferença muito grande.

\subsubsection{Teor de nitrogênio insolúvel em detergente ácido (N-FDA)}

Resultados referentes ao teor N-FDA são apresentados na Tabela 3 Pode ser notado que houve efeito somente de teor de matéria seca $(P<0,01)$ não havendo efeito de inoculante bacteriano $(P=0,55)$ sobre essa variável.

Os teores médios de N-FDA (\% N total) para os tratamentos emurchecidos foi de 14,43\%, com umidade original 15,21\% e com adição de milheto 8,39\%, sendo que somente este último diferiu dos demais. Os tratamentos emurchecidos e com umidade original não diferiram entre si, mas ambos diferiram daqueles adicionados com milheto.

Estes valores de N-FDA estão abaixo dos obtidos por Igarasi (2002), que foram em média 21,7\% para silagens emurchecidas e 20,65\% para silagens com umidade original.

O emurchecimento reduziu o teor de N-FDA em 20\% (15,46 vs 12,87\%) em experimento de Aguiar et al. (2001), embora nesse trabalho silagens emurchecidas não tenham diferido das silagens com umidade original $(14,43$ vs $15,21 \% \mathrm{~N}-\mathrm{FDA})$.

Atribui-se elevado teor de N-FDA ao efeito do aquecimento que pode ocorrer durante a ensilagem, reação denominada de Maillard, na qual açúcares 
e aminoácidos são polimerizados elevando o teor de N-FDA da silagem (Rotz \& Muck, 1994). Silagens emurchecidas geralmente têm maior propensão ao aquecimento devido difícil consolidação, que ao reter mais oxigênio na massa promovem respiração e aquecimento mais intensos. No entanto, no presente experimento, silagens emurchecidas não apresentaram valores superiores às não emurchecidas.

\subsubsection{Teor de fibra insolúvel em detergente neutro (FDN) das silagens}

Resultados referentes ao teor médio de FDN estão apresentados na Tabela 3. Houve efeito de teor de matéria seca $(P<0,01)$ apesar de não ter sido observado efeito do uso de inoculante bacteriano $(P=0,51)$ sobre o teor de FDN nas silagens.

Os valores médios de FDN para os tratamentos emurchecidos, com adição de milheto e com umidade original foram 67,69; 46,68 e 69,64\%, respectivamente, sendo que houve diferença significativa entre as três médias. O menor teor de FDN observado em silagens com milheto é atribuído ao efeito de diluição.

Valores de FDN de 68 a 70,5\% observados por Crestana et al. (2001) e Soares Filho \& Rodrigues (2001) encontram-se muito próximos os $69,64 \%$ aqui observados, para silagens de capim Tanzânia.

Crestana et al. (2001) e Pedreira et al. (2001) observaram o mesmo comportamento com capins Tifton 85 e Tanzânia, havendo manutenção do teor de FDN da silagem pelo emurchecimento, e redução em seu teor ao adicionar polpa cítrica.

Loures (2004) observou maior teor de FDN em silagens de capim Tanzânia sem emurchecimento (72,4 vs 67,9\%). e Vilela et al. (2001) observaram que ao emurchecer capim Elefante por seis horas não houve efeito no teor de FDN, mas ao emurchecer por 12 horas houve redução do seu teor. 
Em contrapartida, Igarasi (2002) obteve maior teor de FDN nos tratamentos emurchecidos.

Os valores de FDN apresentados neste experimento, superiores aos obtidos por Igarasi (2002), explicam-se pelo fato de que em seu trabalho a gramínea foi colhida com 64,3\% FDN e, no presente trabalho, a planta em estádio mais avançado, apresentou 69,88\% FDN. Contudo são valores inferiores aos 77,8\% FDN obtidos por Coan et al. (2001) também avaliando capim Tanzânia com 60 dias de crescimento.

A idade da planta pode ser um referencial ao avaliar sua composição bromatológica, no entanto diferentes condições ambientais e climáticas podem ser responsáveis por variações nas concentrações das diferentes frações.

\subsubsection{Teor de fibra insolúvel em detergente ácido (FDA) das silagens}

Resultados referentes ao teor de FDA estão apresentados na Tabela 3. Houve efeito de teor de matéria seca $(P<0,01)$ não havendo efeito de inoculante bacteriano $(P=0,71)$ sobre o teor de FDA das silagens.

Os valores médios de FDA para os tratamentos emurchecidos, com adição de milheto e com umidade original foram de 45,81; 31,50 e 48,94\%, respectivamente, havendo diferença significativa entre essas três médias.

Loures (2004) emurchecendo Tanzânia também observou redução no teor de FDA de 44,4 para 42,1\% na MS, embora Pedreira et al. (2001) não tenham observado alteração no teor de FDA ao emurchecer Tifton 85 por seis horas (43,3 vs 43,7\%). Crestana et al. (2001) ao emurchecerem capim Tanzânia reduziram o teor de FDA das silagens de 42,46 para 40,39\%.

Estes valores de FDA estão de acordo com os obtidos por Igarasi (2002) que, mesmo colhendo forragem mais nova do que no presente trabalho, obteve em média 45,83\% de FDA para tratamentos com umidade original, $33,22 \%$ para tratamentos adicionados com milheto e $45,13 \%$ para tratamentos 
emurchecidos, enquanto Soares Filho \& Rodrigues (2001) obtiveram valor inferior de FDA (44\%).

Todos estes valores são ligeiramente inferiores aos 49\% obtidos em silagens com umidade original por Coan et al. (2001) em silagens de Tanzânia com 60 dias de crescimento, e superiores aos verificados por Crestana et al. (2001), que obtiveram média de FDA de 41\% para silagem de Tanzânia com umidade original e 38,62\% para silagem de Tanzânia emurchecida.

Assim como ocorreu para FDN a adição de milheto reduziu o teor de FDA da mistura pelo efeito de diluição.

\subsubsection{Teor de lignina das silagens}

Na Tabela 3 estão apresentados os valores verificados para lignina, podendo ser observado efeito de teor de matéria seca $(P<0,01)$ sobre essa variável e tendência de efeito para o uso de inoculante bacteriano $(P=0,06)$.

Os teores médios de lignina para os tratamentos emurchecidos, com adição de milheto e com umidade original foram 5,80; 3,86 e 5,80\%, respectivamente, havendo diferença apenas entre o milheto e os demais, que não diferiram entre si. O teor médio de lignina para silagens com inoculante foi de 5,25\% e sem inoculante foi de 5,05\%, discordando de Coan et al. (2001) que observaram tendência oposta (7,8 vs 8,2\%) ao inocular silagem de capim Tanzânia.

Tais valores de lignina obtidos neste trabalho estão acima da média de $4,27 \%$ constatada por Loures (2004), mas de acordo com os obtidos por Igarasi (2002), com média de 5,6\% para tratamentos com umidade original e emurchecidos. Entretanto, são inferiores aos obtidos $(7,95 \%)$ por Coan et al. (2001) também usando capim Tanzânia com 60 dias de crescimento e superiores aos obtidos por Crestana et al. (2001) para silagem de capim Tanzânia com umidade original (3,69\%) e emurchecida (3,20 \%). 


\subsubsection{Teor de hemicelulose das silagens}

Resultados referentes ao teor de hemicelulose são apresentados na Tabela 3. Houve efeito de teor de matéria seca $(P<0,01)$, apesar de não ter sido observado efeito do uso de inoculante bacteriano $(P=0,73)$ sobre o teor de hemicelulose das silagens de capim Tanzânia.

Os valores médios de hemicelulose para os tratamentos emurchecidos foi de 21,34\%, com adição de milheto 13,68\% e com umidade original de $20,82 \%$, respectivamente, sendo que somente a segunda média diferiu das demais que foram estatisticamente semelhantes.

Estes valores de hemicelulose estão próximos aos relatados por Igarasi (2002), que foram de 24,45 e 21,75\% para tratamentos emurchecidos e com umidade original, respectivamente. Entretanto são valores inferiores aos 28,6\% obtidos por Coan et al. (2001) e aos 26,9\% verificados por Loures (2004). Coan et al. (2001) também não observaram alteração no teor de hemicelulose com adição do inoculante bacteriano em silagens de capim Tanzânia, assemelhando-se ao presente.

\subsubsection{Teor de celulose das silagens}

Resultados referentes ao teor de celulose são apresentados na Tabela 3. Houve efeito de teor de matéria seca $(P<0,01)$, porém não havendo efeito de inoculante bacteriano $(P=0,96)$.

Os valores médios de celulose para os tratamentos emurchecidos, com adição de milheto e com umidade original foram 39,51; 27,42 e 42,63\%, respectivamente, havendo diferença significativa entre elas.

Os valores de celulose encontrados no presente experimento estão acima dos obtidos por Coan et al. (2001) e por Loures (2004), 36,9 e 37,3\%, respectivamente. 
Assim como ocorreu para as demais frações fibrosas o teor de celulose apresentou-se inferior nas silagens adicionadas com milheto pelo efeito da diluição.

\subsubsection{Teor de carboidratos solúveis (CS) das silagens}

Resultados referentes ao teor de carboidratos solúveis são apresentados na Tabela 3. Houve efeito de teor de matéria seca $(P<0,01)$, porém não houve efeito para o uso de inoculante bacteriano $(P=0,14)$ sobre 0 teor de CS observado nas silagens.

Os valores médios de carboidratos solúveis (\% MS) para os tratamentos emurchecidos, com adição de milheto e com umidade original foram 0,54; 0,84 e 0,47\%, respectivamente, havendo diferença significativa apenas para tratamentos com milheto que diferiram dos demais. Silagens inoculadas tiveram tendência $(P=0,14)$ de apresentar maior teor de CS $(0,67 \%)$ do que silagens sem inoculante $(0,56 \%)$.

Os valores de carboidratos encontrados no presente experimento são inferiores aos apresentados por Loures (2004), que foram em silagens emurchecidas e sem emurchecimento de 1,12 e 0,88\%, respectivamente.

Zierenberg et al. (2001) avaliando a possibilidade de ensilagem de 6 gramíneas tropicais, dentre elas o capim Tanzânia, constataram que este capim foi o segundo mais pobre em carboidratos solúveis (2,7\% na MS), apresentando teores muito abaixo dos $4,73 \%$ detectados na forragem utilizada neste experimento (Tabela 1).

Os teores de CS observados na forragem do presente experimento estão abaixo dos obtidos por Coan et al. (2001) que foram de 8,9\% da MS para Tanzânia, confirmando que gramíneas tropicais apresentam baixos teores de CS, abaixo dos 15\% indicados por Kearney \& Kennedy (1962) para obtenção de silagens de boa qualidade, ou seja, aquelas que teriam seus valores de $\mathrm{pH}$ 
entre 3,8 e 4,2, resultante da fermentação de CS, gerando principalmente ácido lático.

Segundo Marsh (1979), o maior efeito do emurchecimento é a elevação no teor de matéria seca com ocorrência da diminuição no teor de carboidratos solúveis devido à hidrólise e respiração pela longa exposição da planta ceifada ao oxigênio. No entanto se o teor de MS do emurchecido for superior a 33\% pode atrasar ou evitar uma fermentação desejável, pela falta de liberação de líquido intracelular como substrato, preservando os carboidratos presentes na forragem emurchecida.

Assim, apesar de ocorrer perda de carboidrato no campo, da porção remanescente na forragem emurchecida, pouco será utilizado dentro do silo, resultando em menor concentração de ácidos e maior $\mathrm{pH}$ nesta silagem, fato também evidenciado por Vilela (1998).

No presente experimento, forragem com umidade original apresentou média de $4,7 \%$ de carboidratos solúveis na MS e em forragens emurchecidas a média foi de 2,9\% (Tabela 1), representando uma significativa queda de $38 \%$ no teor de CS no momento da ensilagem com a adoção do emurchecimento. No entanto o teor de CS residual nas silagens emurchecidas (0,54\% da MS) foi maior do que naquelas com umidade original $(0,47 \%$ da MS), apesar desta diferença não ter sido significativa, concordando com o que foi exposto acima, por Marsh (1979).

Após fechamento do silo, o pouco oxigênio retido na massa é rapidamente exaurido não permitindo que as células da forragem e organismos aeróbios respirem por muito tempo preservando o carboidrato presente. Loures (2004) não obteve diferença no teor de carboidratos ao diminuir tamanho de partícula (1,01 vs $0,99 \%)$, mas obteve maior teor de carboidrato residual na silagem com o emurchecimento ( 0,88 vs $1,12 \%)$.

O maior teor de carboidrato residual na silagem pode ser um fator positivo ao se avaliar qualidade de silagens, pois indica que este não foi um substrato limitante para as bactérias produzirem ácido lático, elemento com 
grande poder de preservação da massa ensilada (Vilela, 1998), até chegar um valor de pH estável.

Ávila et al. (2003a, b) adicionando polpa cítrica, farelo de trigo ou fubá de milho ao capim Tanzânia observaram que somente a polpa cítrica elevou o teor de carboidratos solúveis e que os demais aditivos, embora não tenham contribuído para isto, melhoraram as características de fermentação devido ao aumento da pressão osmótica pelo aumento no teor de matéria seca da mistura, inibindo crescimento de clostrídios, a mesma conclusão obtida por Lavezzo (1985) e Pedreira et al. (2001).

Aditivos como farelo de trigo e o fubá de milho fornecem basicamente amido o qual não é usado eficientemente pelas bactérias homoláticas como substrato (Lavezzo, 1985). O mesmo pode ter ocorrido no presente trabalho, com adição de milheto grão moído, que assim como o fubá e o trigo, fornece basicamente amido, tanto que o teor de carboidrato residual na silagem adicionada com milheto, apesar de ser maior do que para demais tratamentos, não foi tão elevado.

Sugere-se que a hemicelulose, apesar de fração fibrosa, sirva de substrato às bactérias para fermentação em ocasiões onde não existe carboidrato solúvel disponível ou suficiente (Woolford, 1984; Crestana et al., 2001). Woolford (1984) chegou a essa conclusão após observar que o ácido lático e ácidos graxos voláteis formados durante o processo de fermentação são invariavelmente superiores aos permitidos pelo teor de açúcares solúveis presentes na forragem, sugerindo então que outros substratos participem da fermentação além dos carboidratos.

Mas como não existem evidências de bactérias homoláticas atuarem na hidrólise da hemicelulose em condições laboratoriais, conclui-se que sua lise seja inicialmente feita por ação enzimática da planta e gradualmente substituída pela hidrólise ácida, o que não exclui a possibilidade de ação de bactérias homoláticas sobre a hemicelulose na ausência total de carboidratos. No entanto, no presente trabalho, não há como distinguir se o teor de carboidratos 
solúveis inicial, tido como abaixo do mínimo necessário para boa fermentação, exerceu efeito limitante a ponto de haver fermentação a partir de hemicelulose (Woolford, 1984).

\subsubsection{2 $\mathrm{pH}$ das silagens}

Resultados referentes ao $\mathrm{pH}$ das silagens são apresentados na Tabela 3. Houve efeito de teor de matéria seca $(P<0,01)$ e tendência de efeito do uso de inoculante bacteriano $(\mathrm{P}=0,10)$ sobre os valores de $\mathrm{pH}$.

Os valores médios de $\mathrm{pH}$ para os tratamentos emurchecidos foram 4,57, com adição de milheto 4,66 e com umidade original 4,86, sendo que não houve diferença entre silagens emurchecidas e com milheto mas estes diferiram daquelas com umidade original. Com a presença de inoculante o $\mathrm{pH}$ médio foi de 4,63 e sem o inoculante foi de 4,76.

Os valores de $\mathrm{pH}$ encontrados no presente experimento encontram-se um pouco abaixo dos valores obtidos por Igarasi (2002), que foram de 5,4 para silagens com umidade original e 5,20 para silagens emurchecidas, e Loures (2004), que obteve para os mesmos tratamentos com silagens de capim Tanzânia, 5,19 e 4,91, respectivamente.

Corrêa \& Cordeiro (2000) obtiveram pH de 4,4 a 4,7 para silagens de capim Tanzânia, com 21\% de MS sem aditivos, valores bem próximos aos 4,76 observado no presente estudo.

Vilela et al. (2001) observaram redução no $\mathrm{pH}$ de 3,8 para 3,0 em silagens de capim Elefante com o emurchecimento. No entanto, no presente trabalho, esta redução não foi tão intensa. Ao contrário, Crestana et al. (2001) obtiveram valores médios de $\mathrm{pH}$ para silagens de Tanzânia sem emurchecimento e com o emurchecimento de 5,37 e 5,83, respectivamente, valores esses bem superiores aos aqui encontrados.

Marsh (1979), Castro et al. (2001a, b) e Vilela et al. (2001) afirmaram que há tendência em se elevar o pH quando se aumenta o teor de MS da 
silagem pelo emurchecimento a valores acima de 4,5, efeito este não observado por Narciso Sobrinho et al. (1998a) que ao emurchecer capim Elefante reduziu o $\mathrm{pH}$ de 3,44 para 3,39. Também no presente experimento o emurchecimento não proporcionou elevação no valor de $\mathrm{pH}$.

Woolford (1984) descreveu que quanto maior o teor de MS da silagem emurchecida, maior será o pH no qual a estabilidade anaeróbia ocorre, pois estas silagens suportam menor população de lactobacilos e bactérias proteolíticas, contendo assim menos ácidos que forragens equivalentes sem o emurchecimento. Por isso silagens emurchecidas apresentam maior teor de carboidrato solúvel residual com elevação do teor de matéria seca, pois microrganismos necessitam de ambiente úmido para crescerem, além da presença de açúcares.

Os valores do presente experimento estão próximos ao obtido por Coan et al. (2001), que foi de 4,8, tanto na presença como na ausência de inoculante bacteriano.

O poder tampão medido nas forragens antes da ensilagem (Tabela 1) foram de 21,85; 19,03 e 25,57 meq.100g $\mathrm{MS}^{-1}$ para os tratamentos com umidade original, emurchecidos e com adição de milheto, respectivamente, valores estes superiores aos 15,4 observados por Coan et al. (2001).

No entanto os dados do presente trabalho concordam com Lavezzo (1985) e Vilela (1998) que mencionaram que há diminuição no poder tampão com o emurchecimento, efeito não alcançado por Vilela et al. (2001) ao emurchecer capim Elefante.

Os maiores valores de poder tampão não chegaram a constituir um obstáculo à queda no pH. Como apresentado acima, silagens emurchecidas apresentaram valor de $\mathrm{pH}$ de 4,57 e com umidade original, de 4,86.

Embora o teor de carboidratos tenha estado abaixo do recomendado como ideal para ensilagem (Kearney \& Kennedy, 1962) parece não ter sido limitante à queda no pH, pois tratamentos emurchecidos e com umidade original apresentaram valores de $\mathrm{pH}$ satisfatórios, o que está de acordo com valores 
encontrados para silagens de capim Tanzânia em outros trabalhos (Corrêa \& Cordeiro, 2000; Igarasi, 2002; Loures, 2004).

Zierenberg et al. (2001) avaliando a possibilidade de ensilagem de seis gramíneas tropicais puderam verificar que o capim Tanzânia apresentou elevados valores de poder tampão e de $\mathrm{pH}$, de 4,2 a 5,4, mesmo considerados aceitáveis.

Apesar do teor de carboidrato recomendado por Kearney \& Kennedy (1962) estar em torno de $15 \%$ na MS o fato do teor obtido neste experimento ter estado abaixo não interferiu na queda de $\mathrm{pH}$ que atingiu valores aceitáveis para silagem de capim.

Estes resultados estão de acordo com McCulloug (1977) que ressaltou que a fermentação ideal no silo é esperada quando a forragem a ser ensilada possui de 28 a 34\% de MS, sendo que nestas condições, mesmo teores de CS em torno de $6 \%$ na MS seriam suficientes para desencadear fermentações láticas, desde que o poder tampão não seja elevado.

Silveira (1975) define uma boa silagem quando possui $\mathrm{pH}$ inferior a 4,2. Sob esse ponto de vista a silagem obtida nesse experimento não atingiu o nível desejado, embora tenha chegado bem próximo.

\subsection{Conclusões}

A alteração no teor de matéria seca ou a adição de inoculante bacteriano na ensilagem de capins tropicais promoveram alterações químicofísicas nas silagens. A elevação do teor de MS foi o fator que promoveu os benefícios mais significativos na ensilagem de capim Tanzânia. Em geral, a adição de milheto moído destacou-se pela maior eficiência em relação ao emurchecimento, assim, a recomendação desses procedimentos deverá considerar a operacionalidade e custos inerentes aos processos. 


\section{EFEITO DO TAMANHO DE PARTÍCULA, TEOR DE MATÉRIA SECA E INOCULANTE BACTERIANO EM SILAGEM DE CAPIM TANZÂNIA SOBRE O COMPORTAMENTO INGESTIVO E DIGESTÃO DE NUTRIENTES EM BOVINOS DE CORTE}

\section{Resumo}

O presente estudo teve por objetivo avaliar o efeito do teor de matéria seca da forragem, o uso de inoculante bacteriano (homoláticas) e a redução do tamanho de partículas, impostos na ensilagem de capim Tanzânia (Panicum maximum, Jacq cv. Tanzânia), sobre os parâmetros de comportamento ingestivo, consumo voluntário, degradação ruminal, parâmetros de fermentação e cinética ruminal e digestibilidade dos nutrientes (intestinal e total). Utilizou-se sete novilhos da raça Nelore, portadores de cânulas ruminal e duodenal, em delineamento do tipo Quadrado Latino 7 x 7, recebendo rações contendo 87\% de concentrado (\% MS). Os tratamentos foram confeccionados da seguinte forma: T1 - Umidade original, partícula menor, sem inoculante bacteriano; T2 Umidade original, partícula menor, com inoculante bacteriano; T3 Emurchecido, partícula maior, com inoculante bacteriano; T4 - Emurchecido, partícula maior, sem inoculante bacteriano; T5 - Umidade original, partícula maior, com inoculante bacteriano; T6 - Umidade original, partícula maior, sem inoculante bacteriano; T7 - Umidade original, partícula maior, sem inoculante bacteriano, com milheto. Os parâmetros de cinética de passagem de sólidos $\left(2,4 \%\right.$ hora $\left.^{-1}\right)$ e de líquidos $\left(3,2 \%\right.$ hora $\left.^{-1}\right)$ foram similares para os tratamentos avaliados. O comportamento ingestivo dos animais não foi alterado pelos tratamentos, sendo observados os seguintes tempos (minutos dia ${ }^{-1}$ ) e taxas 
(min $\mathrm{kg} \mathrm{MS}^{-1}$ ) de ingestão de MS, de 293 e 68; de ruminação de 432 e 102 e de mastigação de 725 e 170, respectivamente. Os valores médios de digestibilidade da MS (61,4\%), FDA (59,7\%), PB (43,9\%) e FDN $(60,3 \%)$ não diferiram entre tratamentos. O consumo médio foi de 1,1\% do PV, não diferindo entre tratamentos e ficando abaixo do previsto. As médias das concentrações molares totais dos ácidos graxos voláteis e de nitrogênio amoniacal do fluido ruminal foram maiores no T7 em comparação aos demais tratamentos. Também não houve efeito de tratamento sobre o desaparecimento intestinal das silagens para MS (5,9\%), FDN (3,0\%) e FDA (4,4\%) e nem sobre os parâmetros de degradabilidade ruminal (MS, FDN, FDA e HEMI). Diante dessas observações, pode-se concluir que os procedimentos adotados na ensilagem não resultaram em alterações significativas no comportamento ingestivo, cinética ruminal, os parâmetros ruminais e a digestibilidade de nutrientes em animais.

\section{EFFECTS OF PARTICLE SIZE, DRY MATTER CONTENT AND BACTERIAL INOCULANT IN TANZANIA GRASS SILAGE ON THE INGESTIVE BEHAVIOR AND NUTRIENT DIGESTION OF BEEF CATTLE}

\section{Summary}

The trial main objective was to study the effect of dry matter content, the addition of bacterial (homolactic) inoculant and particle size reduction in the ensiling of Tanzania grass (Panicum maximum, Jacq. cv. Tanzânia) on the ingestive behavior, intake and nutrient digestion (total and intestine), ruminal fermentation and kinetics. Seven ruminally and duodenally cannulated Nellore beef steers were randomly assigned to a $7 \times 7$ Latin Square design and fed $87 \%$ silage TMR diets. Treatments were described as follows: T1: wet forage + small particle; T2: T1 + inoculant; T4: wilting + large particle; T3: T4 + inoculant; T6: wet forage + large particle; T5: T6 + inoculant; T7: T6 + ground pearl millet 
grain. The ruminal passage rate of solid $\left(2.35 \% \cdot \mathrm{h}^{-1}\right)$ and liquid $\left(3.17 \% \cdot \mathrm{h}^{-1}\right)$ phases were similar across treatments. The animal ingestive behavior was not significantly changed by treatments, averaging 293 (minutes. $\mathrm{d}^{-1}$ ) and 68 (minutes. $\mathrm{DM} \mathrm{kg}^{-1}$ ) for time and rate of eating, respectively. For rumination and chewing, the mean values observed were 432 (minutes. $^{-1}$ ), 102 (minutes. DM $\mathrm{kg}^{-1}$ ) and 725 (minutes. $^{-1}$ ), 170 (minutes. DM kg ${ }^{-1}$ ), respectively. No significant differences were observed for the DM (61.40\%), ADF (59.69\%), CP (43.93\%) and NDF (60.34\%) digestibilities. The mean DM intake (1.1\%BW) was lower than expected and not different among treatments. The molar concentration of total volatile fatty acids and ammonia- $\mathrm{N}$ were higher for $\mathrm{T} 7$ than for the other treatments. Intestinal disappearance of DM (5.90\%), NDF(3.04\%), ADF(4.36\%) and parameters of ruminal degradabilities (DM, NDF, ADF and HEMI) did not changed across treatments. According to the observed trend it might be concluded that the strategies adopted during the ensiling of Tanzania grass did not result in significant changes on the ingestive behavior, ruminal parameters and kinetics and nutrient digestibilties in beef cattle.

\subsection{Introdução}

A ingestão de matéria seca é afetada por vários fatores como enchimento físico do retículo e rúmen, feed-back metabólico, aceitabilidade, composição do alimento, entre outros. Conseqüentemente, a digestibilidade dos alimentos ingeridos definirá as taxas de passagem do alimento pelo trato digestivo, taxas de ingestão e de ruminação por $\mathrm{kg}$ de matéria seca ou $\mathrm{kg}$ de FDN, etc.

Assumindo que a ingestão voluntária de matéria seca seja limitada pelo enchimento ruminal, silagens mais digestíveis logicamente seriam ingeridas em maiores quantidades, existindo uma relação positiva entre estes dois fatores (Rinne et al., 2002). 
No entanto, isto não foi o observado por Teller et al. (1993) que utilizando silagem emurchecida constatou que apesar de apresentar menor digestibilidade aparente da matéria orgânica, foi ingerida em maiores quantidades que aquela ensilada diretamente após o corte, não comprovando a teoria acima.

Ao contrário, Loures et al. (2003a) verificaram maior degradabilidade da matéria seca com o emurchecimento do capim Tanzânia, em comparação ao não emurchecido, fato que colaborou para maior ingestão deste tipo de silagem.

Tanto o processo de mastigação quanto a degradação microbiana ruminal são essenciais na redução do tamanho de partículas em gramíneas (Wilson et al., 1989), permitindo que partículas menores saiam do rúmen, sendo esses dois processos complementares.

Tratamentos químicos e físicos, como o emurchecimento e o processamento físico da forragem na ensilagem, não alteram muito o requerimento de ruminação, nem sua composição química e digestão ruminal, embora sejam responsáveis por variações no comportamento ingestivo.

Como observado por Teller et al. (1993) o emurchecimento da gramínea na ensilagem não aumentou de modo significativo o tempo dedicado à ruminação de cada quilo de matéria seca ingerida. Há procedimentos que podem ser adotados visando melhorar a qualidade da fermentação e diminuir as perdas mas não interferem na ingestão.

Existe uma relação negativa entre ingestão de matéria seca e rações com alto teor de umidade, com diminuição da ingestão de matéria seca total à medida que se eleva a umidade da mesma. Como a maioria dos alimentos úmidos é fermentada, há decréscimo da ingestão quando estes são adicionados na ração, de modo que o efeito depressivo deve-se mais aos produtos da fermentação do que à umidade propriamente dita (NRC, 2001).

Segundo Lavezzo (1985) o uso de materiais com elevado teor de matéria seca evita não só fermentações indesejáveis e perdas da silagem, na 
forma de efluente ou por deterioração, como também proporciona maior consumo pelos animais.

O emurchecimento, embora possa melhorar as características de fermentação da silagem, produz efeitos variados quanto à ingestão e desempenho animal, devido às condições de tempo em que é realizado (Dawson et al., 1999). A taxa de perda de água no campo durante o emurchecimento é tida como a variável que explica a maior proporção de variação na ingestão de matéria seca em forragem emurchecida (Wright et al., 2000). Ou seja, o emurchecimento sob condições de tempo não favoráveis à desidratação, que prolongam o tempo de exposição da forragem, geram silagens de qualidade inferior.

Como alternativa ao emurchecimento pode-se elevar o teor de matéria seca da massa na ensilagem, através da adição de material absorvente, como polpa cítrica e grãos cereais moídos. Este procedimento oferece certas vantagens em relação ao emurchecimento, como: evita operação extra com máquinas no recolhimento; não expõe o material a risco de perda por precipitação; proporciona boa fermentação em relação à forragem sem emurchecimento; evita contaminação com solo no recolhimento (Aguiar et al., 2001; Igarasi, 2002; Ávila et al., 2003a, b; Pedreira et al., 2001) e eleva o valor nutritivo do produto final.

Outro procedimento que vem sendo amplamente adotado na ensilagem é o uso de inoculantes bacterianos. No entanto os resultados são inconsistentes, tanto na ingestão quanto no desempenho animal (Haigh, 1998; Vilela, 1998; Dawson et al., 1999).

Winters et al. (2001), comparando silagens de azevém tratadas com inoculante bacteriano elevaram o consumo em relação ao controle, assim como o ganho de peso foi 35\% superior e conversão alimentar também foi melhorada.

Muck \& Kung Jr. (1997) chegaram a concluir que embora o inoculante não tenha nenhum efeito em melhorar a estabilidade aeróbia e vida útil no cocho, melhorou em um terço dos estudos a digestibilidade da matéria seca. 
O processo de ensilagem parece ser fácil de ser conduzido quando superadas as limitações apresentadas na ensilagem, como excesso de umidade e teor reduzido de carboidrato na massa. No entanto, após obter silagem considerada de boa qualidade, é o animal que vai traduzir essa qualidade, quantificando-a através da aceitação e desempenho.

O objetivo deste experimento foi avaliar o efeito do teor de matéria seca, tamanho de partícula e uso de inoculante bacteriano sobre o comportamento ingestivo, cinética ruminal, consumo, degradação e parâmetros de fermentação ruminais e digestão (intestinal e total) de nutrientes em bovinos de corte, maximizando a participação de silagens na ração.

\subsection{Material e Métodos}

\subsubsection{Local do experimento}

O trabalho foi realizado no Departamento de Zootecnia, Setor Ruminantes, USP/ESALQ, em Piracicaba/SP. As análises bromatológicas foram conduzidas no Laboratório de Bromatologia, pertencente ao mesmo Departamento.

\subsubsection{Tratamentos adotados}

Os tratamentos adotados para a avaliação com animais foram os seguintes:

T1 - Umidade original, partícula menor, sem inoculante bacteriano;

T2 - Umidade original, partícula menor, com inoculante bacteriano;

T3 - Emurchecido, partícula maior, com inoculante bacteriano;

T4 - Emurchecido, partícula maior, sem inoculante bacteriano;

T5 - Umidade original, partícula maior, com inoculante bacteriano; 
T6 - Umidade original, partícula maior, sem inoculante bacteriano;

T7 - Umidade original, partícula maior, sem inoculante bacteriano, com milheto grão finamente moído.

\subsubsection{Aplicação dos tratamentos}

\section{a) Forragem com umidade original}

Tratamentos com umidade original compreenderam a forragem oriunda do corte direto do capim e ensilagem subseqüente.

b) Forragem emurchecida

O procedimento foi ceifar a forragem por volta das 9 horas da manhã, quando o excesso de orvalho já havia se dissipado. A janela traseira da colhedora, que fica sobre as facas coletoras móveis, foi aberta, de modo que a forragem ceifada não fosse enviada às facas do rotor e posteriormente à bica mas jogada para trás, sobre as touceiras dos resíduos. A forragem permaneceu exposta ao sol por aproximadamente 6 horas para a desidratação.

Ao final deste período foram feitos ajustes nas distâncias das contrafacas do rotor de modo que a forragem emurchecida coletada fosse picada respeitando os tratamentos de partículas impostos. Este período de 6 horas de emurchecimento foi tido como um período suficiente para elevar o teor de matéria seca a um nível desejável de 30\% (Igarasi, 2002).

c) Adição de milheto grão moído (MI)

Nos tratamentos com milheto grão moído este foi adicionado à forragem com umidade original imediatamente antes da ensilagem, de modo que a mistura homogênea atingisse teor de matéria seca próximo aos tratamentos emurchecidos, em torno de $30 \%$. Como o teor de matéria seca da forragem pelo corte direto encontrava-se em torno de $20 \%$ no momento da ensilagem, para atingir 30\% de MS foram adicionados aproximadamente $16 \mathrm{~kg}$ de milheto moído para cada $100 \mathrm{~kg}$ de forragem fresca. O milheto finamente 
moído foi adicionado simultaneamente à forragem no momento do enchimento do silo.

d) Aplicação de inoculante bacteriano

O inoculante bacteriano utilizado foi o ECOSYL ${ }^{\circledR}$ Silage Inoculant, da empresa Ecosyl ${ }^{\circledR}$ Products Ltda. (Registered in England No. 3155665), caracterizado como uma cepa de Lactobacillus plantarum, na forma de pó desidratado, com nível de garantia de 20 bilhões de UFC. $g^{-1}$ de produto. O inoculante foi diluído em água destilada, seguindo-se recomendação do fabricante visando o fornecimento 100 bilhões de UFC. $\mathrm{t}^{-1}$ de forragem, aplicando-o imediatamente antes da ensilagem, através de uma bomba costal.

e) Tamanhos de partículas: como já mencionado, foi imposto explorando-se as amplitudes máxima e mínima de distância entre as contrafacas do rotor picador. Apesar disso, o método utilizado para estratificação da forragem (Lammers et al., 1996) não foi sensível a ponto de detectar diferença entre os tamanhos médios de partículas (Tabela 4), embora visualmente essa diferença pudesse ser observada.

\subsubsection{Confecção da silagem}

A forragem Panicum maximum Jacq. cv Tanzânia, foi colhida em 07 de março de 2001, apresentando-se aproximadamente com 65 dias de rebrota, proveniente de uma área destinada à produção de forragem para ensilagem, estabelecida em solo tipo Latosolo Roxo Eutrófico.

A colheita foi realizada com a colhedora de forragem marca Siltomac ${ }^{\circledR}$ modelo 775, tracionada por trator. Antes de cada período de colheita a colhedora teve seu conjunto de facas afiado e o conjunto de contra-facas aproximado ou afastado a fim de obter os tamanhos de partículas estabelecidos para os tratamentos.

Após a forragem ser submetida aos diferentes tratamentos, esta foi acondicionada em silos tipo poço, com aproximadamente seis metros de 
profundidade e 2,46 m de diâmetro, revestidos em alvenaria, divididos ao meio por uma parede. Somente metade de cada silo poço foi preenchida para cada tratamento, quantidade suficiente para a condução do experimento.

Camadas de aproximadamente $50 \mathrm{~cm}$ foram acomodadas dentro do silo entre os ciclos de compactação com os pés, até ultrapassar a borda superior do silo em aproximadamente $50 \mathrm{~cm}$, prevendo a acomodação da massa. Finalizado o enchimento, os silos tiveram suas superfícies cobertas por lonas plásticas, as quais foram amarradas ao redor com cordas, para garantir a vedação ao ambiente externo.

A forragem ensilada foi amostrada e sua composição encontra-se apresentada na Tabela 4. Partindo destes três grupos iniciais de forragens colhidas adicionou-se inoculante bacteriano ou milheto originando os demais tratamentos.

\subsubsection{Período experimental, animais utilizados e rações}

O período experimental foi iniciado em setembro de 2001 com duração de 98 dias, dividido em 7 períodos de 14 dias, sendo 7 dias para adaptação dos animais às rações e 7 dias para coleta de amostras.

Foram utilizados sete bovinos machos castrados da raça Nelore, com peso médio inicial de $415 \mathrm{~kg}$, portadores de cânulas ruminal e duodenal, após apresentarem-se recuperados da cirurgia e adaptados às instalações.

Os animais foram alojados em baias individuais tipo tie-stall, medindo 1,05 m de largura e 2,10 m de comprimento (ajustável), providas de comedouro e bebedouro automático, com piso emborrachado e canaleta com caixa coletora de fezes. Os animais foram pesados no início e final de cada período experimental sendo suplementados com injeção intramuscular de complexo vitamínico (ADEK), seguindo dosagem recomendada pelo fabricante. 
Tabela 4. Composição das forragens ensiladas nos silos tipo poço, submetidas a teores de matéria seca e tamanho de partículas na ensilagem

\begin{tabular}{|c|c|c|c|c|}
\hline \multirow[b]{2}{*}{ Variáveis $^{1}$} & \multirow[b]{2}{*}{$\begin{array}{l}\text { Milheto } \\
\text { grão }\end{array}$} & \multicolumn{3}{|c|}{ Forragens } \\
\hline & & $\begin{array}{l}\text { Original } \\
\text { P. menor }\end{array}$ & $\begin{array}{l}\text { Original } \\
\text { P. maior }\end{array}$ & $\begin{array}{c}\text { Emurchecido } \\
\text { P. maior }\end{array}$ \\
\hline MS, \% & 88,4 & 21,1 & 19,3 & 26,9 \\
\hline $\mathrm{CZ}, \% \mathrm{MS}$ & 2,4 & 11,5 & 11,2 & 10,7 \\
\hline $\mathrm{PB}, \% \mathrm{MS}$ & 14,8 & 8,8 & 7,9 & 7,4 \\
\hline FDN, \%MS & 15,9 & 69,2 & 70,6 & 72,1 \\
\hline FDA, \%MS & 6,8 & 46,9 & 49,5 & 47,0 \\
\hline LIG, \%MS & 2,1 & 5,3 & 5,8 & 5,5 \\
\hline HEMI, \%MS & 7,9 & 22,6 & 22,4 & 24,3 \\
\hline CEL, \%MS & 4,8 & 41,1 & 42,5 & 41,5 \\
\hline $\mathrm{N}-\mathrm{FDA}, \% \mathrm{~N}$ total & 21,4 & 17,1 & 15,5 & 17,0 \\
\hline $\mathrm{CS}, \% \mathrm{MS}$ & & 4,6 & 4,9 & 2,4 \\
\hline CE $\left(\mathrm{mS} . \mathrm{cm}^{-1}\right)$ & & 1,4 & 1,4 & 1,4 \\
\hline Partícula (cm) & & 3,1 & 3,2 & 3,3 \\
\hline $\mathrm{pH}$ & & 6,0 & 6,1 & 6,4 \\
\hline PT (meq.100g MS ${ }^{-1}$ ) & & 23,1 & 20,6 & 20,1 \\
\hline
\end{tabular}

As rações experimentais foram formuladas com base na composição da matéria seca, segundo o NRC (1996), para conter 53\% de NDT e 9\% de PB, visando a manutenção de peso ou ganhos marginais nos animais.

Como o objetivo foi avaliar o comportamento ingestivo dos animais recebendo as silagens, houve a participação de $86,71 \%$ de silagem e apenas $13,29 \%$ de concentrado, veiculando a mistura mineral. O milheto utilizado na composição do concentrado apresentava-se finamente moído. 
Exceção foi para o tratamento T7, no qual apenas foram fornecidos sal e uréia, considerando o milheto presente, adicionado no momento da ensilagem. A proporção de ingredientes na ração oferecida durante o experimento encontra-se na Tabela 5.

Tabela 5. Proporção dos ingredientes nas rações oferecidas aos animais durante o período experimental

\begin{tabular}{lcc}
\hline & \multicolumn{2}{c}{$\%$ da matéria seca } \\
Ingredientes & T1 ao T6 & T7 \\
\hline Silagem de gramínea & 86,6 & 98,2 \\
Milheto grão moído & 11,6 & - \\
Premix mineral* & 1,2 & 1,2 \\
Uréia & 0,6 & 0,6 \\
* Suplemento mineral para bovinos de corte Qualimix ${ }^{\circledR} ;$ Composição (por kg): $6,00 \%$ Ca; 4,00 \\
\% P; 1,61 \% K; 3,70\% S; 8,00 \% Na; 12,05 \% Cl; 5,00 \% Mg; 15 ppm Co; 800 ppm Cu; 20 ppm \\
I; 3100 ppm Fe; 2850 ppm Mn; 20 ppm Se; 3500 ppm Zn; 200000 UI Vit. A; 25000 UI Vit. D; \\
1800 UI Vit. E.
\end{tabular}

A adição de milheto grão moído, no momento da ensilagem, foi realizada com o objetivo de elevar o teor de matéria seca da massa para próximo de $30 \%$ no tratamento $\mathrm{T} 7$, adicionando-se para isto a quantidade necessária. No entanto, ao formular a ração foi estabelecido que a quantidade de milheto necessária para a manutenção dos animais seria uma quantidade inferior àquela presente no $\mathrm{T7}$.

Por isso, mesmo este tratamento não recebendo milheto no momento do fornecimento, a quantidade de cereal presente excedeu aquela determinada pela formulação, de modo que o consumo de milheto neste tratamento foi superior aos demais.

No momento do fornecimento das rações os volumosos e os concentrados, nas suas respectivas proporções, foram pesados e 
homogeneizados para cada animal individualmente e fornecida a ração completa duas vezes ao dia, sendo $60 \%$ da ração fornecida às 8 horas e $40 \%$ às 18 horas. Foi adotado este procedimento com base no comportamento ingestivo observado durante o período de adaptação.

A quantidade fornecida permitiu entre 5 e $10 \%$ de sobras. A ração fornecida e as sobras foram quantificadas diariamente para posterior cálculo de consumo de matéria seca.

$\mathrm{Na}$ Tabela 6 são apresentadas as composições das silagens utilizadas e na Tabela 7 as composições das rações completas.

\subsubsection{Amostragem dos alimentos e das sobras e análises realizadas}

Durante os sete dias do período de coleta três amostras de silagem foram coletadas diariamente, identificadas e congeladas $\left(-20^{\circ} \mathrm{C}\right)$. Foram posteriormente processadas para a realização de análises químicobromatológica, determinação do tamanho médio de partículas em peneiras e para a obtenção do extrato aquoso.

As sobras foram quantificadas para ajuste do fornecimento e amostradas. O milheto que fez parte do concentrado também foi amostrado durante os dias do período de coleta.

As silagens de cada tratamento, as sobras e o milheto, amostrado diariamente, foram agrupados em amostras compostas em cada período de coleta.

\subsubsection{Análises químico-bromatológicas}

Uma das três amostras coletadas foi descongelada, homogeneizada e levada à estufa de ventilação forçada a $60^{\circ} \mathrm{C}$ (Silva, 1981) por 72 horas, para determinação do teor de matéria seca, então foi moída através de peneira de $1 \mathrm{~mm}$ para posteriores análises. 
Tabela 6. Médias das variáveis de composição bromatológica observadas para ingredientes utilizados nas rações

\begin{tabular}{|c|c|c|c|c|c|c|c|c|c|c|}
\hline \multirow[b]{2}{*}{ Variáveis $^{4}$} & \multicolumn{9}{|c|}{ Silagens $^{1,3}$} & \multirow[b]{2}{*}{$\mathrm{CV}^{2}$} \\
\hline & Milheto & $\mathrm{T} 1$ & $\mathrm{~T} 2$ & T3 & $\mathrm{T} 4$ & T5 & T6 & $\mathrm{T7}$ & Média & \\
\hline MS, \% & 88,4 & $22,0^{b}$ & $21,9^{b}$ & $30,8^{a}$ & $30,1^{a}$ & $21,7^{b}$ & $21,5^{b}$ & $30,0^{a}$ & 25,4 & 7,6 \\
\hline PB, \% MS & 14,8 & $5,8^{b}$ & $6,1^{b}$ & $6,1^{b}$ & $5,7^{\mathrm{b}}$ & $5,7^{b}$ & $5,2^{b}$ & $10,5^{a}$ & 6,4 & 16,8 \\
\hline $\mathrm{CZ}, \% \mathrm{MS}$ & 2,4 & $12,8^{a}$ & $12,3^{a}$ & $12,2^{\mathrm{a}}$ & $12,5^{a}$ & $12,6^{\mathrm{a}}$ & $12,3^{a}$ & $7,9^{b}$ & 11,8 & 5,8 \\
\hline FDN, \% MS & 15,9 & $73,5^{a}$ & $74,5^{a}$ & $73,5^{a}$ & $73,2^{\mathrm{a}}$ & $74,0^{a}$ & $74,1^{\mathrm{a}}$ & $42,5^{b}$ & 69,3 & 4,4 \\
\hline FDA, \% MS & 6,8 & $51,2^{a}$ & $52,0^{a}$ & $50,5^{a}$ & $51,5^{a}$ & $52,2^{a}$ & $51,4^{a}$ & $30,1^{b}$ & 48,4 & 5,1 \\
\hline LIG, \% MS & 2,1 & $6,9^{\mathrm{a}}$ & $7,0^{\mathrm{a}}$ & $6,4^{\mathrm{a}}$ & $6,2^{\mathrm{a}}$ & $7,27^{\mathrm{a}}$ & $6,3^{\mathrm{a}}$ & $3,7^{b}$ & 6,2 & 10,6 \\
\hline CEL, \% MS & 7,9 & $44,8^{a}$ & $45,7^{a}$ & $44,6^{a}$ & $45,4^{a}$ & $45,3^{a}$ & $45,8^{a}$ & $26,7^{b}$ & 42,6 & 4,9 \\
\hline HEMI, \% MS & 4,8 & $22,2^{\mathrm{a}}$ & $22,7^{a}$ & $23,2^{a}$ & $22,7^{a}$ & $22,5^{a}$ & $23,5^{a}$ & $12,5^{b}$ & 21,3 & 7,3 \\
\hline $\mathrm{pH}$ & 21,4 & $5,6^{a b}$ & $5,6^{\mathrm{ab}}$ & $6,4^{\mathrm{ab}}$ & $6,8^{\mathrm{a}}$ & $5,9^{\mathrm{ab}}$ & $5,6^{\mathrm{ab}}$ & $5,2^{b}$ & 5,9 & 11,4 \\
\hline Partícula, cm & - & $4,4^{a}$ & $4,2^{a}$ & $4,3^{a}$ & $4,4^{a}$ & $4,3^{a}$ & $4,2^{\mathrm{a}}$ & $3,0^{b}$ & 4,1 & 4,7 \\
\hline Retido na peneira superior, $\%$ & - & $90,9^{a}$ & $85,7^{a}$ & $90,0^{a}$ & $91,2^{a}$ & $89,2^{a}$ & $87,1^{a}$ & $59,5^{b}$ & 84,5 & 5,6 \\
\hline $\mathrm{N}-\mathrm{FDA}, \% \mathrm{~N}$ total & - & $21,7^{\mathrm{a}}$ & $21,6^{\mathrm{ab}}$ & $18,7^{\mathrm{b}}$ & $18,3^{b}$ & $22,1^{a}$ & $20,8^{\mathrm{ab}}$ & $11,6^{c}$ & 19,2 & 8,4 \\
\hline CS, \% MS & - & $0,6^{b}$ & $0,6^{b}$ & $0,9^{a b}$ & $1,6^{\mathrm{a}}$ & $0,6^{\mathrm{b}}$ & $0,6^{b}$ & $1,5^{\mathrm{a}}$ & 0,9 & 39,4 \\
\hline
\end{tabular}

${ }^{1} \mathrm{~T} 1$ - Umidade original, partícula menor, sem inoculante bacteriano; T2 - Umidade original, partícula menor, com inoculante bacteriano;T3 Emurchecido, partícula maior, com inoculante bacteriano; T4 - Emurchecido, partícula maior, sem inoculante bacteriano; T5 - Umidade original, partícula maior, com inoculante bacteriano; T6 - Umidade original, partícula maior, sem inoculante bacteriano; T7 - Umidade original, partícula maior, sem inoculante bacteriano, com milheto.

${ }^{2}$ coeficiente de variação (\%); ${ }^{3}$ Médias na mesma linha, seguidas por letras diferentes, diferem entre si pelo teste de Tukey $(P<0,05)$.

${ }^{4} \mathrm{MS}=$ matéria seca; $\mathrm{CZ}$ = cinzas; $\mathrm{PB}=$ proteína bruta; FDN = fibra em detergente neutro; FDA = fibra em detergente ácido; LIG = lignina; $\mathrm{HEMI}=$ hemicelulose; $\mathrm{CEL}$ = celulose; $\mathrm{MO}$ = matéria orgânica; $\mathrm{CS}=$ carboidratos solúveis; NFDA = nitrogênio insolúvel em FDA. 
Tabela 7. Médias das variáveis de composição bromatológica observadas para as rações completas à base de silagens de capim Tanzânia

\begin{tabular}{|c|c|c|c|c|c|c|c|c|c|}
\hline \multirow[b]{2}{*}{ Variáveis $^{4}$} & \multicolumn{7}{|c|}{ Rações completas $^{1,3}$} & \multirow[b]{2}{*}{ Média } & \multirow[b]{2}{*}{$\mathrm{CV}^{2}$} \\
\hline & $\mathrm{T} 1$ & $\mathrm{~T} 2$ & T3 & $\mathrm{T} 4$ & T5 & T6 & T7 & & \\
\hline MS, \% & $31,1^{b}$ & $30,9^{b}$ & $38,6^{a}$ & $37,9^{a}$ & $30,8^{b}$ & $30,5^{b}$ & $31,2^{b}$ & 33,0 & 5,7 \\
\hline $\mathrm{PB}, \% \mathrm{MS}$ & $8,3^{b}$ & $8,6^{b}$ & $8,5^{\mathrm{b}}$ & $8,2^{b}$ & $8,2^{b}$ & $7,7^{\mathrm{b}}$ & $11,9^{a}$ & 8,8 & 12,0 \\
\hline $\mathrm{CZ}, \% \mathrm{MS}$ & $12,6^{a}$ & $12,1^{a}$ & $12,0^{\mathrm{a}}$ & $12,3^{a}$ & $12,3^{\mathrm{a}}$ & $12,1^{\mathrm{a}}$ & $8,9^{b}$ & 11,8 & 5,3 \\
\hline FDN, \% MS & $65,6^{a}$ & $66,5^{a}$ & $65,6^{a}$ & $65,4^{a}$ & $66,1^{a}$ & $66,2^{\mathrm{a}}$ & $41,7^{b}$ & 62,4 & 4,7 \\
\hline FDA, \% MS & $45,2^{a}$ & $45,9^{a}$ & $44,6^{a}$ & $45,5^{a}$ & $46,0^{a}$ & $45,4^{a}$ & $29,6^{b}$ & 43,2 & 5,5 \\
\hline LIG, \% MS & $6,2^{\mathrm{a}}$ & $6,3^{\mathrm{a}}$ & $5,8^{\mathrm{a}}$ & $5,6^{\mathrm{a}}$ & $6,5^{\mathrm{a}}$ & $5,7^{\mathrm{a}}$ & $3,7^{b}$ & 5,7 & 10,6 \\
\hline CEL, \% MS & $39,4^{a}$ & $40,2^{a}$ & $39,3^{a}$ & $40,0^{a}$ & $39,9^{a}$ & $40,3^{a}$ & $26,2^{b}$ & 37,9 & 5,3 \\
\hline HEMI, \% MS & $20,1^{a}$ & $20,6^{a}$ & $21,1^{a}$ & $20,6^{a}$ & $20,4^{a}$ & $21,3^{\mathrm{a}}$ & $12,3^{b}$ & 19,5 & 7,2 \\
\hline $\mathrm{MO}, \% \mathrm{MS}$ & $87,4^{\mathrm{a}}$ & $87,9^{\mathrm{a}}$ & $88,0^{\mathrm{a}}$ & $87,7^{\mathrm{a}}$ & $87,7^{\mathrm{a}}$ & $87,9^{\mathrm{a}}$ & $91,1^{\mathrm{a}}$ & 88,2 & 0,7 \\
\hline
\end{tabular}

${ }^{1}$ T1 - Umidade original, partícula menor, sem inoculante bacteriano; T2 - Umidade original, partícula menor, com inoculante bacteriano;T3 Emurchecido, partícula maior, com inoculante bacteriano; T4 - Emurchecido, partícula maior, sem inoculante bacteriano; T5 - Umidade original, partícula maior, com inoculante bacteriano; T6 - Umidade original, partícula maior, sem inoculante bacteriano; T7 - Umidade original, partícula maior, sem inoculante bacteriano, com milheto.

${ }^{2}$ coeficiente de variação (\%); ${ }^{3}$ Médias na mesma linha, seguidas por letras diferentes, diferem entre si pelo teste de Tukey $(P<0,05)$.

${ }^{4} \mathrm{MS}=$ matéria seca; $\mathrm{CZ}$ = cinzas; $\mathrm{PB}=$ proteína bruta; FDN = fibra em detergente neutro; FDA = fibra em detergente ácido; $L \mathrm{LIG}=$ lignina; $\mathrm{HEMI}=$ hemicelulose; $\mathrm{CEL}$ = celulose; $\mathrm{MO}=$ matéria orgânica; $\mathrm{CS}=$ carboidratos solúveis; NFDA = nitrogênio insolúvel em FDA 
Devido ao grande número de amostras geradas a determinação da composição químico-bromatológica das amostras de forragem, silagens e milheto foi realizada utilizando-se o método de espectroscopia de reflectância de infravermenlho proximal (NIRS) (Berzaghi et al., 1997; Shenk \& Westernhaus, 1991; Mathison et al., 1999 Cozzolino et al., 2001), visando a redução no número de amostras e otimização tanto o tempo como dos custos de análises.

O material moído foi escaneado para obtenção dos espectros NIRS. O equipamento utilizado foi o espectrômetro modelo NIRS 5000 (NIRSystems ${ }^{\circledR}$, Silver Spring, MD, USA) acoplado a um microcomputador equipado com softwear WinISI II versão 6.2 (Intrasoft International, PA), com dois tipos de células de leitura para escanear as amostras: quando estas apresentavam quantidades suficientes, foi utilizada a célula modelo Transport quarter cup (código IH - 0379), caso contrário, utilizou-se a de modelo Micro sample cup (código IH - 0348).

As amostras foram escaneadas nesse equipamento obtendo leituras compreendidas entre os comprimentos de onda de 700 a $2100 \mathrm{~nm}$. Esses espectros foram armazenados em curvas log, ( $1 / R$, onde $R$ é o valor da reflectancia) em intervalo de $2 \mathrm{~nm}$. Utilizaram-se os métodos de seleção de amostras existentes no softwear do equipamento, descartando-se as amostras distantes mais de $3 \mathrm{H}$ (distância padronizada de Mahalanobis) da média, tidas como outliers.

Adotou-se uma distância mínima de 0,6 H entre amostras para seleção daquelas em que seriam efetuadas as análises bromatológicas convencionais, ou seja, onde o valor outlier $(\mathrm{H})$ é usado para eliminar amostras com distâncias espectrais muito afastadas da média da população (Shenk \& Westernhaus, 1991; Mathison et al., 1999).

O procedimento realizado pelo programa é o seguinte: as amostras para calibração foram selecionadas espectralmente usando o sub-programa ISI SELECT (Shenk \& Westernhaus, 1991), que começa identificando o espectro 
representativo de espectros vizinhos, mantendo este e descartando os demais. Então, o programa avalia todas as amostras remanescentes e repete o procedimento até que só reste o mínimo possível de amostras.

$\mathrm{O}$ procedimento SELECT usa uma distância $\mathrm{H}$, padronizada entre pares de amostras para definir vizinhanças, e baseia-se na suposição de que somente uma amostra seja requerida para representar todas as amostras contidas naquele grupo de vizinhança.

Quanto mais heterogêneo for o grupo de amostras escaneadas maior deverá ser o número de amostras selecionadas para cobrir toda amplitude espectral (Mathison et al., 1999).

Nas amostras selecionadas foram realizadas análises convencionais ou métodos de referência (Berzaghi et al., 1997) do teor CZ (AOAC, 1980). Análises do teor de PB, foram obtidas através da combustão das amostras segundo o método de Dumas, utilizando-se um auto-analisador de nitrogênio, marca LECO ${ }^{\circledR}$, modelo FP-528 (Wiles et al., 1998).

Teores de fibra insolúvel em detergente neutro (FDN) foram obtidos através do método proposto pela ANKOM Fiber Analyser (ANKOM Technology Corporation, Fairport, NY). Os teores de fibra insolúvel em detergente ácido (FDA) e lignina (LIG) foram calculados segundo método de Van Soest et al. (1991). Análises de nitrogênio na fibra insolúvel em detergente ácido (N-FDA) foram realizadas seguindo metodologia proposta por Krishnamoorthy et al. (1982).

Após análise química convencional, seus valores foram inseridos no banco de dados e permitiram ao softwear do programa NIRS predizer o valor das demais amostras não analisadas. Então, foram utilizados métodos estatísticos existentes no softwear do NIRS para o desenvolvimento de equações de predição dos teores dos componentes da análise químicobromatólógica para o total de amostras. 


\subsubsection{Extrato aquoso}

De outra amostra, mantida com umidade original, foi obtido o extrato aquoso (Kung Junior et al., 1984), no qual foi registrado o valor de $\mathrm{pH}$ e determinados o teor de carboidratos solúveis (Dubois et al., 1956), com leitura em 490 nm, e a concentração de $\mathrm{N}-\mathrm{NH}_{3}$ (Chaney \& Marbach, 1962), com leitura em 550nm, ambos lidos em espectrofotômetro JENWAY-6405 UV/VIS ${ }^{\circledR}$.

\subsubsection{Determinação do tamanho de partícula}

Numa terceira amostra composta para cada tratamento por período foi feita avaliação do tamanho de partículas com base na metodologia da estratificação em peneiras utilizando o PennState Particle Size Separator (Lammers et al., 1996), definindo-se a proporção de material que ficou retido em cada peneira, ou seja, acima de $1,90 \mathrm{~cm}$, entre 1,90 e 0,78 cm e abaixo de $0,78 \mathrm{~cm}$.

\subsubsection{Atividades durante o período de avaliação}

\subsubsection{Comportamento ingestivo}

No primeiro dia de cada período de avaliação, os animais foram observados por um período de 24 horas, iniciando-se após o fornecimento da ração (8:00 h).

Anotou-se, em uma planilha, a cada 5 minutos, a atividade realizada pelo animal naquele momento, sendo: ingestão de alimento, ingestão de água, ruminação ou ócio (Maekawa et al., 2002).

A fim de não haver interferência da luz no comportamento animal, durante o período noturno, apagaram-se as luzes das instalações e o 
observador contou apenas com o auxílio de uma lanterna para fazer as observações, emitindo luz indiretamente para a observação do animal.

Para a realização dos cálculos na avaliação do comportamento multiplicou-se o número de observações que cada animal apresentou em cada atividade (ingestão de alimento ou água, ruminação e ócio) por 5 (minutos), assumindo que nos próximos 5 minutos pós observação o animal permaneceu na mesma atividade.

Então, as atividades foram distribuídas proporcionalmente pelo período de 1440 minutos, ou seja, 24 horas de observação.

O tempo de mastigação total foi determinado somando-se o tempo de ingestão de alimento com o tempo de ruminação (Maekawa et al., 2002; Kononoff et al., 2003).

A partir das observações e dos dados de ingestão (kg MS e kg FDN) foram calculadas as taxas de ingestão, ruminação e mastigação, tanto para MS quanto para FDN, assim como estabelecido o tempo em ócio ou ingerindo água (minutos.dia ${ }^{-1}$ ).

Os cálculos das taxas de ingestão, ruminação e mastigação da matéria seca foram estimados dividindo-se a quantidade de matéria seca ingerida $(\mathrm{kg})$ pelo tempo, em minutos, para cada atividade.

A obtenção das taxas de ingestão, ruminação e mastigação da FDN e da MS foram estimadas pela multiplicação das respectivas taxas pela concentração dos componentes na matéria seca efetivamente ingerida pelos animais.

\subsubsection{Determinação do desaparecimento intestinal através da técnica de sacos móveis}

No segundo dia de cada período foram inseridos, através da cânula duodenal, 14 sacos de náilon $(3,5 \times 5,0 \mathrm{~cm})$, contendo aproximadamente 0,6 gramas de alimento seco e moído em $2 \mathrm{~mm}$, sendo sete sacos com silagem na 
sua composição original e sete sacos com a silagem pré-degradada no rúmen por 12 horas (Vanhatalo \& Ketoja, 1995).

Após a introdução do primeiro saco móvel no primeiro animal procediase à colocação do primeiro saco em outro animal, de modo que, até o momento de retornar ao animal que havia recebido o primeiro saco de náilon, o tempo decorrido auxiliava na passagem deste para porções posteriores do intestino.

Durante as 48 horas subseqüentes estes foram recuperados nas fezes, lavados, secos em estufa de ventilação forçada a $60^{\circ} \mathrm{C}$ (Silva, 1981), por 72 horas, e pesados para quantificação de seu resíduo.

\subsubsection{Parâmetros ruminais}

No terceiro dia do período de coleta, amostras de líquido ruminal $( \pm 100$ $\mathrm{mL}$ ) foram tomadas diretamente de vários pontos ventrais do rúmen.

A primeira amostragem ocorreu imediatamente antes da oferta de alimento matinal (8 horas) e as amostras subseqüentes foram sendo coletadas a cada 2 horas, por um período de 24 horas, sendo os tempos estabelecidos de $0,2,4,6,8,10,12,14,16,18,20$ e 22 horas.

A digesta tomada do rúmen foi filtrada em tecido de algodão, coletando-se o líquido em um copo plástico e devolvendo a parte sólida ao rúmen. Imediatamente o líquido ruminal foi homogeneizado e seu valor de $\mathrm{pH}$ mensurado através da leitura em potenciômetro DIGIMED ${ }^{\circledR}-$ DMPH2.

Então tomaram-se duas alíquotas de $50 \mathrm{~mL}$ deste líquido ruminal, que foram congeladas em freezer $\left(-20^{\circ}\right)$, em dois recipientes plásticos separados, para posteriores análises de nitrogênio amoniacal $\left(\mathrm{N}-\mathrm{NH}_{3}\right)$ e ácidos graxos voláteis (AGV).

Após o descongelamento de um dos recipientes, aproximadamente 12 $\mathrm{mL}$ do líquido foram colocados em tubo e centrifugados a $12000 \times \mathrm{g}$, a $4^{\circ} \mathrm{C}$, durante 20 minutos. $\mathrm{Na}$ fração sobrenadante determinou-se $\mathrm{N}-\mathrm{NH}_{3}$, seguindo o 
método colorimétrico proposto por Chaney \& Marbach (1962), executando as leituras em espectrofotômetro JENWAY-6405 UV/VIS ${ }^{\circledR}$, em 550 nm.

Para a determinação dos AGV o outro recipiente de líquido ruminal foi descongelado e $12 \mathrm{~mL}$ foram centrifugados a $12000 \times \mathrm{g}$, a $4^{\circ} \mathrm{C}$, por 60 minutos. Tomou-se $0,8 \mathrm{~mL}$ de sobrenadante, o qual foi colocado em frasco para leitura juntamente com $0,2 \mathrm{~mL}$ de ácido metafosfórico e $0,1 \mathrm{~mL}$ de padrão interno, mantendo-o congelado. No momento da realização das leituras, estes frascos foram descongelados em temperatura ambiente e realizadas as leituras em cromatrógrafo líquido gasoso, CLG (Hewlett Packard ${ }^{\circledR} 5890$, series II), equipado com HP Integrator 3396, série II (Hewlett Packard Company ${ }^{\circledR}$, Avondale, PA). O gás de arraste e os comburentes foram nitrogênio, hidrogênio e oxigênio, respectivamente, nas vazões de 20,30 e $400 \mathrm{~mL} \mathrm{~min}{ }^{-1}$. As temperaturas do injetor, do detector e da coluna foram de 150, 190 e $115^{\circ} \mathrm{C}$, respectivamente.

Como padrão interno foi utilizada a solução do ácido 2-etilbutírico, tomando-se 1,1615 $\mathrm{ml}$ deste e diluindo-o em $10 \mathrm{ml}$ de etanol e água deionizada. A cada 10 frascos com amostras colocadas no equipamento para serem lidas, um padrão externo com concentrações conhecidas de ácidos de interesse foi introduzido, sendo que a diferença entre as concentrações conhecidas destes ácidos e suas leituras gerou um fator de correção aplicado às outras amostras (Palmquist \& Conrad, 1971).

\subsubsection{Determinação da taxa de passagem}

A taxa de passagem foi determinada com o uso de Co-EDTA e fibra marcada com cromo mordante obtidas segundo metodologia proposta por Udén et al. (1980), como marcadores de fases líquida e sólida, respectivamente, quantificados posteriormente nas fezes.

No quarto dia do período estes marcadores foram administrados aos animais. Antes da alimentação matutina, $3 \mathrm{~g}$ de Co-EDTA foram diluídos em 
$1000 \mathrm{~mL}$ de água e infundidos no interior do rúmen através de mangueira plástica.

Simultaneamente, $100 \mathrm{~g}$ de fibra marcada com cromo mordante foram também introduzidos no rúmen via cânula ruminal, em vários pontos. Esta fibra marcada foi preparada com antecedência, de modo que cada animal recebeu fibra marcada da respectiva silagem que estava sendo fornecida a ele naquele período.

Amostras de fezes foram coletadas diretamente do reto dos animais nos tempos $0,6,12,18,14,30,36,42,48,54,60,66,72,78,84$ e 90 horas após o fornecimento dos marcadores. As amostras foram pesadas, secas imediatamente, em estufa de ventilação forçada a $60^{\circ} \mathrm{C}$ (Silva, 1981), e então moídas em $1 \mathrm{~mm}$ para posteriores análises dos marcadores.

A quantificação dos elementos foi realizada através da técnica analítica denominada fluorescência de raios $X$ por dispersão de energia (EDXRF, energy dispersive X-ray fluorescence), no Laboratório de Instrumentação Nuclear, da Divisão de Desenvolvimento de Métodos e Técnicas Analíticas e Nucleares, do CENA/USP (Nascimento Filho, 1999).

Os dados das leituras foram expressos em ppm, mas para efeito de cálculos foram transformados para a base de logaritmo neperiano e plotados contra os tempos de coleta, criando-se uma curva. A partir da maior leitura (pico), determinou-se a porção linear da curva descrita pelos valores de Ln [Co] e $\mathrm{Ln}[\mathrm{Cr}]$ e desta, obteve-se o coeficiente angular $\left(\operatorname{tg} \alpha=(\Delta \mathrm{y} / \Delta \mathrm{x})^{\star} 100\right)$ que representou a taxa de passagem (Firkins et al., 1986).

\subsubsection{Coleta de amostras para determinação da digestibilidade aparente}

Os valores de digestibilidade dos nutrientes foram estimados através da diferença entre as concentrações de nutrientes presentes na ração consumida e nas fezes. 
Durante os últimos quatro dias do período de avaliação, as fezes foram retiradas da caixa coletora, duas vezes ao dia (8 e $20 \mathrm{~h}$ ), pesadas, homogeneizadas e amostradas em $5 \%$ do total excretado, que foi sendo congelado para formar uma amostra composta por tratamento, em cada período experimental. Ao peso destas fezes foram somadas as fezes coletadas no reto para determinação dos marcadores. O cálculo foi realizado conforme Equação 4 (Rymer, 2000) a seguir:

$$
\text { Digestibilidade }=\underline{(\text { Oferecido }- \text { Sobras })-\text { Fezes }} \times 100
$$

(Oferecido - Sobras)

Após serem descongeladas e homogeneizadas, as fezes compostas foram levadas à estufa de ventilação forçada a $60^{\circ} \mathrm{C}$ (Silva, 1981) por 72 horas, para determinação da matéria seca, e então moídas em $1 \mathrm{~mm}$ para posteriores análises laboratoriais de composição bromatológica.

Após ter sido determinada a matéria seca em $105^{\circ} \mathrm{C}$, realizou-se análise do teor CZ (AOAC, 1980); análise do teor de PB, obtido através da combustão das amostras, segundo o método de Dumas, utilizando-se um autoanalisador de nitrogênio, marca LECO ${ }^{\circledR}$, modelo FP-528 (Wiles et al., 1998).

Teores de FDN foram obtidos através do método proposto pela ANKOM Fiber Analyser (ANKOM Technology Corporation, Fairport, NY) e teores de FDA e lignina foram calculados segundo método de Van Soest et al. (1991).

\subsubsection{Determinação da degradabilidade in situ}

Para a avaliação da degradação ruminal utilizaram-se sacos de náilon medindo 9,5 x $13 \mathrm{~cm}$ de área útil, inseridos no rúmen em triplicata para cada tratamento e horário de incubação. 
Durante cada período de adaptação, as respectivas silagens foram secas, em estufa de ventilação forçada a $60^{\circ} \mathrm{C}$ (Silva, 1981), por 72 horas e moídas em 2 mm para serem introduzidas nos sacos de náilon.

Os sacos de náilon tiveram seu peso vazio registrado e aproximadamente $6 \mathrm{~g}$ de silagem foram colocados em cada saco de náilon. Os sacos foram presos por uma argola a um mosquetão e este preso a uma corrente, que ficou imersa no conteúdo ruminal. A corrente ficava presa a um pedaço de madeira ou tubo plástico, através de uma corda, ancorando-a, e que servia para puxar o conjunto para fora do rúmen.

Foram adotados seis tempos de incubação ruminal: 96, 48, 24, 12, 6 e 0 horas. Iniciou-se a incubação pela ordem inversa de modo que todos foram retirados de uma só vez, com exceção do tempo 0 hora, que não foi incubado. Ao serem retirados do rúmen, os sacos permaneciam em um grande balde plástico, lavados em água corrente. No momento da lavagem os sacos do tempo 0 hora foram lavados juntamente. Quando a água começou a sair limpa, então foram retirados, apertados levemente para retirar o excesso de água e levados para a estufa de ventilação forçada a $60^{\circ} \mathrm{C}$ (Silva, 1981) por 72 horas.

Após os sacos secos terem sido pesados individualmente, quantificando o resíduo, para posterior cálculo da taxa de desaparecimento de matéria seca, os resíduos das triplicatas de cada horário foram agrupados, formando uma amostra composta que foi moída a $1 \mathrm{~mm}$ para posterior análise.

As amostras dos resíduos de degradação ruminal também foram escaneadas no NIRS, mas compondo um grupo separado das amostras de forragens, silagens, sobras e concentrados. O procedimento executado foi o mesmo citado no ítem 4.2.5.1.

Após os teores dos componentes da análise químico-bromatólógica terem sido estimados para o total de amostras escaneadas, os dados das amostras incubadas in situ foram processados utilizando o programa Fit Curve desenvolvido pela Rowett Research Institute, Aberdeen, Escócia (http://www.mluri.sari.ac.uk/IFRU/fcurve.html). 
O programa oferece os parâmetros do modelo de degradabilidade ruminal segundo Orskov \& McDonald (1979), entre outras informações. As degradabilidades potenciais (DP) in situ de MS, FDN, FDA e hemicelulose foram calculadas de acordo com a Equação 5:

$$
D P=a+b\left(1-e^{-c t}\right)
$$

DP = degradabilidade potencial estimada, \%;

$a=$ interseção da curva no tempo 0 , podendo ser interpretada como fração rapidamente solúvel, \% do original;

b = fração insolúvel em água, mas potencialmente degradável, \% do original;

$c=$ taxa de degradação da fração "b" por hora, $\% \cdot \mathrm{h}^{-1}$;

e = logaritmo natural;

$\mathrm{t}=$ tempo de incubação, $\mathrm{h}$;

$\mathrm{a}+\mathrm{b}=$ potencial de degradabilidade, $\%$.

A degradabilidade potencial é dada pela soma das frações "a" e "b", como sendo a quantidade de material que pode ser perdido por degradação e em solução se o tempo de incubação for infinito, ou seja, desconsiderando-se a taxa de passagem que ocorre no rúmen.

A degradabilidade efetiva (DE) foi calculada pela equação de Orskov \& McDonald (1979), Equação 6:

$D E=a+\left(b\left(1 \times c^{-c+k p}\right)\right)$

DE = degradabilidade efetiva, \%;

$a=$ interseção da curva no tempo 0 , podendo ser interpretada como fração rapidamente solúvel, \% do original;

b = fração insolúvel em água, mas potencialmente degradável, \% do original; 
$c$ = taxa de degradação da fração "b" por hora, $\% \mathrm{~h}^{-1}$;

$\mathrm{T}=$ tempo de colonização ou lag time, $\mathrm{h}$;

$\mathrm{k}=$ taxa de passagem da fase sólida, \%.

\subsubsection{Análise estatística}

O delineamento experimental adotado foi o Quadrado Latino $7 \times 7$, com sete tratamentos e sete períodos de avaliação. No entanto, alguns tratamentos foram interrompidos antes de completar todos os períodos. No período 5 somente foram avaliados os tratamentos T1, T2, T3, T5 e T7, no período 6 somente os tratamentos T1, T5 e T7 e no período 7 os tratamentos T1, T2 e T7. Nesses casos foram considerados como parcelas perdidas.

Os dados foram analisados utilizando-se o programa estatístico SAS ${ }^{\circledR}$, versão 6.12 para Windows ${ }^{\circledR}$ (SAS, 1996).

Para comparação das médias na avaliação do consumo, digestibilidade, composição das silagens e das dietas, comportamento ingestivo, taxa de passagem, tempo médio de retenção ruminal, degradação ruminal e digestão intestinal foi utilizado o procedimento PROC GLM do SAS. Para parâmetros ruminais como $\mathrm{pH}$, amônia e ácidos graxos voláteis utilizou-se o PROC MIXED, por se tratar de avaliações repetidas no tempo.

O modelo empregado para estimar os parâmetros de degradação ruminal gerou alguns valores negativos para a fração "a" de FDN, FDA e hemicelulose. Como não existe fração "a" negativa foram levantadas duas hipóteses para tentar explicar. A primeira é a que tenha havido incrustação de material durante a lavagem após incubação, elevando o peso do resíduo. Outra explicação é que os desvios, em função de elevado coeficiente de variação da média, no programa Fit curve (Orskov \& McDonald, 1979), estimou valores nulos ou negativos, gerando frações "a" negativas. Associando-se os dois fatores adotou-se o procedimento de substituir estes valores negativos por zero, tentando minimizar estes erros. 


\subsection{Resultados e Discussão}

\subsubsection{Avaliação das rações experimentais}

\subsubsection{Composição químico-bromatológica das silagens e das rações completas}

Os teores dos nutrientes analisados nas amostras compostas das silagens de capim Tanzânia e do milheto, ofertados ao longo do período experimental, assim como a composição químico-bromatológica calculada das rações, encontram-se nas Tabelas 6 e 7, respectivamente (ítem 4.2.4 Período experimental, animais utilizados e rações). As amostras de silagem e de milheto foram analisadas separadamente para garantir maior precisão dos resultados.

A proporção dos ingredientes (\% MS), utilizada para formulação das rações experimentais, foi de $86,6 \%$ de silagem de capim e $13,4 \%$ de concentrado (11,6\% de grão de milheto moído, 1,2 \% de suplemento mineral e $0,6 \%$ de uréia). Com exceção do tratamento T7, no qual foram utilizados $98,2 \%$ de silagem de capim, $1,2 \%$ de suplemento mineral e $0,6 \%$ de uréia, não recebendo milheto no momento do fornecimento uma vez que foi computada a adição desse ingrediente no momento da ensilagem, com o objetivo de elevar o teor de MS.

Devido às elevadas perdas por deterioração que ocorreram nos silos durante o período experimental alguns tratamentos sofreram redução na disponibilidade de silagens e não foram avaliados nos últimos períodos. No período 5 somente foram avaliados os tratamentos T1, T2, T3, T5 e T7, no período 6 somente os tratamentos T1, T5 e T7 e no período 7 avaliou-se os tratamentos T1, T2 e T7. Esse fato pode ter sido causador dos elevados coeficientes de variação observados para algumas variáveis que serão discutidas a seguir. 
Os procedimentos adotados na ensilagem com o objetivo de elevar o teor de MS para próximo de 30\% (T3, T4 e T7) foram eficientes, gerando silagens com teor médio de $30,3 \%$ de $M S$, diferindo $(P<0,05)$ daquelas silagens com teor de umidade original, apresentando teor médio de MS de 21,8\% (Tabela 6).

Pela análise dos dados da Tabela 6 pode ser observado que não houve efeito $(P>0,05)$ de tamanho de partícula, emurchecimento e uso de inoculante bacteriano $(P>0,05)$ sobre as variáveis $P B, C Z$, FDN, FDA, LIG, CEL e HEMI. Parte da falta de resultados referentes ao tamanho de partícula foi devido ao fato que a amplitude de picagem não possibilitou tamanhos de partículas que fossem significativamente diferentes, apesar de ter sido imposto como tratamento na ensilagem através do distanciamento das facas da colhedora.

No entanto, para estes nutrientes, houve efeito da adição de milheto no tratamento $T 7$, com diluição das frações fibrosas e $C Z(P<0,05)$ e elevação do teor de $\mathrm{PB}(\mathrm{P}<0,05)$, devido à contribuição do maior teor protéico do milheto na mistura final $(10,48 \%)$, comportamentos previamente observados por outros autores ao adicionarem ingredientes concentrados ao capim na ensilagem (Crestana et al., 2001; Pedreira et al., 2001).

O valor de PB médio de 5,75\%, em silagens sem adição de milheto (T1 ao T6), encontra-se dentro da amplitude relatada na literatura para silagens de capim Tanzânia que vai de 4,76\% (Loures, 2004) a 6,40\% (Corrêa \& Cordeiro, 2000; Igarasi, 2002). A forragem ensilada no presente experimento continha teor médio de PB de 8,03\% (Tabela 4) enquanto as silagens apresentaram teor médio de PB inferior (5,75\% PB), revelando perda de $28,40 \%$ da PB durante a ensilagem. Comprovou-se que o uso de inoculante bacteriano não foi efetivo em preservar a PB nas silagens desse trabalho, como também havia sido relatado por Coan et al. (2001) em silagens de capins Tanzânia e Mombaça, assim como o emurchecimento também não foi um procedimento efetivo na preservação da PB. 
Os valores de $C Z$ aqui obtidos encontram-se superiores aos $11 \%$ obtidos nas silagens capim Tanzânia, aos 60 dias de idade, como relatado por Crestana et al. (2001). Estes autores verificaram que ao emurchecerem o capim Tanzânia elevaram o teor de CZ de 11,71 para 12,45\%, o mesmo comportamento observado por Loures (2004), alegando que com o emurchecimento perde-se carboidratos solúveis fazendo, com isso, elevar a proporção de $C Z$, além do fato da forragem sem emurchecimento perder parte da $C Z$ através da drenagem por efluente. Contudo, no presente experimento não houve efeito do emurchecimento sobre o teor de $C Z(P>0,05)$.

Um outro fator que pode contribuir para a elevação no teor de $C Z$ da forragem emurchecida é a contaminação com solo, pois a forragem picada é lançada ao solo para a desidratação e exige que seu recolhimento seja realizado com o mecanismo coletor rebaixado, aumentando as chances de captação de solo.

$O$ teor de FDN não foi alterado pelo emurchecimento $(P>0,05)$ apesar de haver relatos que este procedimento poderia elevar o teor desse nutriente, como observado por Igarasi (2002). Embora o contrário também possa ocorrer, gerando-se maior teor de FDN em silagens sem emurchecimento como obtido por Loures (2004).

Valores de FDA $(48,40 \%)$ aqui obtidos estão dentro de valores normalmente obtidos na literatura de $43 \%$ (Loures, 2004) a $49 \%$ (Coan, et al., 2001) para silagens de capim Tanzânia.

Os valores de $\mathrm{pH}$, assim como também demonstrado por Dawson et al. (1999) foram elevados $(P<0,05)$ pelo emurchecimento, atribuindo-se ao fato destas silagens permitirem fermentação mais restrita, produzindo menos ácidos. No presente trabalho o menor $\mathrm{pH}(5,18)$ foi obtido em silagem com adição de milheto grão $(P<0,05)$ e o maior valor de $\mathrm{pH}(6,82)$ em silagem emurchecida $(P<0,05)$, ambas sem inoculante bacteriano, permanecendo os demais tratamentos com valores intermediários $(5,82)$, não diferindo entre si $(P>0,05)$ e nem dos tratamentos T7 e T4 (Tabela 6). O uso do inoculante (T2, 
T3 e T5) não contribuiu para menor valor de pH $(P>0,05)$ em relação às silagens sem inoculante (T1, T4, T6 e T7).

$O$ fato de silagens emurchecidas apresentarem maior valor de carboidratos solúveis (CS) já havia sidoi relatado por Vilela (1998) e, segundo Marsh (1979), o emurchecimento promove perda de carboidrato no campo, pela longa exposição da forragem ceifada à desidratação em condições aeróbicas, no entanto da fração remanescente grande proporção será preservada durante a ensilagem, devido à fermentação mais restrita neste tipo de silagem.

No presente experimento a forragem com umidade original na ensilagem apresentou média de $4,74 \%$ de CS (\% MS) e forragens emurchecidas a média de 2,42\% (Tabela 4), representando redução significativa de $49 \%$ na forragem durante o emurchecimento. No entanto o teor de CS residual (Tabela 6) nas silagens emurchecidas (1,23\% MS) foi maior do que naquelas com umidade original $(0,59 \%$ da $M S)$, concordando com 0 exposto por Marsh (1979).

Os valores de CS aqui obtidos para forragem fresca $(4,74 \%)$ no momento da ensilagem são inferiores aos 8,9\% de Coan et al. (2001) para Tanzânia e abaixo da amplitude de 9 a 16\% observada por Lavezzo (1985) em capim Elefante, confirmando a teoria de que gramíneas tropicais são pobres em CS, podendo comprometer a fermentação (Zierenberg et al., 2001). Segundo Kearney \& Kennedy (1962) os teores médios de CS encontrados para gramíneas tropicais geralmente estão abaixo dos 15\% MS indicados como o mínimo para obtenção de silagens de boa qualidade.

No caso do tratamento com adição de milheto (T7), o teor de CS foi superior $(\mathrm{P}<0,05)$ aos tratamentos com umidade original $(1,53$ vs $0,59 \%$ na MS), não devido à contribuição de carboidrato pelo aditivo mas sim pela redução na umidade das silagens, aumentando a pressão osmótica, inibindo ação microbiana que degradaria o carboidrato presente na forragem, benefício esse também constatado nas silagens emurchecidas, sem adição de material absorvente. 
Aditivos com elevado teor de amido (milho, sorgo, milheto) não contribuem para o aumento do teor de CS, pois o amido não é usado eficientemente pelas bactérias láticas como substrato (Lavezzo, 1985; Pedreira et al.; 2001; Ávila et al., 2003a.,b). Já a polpa cítrica é um aditivo que colabora para aumentar o teor de carboidratos solúveis (Pedreira et al.; 2001; Ávila et al., 2003a, b), além de reduzir a umidade da massa.

Os tamanhos de partículas impostos na ensilagem não foram suficientes para gerar diferenças no tamanho médio de partículas nas silagens ( $P>0,05)$, apresentando média geral de $4,11 \mathrm{~cm}$, com exceção para o T7 que apresentou menor $(P<0,05)$ tamanho médio de partícula devido à contribuição do milheto grão que fez com que mais material permeasse para peneiras inferiores (Lammers et al., 1996) e não pela redução do tamanho da partícula da forragem.

Os maiores valores $(\mathrm{P}<0,05)$ de $\mathrm{N}$-FDA foram observados em silagens com umidade original $(21,5 \% \mathrm{~N}$ total), seguidos pelas emurchecidas com valores intermediários $(18,5 \% \mathrm{~N}$ total) e o menor $(P<0,05)$ foi encontrado em silagem adicionada com milheto (11,58\% $\mathrm{N}$ total).

Waldo (1977) e Heimbeck et al. (2003) sugeriram que o aquecimento ocorrido principalmente em silagens emurchecidas diminui a solubilidade da proteína, reduzindo conseqüentemente sua digestibilidade em até um terço. Assim, baixa proporção de proteína verdadeira, do total de proteína bruta, chegaria ao intestino dos animais que consomem elevadas proporções de silagens de gramíneas.

No entanto, no presente trabalho, o aquecimento não foi o único responsável pelo elevado teor de N-FDA das silagens pois a forragem no momento da ensilagem já apresentava elevado teor, com média de 16,54\% de N-FDA (Tabela 4).

Analisando a composição das rações completas (Tabela 7) pode-se observar que esta seguiu o mesmo comportamento observado para a 
composição das silagens, discutido acima, uma vez que a silagem participou com no mínimo $86,6 \%$ da MS total da ração.

As elevadas perdas por deterioração que ocorreram nessas silagens foram decorrentes de compactação insuficiente no momento do enchimento dos silos. Além de favorecer a deterioração e não permitir que todos os tratamentos fossem avaliados em todos os períodos, esse procedimento inadequado pode ter sido responsável pela ausência de efeitos dos tratamentos, demonstrado através das variáveis discutidas acima.

\subsubsection{Cinética, ingestão e comportamento ingestivo dos animais}

\subsubsection{Ingestão de matéria seca}

Os tratamentos impostos não promoveram diferenças $(P>0,05)$ na ingestão de MS, tanto em $\mathrm{kg}$ de MS (4,50 kg) como na base do peso vivo dos animais (1,10\% PV), cujas médias são apresentadas na Tabela 8. Apesar disso, houve efeito de tratamentos sobre o consumo de FDN, com maiores valores para T2 e T5 $(0,75 \%$ PV), tratamentos estes aditivados com inoculante bacteriano, diferindo $(P<0,05)$ da menor ingestão de FDN ocorrida para 0 tratamento $\mathrm{T} 7(0,50 \% \mathrm{PV})$. Os demais tratamentos (T1, T3, T4 e T6) tiveram valores intermediários $(0,68 \% \mathrm{PV})$ não diferindo das médias acima $(P>0,05)$. $O$ fato do T7 ter apresentado menor ingestão de FDN foi devido à adição de milheto na ensilagem que diluiu o FDN da forragem em comparação aos demais tratamentos.

A ingestão média de 4,5 kg MS.animal.dia ${ }^{-1}$ ficou abaixo da média de 8,6 kg predita pelo NRC (1996). A formulação previa a manutenção ou pequeno ganho de peso mas, como a ingestão foi deprimida, os animais perderam peso durante o período experimental, apresentando pesos médios, inicial e final, de 415 e $407 \mathrm{~kg}$, respectivamente. 
Apesar da porção visualmente deteriorada ter sido separada e descartada no momento do fornecimento, o consumo foi limitado, o que pode ser devido a aspectos da silagem que diminuem sua aceitação como, por exemplo, fermentações indesejáveis.

Consumos de MS superiores a estes geralmente podem ser obtidos à medida em que se aumenta a proporção de concentrado na ração. Coelho (2002) observou ingestão de MS de 1,88\% PV e ingestão de FDN de 1,11\% PV ao fornecer silagem de Tifton 85 com $20 \%$ de concentrado.

Também Loures (2004) ao elevar a proporção de concentrado para 50\% obteve consumo de 2,03\% PV com silagem de Tanzânia, assim como outros autores (Ferreira et al., 1988; Martins et al., 1988; Pilar et al., 1994) apresentaram média de consumo de MS de 1,82 a 3,05\% do PV ao elevar o teor de concentrado a níveis superiores aos praticados no presente estudo.

Maiores consumos de MS (1,75 a 2,14\% PV) e de FDN (1,47\% PV) foram obtidos por Manzano (2002) e Chudy et al. (2001) com animais pastejando capins do gênero Panicum. Com animais em pastejo, desde que haja elevada disponibilidade de forragem fresca ocorrem maiores ingestões, por não apresentarem produtos resultantes de fermentação como nas forragens conservadas.

Além disso, o pastejo seletivo proporciona ao animal a possibilidade de escolha, o que faz aumentar a ingestão em relação a um animal ao qual é oferecida quantidade de alimento limitada. Segundo Clavero (2001), baixos valores de consumo para silagens têm sido atribuídos aos elevados teores de umidade e de ácido butírico e baixa digestibilidade da fibra.

Apesar do emurchecimento ser citado como um procedimento que eleva o consumo de silagens (Teller et al., 1993; Loures, 2004) por diminuir a umidade, a presença de ácidos da fermentação, etanol e compostos nitrogenados solúveis como amônia (Allen, 2000; Wright et al., 2000), o benefício dessa prática não foi observado no presente trabalho. 
Tabela 8. Valores para ingestão de MS e FDN, taxas de passagem de sólidos e líquidos e tempo médio de retenção (TMR) em bovinos recebendo rações à base de silagens de capim Tanzânia

\begin{tabular}{|c|c|c|c|c|c|c|c|c|c|}
\hline \multirow[b]{2}{*}{ Variáveis } & \multirow[b]{2}{*}{ T1 } & \multirow[b]{2}{*}{ T2 } & \multirow[b]{2}{*}{ T3 } & \multicolumn{2}{|c|}{ Tratamentos ${ }^{1,3}$} & \multirow[b]{2}{*}{ T6 } & \multirow[b]{2}{*}{$\mathrm{T} 7$} & \multirow[b]{2}{*}{ Média } & \multirow[b]{2}{*}{$\mathrm{CV}^{2}$} \\
\hline & & & & T4 & T5 & & & & \\
\hline \multicolumn{10}{|l|}{ Ingestão de MS } \\
\hline kg MS.dia ${ }^{-1}$ & $4,2^{\mathrm{a}}$ & $4,8^{\mathrm{a}}$ & $4,5^{\mathrm{a}}$ & $4,0^{\mathrm{a}}$ & $4,7^{\mathrm{a}}$ & $4,4^{\mathrm{a}}$ & $5,0^{a}$ & 4,5 & 16,1 \\
\hline kg MS.100 kg peso-1 & $1,0^{\mathrm{a}}$ & $1,2^{\mathrm{a}}$ & $1,1^{\mathrm{a}}$ & $1,0^{\mathrm{a}}$ & $1,1^{\mathrm{a}}$ & $1,1^{\mathrm{a}}$ & $1,2^{\mathrm{a}}$ & 1,1 & 17,7 \\
\hline \multicolumn{10}{|l|}{ Ingestão de FDN } \\
\hline kg FDN.dia ${ }^{-1}$ & $2,7^{\mathrm{ab}}$ & $3,1^{\mathrm{a}}$ & $2,9^{\mathrm{ab}}$ & $2,6^{a b}$ & $3,0^{\mathrm{a}}$ & $2,8^{\mathrm{ab}}$ & $2,0^{b}$ & 2,7 & 18,6 \\
\hline kg FDN.100 kg peso ${ }^{-1}$ & $0,7^{\mathrm{ab}}$ & $0,8^{a}$ & $0,7^{\mathrm{ab}}$ & $0,7^{\mathrm{ab}}$ & $0,7^{\mathrm{a}}$ & $0,7^{\mathrm{ab}}$ & $0,5^{\mathrm{b}}$ & 0,7 & 18,9 \\
\hline \multicolumn{10}{|l|}{ Taxa de Passagem } \\
\hline Sólidos (\%.hora ${ }^{-1}$ ) & $2,0^{\mathrm{a}}$ & $2,3^{\mathrm{a}}$ & $2,3^{\mathrm{a}}$ & $2,8^{\mathrm{a}}$ & $2,2^{\mathrm{a}}$ & $2,2^{\mathrm{a}}$ & $2,6^{\mathrm{a}}$ & 2,4 & 29,8 \\
\hline Líquidos (\%.hora ${ }^{-1}$ ) & $3,0^{\mathrm{a}}$ & $3,0^{\mathrm{a}}$ & $2,8^{\mathrm{a}}$ & $3,3^{a}$ & $3,4^{\mathrm{a}}$ & $3,3^{\mathrm{a}}$ & $3,4^{\mathrm{a}}$ & 3,2 & 17,7 \\
\hline TMR (horas) & $50,0^{a}$ & $43,1^{a}$ & $43,5^{a}$ & $35,7^{\mathrm{a}}$ & $44,6^{a}$ & $45,7^{\mathrm{a}}$ & $38,5^{a}$ & 43,0 & 30,3 \\
\hline
\end{tabular}

${ }^{1}$ T1 - Umidade original, partícula menor, sem inoculante bacteriano; T2 - Umidade original, partícula menor, com inoculante bacteriano;T3 Emurchecido, partícula maior, com inoculante bacteriano; T4 - Emurchecido, partícula maior, sem inoculante bacteriano; T5 - Umidade original, partícula maior, com inoculante bacteriano; T6 - Umidade original, partícula maior, sem inoculante bacteriano; T7 - Umidade original, partícula maior, sem inoculante bacteriano, com milheto.

${ }^{2}$ coeficiente de variação (\%).

${ }^{3}$ Médias na mesma linha, seguidas por letras diferentes, diferem entre si pelo teste de Tukey $(P<0,05)$. 
Dawson et al. (1999) já haviam afirmado que, apesar do emurchecimento estar sendo preconizado como meio de melhorar a qualidade da fermentação da silagem e diminuir a produção de efluente, os efeitos na ingestão e desempenho animal têm sido muito variáveis, ocorrendo o desaparecimento destes efeitos à medida em que a proporção de concentrado é elevada na ração (Marsh, 1979). Como nesse trabalho a quantidade de concentrado utilizada foi mínima, não foi essa a causa da falta de efeito do emurchecimento sobre a ingestão.

Elevações na ingestão e no ganho de peso têm sido atribuídas também ao uso de inoculante bacteriano (Charmley et al., 1996; Haigh, 1998; Winters et al., 2001), possivelmente devido à melhor qualidade da fermentação das silagens, sugerindo que o aditivo bacteriano limitaria a degradação protéica, inicialmente diminuindo o $\mathrm{pH}$ e inibindo a atividade de enzimas e, em seguida suprimindo o crescimento de bactérias que degradam proteína. Com isso haveria menor produção de amônia e ácidos indesejáveis, como o butírico e o propiônico.

No entanto, no presente trabalho o $\mathrm{pH}$ não foi afetado $(P>0,05)$ pelo uso de inoculante e apesar das silagens inoculadas tenderem a apresentar maiores ingestões de MS não diferiram significativamente dos demais tratamentos $(P>0,05)$. Rodrigues et al. (2001) também observaram que o uso de inoculante bacteriano não melhorou a ingestão de silagem de capim Elefante por ovinos.

Vale ressaltar que a compactação inadequada realizada nos silos poder ter anulado o efeito benéfico que o emurchecimento e a presença do inoculante teriam sobre a ingestão, uma vez que silagem mal compactada não cria meio favorável para a fermentação anaeróbica.

Um fato relatado na literatura, que contribui para a baixa ingestão de forragens tropicais, é seu reduzido teor protéico (Milford \& Minson, 1966; Paterson et al., 1994; NRC, 1996). Rações com elevada proporção de fibra e pouco $\mathrm{N}$ geralmente respondem bem à suplementação protéica ou com NNP, 
elevando a ingestão substancialmente, sendo esta resposta maior se o teor de PB da ração estiver abaixo de 6 a 8\% (Milford \& Minson, 1966).

Como pode ser observado pelos dados da Tabela 7, embora os teores de PB das rações estivessem acima de $7,70 \%$, em média 19,24\% do $N$ total da silagem estava na forma indisponível como N-FDA. Isso pode ter gerado deficiência de N ruminal, prejudicando a degradação ruminal da fibra, produção de massa microbiana, reduzindo a taxa de passagem, causando enchimento ruminal e diminuição na ingestão (Brown \& Pitman, 1991; Allen, 2000). Conseqüentemente, causaria deficiência de proteína intestinal, prejudicando o perfil de aminoácidos absorvidos. Embora exista a possibilidade de parte da proteína que tenha sido transformada em amônia, presente na silagem, poder vir a ser utilizada no rúmen, compensando ou não a PB indisponível como NFDA.

\subsubsection{Taxa de passagem e tempo médio de retenção}

O requisito básico para a forragem passar do rúmen para sítios de digestão posteriores é sua redução a partículas menores, facilitando a digestão e acelerando o fluxo pelo trato digestivo.

Segundo Wilson et al. (1989) a mastigação na ingestão é fundamental para reduzir comprimento de partícula, porém esta mastigação não altera consideravelmente a espessura da partícula, tarefa esta devida à degradação microbiana ruminal. Porém, estes mesmos autores indicaram que há outros fatores controlando taxa de passagem e digestão que não somente a redução de tamanho de partícula e degradação ruminal.

Para Welch (1986) a ruminação é a atividade mais importante para diminuir tamanho de partícula de material grosseiro e garantir que saia do rúmen. No entanto como a maioria das partículas do rúmen são pequenas o suficiente para passar pelo orifício, algum outro mecanismo evitaria sua saída, funcionando como um filtro ou uma malha que retém estas partículas. 
$\mathrm{Na}$ Tabela 8 podem ser observados os valores para as taxas de passagem de sólidos e líquidos, que foram em média 2,35 e 3,17\%, respectivamente, não havendo efeito $(P>0,05)$ de tratamentos sobre estes parâmetros.

O tempo médio de retenção (TMR), ou seja, o tempo em que o alimento permaneceu no rúmen, foi calculado através da fórmula TR $=1 \mathrm{k}^{-1}$, sendo $\mathrm{k} a$ taxa de passagem de sólidos (Ellis et al., 1994). O TMR médio foi de 43 horas, não havendo diferença entre tratamentos $(P>0,05)$, sendo este dado inferior às 45 horas obtidas por Loures (2004).

Loures (2004) observou taxa de passagem de 2,23\%.h $\mathrm{h}^{-1}$ para sólidos e de $4,83 \% \mathrm{~h}^{-1}$ para líquidos com rações à base de silagem de capim Tanzânia e $50 \%$ de concentrado. O valor observado por Coelho (2002) para taxa de passagem de sólidos foi de $2,63 \% \cdot h^{-1}$ e líquido de $4,43 \% \cdot h^{-1}$, valores estes acima dos obtidos no presente trabalho, podendo ser justificados pela maior proporção de concentrado na rações utilizadas por estes autores.

Mas, se a taxa de passagem de sólidos foi semelhante e o TMR aqui obtido foi inferior ao de Loures (2004), era de se esperar que a ingestão fosse maior, mas isso não ocorreu. Com base nesses parâmetros, nota-se que os animais neste experimento consumiram abaixo do potencial, devido a algum fator limitante que não o TMR e às taxas de passagem, levando à suposição que o fator limitante pode ter sido a baixa aceitação.

Tanto a mastigação como a degradação microbiana contribuem para a desintegração do alimento e determinam a extensão de tempo que os alimentos ficam retidos no rúmen. A ingestão voluntária de matéria orgânica é inversamente relacionada com o tempo de retenção da matéria orgânica no rúmen (Thornton \& Minson, 1973).

De certo modo esta retenção ruminal até é necessária para a manutenção do ambiente favorável ao desenvolvimento microbiano, no que concorda Wilson et al. (1989), que menciona que fatores isolados, como 
tamanho de partícula, tempo médio de retenção ou taxa de passagem, não determinam o enchimento ruminal exclusivamente.

\subsubsection{Comportamento ingestivo do animal}

O tempo médio que os animais dedicaram às atividades de ingestão de alimento (293 minutos.dia ${ }^{-1}$ ), ingestão de água (13), ruminação (432) e ócio (702) não foi influenciado pelos tratamentos $(P>0,05)$, assim como para 0 tempo de ingestão por kg de MS (68). As médias são apresentadas na Tabela 9.

Em pastejo, devido à necessidade da busca pelo alimento, pode ser que o tempo de ingestão seja maior que com animais confinados, com isso restando menos tempo para ruminação, fato este observado por Manzano (2002) que observou tempos médios de pastejo, ruminação e em ócio de 413 , 364 e 664 minutos.dia $^{-1}$, respectivamente, sendo seu tempo de ingestão maior, embora o tempo de ruminação tenha sido menor em comparação ao presente experimento.

Os tempos gastos com as atividades de mastigação total (725 minutos. dia ${ }^{-1}$ ) ou mastigação por kg de MS (170) ou por kg de FDN (280) também não diferiram $(P>0,05)$ entre os tratamentos (Tabela 9$)$, havendo tendência $(P=0,07)$ do $T 7$ apresentar menor tempo de mastigação por kg de MS.

Houve efeito de tratamento para as variáveis de tempo gasto na ingestão de FDN $(P<0,05)$ e tempo gasto na ruminação de $M S(P<0,05)$, mas somente para o T7. No caso da ingestão de FDN o que ocorreu foi que o tempo total gasto na ingestão de alimentos não diferiu entre os tratamentos conforme mencionado anteriormente, mas como este tratamento apresentou menor concentração de FDN a divisão do tempo pela concentração gerou média superior. 
Tabela 9. Variáveis do comportamento ingestivo em bovinos que receberam rações contendo silagens de capim Tanzânia

\begin{tabular}{|c|c|c|c|c|c|c|c|c|c|c|}
\hline \multirow[b]{2}{*}{ Variáveis } & \multicolumn{10}{|c|}{ Tratamentos $^{1,3}$} \\
\hline & & $\mathrm{T} 1$ & T2 & T3 & T4 & T5 & T6 & $\mathrm{T7}$ & Média & $\mathrm{CV}^{2}$ \\
\hline \multirow[t]{3}{*}{ Ingestão } & minutos.dia $^{-1}$ & $293^{a}$ & $300^{a}$ & $294^{\mathrm{a}}$ & $317^{a}$ & $298^{a}$ & $268^{a}$ & $284^{\mathrm{a}}$ & 293 & 13,3 \\
\hline & minutos. $\mathrm{kg} \mathrm{MS}^{-1}$ & $70^{\mathrm{a}}$ & $63^{\mathrm{a}}$ & $69^{a}$ & $80^{a}$ & $68^{a}$ & $65^{a}$ & $60^{a}$ & 68 & 19,2 \\
\hline & minutos.kg FDN ${ }^{-1}$ & $109^{a}$ & $96^{\mathrm{a}}$ & $106^{\mathrm{a}}$ & $127^{\mathrm{a}}$ & $104^{\mathrm{a}}$ & $101^{\mathrm{a}}$ & $142^{b}$ & 112 & 20,9 \\
\hline \multirow[t]{3}{*}{ Ruminação } & minutos.dia ${ }^{-1}$ & $441^{a}$ & $438^{a}$ & $438^{a}$ & $432^{\mathrm{a}}$ & $448^{a}$ & $458^{a}$ & $366^{a}$ & 432 & 15,9 \\
\hline & minutos. $\mathrm{kg} \mathrm{MS}^{-1}$ & $117^{\mathrm{a}}$ & $96^{a}$ & $104^{\mathrm{a}}$ & $106^{a}$ & $103^{a}$ & $111^{\mathrm{a}}$ & $78^{\mathrm{b}}$ & 102 & 20,9 \\
\hline & minutos.kg FDN ${ }^{-1}$ & $183^{\mathrm{a}}$ & $146^{\mathrm{a}}$ & $163^{a}$ & $165^{\mathrm{a}}$ & $158^{\mathrm{a}}$ & $175^{\mathrm{a}}$ & $186^{b}$ & 168 & 23,1 \\
\hline \multirow[t]{3}{*}{ Mastigação 4} & minutos.dia ${ }^{-1}$ & $734^{a}$ & $737^{\mathrm{a}}$ & $732^{\mathrm{a}}$ & $749^{a}$ & $746^{\mathrm{a}}$ & $726^{a}$ & $651^{\mathrm{a}}$ & 725 & 12,0 \\
\hline & minutos. $\mathrm{kg} \mathrm{MS}^{-1}$ & $188^{\mathrm{a}}$ & $159^{\mathrm{a}}$ & $174^{\mathrm{a}}$ & $186^{\mathrm{a}}$ & $171^{\mathrm{a}}$ & $176^{\mathrm{a}}$ & $137^{\mathrm{a}}$ & 170 & 17,7 \\
\hline & minutos.kg FDN ${ }^{-1}$ & $292^{\mathrm{a}}$ & $242^{a}$ & $269^{a}$ & $291^{a}$ & $262^{a}$ & $276^{a}$ & $328^{a}$ & 280 & 20,1 \\
\hline Ócio & minutos. $\mathrm{dia}^{-1}$ & $696^{\mathrm{a}}$ & $694^{\mathrm{a}}$ & $694^{\mathrm{a}}$ & $660^{\mathrm{a}}$ & $694^{a}$ & $707^{\mathrm{a}}$ & $770^{\mathrm{a}}$ & 702 & 11,2 \\
\hline Ingestão de água & minutos.dia ${ }^{-1}$ & $10^{\mathrm{a}}$ & $12^{\mathrm{a}}$ & $19^{a}$ & $12^{\mathrm{a}}$ & $12^{\mathrm{a}}$ & $15^{\mathrm{a}}$ & $14^{\mathrm{a}}$ & 13 & 58,0 \\
\hline
\end{tabular}

${ }^{1}$ T1 - Umidade original, partícula menor, sem inoculante bacteriano; T2 - Umidade original, partícula menor, com inoculante bacteriano;T3 Emurchecido, partícula maior, com inoculante bacteriano; T4 - Emurchecido, partícula maior, sem inoculante bacteriano; T5 - Umidade original, partícula maior, com inoculante bacteriano; T6 - Umidade original, partícula maior, sem inoculante bacteriano; T7 - Umidade original, partícula maior, sem inoculante bacteriano, com milheto.

${ }^{2}$ coeficiente de variação (\%).

${ }^{3}$ Médias na mesma linha, seguidas por letras diferentes, diferem entre si pelo teste de Tukey $(P<0,05)$.

${ }^{4}$ Tempo de mastigação = tempos de ingestão + ruminação. 
O tempo dedicado à ingestão de água apresentou elevado coeficiente de variação no presente experimento (58\%) pois, sendo uma atividade realizada com pouca freqüência pelo animal e em intervalos muito curtos, nem sempre coincidiu com o momento de observação. Também Loures (2004) e Coelho (2002) realizando o mesmo procedimento de avaliação do comportamento ingestivo depararam-se com elevados coeficientes de variação para esta variável, de 70 e 53\%, respectivamente.

Holmes \& Mathews (2001) descreveram que o consumo em pastejo é um método relativamente lento, requerendo longos períodos por dia (9 a 10 horas), contrastando com períodos relativamente mais curtos para ingestão de rações à base de silagens e concentrados $\left(3,5\right.$ a $\left.4 \mathrm{~h}_{\text {.dia }}{ }^{-1}\right)$. Segundo estes autores as taxas médias de ingestão para pastagem é de 20-40 g MS.minuto-1, para feno/silagem é de 50-70 g MS.minuto ${ }^{-1}$ e para concentrados é de $250 \mathrm{~g}$ $\mathrm{MS} /$ minuto $^{-1}$ para os farelados e $350 \mathrm{~g} \mathrm{MS} /$ minuto $^{-1}$ para os peletizados.

No presente estudo, com consumo médio de $4,50 \mathrm{~kg}$ de $\mathrm{MS}_{\mathrm{dia}}{ }^{-1} \mathrm{e}$

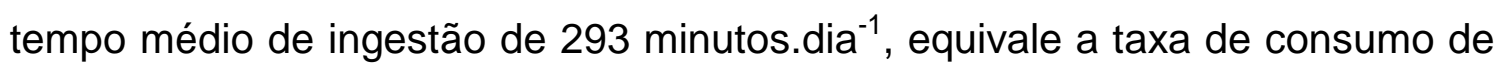
15,36 g MS.minuto de ingestão-1 ${ }^{-1}$ valor muito inferior aos 50-70 g citados por Holmes \& Mathews (2001) para silagens, revelando menor ingestão devido a algum fator limitante.

A proporção de concentrado na ração altera o tempo médio que os animais gastam executando cada atividade. Coelho (2002) usando silagens de capim Tifton 85 e $20 \%$ de concentrado obteve taxas de ingestão de MS de 21,28 g MS.minuto ${ }^{-1}$. Loures (2004) com 50\% de concentrado na ração elevou a taxa de ingestão para $41 \mathrm{~g} \mathrm{MS}$. minuto de ingestão ${ }^{-1}$, podendo se inferir que em rações contendo menor proporção de concentrado, como a utilizada neste trabalho, o animal pode gastar mais tempo ingerindo, mas sua ingestão total de MS é menor.

O tempo de ruminação relatado por Loures (2004) foi de 43

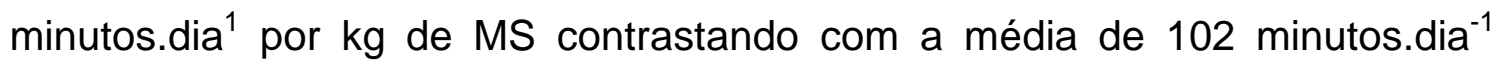
deste trabalho, mais uma vez indicando que rações com elevada proporção de 
fibra requerem maior tempo em ingestão e em ruminação (Teller et al., 1993; Paterson et al., 1994; Allen; 2000). A diferença na concentração de FDN na ração fornecida pelos referidos autores (52\%) e a utilizada neste experimento (66\%) pode ter sido responsável por este comportamento.

Para Patterson et al. (1994) forragens muito fibrosas e com partículas longas requerem maior tempo de mastigação, em torno de 70-100 minutos.kg $\mathrm{MS}^{-1}$, sendo 35-45 minutos. $\mathrm{kg} \mathrm{MS}^{-1}$ a quantidade de tempo mínima requerida em mastigação para efetiva ruminação e apropriada fermentação ruminal. Comparando com o tempo médio de mastigação de 137 minutos.kg MS ${ }^{-1}$ obtida neste trabalho, constata-se como esta ração, basicamente volumosa, demandou maior tempo de mastigação que rações com elevado teor de concentrado.

Harrison \& Blauwiekel (1994) afirmaram que quando o animal rumina mais que 9 horas por dia, elevando-se o teor de parede celular na ração resulta em diminuição na ingestão mais que aumento no tempo de ruminação, concordando com Van Bruchen et al. (1991) que afirmaram que a ingestão correlaciona-se negativamente com teor de FDN e positivamente com ruminação.

\subsubsection{Digestibilidade aparente no trato digestivo}

Na Tabela 10 são apresentado os dados referentes `a digestibilidade aparente no trato digestivo total dos bovinos de corte recebendo rações à base de silagem de capim. Não houve efeito $(P>0,05)$ de tratamentos sobre as digestibilidades da MS (61,40\%), MO (62,82\%), PB (43,93\%), FDN (60,34\%), FDA $(59,69 \%)$ e CEL $(66,73 \%)$.

No caso da HEMI a maior digestibilidade foi obtida no T3 $(71,16 \%)$ e a menor no $T 7(50,52 \%)$, que diferiram entre si $(P<0,05)$ mas não diferiram das demais $(P>0,05)$, que apresentaram valores intermediários. As demais frações 
fibrosas (FDN, FDA, CEL) também revelaram tendência $(P>0,05)$ em apresentar menor digestibilidade no T7 (Tabela 10).

Com silagens de capim Elefante têm-se obtido valores de digestibilidade de MS que variam entre 52,85\% (Silveira et al., 1980; Junqueira, 1995; Narciso Sobrinho et al., 1998b; Souza et al., 2001; Vilela et al., 2001;) e 64\% (Silveira et al., 1980; Junqueira, 1995; Narciso Sobrinho et al., 1998b; Souza et al., 2001; Vilela et al., 2001).

Para digestibilidade da $\mathrm{MO}$ os valores citados são compreendidos entre 52,52\% (Korndörfer, 1999; Chudy et al. 2001; Loures, 2002) e 71\% (Coelho, 2002), estando a média de $62,82 \%$ obtida neste trabalho, de acordo com dados encontrados de literatura. Teller et al. (1993) observaram que o emurchecimento reduziu a digestibilidade da MO no trato total, efeito este não observado no presente experimento.

Houve tendência de aumento nas digestibilidades da MS e da MO para o tratamento $T 7$ e apesar desse tratamento ter apresentado tendência $(P>0,05)$ de diminuição da digestibilidade para as frações fibrosas FDA, FDN e CEL, esse efeito foi significativo $(P<0,05)$ somente para a HEMI (Tabela 10). Isto ocorre pois carboidratos prontamente fermentáveis, provenientes dos ingredientes concentrados, reduzem a degradação microbiana da hemicelulose mais que da celulose, explicando o comportamento ocorrido (Dixon \& Stockdale, 1999) para as frações fibrosas.

Quanto à digestibilidade de FDN a média de 60,34\% está entre os $51,31 \%$ (Loures, 2004) e 71,00\% (Coelho, 2002) relatados para silagens de gramíneas. No caso da fração FDA também a média de 59,69\% está dentro do esperado, de 50,99\% (Loures, 2004) a 65, 00\% (Coelho, 2002).

Manzano (2002) obteve em pastejo de capim Tanzânia digestibilidades aparentes para a FDN de $66,13 \%$ e para a FDA de $67,95 \%$, maiores do que no presente trabalho, isso pode ser justificado pelo fato de que animal em pastejo realiza pastejo seletivo, desde que haja elevada disponibilidade, podendo ingerir material mais digestível. 
Tabela 10. Valores de digestibilidade aparente (\%) dos nutrientes no trato total, obtidos por coleta total de fezes, em bovinos alimentados com rações à base de silagem de capim Tanzânia

\begin{tabular}{|c|c|c|c|c|c|c|c|c|c|}
\hline \multirow[b]{2}{*}{ Digestibilidade $(\%)^{4}$} & \multicolumn{8}{|c|}{ Tratamentos $^{1,3}$} & \multirow[b]{2}{*}{$\mathrm{CV}^{2}$} \\
\hline & $\mathrm{T} 1$ & $\mathrm{~T} 2$ & T3 & T4 & T5 & T6 & $\mathrm{T} 7$ & Médias & \\
\hline MS & $60,3^{a}$ & $59,8^{a}$ & $61,8^{a}$ & $59,5^{a}$ & $61,3^{a}$ & $59,7^{a}$ & $67,4^{a}$ & 61,4 & 7,1 \\
\hline $\mathrm{MO}$ & $61,6^{a}$ & $61,4^{\mathrm{a}}$ & $63,4^{\mathrm{a}}$ & $60,7^{a}$ & $62,3^{\mathrm{a}}$ & $61,0^{\mathrm{a}}$ & $69,4^{a}$ & 62,8 & 6,7 \\
\hline PB & $42,2^{a}$ & $45,9^{a}$ & $46,3^{a}$ & $42,0^{a}$ & $42,3^{a}$ & $41,2^{a}$ & $47,6^{a}$ & 43,9 & 25,5 \\
\hline FDN & $61,9^{a}$ & $61,2^{a}$ & $63,3^{a}$ & $61,1^{a}$ & $62,1^{a}$ & $59,7^{a}$ & $53,2^{a}$ & 60,3 & 9,4 \\
\hline FDA & $63,0^{a}$ & $60,4^{a}$ & $59,6^{a}$ & $61,0^{a}$ & $61,9^{a}$ & $58,7^{a}$ & $53,3^{a}$ & 59,7 & 12,8 \\
\hline CEL & $70,2^{a}$ & $67,4^{a}$ & $66,0^{a}$ & $67,5^{a}$ & $68,5^{a}$ & $66,7^{\mathrm{a}}$ & $60,98^{a}$ & 66,7 & 10,0 \\
\hline HEMI & $59,7^{a b}$ & $63,4^{a b}$ & $71,2^{\mathrm{a}}$ & $63,0^{a b}$ & $63,6^{a b}$ & $63,5^{a b}$ & $50,5^{b}$ & 62,1 & 12,9 \\
\hline
\end{tabular}

ГT1 - Umidade original, partícula menor, sem inoculante bacteriano; T2 - Umidade original, partícula menor, com inoculante bacteriano;T3 Emurchecido, partícula maior, com inoculante bacteriano; T4 - Emurchecido, partícula maior, sem inoculante bacteriano; T5 - Umidade original, partícula maior, com inoculante bacteriano; T6 - Umidade original, partícula maior, sem inoculante bacteriano; T7 - Umidade original, partícula maior, sem inoculante bacteriano, com milheto.

${ }^{2}$ coeficiente de variação (\%).

${ }^{3}$ Médias na mesma linha, seguidas por letras diferentes, diferem entre si pelo teste de Tukey $(P<0,05)$.

${ }^{4} \mathrm{MS}=$ matéria seca; $\mathrm{MO}=$ matéria orgânica; PB = proteína bruta; FDN = fibra em detergente neutro; FDA = fibra em detergente ácido; $\mathrm{HEMI}=$ hemicelulose; $\mathrm{CEL}=$ celulose. 
No entanto, observando os dados de digestibilidade da Tabela 10 o fato que mais chama a atenção é a baixa digestibilidade da PB, com valores abaixo mesmo das frações fibrosas, exibindo média de 43,93\%. Uma possível explicação pode ser a elevada indigestibilidade da $\mathrm{PB}$, que neste trabalho apresentou média de $20,52 \%$ do $\mathrm{N}$ total da silagem na forma de $\mathrm{N}-\mathrm{FDA}$. Como mais de $86 \%$ da MS da ração foi composta pela silagem, isto pode ter contribuído para o baixo valor de digestibilidade da PB. Baixa digestibilidade da PB também foi observadas por Korndörfer (1999), com ovinos, que foi de $37 \%$ ao utilizar feno de Brachiaria decumbens.

Outro fator que pode contribuir para a redução na digestibilidade aparente da PB é a excreção de produtos metabólicos, sendo a proteína o principal deles. Secreções no trato digestivo assim como descamações contribuem para elevar a quantidade de produtos protéicos que, presentes nas fezes, fazem diminuir a digestibilidade da PB. A excreção de produtos metabólicos é diretamente proporcional à ingestão de MS, independente do tipo de forragem, estando a quantidade de produto metabólico excretado nas fezes entre 0,098 e 0,129 g.g MS ingerida ${ }^{-1}$ (Rymer, 2000).

Valores de digestibilidade da PB normalmente encontrados na literatura são superiores a este, variando entre 53 a 63\%, como observado por Manzano (2002) até 69\% (Coelho, 2002).

Chudy et al. (2001) estudando forragem fresca de Panicum maximum cv Gatton observaram baixos teores de PB (4,9 a 9,0\%) combinados com baixa digestibilidade desta PB (62\%), resultando em conteúdo de proteína digestível muito baixo (44 g. $\mathrm{kg}^{-1} \mathrm{MS}$ ). Mesmo sendo este valor de digestibilidade considerado baixo pelos autores, encontra-se acima do obtido no presente experimento.

O aumento da fração N-FDA durante o processo de ensilagem ocorre quando há elevação de temperatura no silo, ocorrendo a reação denominada de Maillard, na qual açúcares e aminoácidos são polimerizados elevando o teor de 
N-FDA da silagem (Rotz \& Muck, 1994) em adição aquele previamente existente na forragem.

Porém, no presente trabalho, parece que este processo não foi o único responsável pela elevação do teor de N-FDA, que passou de $16,54 \%$ do $\mathrm{N}$ total na forragem na ensilagem (Tabela 4) para 20,52\% na silagem (Tabela 6), o valor de N-FDA já apresentava-se elevado na forragem original.

Apesar do $\mathrm{N}$ indigestível ( $\mathrm{N}-\mathrm{FDA}$ ) presente em alfafa sem aquecimento ter coeficiente de digestibilidade igual a zero, segundo Broderick (1994) o NFDA produzido por aquecimento pode ter digestibilidade aparente de aproximadamente $40 \%$ o que sugere que o N-FDA da forragem pode ser compreendido entre fração completamente indigestível e fração parcialmente digestível. Assim, embora a reação de Maillard tenha digestibilidade baixa (40\%) o $\mathrm{N}$ indigestível presente antes do aquecimento é menos digestível ainda.

Waldo (1977) também havia sugerido que o aquecimento que ocorre, principalmente em silagens emurchecidas, diminui a solubilidade da proteína e sua digestibilidade, sendo baixa a proporção de proteína verdadeira que chegará ao intestino dos animais que consomem elevadas proporções de silagens de gramíneas (Heimbeck et al., 2003).

Balsalobre (2002) observou valor de N-FDA para capim Tanzânia de 9,92\%, como percentagem do N total, e Brown \& Pitman (1991) observaram em gramíneas tropicais (Paspalum e Hemarthria) teor de 7,85\%, valores estes bem inferiores aos $16,54 \% \mathrm{~N}$-FDA analisados na forragem deste experimento antes da ensilagem.

No presente experimento, como o teor de PB das rações já estava próximo do limite mínimo, com $8,78 \%$ de $\mathrm{PB}$ na ração total, o fato de aproximadamente $20 \%$ do $\mathrm{N}$ total da silagem estar na forma de $\mathrm{N}-\mathrm{FDA}$ indisponível, pode ter levado à deficiência de $\mathrm{N}$ que limitaria a degradação ruminal, reduzindo a taxa de passagem e conseqüentemente a ingestão de MS. 


\subsubsection{Parâmetros ruminais}

\subsubsection{1 pH}

$\mathrm{O} \mathrm{pH}$ ruminal é muito responsivo ao comportamento ingestivo realizado pelo animal, principalmente pelo padrão de mastigação, havendo elevações durante os turnos de ingestão e ruminação e queda no seu valor algumas horas após as refeições.

$\mathrm{O}$ valor de $\mathrm{pH}$ ruminal pode ser mantido através do aumento no poder de neutralização ou diminuindo a produção de ácidos (Church, 1993; Allen, 1997). Maior queda no valor do $\mathrm{pH}$ após a refeição ocorre quanto maior o tamanho da refeição e menor o teor de FDN da ração, não exclusivamente pelo teor de FDN, mas pelo estímulo à ruminação e fluxo de saliva para o rúmen.

A saliva é um importante mecanismo para remoção do íon $\mathrm{H}^{+}$da solução ruminal, pois contém carbonato que, ligado ao $\mathrm{H}^{+}$forma água e $\mathrm{CO}_{2}$, removendo $\mathrm{o}^{+}$. Além de apresentar efeito tamponante devido à grande quantidade de sais de $\mathrm{Na}$ e K, que neutralizam ácidos liberados na fermentação (Allen, 1997; Dixon \& Stockdale, 1999).

Pela observação dos dados da Tabela 11, constatou-se diferença significativa nos valores de $\mathrm{pH}$ em função dos tratamentos adotados $(P<0,01)$, sendo o valor mais baixo $(6,46)$ observado no tratamento $T 7$, valores intermediários $(7,02)$ nos T2; T4; T5 e T6 e os maiores valores $(7,11)$ nos T1 e T3. Também houve efeito para hora do dia $(P<0,01)$ e para a interação entre hora do dia e tratamento $(P<0,01)$.

$\mathrm{O}$ menor valor de $\mathrm{pH}$ do tratamento $\mathrm{T} 7$ é atribuído à maior proporção de matéria orgânica digestível vinda do milheto nesta silagem, fornecendo mais substrato para a fermentação, contribuindo dessa forma para a queda mais acentuada no valor de $\mathrm{pH}$, além deste tratamento ter apresentado menor concentração de FDN na ração (Tabela 7) e menor tempo de ruminação por kg de MS (Tabela 9). 
Tabela 11. Médias para variáveis ruminais observadas em bovinos recebendo rações contendo silagens de capim Tanzânia

\begin{tabular}{|c|c|c|c|c|c|c|c|c|c|c|c|c|}
\hline \multirow[b]{2}{*}{ Variáveis } & \multicolumn{8}{|c|}{ Tratamentos $^{1,3}$} & \multicolumn{4}{|c|}{ Efeitos $(P<)^{4}$} \\
\hline & $\mathrm{T} 1$ & $\mathrm{~T} 2$ & T3 & $\mathrm{T} 4$ & T5 & T6 & $\mathrm{T} 7$ & Média & $\mathrm{CV}^{2}$ & 1 & 2 & 3 \\
\hline \multicolumn{13}{|l|}{ Concentração de } \\
\hline \multicolumn{13}{|l|}{ AGV (mM) } \\
\hline Ácido acético & $48,9^{d}$ & $51,7^{\mathrm{cd}}$ & $53,3^{\mathrm{cd}}$ & $59,8^{b}$ & $56,1^{b c}$ & $57,3^{\mathrm{bc}}$ & $69,3^{a}$ & 56,6 & 17,2 & ** & ** & 0,9 \\
\hline Ácido propiônico & $11,4^{\mathrm{c}}$ & $12,2^{b c}$ & $12,9^{a b}$ & $13,8^{a}$ & $12,5^{b}$ & $11,8^{\mathrm{bc}}$ & $13,6^{a}$ & 12,4 & 15,6 & $\star *$ & ** & 0,9 \\
\hline Ácido butírico & $5,9^{d}$ & $7,5^{b}$ & $6,2^{\mathrm{cd}}$ & $6,9^{b c}$ & $7,1^{b}$ & $7,6^{\mathrm{b}}$ & $12,8^{a}$ & 7,7 & 18,6 & $\star *$ & $\star *$ & 0,1 \\
\hline Ácido isobutírico & $1,3^{c}$ & $1,0^{d}$ & $0,7^{\mathrm{e}}$ & $0,7^{\mathrm{e}}$ & $1,4^{\mathrm{b}}$ & $1,0^{d}$ & $1,8^{a}$ & 1,2 & 23,3 & ** & ** & * \\
\hline Ácido valérico & $0,5^{c}$ & $0,4^{\mathrm{bc}}$ & $0,4^{\mathrm{bc}}$ & $0,4^{c}$ & $0,4^{\mathrm{bc}}$ & $0,5^{b}$ & $1,5^{\mathrm{a}}$ & 0,6 & 31,3 & $\star *$ & ** & $* *$ \\
\hline Àcido isovalérico & $0,8^{b}$ & $0,8^{b}$ & $0,6^{c}$ & $0,6^{c}$ & $0,9^{b}$ & $0,9^{b}$ & $2,5^{\mathrm{a}}$ & 1,1 & 31,1 & ** & $\star *$ & ** \\
\hline Relação C2:C3 & $4,3^{b c}$ & $4,3^{c}$ & $4,1^{c}$ & $4,3^{b c}$ & $4,5^{b}$ & $5,0^{a}$ & $5,1^{a}$ & 4,6 & 11,2 & ** & 0,70 & 0,9 \\
\hline AGV Total & $68,6^{d}$ & $73,7^{\mathrm{cd}}$ & $74,1^{\mathrm{cd}}$ & $82,1^{b}$ & $78,4^{b c}$ & $79,2^{b c}$ & $101,5^{a}$ & 79,6 & 15,7 & ** & $* *$ & 0,6 \\
\hline $\mathrm{pH}$ & $7,1^{\mathrm{a}}$ & $7,0^{b}$ & $7,1^{\mathrm{a}}$ & $7,0^{\mathrm{b}}$ & $7,0^{\mathrm{ab}}$ & $7,0^{\mathrm{ab}}$ & $6,5^{c}$ & 6,9 & 2,7 & ** & $\star *$ & $\star \star$ \\
\hline $\mathrm{N}-\mathrm{NH}_{3}\left(\mathrm{mg} \cdot \mathrm{dL}^{-1}\right)$ & $4,5^{b}$ & $6,2^{b}$ & $5,9^{b}$ & $3,7^{b}$ & $5,3^{b}$ & $5,4^{b}$ & $10,1^{a}$ & 5,9 & 69,9 & $\star *$ & $\star \star$ & 0,5 \\
\hline
\end{tabular}

${ }^{1}$ T1 - Umidade original, partícula menor, sem inoculante bacteriano; T2 - Umidade original, partícula menor, com inoculante bacteriano;T3 Emurchecido, partícula maior, com inoculante bacteriano; T4 - Emurchecido, partícula maior, sem inoculante bacteriano; T5 - Umidade original, partícula maior, com inoculante bacteriano; T6 - Umidade original, partícula maior, sem inoculante bacteriano; T7 - Umidade original, partícula maior, sem inoculante bacteriano, com milheto; ${ }^{2}$ coeficiente de variação (\%); ${ }^{3}$ Médias na mesma linha seguidas por letras diferentes diferem entre si pelo teste de Tukey $(P<0,05) ;{ }^{4}$ Efeitos: $1=$ tratamento; $2=$ hora do dia; $3=$ interação tratamento $\times$ hora do dia; ** $\mathrm{P}<0,01 ;{ }^{*} \mathrm{P}<0,05 ; \quad \mathrm{P}<0,10$. 
Os valores de $\mathrm{pH}$ apresentados na Tabela 11 encontram-se acima do valor médio de pH de 6,37 obtido por Loures (2004), pois além da proporção de concentrado utilizada pelo referido autor ter sido maior (50\%), o tempo de ruminação da MS (43 minutos. $\mathrm{kg} \mathrm{MS}^{-1}$ ) e de FDN (82 minutos. $\mathrm{kg} \mathrm{MS}^{-1}$ ) obtidos por Loures (2004) foram inferiores a estes. Portanto, o valor de pH de Loures (2004) aproxima-se mais do tratamento T7 do presente experimento, tratamento este que também continha mais concentrado.

Coelho (2002) utilizando a relação volumoso:concentrado de 80:20, observou média de $\mathrm{pH}$ de 6,76 , concordando com o valor de $\mathrm{pH}$ médio $(6,93)$ obtido neste estudo.

As diferenças ocorridas nos valores de $\mathrm{pH}$ nos demais tratamentos não podem ser atribuídas ao comportamento ingestivo, pois embora o tempo gasto na mastigação (minutos.kg FDN ${ }^{-1}$ ou $\mathrm{MS}^{-1}$ ) possa ser usado como um índice de avaliação da forragem (Allen, 1997) e, indiretamente, altere o pH ruminal, pelos dados da Tabela 9 pode-se constatar que não houve diferenças no padrão ingestivo que explicasse esta variação no valor de $\mathrm{pH}$ entre tratamentos.

\subsubsection{Evolução temporal da concentração do pH ruminal}

As variações que ocorreram nos valores de $\mathrm{pH}$ no período de 24 horas estão apresentadas na Figura 1, lembrando que os animais foram alimentados duas vezes ao dia, às 08 e às 18 horas. Os horários apresentados na Figura 1 correspondem às horas do dia em que foram realizadas as coletas de fluido ruminal.

Na Tabela 12 é apresentada a evolução nos valores de pH durante o dia, seguindo um padrão normal no qual os maiores valores foram observados por volta das 10 horas, aproximadamente duas horas após a refeição principal (08 horas), com valor médio de 7,20.

Durante a mastigação há secreção de saliva que, agindo como tamponante, contribui para elevação do pH ruminal, enquanto a fermentação do 


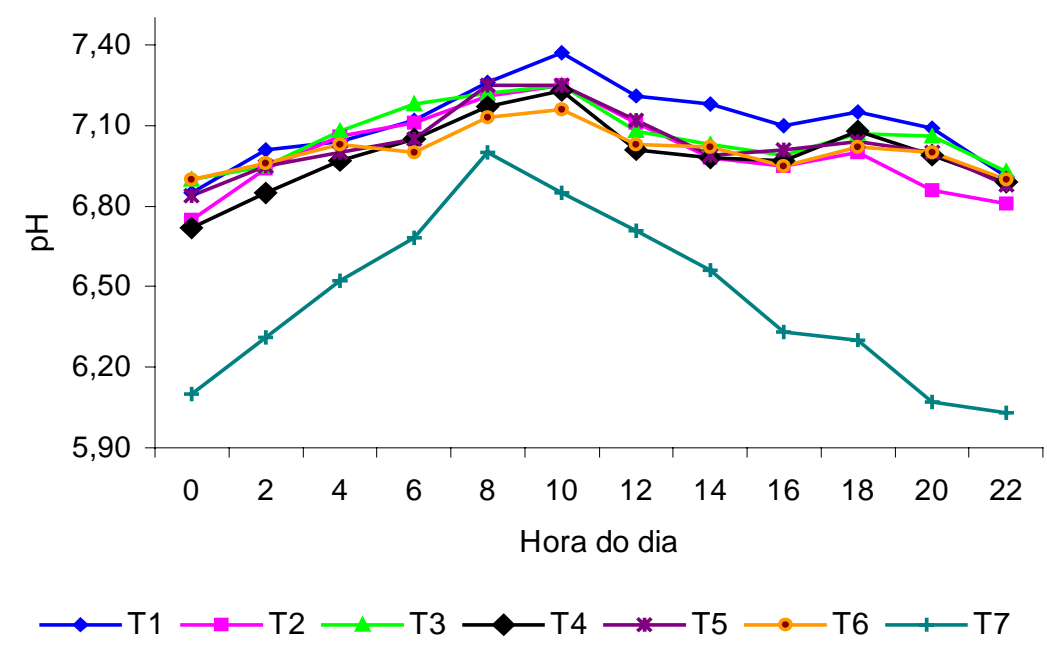

Figura 1 - Efeito das rações experimentais sobre a evolução temporal do pH no fluido ruminal

alimento ingerido ainda não iniciou sua contribuição com ácidos para queda no $\mathrm{pH}$, fato este que se iniciará por volta das 12:00 horas e se estenderá até aproximadamente às 16 horas.

Flutuações no $\mathrm{pH}$ ruminal refletem trocas entre as quantidades de ácidos que se acumulam no rúmen e a quantidade de saliva produzida. Church (1993) descreveu este comportamento, citando que o valor mais baixo de $\mathrm{pH}$ ocorre de 2 a 6 horas após a ingestão de alimento, e antes da ingestão os valores de $\mathrm{pH}$ variam de 6,25 a 7,30.

Com a segunda refeição (18:00 horas) ocorreu novo pico de pH, porém este foi menor que o da refeição matutina, devido à ingestão de menor proporção diária da ração, seguida por nova queda do valor do pH após às 20 horas. Por volta das 00 horas o $\mathrm{pH}$ atingiu seus menores valores $(6,73)$. Estas médias indicam que variações impostas pelos tratamentos não foram suficientemente expressivas a ponto de determinar redução significativa no $\mathrm{pH}$ ruminal, o que já era esperado devido elevada à participação de volumoso na ração, mantendo valores de $\mathrm{pH}$ acima de 6,73. 
Coelho (2002) e Loures (2004) observaram o mesmo comportamento quanto aos picos de $\mathrm{pH}$, sendo o maior deles observado após a refeição matutina e o menor após segunda refeição. Os autores relataram seus menores valores de $\mathrm{pH}$ como sendo 6,58 e 5,92 e maiores valores como 6,90 e 6,89, respectivamente, estando estas médias abaixo dos valores de mínima $(6,73)$ e máxima $(7,20)$ obtidos no presente estudo.

No entanto exceção ocorreu com o tratamento T7 que apresentou valor máximo de $\mathrm{pH}$ às 08 horas $(7,00)$ e o valor mínimo às 22 horas $(6,00)$, comportamento esperado uma vez que o tratamento continha mais milheto na sua composição do que os demais. Mesmo assim seus valores de pH não estiveram abaixo de 6,00, o que seria crítico para digestão de fibra no rúmen (Allen, 1997).

Dixon \& Stockdale (1999) estabeleceram que o pH ótimo para digestão microbiana da fibra estaria em torno de 6,6-7,0, e que a digestão seria reduzida se o valor de $\mathrm{pH}$ fosse diminuído para 6,2 e eliminada quando o $\mathrm{pH}$ estivesse abaixo de 6,0 .

\subsubsection{3 Ácidos graxos voláteis (AGV)}

Pela análise dos dados da Tabela 11 observa-se que foi detectada diferença para a concentração média dos ácidos graxos voláteis individuais $(P<0,01)$, relação $C 2: C 3(P<0,01)$ e AGV totais $(P<0,01)$ em função da variável tratamento, com o tratamento T7 apresentando a maior média de concentração para quase todos os ácidos individualmente e, conseqüentemente, para os AGV totais e relação $\mathrm{C} 2: \mathrm{C} 3$.

Também houve efeito de tempo para os AGV individuais $(P<0,01)$ e para os AGV totais $(P<0,01)$, mas não para a relação $C 2: C 3(P=0,70)$. Quanto à interação tratamento e tempo (Tabela 12) apenas houve efeito para os ácidos isobutírico $(P<0,05)$, valérico $(P<0,01)$ e isovalérico $(P<0,01)$. 
Tabela 12. Evolução temporal para as variáveis ruminais observadas em bovinos recebendo rações contendo silagens de capim Tanzânia

\begin{tabular}{|c|c|c|c|c|c|c|c|c|c|c|}
\hline \multirow[b]{2}{*}{ Hora } & \multirow[b]{2}{*}{ Acético } & \multirow[b]{2}{*}{ Propiônico } & \multicolumn{4}{|c|}{ Ácidos graxos voláteis (mM) } & \multirow[b]{2}{*}{$\begin{array}{c}\text { Relação } \\
\text { C2:C3 }\end{array}$} & \multirow[b]{2}{*}{$\begin{array}{l}A^{\prime} V^{1} \\
\text { Total }\end{array}$} & \multirow[b]{2}{*}{$\mathrm{pH}$} & \multirow[b]{2}{*}{$\begin{array}{l}\mathrm{N}-\mathrm{NH}_{3} \\
\mathrm{mg} \cdot \mathrm{dL}^{-1}\end{array}$} \\
\hline & & & Butírico & Isobutírico & Valérico & Isovalérico & & & & \\
\hline 00:00 & 64,6 & 14,6 & 8,6 & 1,1 & 0,6 & 0,9 & 4,4 & 90,4 & 6,7 & 3,6 \\
\hline 02:00 & 61,3 & 13,7 & 7,7 & 1,0 & 0,5 & 0,9 & 4,5 & 85,0 & 6,9 & 2,5 \\
\hline 04:00 & 57,1 & 12,9 & 6,9 & 0,9 & 0,4 & 0,8 & 4,4 & 79,0 & 7,0 & 3,6 \\
\hline 06:00 & 56,3 & 12,6 & 6,5 & 0,9 & 0,4 & 0,9 & 4,5 & 77,5 & 7,0 & 4,2 \\
\hline 08:00 & 50,5 & 11,3 & 6,1 & 0,9 & 0,4 & 1,0 & 4,5 & 70,1 & 7,2 & 5,5 \\
\hline 10:00 & 52,0 & 11,4 & 7,6 & 1,3 & 0,7 & 1,3 & 4,6 & 74,4 & 7,2 & 11,8 \\
\hline $12: 00$ & 53,0 & 11,7 & 8,1 & 1,4 & 0,7 & 1,3 & 4,5 & 76,3 & 7,1 & 9,6 \\
\hline $14: 00$ & 52,3 & 11,4 & 8,0 & 1,3 & 0,6 & 1,2 & 4,6 & 74,8 & 7,0 & 7,5 \\
\hline $16: 00$ & 53,6 & 11,7 & 7,8 & 1,2 & 0,6 & 1,0 & 4,6 & 75,8 & 6,9 & 5,1 \\
\hline 18:00 & 54,4 & 11,8 & 7,4 & 1,1 & 0,5 & 0,9 & 4,6 & 76,1 & 6,9 & 4,0 \\
\hline 20:00 & 63,7 & 14,0 & 9,3 & 1,4 & 0,8 & 1,2 & 4,5 & 90,3 & 6,9 & 7,7 \\
\hline $22: 00$ & 60,9 & 14,0 & 8,6 & 1,2 & 0,6 & 1,0 & 4,4 & 86,3 & 6,8 & 5,3 \\
\hline Médias & 56,6 & 12,4 & 7,7 & 1,2 & 0,6 & 1,1 & 4,6 & 79,6 & 6,9 & 5,9 \\
\hline
\end{tabular}

${ }^{1}$ Ácidos graxos voláteis totais, soma dos ácidos acético, propiônico, butírico, isobutírico, valérico e isovalérico. 
Os AGV são produtos finais da fermentação da matéria orgânica pelos microrganismos ruminais (Van Soest, 1994), sendo o principal deles o ácido acético. Os ácidos graxos são também ingeridos através da silagem, principalmente na forma de ácido lático, sendo rapidamente metabolizado no rúmen a ácidos acético (61\%), propiônico (34\%) e butírico (5\%). A quantidade de ácidos produzidos na fermentação ruminal dependem da ingestão quantitativa de matéria orgânica e da sua degradação ruminal (Allen, 1997).

Em ordem de abundância os AGV no ambiente ruminal aparecem como acético, propiônico, butírico, isobutírico, valérico e isovalérico e o balanço entre produção e absorção no rúmen, ou passagem pelo orifício omasal, é essencial para o crescimento e manutenção dos microrganismos celulolíticos no rúmen (Van Soest, 1994).

Considerando-se apenas os ácidos de maior participação no padrão de fermentação ruminal observa-se (Tabela 11), através dos dados desse trabalho, que a proporção entre os ácidos acético (C2), propiônico (C3) e butírico (C4), em relação aos AGV totais, geram uma relação de 71:16:10, refletindo um padrão típico de animais alimentados com ração contendo maior proporção de volumoso na ração, fato também observado por Coelho (2002).

A elevada produção de AGV diminui o pH (Church, 1993), e como a taxa de produção e a concentração de ácidos variam diariamente como conseqüência do padrão de ingestão, o pH também varia.

O ácido acético tem maior produção quando o animal recebe rações com elevada proporção de volumoso, fazendo elevar o $\mathrm{pH}$ ruminal pela elevação do requerimento de ruminação e salivação. Isso foi comprovado nesse experimento, devido ao fato da ração fornecida ter sido predominantemente volumosa (Tabela11). No caso de rações com elevada proporção de concentrado há estímulo da produção de ácidos propiônico e butírico levando a queda no valor de $\mathrm{pH}$ ruminal pela deficiência de fibra nestas rações que estimulem a ruminação. 
Embora a degradação ruminal seja desejável para maximizar a produção de proteína microbiana e a ingestão de energia, o aumento dos ácidos da fermentação deve ser compensado ou pelo aumento do teor de FDN da ração ou pelo aumento da efetividade física da FDN, mantendo o pH através de estímulo da secreção salivar tamponante, via mastigação e ruminação (Allen, 1997).

Keady \& Mayne (2001) citaram que ao elevar o teor de amido na ração eleva-se a concentração de propionato mas diminui a de acetato, embora pela observação dos dados deste trabalho nota-se tendência de elevação da concentração de ácido propiônico no T7 em relação aos demais tratamentos, sem que houvesse redução para o ácido acético.

Church (1993) já havia mencionado que ocorre maior concentração de ácido acético com silagens, fenos e pastos maduros, materiais que necessitam maior tempo de mastigação.

No entanto, o valor obtido de $79,64 \mathrm{mM}$ para AGV totais (Tabela 11) encontra-se abaixo da média de 140 mM de Coelho (2002) e dos 110 mM de Loures (2004), pelo fato da ração do presente experimento conter menor proporção de ingredientes concentrados que aquela utilizada pelos referidos autores.

\subsubsection{Evolução temporal da concentração de ácidos graxos}

Conforme pode ser observado na Tabela 12, as concentrações de ácidos acético e propiônico revelaram picos entre as 20 e as 02 horas. Os demais ácidos (butírico, isobutírico, valérico, isovalérico) apresentaram padrão mais uniforme na concentração durante o período de 24 horas, com picos bem definidos por volta das 12 e das 20 horas, horários estes de 2 a 4 horas após as refeições, refletindo a produção de ácidos pela fermentação a partir do alimento ingerido. 
Também pode ser observado que o tratamento T7 manteve, com exceção para o ácido propiônico, padrão mais elevado na concentração de ácidos que nos demais tratamentos, devido à contribuição de maior fração degradável e fermentável proveniente do milheto.

Embora tenham ocorrido algumas variações individuais para o C2 e o C3, a relação C2:C3 manteve-se relativamente uniforme durante o dia.

Após a refeição, aumentam-se as concentrações molares de AGV, ocorrendo picos a aproximadamente 4 horas pós-refeição e seguido-se lenta recuperação ao limiar normal (Van Soest, 1994). Apesar da concentração ruminal de AGV ser relacionada negativamente com o pH esta relação não é tão forte devido à variação no tamponamento e à neutralização que ocorre no rúmen.

Pelos dados da Tabela 12 nota-se que a concentração de AGV totais, apresentou pequeno pico por volta das 12 horas e outro pico mais definido por volta das 20 horas, refletindo comportamento apresentado pelos ácidos individuais.

Loures (2004) observou comportamento semelhante para os AGV totais com valores mínimo e máximo de 86 e $121 \mathrm{mM}$, pouco superiores aos obtidos no presente experimento (70,10 e 90,39 mM). Também Coelho (2002) observou valores de AGV totais mínimo (136 mM) e máximo (145 mM) superiores ao deste trabalho e às médias verificadas por Loures (2004).

Segundo Church (1993) e Allen (1997) há diferentes taxas de absorção para diferentes AGV, sendo o acético, o propiônico e o butírico absorvidos a taxas similares em pH neutro, mas havendo queda no $\mathrm{pH}$, os ácidos propiônico e butírico têm sua absorção elevada. Da absorção de AGV, $76 \%$ ocorre no rúmen, $19 \%$ no omaso e abomaso e $5 \%$ no intestino delgado.

Pode-se dizer que há sensibilidade de receptores epiteliais ao butirato, e em menor freqüência para propionato, sendo estimulados em $\mathrm{pH}$ inferior, com maior taxa de absorção (Allen, 2000). Ou seja, há preferência por absorção de ácidos graxos de cadeias mais longas (butírico), no entanto estes são 
extensivamente metabolizados na parede ruminal, de modo que ácidos de cadeias mais curtas, embora absorvidos em menor proporção aparecem em maior quantidade na circulação por não serem intensivamente metabolizados (acético e propiônico).

\subsubsection{Nitrogênio amoniacal $\left(\mathrm{N}-\mathrm{NH}_{3}\right)$}

Com base nos dados da Tabela 11, observa-se diferença na concentração de nitrogênio amoniacal em razão da variável tratamento $(P<0,01)$ e do tempo $(P<0,1)$, mas não para a interação entre tratamento e tempo $(P=0,49)$. Contudo, esta diferença na concentração de nitrogênio amoniacal somente ocorreu para o tratamento T7 $(P<0,05)$, com média de $10,13 \mathrm{mg} \cdot \mathrm{dL}^{-1}$, em relação aos demais tratamentos que não diferiram entre si $(P>0,05)$, apresentando média de $5,16 \mathrm{mg} \cdot \mathrm{dL}^{-1}$.

A maior concentração de nitrogênio amoniacal no T7 foi decorrente do maior teor protéico apresentado por este tratamento (Tabela 7) devido à maior participação de milheto. Excluindo este fato, evidencia-se que os demais fatores impostos como tratamentos não apresentaram efeito sobre esta variável.

O valor médio obtido neste estudo de $5,93 \mathrm{mg}_{\mathrm{dL}} \mathrm{dL}^{-1}$ situa-se entre os valores de $5,55 \mathrm{mg} \cdot \mathrm{dL}^{-1}$ obtidos de Loures (2004) e $6,32 \mathrm{mg} \cdot \mathrm{dL}^{-1}$ por Coelho (2002), ambos usando rações com maior proporção de concentrados e, conseqüentemente, maior teor protéico.

Segundo Church (1993) elevando-se a concentração de ácidos no rúmen diminui-se a absorção ruminal de amônia pelo efeito do baixo valor de $\mathrm{pH}$. Em pH 6,5, o transporte de amônia pelo epitélio ruminal aumenta com o gradiente de concentração. A absorção de amônia aumenta com a absorção de AGV, ou seja, à medida que AGV são removidos do rúmen por absorção ou taxa de passagem, o pH se eleva facilitando a absorção ruminal de amônia, entretanto a pH 4,5 a absorção de amônia é quase desprezível. 


\subsubsection{Evolução temporal da concentração de nitrogênio amoniacal}

Conforme Figura 2 e Tabela 12, fica evidente a ocorrência de picos de concentração de amônia ruminal às 10 e às 20 horas, ou seja, horários logo após o fornecimento das rações aos animais, evidenciando a rápida liberação de amônia à partir da uréia fornecida. Como $60 \%$ da ração total foi fornecida na primeira refeição do dia (8 horas), é compreensível que o maior pico de amônia ruminal tenha ocorrido pela manhã (Figura 1).

No caso do tratamento $\mathrm{T7}$, que além da uréia continha maior proporção de milheto, portanto maior teor protéico, apresentou nível mais elevado de amônia ruminal não somente no horário do pico mas, por longo período durante o dia, em relação aos demais tratamentos, por ser a proteína do milheto mais lentamente degradável que da uréia, responsável pela manutenção deste maior nível observado (Figura 2).

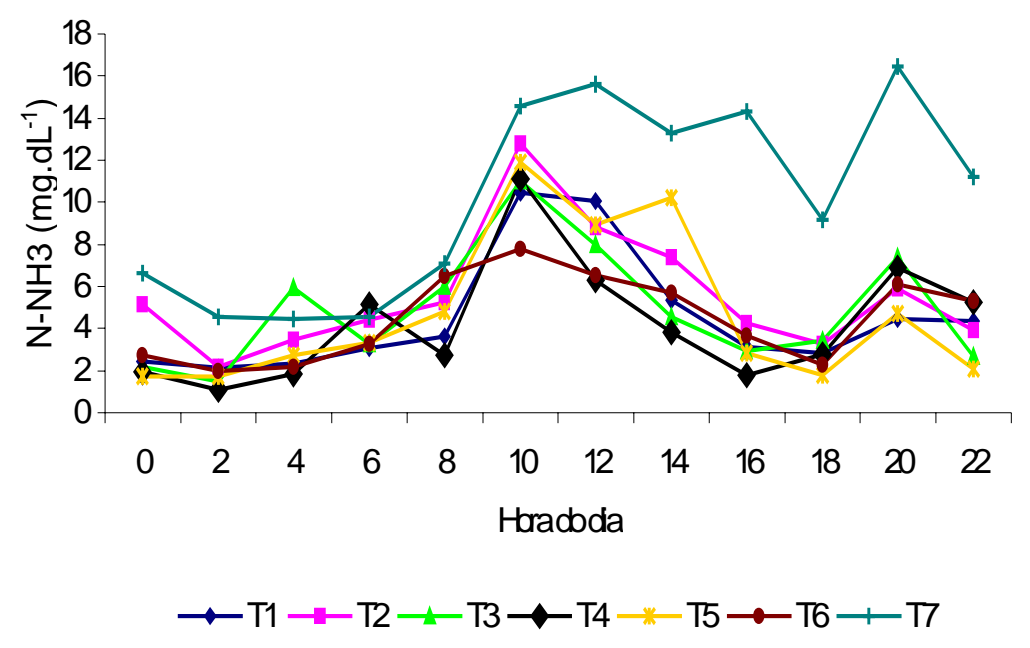

Figura 2 - Efeito das rações experimentais sobre a evolução temporal da concentração de nitrogênio amoniacal no fluido ruminal

Assim como os valores médios de nitrogênio amoniacal ruminal deste trabalho não diferiram daqueles observados por Loures (2004) e Coelho (2002), também os valores máximos e mínimos aqui obtidos $\left(11,77\right.$ e $\left.2,53 \mathrm{mg} \cdot \mathrm{dL}^{-1}\right)$ 
estiveram próximos aos observados por Loures (2004), que foram de 11,25 e 2,77 mg.dL ${ }^{-1}$ e Coelho (2002), que foram de $10,83 \mathrm{mg} \cdot \mathrm{dL}^{-1}$ e $3,68 \mathrm{mg} \cdot \mathrm{dL}^{-1}$, respectivamente.

\subsubsection{Degradabilidade in situ}

Para o cálculo da degradabilidade efetiva, foram consideradas as taxas de passagem $(\mathrm{kp})$ do alimento pelo rúmen determinadas neste experimento (Tabela 8) aplicadas ao modelo Fit curve desenvolvido pela Rowett Research Institute, Aberdeen, Escócia (http://www.mluri.sari.ac.uk/IFRU/fcurve.html).

\subsubsection{Degradabilidade in situ da matéria seca}

Os dados relacionados à degradabilidade ruminal da MS, FDN, FDA e HEMI são apresentados na Tabela 13.

Houve efeito $(P<0,05)$ de tratamento sobre a fração "a" da MS, com média geral de 15,49\%, porém somente o tratamento T7 diferiu dos demais apresentando valor elevado para esta fração "a" (42,93\%) devido à participação de milheto grão moído na sua composição. Se considerar somente a média da fração "a" em silagens exclusivas de capim (T1 ao T6) este valor foi de 10,04\%.

Esse valor está abaixo da média de 16,75\% obtida por Manzano (2002) e Balsalobre (2002) e aos $15,64 \%$ relatados por Simili et al. (2002), que utilizaram capim Tanzânia, contendo fração solúvel em maior quantidade que em silagens aqui utilizadas, nas quais já ocorreram perdas por fermentação.

O valor de fração "a" aqui obtido (10,04\%) em silagens sem adição de milheto (T1 ao T6) está muito acima dos 2,36\% mencionados por Loures (2004), pois esse autor adotou o procedimento de imergir os sacos de nailon em água morna antes da incubação, fato este que ocasionou a grande diferença, devido à remoção prévia da fração solúvel. 
Quanto à fração "b" não diferiu entre tratamentos $(P>0,05)$, com média de 46,13\%, apresentando-se abaixo da amplitude de 53 aos $66 \%$ encontrados na literatura para silagens de capim Tanzânia ou capim Tanzânia em pastejo (Pinto et al.; 1998; Balsalobre, 2002; Manzano, 2002; Mello et al.; 2002; Simili et al., 2002; Loures, 2004).

É compreensível que Loures (2004), Mello et al. (2002) e Simili et al. (2002) tenham obtido maior valor de "b" uma vez que o capim por eles utilizado apresentava menor idade de rebrota, seja na forma de silagem ou de forragem fresca, o que eleva a fração não solúvel mas potencialmente degradável.

A taxa de degradação média da MS foi de $4,81 \% \cdot h^{-1}$, não diferindo entre tratamentos $(P>0,05)$, porém compreendida dentro de valores observados em outros trabalhos, que variam entre 2,76 e $6,42 \% \cdot h^{-1}$ (Pinto et al., 1998; Manzano, 2002; Simili et al., 2002; Balsalobre; 2002; Mello et al., 2002). O trabalho realizado em condições semelhantes às deste estudo foi conduzido por Loures (2004) no qual foi observado valor de $4,54 \% \cdot h^{-1}$.

Houve efeito de tratamento $(P<0,05)$ para a degradabilidade efetiva da MS, porém somente para o T7 que apresentou maior média (65,53\%) em relação aos demais $(42,04 \%)$. Assim a média geral obtida neste trabalho (45,95\%) esteve próxima do valor médio de 45\% alcançado por Manzano (2002) e Loures (2004) mas abaixo dos 61,93\% obtidos por Balsalobre (2002), ficando o valor obtido nesse experimento abaixo da expectativa.

Também para degradabilidade potencial houve efeito de tratamento $(P<0,05)$ com o T7 apresentando a maior média $(78,07 \%)$ em relação aos demais $(58,53 \%)$. A média geral para os tratamentos $(61,42 \%)$ esteve compreendida dentro da amplitude que se observa em dados publicados, de 66 a 82\% (Simili et al., 2002; Loures, 2004; Manzano, 2002; Balsalobre, 2002).

Para o lag time, apesar de não ter havido diferença entre tratamentos, o T7 tendeu a apresentar menor valor (1,41 vs 2,92 horas). 
Tabela 13. Variáveis da degradabilidade in situ da matéria seca e FDN de silagens de capim Tanzânia

\begin{tabular}{|c|c|c|c|c|c|c|c|c|c|}
\hline \multirow[b]{2}{*}{ Variáveis } & \multicolumn{9}{|c|}{ Tratamentos $^{1,2}$} \\
\hline & T1 & $\mathrm{T} 2$ & T3 & $\mathrm{T} 4$ & T5 & T6 & $\mathrm{T} 7$ & Médias & $\mathrm{CV}$ \\
\hline & \multicolumn{9}{|c|}{ MS } \\
\hline a (\%) & $10,0^{b}$ & $11,4^{b}$ & $12,5^{b}$ & $8,3^{b}$ & $11,8^{b}$ & $6,0^{b}$ & $42,9^{a}$ & 15,9 & 35,4 \\
\hline b (\%) & $41,5^{a}$ & $46,4^{a}$ & $57,0^{a}$ & $53,3^{a}$ & $47,4^{a}$ & $52,3^{a}$ & $35,0^{a}$ & 46,1 & 27,9 \\
\hline$c\left(\% \cdot h^{-1}\right)$ & $4,9^{a}$ & $5,2^{a}$ & $3,9^{a}$ & $4,5^{\mathrm{a}}$ & $4,1^{\mathrm{a}}$ & $5,5^{\mathrm{a}}$ & $5,9^{a}$ & 4,8 & 27,8 \\
\hline Degradabilidade efetiva (\%) & $43,6^{b}$ & $43,4^{b}$ & $40,4^{b}$ & $40,1^{b}$ & $42,2^{b}$ & $42,5^{b}$ & $65,5^{a}$ & 45,9 & 6,6 \\
\hline Degradabilidade potencial (\%) & $57,6^{b}$ & $57,4^{b}$ & $58,8^{b}$ & $60,9^{b}$ & $58,9^{b}$ & $57,6^{b}$ & $78,1^{a}$ & 61,4 & 3,9 \\
\hline \multirow[t]{2}{*}{ Lag time (h) } & $3,7^{\mathrm{a}}$ & $3,2^{a}$ & $1,7^{\mathrm{a}}$ & $2,8^{a}$ & $2,6^{a}$ & $3,5^{\mathrm{a}}$ & $1,4^{\mathrm{a}}$ & 2,7 & 63,7 \\
\hline & \multicolumn{9}{|c|}{ FDN } \\
\hline$a(\%)$ & $1,6^{b}$ & $3,2^{a}$ & $4,1^{\mathrm{a}}$ & $2,3^{a}$ & $2,0^{b}$ & $2,3^{a}$ & $15,4^{a}$ & 4,1 & 174,1 \\
\hline b (\%) & $58,3^{b}$ & $56,5^{b}$ & $57,2^{b}$ & $62,9^{b}$ & $57,9^{b}$ & $62,0^{b}$ & $54,5^{b}$ & 58,8 & 13,1 \\
\hline $\mathrm{c}\left(\% \cdot \mathrm{h}^{-1}\right)$ & $4,5^{b}$ & $5,0^{b}$ & $4,1^{b}$ & $4,3^{b}$ & $4,3^{b}$ & $5,3^{b}$ & $4,4^{b}$ & 4,5 & 20,1 \\
\hline Degradabilidade efetiva (\%) & $39,1^{a}$ & $39,7^{a}$ & $35,8^{a}$ & $35,1^{a}$ & $38,6^{a}$ & $39,6^{a}$ & $40,7^{a}$ & 37,8 & 21,2 \\
\hline Degradabilidade potencial (\%) & $57,2^{a}$ & $57,3^{a}$ & $57,0^{a}$ & $60,1^{a}$ & $58,3^{a}$ & $57,2^{a}$ & $62,1^{a}$ & 58,1 & 8,3 \\
\hline Lag time (h) & $3,6^{a}$ & $3,7^{\mathrm{a}}$ & $1,8^{a}$ & $2,3^{a}$ & $3,4^{a}$ & $3,9^{a}$ & $2,2^{a}$ & 3,0 & 58,4 \\
\hline
\end{tabular}

${ }^{1}$ T1 - Umidade original, partícula menor, sem inoculante bacteriano; T2 - Umidade original, partícula menor, com inoculante bacteriano;T3 Emurchecido, partícula maior, com inoculante bacteriano; T4 - Emurchecido, partícula maior, sem inoculante bacteriano; T5 - Umidade original, partícula maior, com inoculante bacteriano; T6 - Umidade original, partícula maior, sem inoculante bacteriano; T7 - Umidade original, partícula maior, sem inoculante bacteriano, com milheto.

${ }^{2}$ Médias na mesma linha seguidas por letras diferentes diferem entre si pelo teste de Tukey $(P<0,05) .{ }^{3}$ coeficiente de variação $(\%)$. 
Como pode ser observado para a degradabilidade da MS, tanto a efetiva $(65,53 \%)$ como a potencial $(78,07 \%)$, foram maiores $(P<0,05)$ no tratamento $\mathrm{T} 7$, devido à participação de milheto grão nestas silagens, ingrediente este com maior potencial de degradabilidade que a forragem. Também a fração "a" deste mesmo tratamento, tida como solúvel e rapidamente degradável (42,93\%), foi superior aos demais tratamentos, apesar de seu lag time e sua taxa de degradação não terem diferido $(P<0,05)$ dos demais.

\subsubsection{Degradabilidade in situ da FDN}

As variáveis sobre degradabilidade de FDN são apresentadas na Tabela 13, na qual pode ser visto que não houve efeito $(P>0,05)$ de tratamento sobre a fração "a" da FDN com valor médio de 4,12\%, valor este superior aos dados negativos obtidos por Pinto et al. (1998) e Loures (2004) e também superior aos 2,11\% relatados por Mello et al. (2002). Porém, apresentam-se abaixo dos 6,3\% observados por Manzano (2002) e dos 5,49\% de Balsalobre (2002) que utilizaram capim Tanzânia em pastejo.

A fração "a" é definida como porção solúvel e, portanto, as frações fibrosas deveriam apresentar valor "a" como sendo zero. No entanto, o valor da fração "a" demonstrada aqui foi estimativa do modelo e não determinação por lavagem, que neste caso seria próximo de zero. Sua ocorrência pode demonstrar perda de partículas por lavagem.

A fração "b" da FDN, com média de 58,77\%, não diferiu entre os tratamentos $(P>0,05)$, mas foi inferior à amplitude de 72 a $80 \%$ observada por vários autores na maioria dos trabalhos (Pinto et al., 1998; Balsalobre, 2002; Manzano, 2002; Simili et al., 2002; Loures, 2004).

A taxa de degradação de FDN obtida foi de $4,50 \% \cdot \mathrm{h}^{-1}$, média entre todos os tratamentos que não diferiram $(P>0,05)$ entre si. Este valor encontrase próximo aos 4,53\% de Loures (2004), acima da média de 3,15\% de 
Manzano (2002), porém abaixo da média de 5,54\% de Balsalobre (2002) e Mello et al. (2002).

A degradabilidade efetiva de FDN obtida foi de $37,82 \%$ não tendo efeito de tratamento $(P>0,05)$, no entanto este valor encontra-se abaixo do observado na literatura, entre 41 e 60\% (Balsalobre, 2002; Pinto et al., 1998; Simili et al., 2002; Loures, 2004).

Também não houve efeito $(P>0,05)$ de tratamento sobre a degradabilidade potencial da FDN (58,09\%), estando a média observada abaixo dos valores verificados por Manzano (2002), Balsalobre (2002), Simili et al. (2002) e Loures (2004) os quais estimaram valores entre 65 e $80 \%$.

Como mencionado, pelo fato do programa Fit Curve ter gerado alguns dados da fração "a" negativos para FDN, FDA e hemicelulose, adotou-se a postura de substituir estes valores por zero, uma vez que não há fração solúvel na fibra. Mesmo quando o dado da fração "a" foi ligeiramente positivo o modelo gerou fração "a" negativa devido a ajustes na curva de degradação. Isto vem ocorrendo para alguns autores, como Pinto et al. (1998) com capim Panicum maximum que foi de -3,69\%, Nonaka et al. (2001) que obtiveram fração "a" para a FDN de $-11,60 \%$ com alfafa e Loures (2004) que também obteve frações "a" para FDA, FDN e hemicelulose negativos.

Loures (2004) afirmou que estes valores negativos poderiam ser justificados pelo elevado erro experimental dessa mensuração, traduzido pelos valores de coeficientes de variação elevados (54 a 146\%). Isso se deve aos resíduos não uniformes resultantes da lavagem dos sacos de nailon, referentes ao tempo zero hora de incubação, utilizados na avaliação da fração solúvel em água.

Adicionalmente, a concentração reduzida de componentes solúveis nessas silagens revela a possibilidade de distorções das equações de estimativa, as quais se tornam pouco precisas quando utilizadas para substratos fibrosos. Os valores negativos para a fração "a" se devem ao fato de 
que a fração fibrosa, provavelmente em quase sua totalidade, apresenta mínima contribuição de componentes solúveis (Loures, 2004).

Guim et al. (1995) utilizando o mesmo modelo adotado no presente experimento (Orskov \& McDonald, 1979) descreveram que os ajustes para dados de degradação da MS das silagens podem ser considerados bons e coerentes com os princípios biológicos incluídos no modelo, com certa uniformidade entre tratamentos quanto à fração solúvel "a" e à fração insolúvel mas potencialmente degradável "b". Porém para degradação de FDN os ajustes não foram uniformes, embora os valores de "a" estejam muito próximos de zero (pois FDN não contém fração solúvel), devendo ser salientado que os dados da fração "a" devem ser analisados com reserva.

\subsubsection{Degradabilidade in situ da FDA}

Não houve efeito de tratamento sobre a fração "a" $(P>0,05)$ da FDA, nem para a taxa de degradação $(P>0,05)$, degradação efetiva $(P>0,05)$, degradação potencial $(P>0,05)$ e lag time $(P>0,05)$, cujos dados referentes à degradabilidade da FDA são apresentados na Tabela 14.

A fração "a" da FDA revelou média de $7,40 \%$ próxima aos 7,59\% de Manzano (2002) porém abaixo dos 9,53\% de Balsalobre (2002). A fração "b" atingiu 56,00\%, abaixo da média de $73,18 \%$ relatada na literatura (Manzano, 2002; Balsalobre, 2002; Loures, 2004), sendo que os tratamentos T4; T6 e T7 apresentaram as maiores médias $(P<0,05)$.

A taxa de degradação da FDA observada foi de $4,80 \% \cdot \mathrm{h}^{-1}$, aproximando-se aos 4,55\% de Loures (2004), abaixo dos 5,38\% de Balsalobre (2002) e superior aos 4,13\% relatado por Manzano (2002).

A degradabilidade efetiva de FDA de $41,58 \%$, esteve próxima aos 42,74\% de Loures (2004), inferior aos 43,92\% de Manzano (2002) e aos $61,44 \%$ de Balsalobre (2002). Quanto à degradabilidade potencial destra fração 
Tabela 14. Variáveis da degradabilidade in situ da FDA e hemicelulose de silagens de capim Tanzânia

\begin{tabular}{|c|c|c|c|c|c|c|c|c|c|}
\hline \multirow[b]{2}{*}{ Variáveis } & \multicolumn{9}{|c|}{ Tratamentos $^{1,2}$} \\
\hline & T1 & $\mathrm{T} 2$ & T3 & $\mathrm{T} 4$ & T5 & T6 & T7 & Médias & $\mathrm{CV}$ \\
\hline & \multicolumn{9}{|c|}{ FDA } \\
\hline a (\%) & $6,2^{\mathrm{a}}$ & $9,0^{\mathrm{a}}$ & $5,7^{\mathrm{a}}$ & $3,9^{a}$ & $9,2^{\mathrm{a}}$ & $1,8^{\mathrm{a}}$ & $6,7^{\mathrm{a}}$ & 6,1 & 115,8 \\
\hline b (\%) & $52,7^{b}$ & $50,6^{b}$ & $52,8^{b}$ & $57,8^{a}$ & $51,6^{b}$ & $57,2^{a}$ & $66,0^{a}$ & 56,0 & 11,0 \\
\hline$c\left(\% \cdot h^{-1}\right)$ & $5,0^{a}$ & $5,0^{a}$ & $4,2^{a}$ & $4,4^{a}$ & $4,3^{a}$ & $5,3^{a}$ & $5,5^{\mathrm{a}}$ & 4,8 & 23,0 \\
\hline Degradabilidade efetiva (\%) & $43,8^{a}$ & $44,49^{a}$ & $38,9^{a}$ & $39,7^{a}$ & $43,4^{a}$ & $43,1^{a}$ & $40,7^{a}$ & 41,6 & 15,3 \\
\hline Degradabilidade potencial (\%) & $58,9^{a}$ & $59,9^{a}$ & $59,0^{a}$ & $62,6^{a}$ & $61,2^{a}$ & $59,8^{a}$ & $65,7^{a}$ & 60,7 & 7,4 \\
\hline \multirow[t]{2}{*}{ Lag time (h) } & $3,5^{a}$ & $3,2^{a}$ & $1,8^{a}$ & $2,4^{a}$ & $2,6^{a}$ & $3,5^{a}$ & $1,1^{\mathrm{a}}$ & 2,6 & 59,6 \\
\hline & \multicolumn{9}{|c|}{ HEMICELULOSE } \\
\hline a $(\%)$ & $0,6^{\mathrm{a}}$ & $0,1^{\mathrm{a}}$ & $1,8^{a}$ & $0,7^{\mathrm{a}}$ & $0,5^{a}$ & $0,7^{\mathrm{a}}$ & $1,0^{\mathrm{a}}$ & 0,8 & 292,9 \\
\hline b (\%) & $68,0^{a}$ & $65,4^{a}$ & $67,5^{a}$ & $67,6^{a}$ & $68,1^{a}$ & $70,4^{a}$ & $78,1^{a}$ & 69,6 & 11,6 \\
\hline$c\left(\% \cdot h^{-1}\right)$ & $5,2^{\mathrm{a}}$ & $4,7^{\mathrm{a}}$ & $3,9^{a}$ & $4,4^{\mathrm{a}}$ & $4,4^{\mathrm{a}}$ & $5,1^{\mathrm{a}}$ & $4,8^{a}$ & 4,7 & 19,5 \\
\hline Degradabilidade efetiva (\%) & $33,5^{a}$ & $33,4^{a}$ & $27,3^{a}$ & $32,2^{a}$ & $32,0^{a}$ & $35,1^{a}$ & $31,5^{a}$ & 31,8 & 22,8 \\
\hline Degradabilidade potencial (\%) & $52,5^{b}$ & $54,7^{b}$ & $54,3^{b}$ & $59,4^{b}$ & $55,1^{b}$ & $56,6^{b}$ & $63,6^{a}$ & 55,6 & 8,8 \\
\hline Lag time (h) & $3,4^{a}$ & $3,0^{\mathrm{a}}$ & $1,29^{a}$ & $1,7^{\mathrm{a}}$ & $2,7^{\mathrm{a}}$ & $3,3^{a}$ & $1,6^{\mathrm{a}}$ & 2,6 & 59,1 \\
\hline
\end{tabular}

${ }^{1}$ T1 - Umidade original, partícula menor, sem inoculante bacteriano; T2 - Umidade original, partícula menor, com inoculante bacteriano;T3 Emurchecido, partícula maior, com inoculante bacteriano; T4 - Emurchecido, partícula maior, sem inoculante bacteriano; T5 - Umidade original, partícula maior, com inoculante bacteriano; T6 - Umidade original, partícula maior, sem inoculante bacteriano; T7 - Umidade original, partícula maior, sem inoculante bacteriano, com milheto.

${ }^{2}$ Médias na mesma linha seguidas por letras diferentes diferem entre si pelo teste de Tukey $(P<0,05) .{ }^{3}$ coeficiente de variação (\%). 
obteve-se média de 60,68\%, inferior aos $80,26 \%$ de Manzano (2002), obteve-se média de 60,68\%, inferior aos 80,26\% de Manzano (2002), aos 66,71\% de Loures (2004) e aos 79,87\% relatados por Balsalobre (2002). aos 66,71\% de Loures (2004) e aos 79,87\% relatados por Balsalobre (2002).

\subsubsection{Degradabilidade in situ da hemicelulose}

Os dados de degradabilidade da hemicelulose, apresentados na Tabela 14 , não apresentaram efeito $(P>0,05)$ de tratamento sobre as frações "a" e "b" $(P>0,05)$, nem para a taxa de degradação $(P>0,05)$, degradação efetiva $(P>0,05)$, degradação potencial $(P>0,05)$ e lag time $(P>0,05)$.

A fração "a" obtida, 0,46\%, encontra-se acima dos $-7,89 \%$ de Loures (2004). A fração "b" apresentou média de $69,62 \%$, valor inferior aos $72,76 \%$ de Loures (2004). A taxa de degradação de $4,75 \% \cdot \mathrm{h}^{-1}$ aqui obtida esteve próxima aos $4,55 \%$ de Loures (2004).

A degradabilidade efetiva da hemicelulose foi de 31,85\%, estando abaixo dos 70,97\% de Loures (2004). Quanto à degradação potencial da hemicelulose, a média do presente trabalho $(55,58 \%)$ encontra-se abaixo dos 64,89\% de Loures (2004).

Apesar das taxas de degradação obtidas para MS $\left(4,81 \% \cdot h^{-1}\right)$, FDA $\left(4,80 \% \cdot h^{-1}\right)$, FDN $\left(4,50 \% \cdot h^{-1}\right)$ e hemicelulose $\left(4,75 \% \cdot h^{-1}\right)$ no presente experimento estarem de acordo com dados de literatura, seus valores de degradabilidades efetiva e potencial apresentaram-se inferiores aos esperados, em função da fração "b" (MS, FDA, FDN) das silagens ter revelado valores abaixo das médias mencionadas por outros autores, como evidenciado pelas comparações acima.

Considerando a baixa digestibilidade apresentada pela PB (ítem 4.3.3 Digestibilidade aparente no trato digestivo) e a suposição de deficiência de $\mathrm{N}$ ruminal limitando a atividade microbiana, parece não ter se confirmado, pois 
as taxas de degradação ruminal observadas encontram-se dentro da amplitude sugerida pela literatura.

A ocorrência de valores inferiores nas estimativas das degradabilidades efetiva e potencial, parece ser justificável, ao menos em parte, pela maior idade de rebrota do capim utilizado quando comparado com outros trabalhos científicos.

Além disso, vale ressaltar que os valores de degradabilidade (efetiva e potencial) da FDA, FDN e HEMI apresentaram-se elevados em relação a aos valores de degradabilidade da MS, ou seja, as frações fibrosas se aproximam muito da MS. Também a fração "b" para todas as frações fibrosas apresentaram-se superiores à mesma fração da MS, fatos esses não coerentes.

Essa tendência não pode ser considerada coerente exceto para situação onde a fração de carboidratos e proteína solúveis da planta fosse muito reduzida, de forma que a fração fibrosa representasse quase a totalidade da MS como ocorre em plantas mais velhas.

\subsubsection{Desaparecimento intestinal}

Na Tabela 15 são apresentados os dados relativos à digestão intestinal obtidos pela técnica do saco de náilon móvel. Houve efeito de tratamento sobre o desaparecimento intestinal de MS e FDN $(P<0,05)$, apenas para o tratamento T7 original, que apresentou as maiores médias devido à presença de milheto grão moído na sua composição.

Os elevados coeficientes de variação observados na Tabela 14 podem ser atribuídos a dois fatores, o primeiro deve-se ao fato de que alguns tratamentos tiveram baixa recuperação dos sacos de náilon nas fezes, pela dificuldade de serem encontrados ou porque foram excretados após ter encerrado o tempo de coleta. Outro motivo pode ter sido decorrente da falta de homogeneidade nas amostras, uma vez que os sacos de náilon continham quantidade limitada de resíduo. 
Como era esperado, as silagens sem pré-degradação ruminal apresentaram maior desaparecimento das frações MS, FDA e FDN durante passagem pelo intestino, em comparação à silagem pré-degradada no rúmen por 12 horas (Tabela 14), pois continham as frações solúvel e rapidamente degradável intactas, enquanto que o material pré-degradado no rúmen por 12 horas já havia perdido estas frações por ação microbiana ruminal, restando apenas material de mais difícil digestão.

Evidenciar a perda por solubilidade foi o único objetivo ao se introduzir sacos de náilon no duodeno contendo material na sua composição original, pois no caso dos ruminantes sabe-se que a forragem tem sua composição alterada ao passar pelo rúmen. Assim para efeitos de cálculos utilizaram-se apenas os dados obtidos dos sacos de náilon que continham silagens pré-degradadas no rúmen, mantendo a composição original como referência.

Somando-se a percentagem de degradação efetiva ruminal da silagem (Tabela 13) com a percentagem de desaparecimento intestinal no material prédegradado (Tabela 14) deveria resultar em um valor próximo ao da digestibilidade aparente por coleta total que foi de $61,40 \%$ para MS, de $60,34 \%$ para FDN e de $59,69 \%$ para FDA (Tabela 10 ).

Porém, as diferenças foram muito acentuadas entre estes valores de digestibilidade no trato total e aqueles obtidos pela soma algébrica (degradação efetiva + desaparecimento intestinal), tanto para MS (51,85\%) como para FDA $(45,94 \%)$ e FDN $(40,86 \%)$.

Assim, subtraindo-se da digestibilidade aparente no trato total a degradabilidade efetiva ruminal, resta para os intestinos a responsabilidade de digestão de toda diferença para chegar-se a valores de digestibilidade total.

Os valores de desaparecimento intestinal aqui obtidos por diferença são bem superiores aos 5 a $10 \%$ que cabem tradicionalmente ao intestino (Huhtanen \& Vanhatalo, 1997). Com isso, deduz-se que houve, em alguma porção do trato digestivo, uma super ou subestimação das digestibilidades da MS, FDA e FDN. 
Tabela 15. Desaparecimento intestinal e estimativa de degradação no trato total de frações fibrosas de amostras de silagens de capim Tanzânia, com composição original ou pré-degradadas no rúmen por 12 horas

\begin{tabular}{|c|c|c|c|c|c|c|c|c|c|c|}
\hline & \multicolumn{10}{|c|}{ Tratamentos $^{1,2}$} \\
\hline & Variável & $\mathrm{T} 1$ & $\mathrm{~T} 2$ & T3 & $\mathrm{T} 4$ & T5 & T6 & T7 & Média & $\mathrm{CV}^{3}$ \\
\hline \multirow[t]{4}{*}{ MS } & Original & $16,6^{b}$ & $17,5^{b}$ & $15,0^{b}$ & $14,2^{b}$ & $15,9^{b}$ & $16,4^{b}$ & $55,1^{a}$ & 23,3 & 22,3 \\
\hline & Pré degradada (1) & $6,2^{a}$ & $5,9^{a}$ & $7,4^{\mathrm{a}}$ & $5,2^{a}$ & $4,8^{a}$ & $4,7^{\mathrm{a}}$ & $10,3^{a}$ & 5,9 & 40,7 \\
\hline & Deg. Efetiva ruminal(2) & $43,60^{b}$ & $43,4^{b}$ & $40,4^{b}$ & $40,1^{b}$ & $42,2^{b}$ & $42,6^{b}$ & $65,5^{a}$ & 46,0 & 6,7 \\
\hline & $1+2^{4}$ & $49,8^{b}$ & $49,3^{b}$ & $47,8^{b}$ & $45,3^{b}$ & $46,9^{b}$ & $47,2^{b}$ & $75,9^{a}$ & 51,9 & 12,9 \\
\hline \multirow[t]{4}{*}{ FDN } & Original & $6,78^{b}$ & $9,4^{\mathrm{b}}$ & $4,6^{b}$ & $0,2^{b}$ & $4,8^{b}$ & $9,6^{\mathrm{b}}$ & $27,1^{a}$ & 10,0 & 68,1 \\
\hline & Pré degradada (1) & $2,0^{a}$ & $2,7^{\mathrm{a}}$ & $4,75^{a}$ & $4,1^{a}$ & $2,0^{\mathrm{a}}$ & $2,6^{\mathrm{a}}$ & $4,4^{a}$ & 3,0 & 77,2 \\
\hline & Deg. Efetiva ruminal(2) & $39,1^{a}$ & $39,7^{a}$ & $35,89^{a}$ & $35,1^{a}$ & $38,6^{a}$ & $39,6^{a}$ & $40,7^{a}$ & 37,8 & 21,2 \\
\hline & $1+2$ & $41,1^{a}$ & $42,4^{a}$ & $40,4^{a}$ & $39,28^{a}$ & $40,6^{a}$ & $42,2^{a}$ & $45,25^{a}$ & 40,9 & 24,1 \\
\hline \multirow[t]{4}{*}{ FDA } & Original & $12,67^{\mathrm{a}}$ & $14,4^{a}$ & $9,9^{a}$ & $8,8^{a}$ & $13,0^{a}$ & $12,6^{a}$ & $23,7^{a}$ & 13,8 & 52,2 \\
\hline & Pré degradada (1) & $4,9^{a}$ & $6,5^{\mathrm{a}}$ & $6,46^{a}$ & $4,4^{a}$ & $3,6^{a}$ & $3,7^{\mathrm{a}}$ & $7,8^{\mathrm{a}}$ & 4,46 & 48,7 \\
\hline & Deg. Efetiva ruminal(2) & $43,8^{a}$ & $44,4^{a}$ & $39,0^{a}$ & $39,79^{a}$ & $43,4^{a}$ & $43,1^{a}$ & $40,7^{a}$ & 41,6 & 15,3 \\
\hline & $1+2$ & $48,8^{a}$ & $50,9^{a}$ & $45,3^{a}$ & $44,1^{a}$ & $47,0^{\mathrm{a}}$ & $46,87^{\mathrm{a}}$ & $48,4^{a}$ & 46,0 & 21,7 \\
\hline
\end{tabular}

${ }^{1}$ T1 - Umidade original, partícula menor, sem inoculante bacteriano; T2 - Umidade original, partícula menor, com inoculante bacteriano; T3 Emurchecido, partícula maior, com inoculante bacteriano; T4 - Emurchecido, partícula maior, sem inoculante bacteriano; T5 - Umidade original, partícula maior, com inoculante bacteriano; T6 - Umidade original, partícula maior, sem inoculante bacteriano; T7 - Umidade original, partícula maior, sem inoculante bacteriano, com milheto.; ${ }^{2}$ Médias na mesma linha seguidas por letras diferentes diferem entre si pelo teste de Tukey $(\mathrm{P}<0,05) ;{ }^{3}$ coeficiente de variação $(\%) ;{ }^{4}$ Degradação no trato total $(\%)=$ soma da Degradação Efetiva ocorrida no rúmen (\%) com o desaparecimento intestinal da silagem pré-degradada no rúmen por 12 horas (\%). 
Há duas hipóteses para tentar explicar este fato. Pode ter ocorrido menor extensão de digestão do material pré-degradado que foi para o duodeno, diferente do que ocorreria num fluxo normal da digesta pelo intestino.

Huhtanen \& Vanhatalo (1997) já mencionaram que há limitação quanto ao uso de sacos móveis para determinação de digestibilidade intestinal. Limitação esta (microbiana e enzimática) no acesso do fluido intestinal ao interior da amostra seca dentro do saco de náilon, fazendo com que este percorra uma certa distância no intestino até ter seu conteúdo totalmente embebido pelo suco intestinal e ser iniciada a digestão. No caso do alimento que foi inserido na sua composição original, o maior desaparecimento foi devido provavelmente à maior proporção de frações intactas perdidas por solubilidade e não por ação digestiva.

Por outro lado Huhtanen \& Vanhatalo (1997) também mencionam outra limitação do método, que é o maior tempo médio de permanência no intestino para estes sacos de náilon do que o tempo de retenção normal da digesta, levando à super estimação da digestão da FDN intestinal, principalmente se o nível de ingestão for baixo, tornando-se muito crítica a avaliação das frações fibrosas. Essa segunda limitação de certo modo viria compensar a primeira, ou seja, o atraso no início da digestão intestinal seria compensado por maior tempo de permanência.

Como as médias de digestibilidade intestinal obtidas para MS $(5,90 \%)$, FDN $(3,04 \%)$ e FDA $(4,36 \%)$ encontram-se dentro dos preconizados de 5 a 10\% (Huhtanen \& Vanhatalo, 1997), então, uma segunda hipótese é que tenha ocorrido baixa degradação efetiva ruminal. Se esse for o caso, admitindo-se valores de degradação ruminal superiores, haveria menor expectativa para a digestão no intestino, chegando a valores mais coerentes de digestibilidade em cada porção para compor a digestibilidade no trato total.

Como discutido previamente no ítem 4.3.5 Degradabilidade in situ, os valores obtidos neste trabalho para as degradabilidades efetiva e potencial estão abaixo do que se relata na literatura, devido ao baixo valor da fração "b" 
que estas silagens apresentaram. Isso ocorreu tanto para MS quanto para FDA e FDN. Assim, se as degradabilidades efetivas tivessem sido maiores, talvez a diferença para se chegar à digestibilidade total fosse mais coerente.

\subsection{Conclusões}

A adoção do emurchecimento, alteração no tamanho de partícula e uso de inoculante bacteriano em silagens de capim Tanzânia não causaram efeitos consistentes nas variáveis de consumo, cinética ruminal, degradação e parâmetros de fermentação ruminal digestibilidade e comportamento ingestivo.

As alterações nas variáveis ruminais promovidas pela adição de milheto à ensilagem do capim Tanzânia parecem ser mais relacionadas com a contribuição de fonte de carboidrato fermentável do que pela redução de umidade causada por esse aditivo.

As respostas observadas na digestão de nutrientes e comportamento ingestivo pelos animais foram condicionadas à maior participação de silagens de capim Tanzânia à ração.

Esses resultados estabelecem uma perspectiva de desempenho individual de animais e indicam o potencial para ampliação com maiores proporções de inclusão de ingredientes concentrados à ração. 


\section{EFEITO DO TAMANHO DE PARTÍCULA, TEOR DE MATÉRIA SECA E INOCULANTE BACTERIANO SOBRE OS PARÂMETROS FÍSICOS E PERDAS POR DETERIORAÇÃO, EM SILAGEM DE CAPIM TANZÂNIA ARMAZENADA EM SILOS TUBULARES REVESTIDOS POR LONA PLÁSTICA, E SOBRE O DESEMPENHO DE BOVINOS DE CORTE}

\section{Resumo}

O objetivo desse trabalho foi avaliar o efeito do tamanho de partícula, teor de matéria seca e uso de inoculante bacteriano sobre as propriedades físicas e perdas por deterioração da silagem de capim Tanzânia. Adicionalmente, a ingestão de MS, ganho de peso e conversão alimentar de novilhas alimentadas com rações completas contendo silagem de capim Tanzânia foi avaliado. Os tratamentos adotados foram: T1: Umidade original, partícula maior, sem inoculante bacteriano; T2: Umidade original, partícula menor, sem inoculante bacteriano; T3: Emurchecido, partícula maior, sem inoculante bacteriano; T4: Umidade original, partícula maior, sem inoculante + milheto grão moído; T5: Umidade original, partícula menor, com inoculante bacteriano. A redução no tamanho da partícula não elevou as densidades de matéria seca (DMS) e matéria verde (DMV), embora a adição de milheto grão moído tendeu aumentar a DMS $\left(156 \mathrm{~kg} \cdot \mathrm{m}^{-3}\right)$ em relação aos demais tratamentos. O emurchecimento tendeu a diminuir a DMV $\left(460 \mathrm{~kg} \cdot \mathrm{m}^{-3}\right) \mathrm{em}$ relação aos demais tratamentos, porém, esta redução não foi suficiente para diminuir a DMS, compensada pelo maior teor de MS. A redução no tamanho de partículas (silagens T2 e T5) não reduziu a porosidade, contrariando as expectativas, talvez devido à substituição de menor número de poros de maior 
tamanho por maior número de poros menores. O tratamento emurchecido (T3) apresentou maiores perdas quando comparado com o tratamento adicionado com milheto grão (29.1 vs $17.9 \%$ ). Não houve efeito da redução no tamanho de partícula $(P=0,60)$ na redução de perdas mas houve tendência $(P=0,09)$ de aumento nas perdas na presença do inoculante bacteriano. Não houve efeito da redução no tamanho de partícula, do uso de inoculante bacteriano e alteração no teor de MS sobre a ingestão de matéria seca (2,36\% PV), ganho de peso (1,03 kg.animal.dia $\left.{ }^{-1}\right)$ e conversão alimentar (7,91 kg MS.kg GPV $\left.{ }^{-1}\right)$. Houve tendência $(P=0,06)$ de melhora no desempenho animal (ingestão e ganho de peso) com o fornecimento de silagem emurchecida aos animais em comparação ao tratamento que foi adicionado milheto na ensilagem, sendo a silagem emurchecida a que apresentou maiores perdas após abertura do silo dentre todos os tratamentos. Esses dados sugerem que o emurchecimento pode não ser um método recomendável na ensilagem de gramíneas tropicais, quando colhidas sob tamanho de partícula maior e armazenadas em silos tubulares revestidos por lona plástica. As estratégias de ensilagem estabelecidas em silagens de capim Tanzânia não resultaram alterações significativas no desempenho animal. Alguns desses dados contrariam dados encontrados na literatura e devido a isso sugere-se que a decisão deve ser baseada no controle de perdas desde a colheita até o desempenho animal.

\section{EFFECTS OF PARTICLE SIZE, DRY MATTER CONTENT AND BACTERIAL INOCULANT ON THE PHYSICAL PARAMETERS AND UNLOADING LOSSES OF TANZANIA GRASS SILAGE STORED IN PRESSED BAG SILOS AND THE PERFORMANCE OF BEEF CATTLE}

Summary

The main objective was to study the effect of particle size, dry matter content and the addition of bacterial inoculant in the ensiling of Tanzania grass 
(Panicum maximum, Jacq. cv. Tanzânia) on the physical characteristics and losses occurred during silo unloading. Additionally, the DM intake, weight gain and feed conversion of beef heifers fed TMR containing grass silage was measured. Treatments were described as follows: T1: wet forage, large particle; T2: wet forage, smaller particle; T3: wilted, large particle; T4: T1 + ground pearl millet grain; T5: T2 + bacterial inoculant. The small particle size in the forage did not increased both, wet and DM silages bulk densities, even tough the addition of pearl millet grain showed a trend for higher DM density (156 kg. $\mathrm{m}^{-3}$ ) compared to the other. The forage wilting tended to lower the wet density of the silage $\left(460 \mathrm{~kg} \cdot \mathrm{m}^{-3}\right)$ which, however, was not enough to reduce the DM density due to the compensatory effect established by the higher DM content. By reducing the particle size in the forage (T2 e T5) did not reduced the porosity, in opposition to the expected results. It might be a rule between fewer and larger pores volumes which were compensated by many smaller pores. The wilted forage (T3) showed higher losses when compared to the addition of pearl millet (29.1\% vs $17.9 \%)$. Particle size reduction did not changed the unloading losses $(P=0,60)$ but the addition of bacterial inoculant showed a trend $(P=0,09)$ for increased losses. No significantly differences were observed for the reduction of particle size, bacterial inoculation or changes in the DM content of silages on animal DM intake (2.4\%BW), body weight gain (1,03 kg.animal.day-1) and feed conversion $\left(7,91 \mathrm{~kg} \mathrm{MS.kg} \mathrm{BWG}{ }^{-1}\right)$. There was a trend for improved animal performance (intake and $B W G)(P=0.06)$ when wilted silage was fed in comparison to the pearl millet added silage, however the wilted silage showed the highest silo unloading losses across all treatments. These data suggest that wilting may not be a suitable method for ensiling tropical grass silage, harvested under larger particles in pressed bag silos. The ensiling strategies established in Tanzânia grass silages did not result in significant changes in animal performance. Some of these data are in conflict with the updated literature and because of this it might be suggested a decision based on the overall control of losses from the forage harvesting stage through the animal performance. 


\subsection{Introdução}

Gramíneas, apesar de se apresentarem como cultura alternativa para a confecção de silagens, exibem algumas características limitantes ao processo, como elevado teor de umidade e baixo teor de carboidratos solúveis (Balsalobre et al., 2001), o que estimula fermentações indesejáveis, gerando elevadas perdas quantitativas e qualitativas, limitando o consumo pelos animais.

Essas limitações podem ser contornadas com a adoção de técnicas como por exemplo a elevação do teor de matéria seca pelo emurchecimento ou pela adição de material absorvente. A elevação no teor de matéria seca, não somente previne perdas e fermentações indesejáveis como também pode elevar o consumo pelos animais (Lavezzo, 1985; Narciso Sobrinho et al., 1998b).

No caso do emurchecimento, sua adoção melhora as características de fermentação da silagem, promove alterações na ingestão de forragem e desempenho animal. Porém, os benefícios dependerão das condições de clima predominantes durante este procedimento no campo. A magnitude de resposta ao emurchecimento, em relação à ingestão pelos animais, está intimamente relacionada com a taxa de secagem no campo e o aumento no teor de matéria seca, sobrepondo-se aos efeitos diretos de fermentação da silagem (Dawson et al., 1999; Wright et al., 2000; Keady \& Mayne, 2001).

Segundo Jones \& Jones (1995) em forragens com teores de matéria seca acima de $28 \%$ não há perdas por efluente, que sendo rico em compostos solúveis ( $\mathrm{N}$, açúcares, produtos da fermentação), resultaria em perda de nutrientes digestíveis (Holmes \& Mathews, 2001).

A adição de material com poder absorvente, como cereais moídos e polpa cítrica, é uma alternativa ao emurchecimento. Teria a vantagem de não exigir operação extra no recolhimento da forragem e não apresenta o risco de perder a forragem picada por ocorrência de chuvas durante a desidratação. 
Também o processamento mecânico grosseiro impede a eficiente compactação gerando dentro do silo condições não favoráveis à boa fermentação. Assim outra prática recomendável seria a redução do tamanho de partículas que tem efeito benéfico na qualidade de fermentação, melhorando a densidade, a área de superfície disponível para o ataque dos microrganismos e criando condições de anaerobiose mais rapidamente. Contudo, apesar do processamento mecânico mais intenso reduzir as perdas por gases, pode aumentar as perdas por efluente (Aguiar et al., 2000).

Além dos procedimentos acima citados uma alternativa visando reduzir perdas após abertura do silo seria aumentar as taxas de retirada da silagem, que são determinadas pelo consumo diário e dimensionamento do silo (McDonald, 1981).

Marsh (1979) observou que somente em $25 \%$ dos casos estudados houve o benefício do emurchecimento sobre a digestibilidade, com aumento da ingestão de matéria seca. Com isso evidenciou que a elevação na produção animal confirma que o aumento na ingestão de matéria seca supera a possível desvantagem de menores coeficientes de digestibilidade.

Ao contrário, Wright et al. (2000) descreveram que o aumento na ingestão de matéria seca procuraria compensar a menor ingestão de nutrientes, os quais são perdidos durante o emurchecimento, não havendo, entretanto, melhoria no desempenho animal.

Outro método adotado na ensilagem com o objetivo de controlar fermentações indesejáveis dentro do silo é o uso de inoculante bacteriano. Embora os resultados tenham sido bastante variáveis, tanto em relação à ingestão de matéria seca quanto ao desempenho de animais (Dawson et al., 1999), o que pode levar a questionamento na sua adoção.

Vilela (1998) mencionou que os resultados decorrentes do uso de inoculantes bacterianos sobre o consumo, ganho de peso e produção de leite revelaram aumentos da ordem de 2 a 4\%, concordando com acréscimos de 2 a 
5\% reportados por Haigh (1998) quando da utilização desses aditivos, não sendo esses números muito significativos.

Porém, existem outros trabalhos nos quais o efeito do inoculante é bem pronunciado, como no caso de Winters et al. (2001), que observou que silagens de azevém inoculadas permitiram maior consumo e o ganho de peso foi $35 \%$ superior ao controle, melhorando também a conversão alimentar. Esse resultado foi atribuído à limitada degradação protéica da silagem, pela rápida queda no $\mathrm{pH}$, inibindo a atividade enzimática e reprimindo o crescimento de bactérias que degradam proteínas.

Embora nem sempre o uso de inoculante determine menor $\mathrm{pH}$ na silagem, pode elevar os teores dos ácidos lático e acético e reduzir o de ácido propiônico, proporcionando maiores ingestão e ganho de peso (Clavero, 2001).

Apesar do inoculante não apresentar nenhum benefício em estabilidade aeróbia após abertura, em um terço dos estudos apresentados por Muck \& Kung Jr. (1997) aumentou a digestibilidade da matéria seca.

A estabilidade aeróbia da silagem pode não ser melhorada com a utilização de inoculantes bacterianos e, em alguns casos, até ocorre o contrário, porque o ácido lático, por si só, não é um agente antimicótico efetivo, podendo ser usado por leveduras como substrato para o crescimento durante a exposição aeróbia.

Kung Jr \& Ranjit (2001) comprovaram este efeito mostrando que silagem inoculada com bactérias homoláticas apresentou sinais de deterioração em metade do tempo em relação àquela não inoculada.

Com a aeração na abertura do silo os microrganismos aeróbios se multiplicam e passam a dominar, levando à deterioração da silagem evidenciada pelo aquecimento da massa e aparecimento de fungos, que causam fermentações secundárias, ocasionando perdas físicas de silagem e degradação de nutrientes.

Silagens mais propícias à deterioração aeróbia são aquelas que têm maior teor de carboidrato residual, nas quais foi usado aditivo ou foram 
intensivamente emurchecidas (McDonald, 1981). Entretanto, Loures et al. (2003c) obtiveram melhor estabilidade aeróbia em silagem de capim Tanzânia emurchecido que com o material original, o que é um importante efeito na redução de perdas após abertura dos silos, resultando em forragem de maior qualidade sendo oferecida aos animais.

No que diz respeito a diferentes tipos de silos, Rony et al. (1984) compararam silos tipo torre e tipo tubulares revestidos por lona plástica (bag). Os autores observaram que as perdas de matéria seca total foram maiores para silagem de gramínea que para a de milho, o que pode ter relação com a alta temperatura ocorrida nesses silos durante a fermentação. Parte desse efeito se deve ao fato de que no silo tipo bag o material não fica perfeitamente acomodado como num silo torre, retendo mais ar na massa, promovendo respiração mais intensa. Apesar disso, não houve diferença entre a composição química para silagens nos diferentes tipos de silo.

O objetivo deste experimento foi avaliar como o tamanho de partícula, teor de matéria seca e uso de inoculante bacteriano interferem no consumo e desempenho de novilhas de corte, nas propriedades físicas e nas perdas por deterioração da silagem de capim Tanzânia.

\subsection{Material e Métodos}

\subsubsection{Local do experimento}

O experimento foi conduzido no Departamento de Zootecnia - Setor de Ruminantes, na USP/ESALQ, Piracicaba/SP. A forragem foi colhida de uma área estabelecida com capim Tanzânia (Panicum maximum cv Tanzânia) exclusivamente destinada à ensilagem e as análises foram realizadas no Laboratório de Bromatologia, pertencente ao mesmo Departamento. 


\subsubsection{Tratamentos adotados}

Em abril de 2002 a forragem, com aproximadamente 90 dias de crescimento vegetativo, foi colhida para a confecção das silagens. Os tratamentos impostos foram os seguintes:

T1: Umidade original, partícula maior, sem inoculante bacteriano;

T2: Umidade original, partícula menor, sem inoculante bacteriano;

T3: Emurchecido, partícula maior, sem inoculante bacteriano;

T4: Umidade original, partícula maior, sem inoculante + milheto;

T5: Umidade original, partícula menor, com inoculante bacteriano.

A forragem foi colhida com uma colhedora de forragem marca CASALE ${ }^{\circledR}$. Modelo CF 2000 Super, tracionada por trator, tendo seus conjuntos de facas afiados antes da colheita.

Os silos utilizados foram do tipo tubulares (PACIFILBAG ${ }^{\circledR}$ ) revestidos por lona plástica (tipo bag), com $60 \mathrm{~m}$ de comprimento e 2,7 m de diâmetro. Tendo em vista a necessidade de forragem para cada tratamento de aproximadamente $40 \mathrm{t}$, foram confeccionados silos de aproximadamente $8 \mathrm{~m}$ de comprimento.

A acondicionadora tubular utilizada para prensagem da forragem e confecção da seção tubular era da marca IMPLECOR ${ }^{\circledR}$ (Implecor Indústria Metalúrgica AS, Argentina), Modelo b9070, Série 1997, Cajá FG, número 805. Para a operação foram definidas, a rotação do motor do trator de $2100 \mathrm{rpm}$ e a

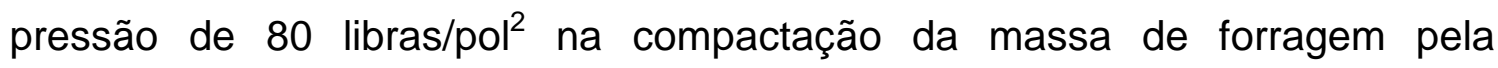
acondicionadora tubular.

\subsubsection{Confecção dos silos e aplicação dos tratamentos}

a) Forragem com teor de umidade original

Tratamentos com teor de umidade original compreenderam a forragem fresca submetida ao corte direto e ensilagem subseqüente. 


\section{b) Forragem emurchecida}

Neste caso o procedimento foi o de ceifar a forragem por volta das 9 horas da manhã, quando o excesso de orvalho já havia se dissipado. A janela traseira da colhedora, sobre as facas coletoras móveis, foi aberta de modo que a forragem ceifada não fosse enviada às facas do rotor, mas lançada para trás, em direção aos resíduos das touceiras. A forragem permaneceu exposta ao sol por aproximadamente 6 horas para a desidratação.

Ao final deste período, foram realizados ajustes nas distâncias das contra-facas do rotor de modo que ao coletar a forragem emurchecida esta fosse picada respeitando o tamanho de partículas impostos. O período de 6 horas de emurchecimento, a que foi submetida a forragem, foi baseado em experiência prévia (Igarasi, 2002), como período suficiente para elevar o teor de matéria seca até o nível desejado de 30\%, aproximadamente .

c) Adição de milheto grão moído

Com a adição de milheto grão moído à forragem com umidade original procurou-se obter mistura homogênea para atingir teor de matéria seca próximo ao do tratamento emurchecido, em torno de $30 \%$. Como o teor de matéria seca da forragem, obtida pelo corte direto, encontrava-se em torno de $20 \%$ no momento da ensilagem, para atingir teores próximos a 30\% de MS, foram adicionados aproximadamente $16 \mathrm{~kg}$ de milheto finamente moído para cada 100 $\mathrm{kg}$ de forragem fresca, no momento da ensilagem, distribuindo o milheto na superfície da massa de forragem na plataforma de admissão da ensiladora.

d) Aplicação de inoculante bacteriano

$\mathrm{O}$ inoculante bacteriano utilizado foi o $\mathrm{ECOSYL}^{\circledR}$ Silage Inoculant, da empresa ECOSYL ${ }^{\circledR}$ Products Ltda. (Registered in England No. 3155665), caracterizado como uma cepa de Lactobacillus plantarum, na forma de pó desidratado, com nível de garantia de 20 bilhões de UFC. $g^{-1}$ de produto. A diluição foi realizada seguindo-se recomendação do fabricante visando o fornecimento $10^{5}$ UFC. $g^{-1}$ de forragem, sendo a diluição realizada em água 
destilada, aplicando a solução uniformemente sobre a forragem na esteira da ensiladora, com uma bomba costal.

e) Tamanho de partícula

Foi obtido explorando-se as amplitudes máxima e mínima de distância entre as contra-facas do rotor picador.

Durante a ensilagem amostras de forragem foram tomadas, formando uma amostra composta por tratamento. Os dados de composição da forragem são apresentados na Tabela 16.

Os dados de composição do material no momento da ensilagem, apresentados na Tabela 16, foram obtidos de amostras de forragem colhidas no caminhão, portanto, no caso do tratamento 4 em que houve adição de milheto, este material foi coletado antes desta adição, pois a adição deste ingrediente foi realizada posteriormente na plataforma de admissão da ensiladora. 
Tabela 16. Composição químico-bromatológica e variáveis físicas da forragem ensilada em silos tubulares revestidos por lona plástica

\begin{tabular}{|c|c|c|c|c|c|}
\hline \multirow[b]{2}{*}{ Variáveis $^{2}$} & \multicolumn{5}{|c|}{ Forragem $^{1}$} \\
\hline & $\mathrm{T} 1$ & $\mathrm{~T} 2$ & T3 & $\mathrm{T} 4$ & T5 \\
\hline MS, $\%$ & 20,4 & 18,3 & 23,8 & 19,0 & 18,7 \\
\hline $\mathrm{CZ}, \% \mathrm{MS}$ & 10,3 & 10,8 & 10,9 & 10,6 & 10,9 \\
\hline $\mathrm{PB}, \% \mathrm{MS}$ & 12,1 & 11,4 & 9,8 & 9,6 & 11,0 \\
\hline FDN, \% MS & 67,1 & 67,4 & 71,4 & 69,8 & 68,1 \\
\hline FDA, \% MS & 41,7 & 43,1 & 43,9 & 44,5 & 42,7 \\
\hline LIG, \% MS & 4,2 & 4,4 & 5,1 & 4,6 & 4,9 \\
\hline HEM, \% MS & 25,9 & 24,36 & 26,0 & 24,9 & 25,2 \\
\hline CEL, \% MS & 37,1 & 37,6 & 39,1 & 39,5 & 37,4 \\
\hline $\mathrm{N}-\mathrm{FDA}, \% \mathrm{~N}$ total & 16,4 & 13,2 & 17,7 & 16,2 & 18,8 \\
\hline CS, \% MS & 6,4 & 4,6 & 0,9 & 3,4 & 2,3 \\
\hline Partícula (cm) & 4,0 & 3,6 & 4,0 & 3,8 & 3,8 \\
\hline CE $\left(\mathrm{mS} . \mathrm{cm}^{-1}\right)$ & 1,1 & 0,9 & 0,7 & 0,8 & 0,7 \\
\hline $\mathrm{pH}$ & 5,6 & 5,4 & 7,9 & 5,6 & 6,3 \\
\hline PT, mequiv. 100gMS ${ }^{-1}$ & 30,5 & 35,9 & 22,2 & 33,9 & 32,2 \\
\hline \multicolumn{6}{|c|}{$\begin{array}{l}\text { T1: Umidade original, partícula maior, sem inoculante bacteriano; T2: Umidade original, } \\
\text { partícula menor, sem inoculante bacteriano; T3: Emurchecido, partícula maior, sem inoculante } \\
\text { bacteriano;T4: Umidade original, partícula maior, sem inoculante + milheto; T5: Umidade } \\
\text { original, partícula menor, com inoculante bacteriano. }\end{array}$} \\
\hline \multicolumn{6}{|c|}{$\begin{array}{l}{ }^{2} \mathrm{MS}=\text { matéria seca; } \mathrm{CZ}=\text { cinzas; } \mathrm{PB}=\text { proteína bruta; FDN = fibra em detergente neutro; FDA } \\
=\text { fibra em detergente ácido; } \mathrm{LIG}=\text { lignina; } \mathrm{HEMI}=\text { hemicelulose; } \mathrm{CEL}=\text { celulose; N-FDA = } \\
\text { nitrogênio insolúvel em FDA; CS = carboidrato solúvel; } \mathrm{PT}=\text { poder tampão; } \mathrm{CE}=\text { condutividade } \\
\text { elétrica; } \mathrm{N}-\mathrm{NH}_{3}=\text { nitrogênio amoniacal. }\end{array}$} \\
\hline
\end{tabular}

$\mathrm{Na}$ Tabela 17 são apresentados dados sobre a composição das silagens. 
Tabela 17. Composição química das silagens de capim Tanzânia e do milheto utilizado

\begin{tabular}{|c|c|c|c|c|c|c|}
\hline \multirow[b]{2}{*}{ Variável $^{2}$} & \multicolumn{5}{|c|}{ Silagens $^{1}$} & \multirow[b]{2}{*}{ Milheto } \\
\hline & $\mathrm{T} 1$ & $\mathrm{~T} 2$ & T3 & T4 & T5 & \\
\hline MS, \% MS & 24,8 & 24,0 & 27,67 & 28,5 & 24,0 & 0,9 \\
\hline $\mathrm{CZ}, \% \mathrm{MS}$ & 10,9 & 10,5 & 11,2 & 8,3 & 10,8 & 2,7 \\
\hline $\mathrm{PB}, \% \mathrm{MS}$ & 9,2 & 10,2 & 9,6 & 11,0 & 8,5 & 15,2 \\
\hline FDN, \% MS & 67,8 & 69,4 & 69,0 & 49,8 & 69,3 & 14,0 \\
\hline FDA, \% MS & 45,0 & 45,4 & 46,4 & 33,7 & 45,4 & 6,9 \\
\hline LIG, \% MS & 4,9 & 5,4 & 4,9 & 3,6 & 5,0 & 2,3 \\
\hline HEMI, \% MS & 23,4 & 23,5 & 23,0 & 16,0 & 24,2 & 7,1 \\
\hline CEL, \% MS & 41,4 & 40,9 & 42,2 & 30,9 & 41,8 & 4,6 \\
\hline $\mathrm{N}-\mathrm{FDA}, \% \mathrm{~N}$ total & 13,8 & 11,3 & 11,8 & 9,8 & 14,1 & 20,0 \\
\hline $\mathrm{CS}, \% \mathrm{MS}^{3}$ & 1,8 & 1,8 & 2,4 & 1,4 & 1,2 & - \\
\hline Partícula (cm) & 2,4 & 2,2 & 3,4 & 2,2 & 2,0 & - \\
\hline Retenção na peneira, \% & 47,4 & 53,1 & 67,4 & 54,0 & 36,9 & - \\
\hline $\mathrm{pH}$ & 4,9 & 4,9 & 4,8 & 4,8 & 4,7 & - \\
\hline $\mathrm{N}-\mathrm{NH} 3, \% \mathrm{~N}$ total & 8,2 & 5,8 & 4,6 & 2,4 & 10,1 & - \\
\hline \multicolumn{7}{|c|}{$\begin{array}{l}\text { }{ }^{1} \text { T1: Umidade original, partícula maior, sem inoculante bacteriano; T2: Umidade original, } \\
\text { partícula menor, sem inoculante bacteriano; T3: Emurchecido, partícula maior, sem inoculante } \\
\text { bacteriano;T4: Umidade original, partícula maior, sem inoculante + milheto; T5: Umidade } \\
\text { original, partícula menor, com inoculante bacteriano. } \\
{ }^{2} \mathrm{MS}=\text { matéria seca; } \mathrm{CZ}=\text { cinzas; } \mathrm{PB}=\text { proteína bruta; } \mathrm{FDN}=\text { fibra em detergente neutro; FDA } \\
=\text { fibra em detergente ácido; } \mathrm{LIG}=\text { lignina; } \mathrm{HEMI}=\text { hemicelulose; } \mathrm{CEL}=\text { celulose; } \mathrm{N}-\mathrm{FDA}= \\
\text { nitrogênio insolúvel em FDA; CS = carboidrato solúvel; } \mathrm{N}-\mathrm{NH}_{3}=\text { nitrogênio amoniacal; retenção } \\
\text { na peneira = retenção (\%) na peneira superior durante a estratificação para determinação do } \\
\text { tamanho médio de partícula. }\end{array}$} \\
\hline
\end{tabular}




\subsubsection{Animais, instalações e rações}

As instalações consistiram de 20 baias com bebedouro automático e comedouro, com piso pavimentado e metade da área coberta.

Foram utilizadas 58 novilhas, sendo metade da raça Canchim, com peso vivo médio inicial de $324 \mathrm{~kg}$ e metade da raça Nelore, com peso vivo médio inicial de $291 \mathrm{~kg}$, divididas em dois blocos, leves e pesadas, dentro de raças. Foram utilizadas fêmeas porque era o que havia de disponível no momento.

Os animais permaneceram nas instalações por 20 dias, durante 0 período de adaptação, recebendo ração única, à base de silagem de capim. Ao final deste período (02/07/02) tiveram início as atividades do confinamento, com a pesagem inicial dos animais, em jejum prévio exclusivo de alimento por 12 horas. As novilhas foram distribuídas nas baias, objetivando três animais por baia, quatro baias por tratamento (duas Nelore e duas Canchim), num total de 20 baias.

A ração foi formulada segundo o NRC (1996), visando teor de NDT de $63 \%$ e $12 \%$ de $\mathrm{PB}$, para permitir ganho de peso diário de 1,0 $\mathrm{kg}_{\text {.animal.dia }}{ }^{-1}$. Com base na matéria seca a ração foi composta por 55,07\% de silagem, $42,31 \%$ milheto grão finamente moído, 0,86\% uréia e 1,76\% mistura mineral (Tabela 18).

No caso do tratamento T4, no qual foi adicionado milheto no momento da ensilagem, este cereal presente foi computado na formulação e o tratamento recebeu dose complementar no momento do fornecimento aos animais, de modo que todos os tratamentos recebessem a mesma quantidade de concentrado. 
Tabela 18. Participação dos ingredientes na formulação das rações experimentais

\begin{tabular}{lcc}
\hline & \multicolumn{2}{c}{$\%$ da MS } \\
Ingrediente & T1, T2, T3 e T5 ${ }^{1}$ & T4 \\
\hline Silagem de capim & 55,0 & 80,9 \\
Milheto grão moído & 42,3 & 16,4 \\
Uréia & 0,9 & 0,9 \\
Mineral $^{2}$ & 1,8 & 1,8
\end{tabular}

T1: Umidade original, partícula maior, sem inoculante bacteriano; T2: Umidade original, partícula menor, sem inoculante bacteriano; T3: Emurchecido, partícula maior, sem inoculante bacteriano;T4: Umidade original, partícula maior, sem inoculante + milheto; T5: Umidade original, partícula menor, com inoculante bacteriano.

${ }^{2}$ Composição do suplemento mineral (por kg): 6,00 \% Ca; 4,00 \% P; 1,61 \% K; 3,70 \% S; 8,00 $\% \mathrm{Na} ; 12,05$ \% Cl; 5,00 \% Mg; 15 ppm Co; 800 ppm Cu; 20 ppm I; 3100 ppm Fe; 2850 ppm Mn; 20 ppm Se; 3500 ppm Zn; 200000 UI Vit. A; 25000 UI Vit. D; 1800 UI Vit. E.

Ao final do período de 58 dias os animais foram submetidos a novo jejum exclusivo de alimento por 12 horas e pesados, computando assim seu ganho de peso no período.

$\mathrm{Na}$ Tabela 19 consta a composição bromatológica das rações completas fornecidas. 
Tabela 19. Composição bromatológica das rações experimentais

\begin{tabular}{lccccc}
\hline & \multicolumn{5}{c}{ Composição da rações (\% MS) } \\
Variável ${ }^{2}$ & T1 & T2 & T3 & T4 & T5 \\
\hline PB, \% MS & 13,9 & 14,5 & 14,1 & 13,5 & 13,8 \\
FDN, \% MS & 43,3 & 44,1 & 43,9 & 44,1 & 42,6 \\
FDA, \% MS & 27,7 & 27,9 & 28,5 & 28,0 & 28,5 \\
LIG, \% MS & 3,7 & 3,9 & 3,7 & 3,8 & 3,3 \\
HEMI, \% MS & 15,9 & 15,9 & 15,7 & 16,4 & 14,1 \\
CEL, \% MS & 24,7 & 24,5 & 25,2 & 25,0 & 25,8 \\
CZ, \%MS & 8,9 & 8,78 & 9,16 & 8,8 & 8,9 \\
1 T1: Umidade original, partícula maior, sem inoculante bacteriano; T2: Umidade original, \\
partícula menor, sem inoculante bacteriano; T3: Emurchecido, partícula maior, sem inoculante \\
bacteriano; T4: Umidade original, partícula maior, sem inoculante + milheto; T5: Umidade \\
original, partícula menor, com inoculante bacteriano. \\
${ }^{2}$ MS = matéria seca; CZ = cinzas; PB = proteína bruta; FDN = fibra em detergente neutro; FDA \\
= fibra em detergente ácido; LIG = lignina; HEMI = hemicelulose; CEL = celulose; N-FDA = \\
nitrogênio insolúvel em FDA.
\end{tabular}

\subsubsection{Procedimento experimental}

A rotina consistiu das seguintes atividades:

$\rightarrow$ Retirada diária das sobras de ração dos cochos, quantificação para ajuste do consumo e amostragem semanal;

$\rightarrow$ Retirada de silagens dos silos. Após ter sido removida a porção deteriorada, determinada através de avaliação visual, esta porção foi quantificada diariamente em cada silo, para determinação de perdas por deterioração, sendo descartada em seguida;

$\rightarrow$ Procedeu-se à retirada da quantidade de silagem diária, que foi fornecida às baias em cada tratamento. A forragem foi colocada em vagão forrageiro marca SILTOMAC ${ }^{\circledR}$ Ração Total 203, em seguida foi adicionado o 
concentrado, procedendo-se à mistura dos ingredientes e descarregando-se a ração total nos cochos de cada baia;

$\rightarrow$ Simultaneamente, amostras de silagem e de concentrados foram coletadas para determinação do teor de matéria seca e ajuste do consumo;

$\rightarrow$ Amostras de sobras, silagens e concentrados coletadas foram congeladas para posteriores análises bromatológicas;

$\rightarrow$ Semanalmente, foi retirado de cada silo um cubo de 0,027 $\mathrm{m}^{3}$ (30x30×30 cm) para determinação das densidades e análises dos parâmetros físicos como o tamanho de partícula, densidade de massa verde (DMV) e densidade de matéria seca (DMS);

$\rightarrow$ Com freqüência semanal, as baias tiveram o piso raspado e os bebedouros lavados.

\subsection{Análises realizadas}

\subsubsection{Analises químico-bromatológicas}

Amostras de sobras e silagens coletadas semanalmente foram descongeladas e juntamente com amostras de concentrados, foram secas em estufa de ventilação forçada a $60^{\circ} \mathrm{C}$ (Silva, 1981), por 72 horas, e moídas em 1 $\mathrm{mm}$ para posteriores análises bromatológicas.

Devido ao grande número de amostras geradas a determinação da composição químico-bromatológica da forragem, das silagens e dos concentrados foi realizada utilizando-se o método de espectroscopia de reflectância de infravermenlho proximal (NIRS) (Shenk \& Westernhaus, 1991; Berzaghi et al., 1997; Mathison et al., 1999; Cozzolino et al., 2001), visando a redução no número de amostras e otimização tanto do tempo como dos custos de análises.

O material moído foi escaneado para obtenção dos espectros NIRS. O equipamento utilizado foi o espectrômetro modelo NIRS 5000 (NIRSystems ${ }^{\circledR}$, 
Silver Spring, MD, USA) acoplado a um microcomputador equipado com softwear WinISI II versão 6.2 (Intrasoft International, PA), com dois tipos de células de leitura para escanear as amostras: quando estas apresentavam quantidades suficientes, foi utilizada a célula modelo Transport quarter cup (código IH - 0379), caso contrário, utilizou-se a de modelo Micro sample cup (código IH - 0348).

As amostras foram escaneadas nesse equipamento obtendo leituras compreendidas entre os comprimentos de onda de 700 a $2100 \mathrm{~nm}$. Esses espectros foram armazenados em curvas log $(1 / R$, onde $R$ é o valor da reflectância), em intervalo de $2 \mathrm{~nm}$. Utilizaram-se os métodos de seleção de amostras existentes no softwear do equipamento e foram descartadas as amostras distantes mais de $3 \mathrm{H}$ (distância padronizada de Mahalanobis) da média, e essas foram tidas como outliers. Adotou-se uma distância mínima de 0,6 H entre amostras para seleção daquelas em que seriam efetuadas as análises bromatológicas convencionais, ou seja, onde o valor outlier $(H)$ é usado para eliminar amostras com distâncias espectrais muito afastadas da média da população (Shenk \& Westernhaus, 1991; Mathison et al., 1999).

O procedimento realizado pelo programa foi o seguinte: as amostras para calibração foram selecionadas com base no espectro, usando o subprograma ISI SELECT (Shenk \& Westernhaus, 1991), que começa identificando o espectro representativo de espectros vizinhos, descartando os similares. Então, o programa avalia todas as amostras remanescentes e repete o procedimento até que só reste o mínimo possível de amostras.

O procedimento SELECT usa uma distância $\mathrm{H}$ padronizada entre pares de amostras para definir vizinhanças e baseia-se na suposição de que somente uma amostra seja requerida para representar todas as amostras contidas naquela grupo de vizinhança. Quanto mais heterogêneo for o grupo de amostras escaneadas maior vai deverá o número de amostras selecionadas para abranger toda amplitude espectral (Mathison et al., 1999). 
Nas amostras selecionadas foram realizadas análises convencionais, ou métodos de referência (Berzaghi et al., 1997), do teor CZ (AOAC, 1980), do teor de PB, obtidas através da combustão das amostras segundo o método de Dumas, utilizando-se um auto-analisador de nitrogênio, marca LECO ${ }^{\circledR}$, modelo FP-528 (Wiles et al., 1998). Teores de fibra insolúvel em detergente neutro (FDN) foram obtidos através do método proposto pela ANKOM Fiber Analyser (ANKOM Technology Corporation, Fairport, NY). Os teores de fibra insolúvel em detergente ácido (FDA) e lignina (LIG) foram calculados segundo método de Van Soest et al. (1991). Análise de nitrogênio na fibra insolúvel em detergente ácido (N-FDA) foi conduzida segundo metodologia proposta por Krishnamoorthy et al. (1982).

As amostras selecionadas para análise em química líquida convencional foram representativas de variação espectral. Após análise química convencional os valores foram inseridos no banco de dados e permitiram ao softwear do programa NIRS predizer o valor das demais amostras não analisadas.

Após a realização dessas análises foram utilizados métodos estatísticos existentes no softwear do NIRS para o desenvolvimento de equações de predição dos teores dos componentes da análise químicobromatólógica para o grupo remanescente de amostras.

\subsubsection{Extrato aquoso}

De uma segunda amostra, mantida com umidade original, foi obtido o extrato aquoso (Kung Jr. et al., 1984), no qual foi registrado o valor de $\mathrm{pH}$ e determinado o teor de carboidratos solúveis (Dubois et al., 1956) com leitura em $490 \mathrm{~nm}$. Também no mesmo extrato aquoso foi analisado o teor de $\mathrm{N}^{-\mathrm{NH}_{3}}$ (Chaney \& Marbach, 1962), com leitura em 550nm, ambos lidos em espectrofotômetro JENWAY-6405 UV/VIS ${ }^{\circledR}$. 


\subsubsection{Avaliações dos parâmetros físicos}

Nos cubos de $0,027 \mathrm{~m}^{3}(30 \times 30 \times 30 \mathrm{~cm})$, retirados semanalmente de cada silo, foram determinadas as densidades de massa verde (DMV) e da matéria seca (DMS), tamanhos de partículas e porosidade. Delimitava-se a área desejada, em um ponto central na face exposta do silo e com auxílio de faca e moto-serra retirava-se a silagem cuidadosamente. A massa de silagem de cada cubo foi quantificada para determinar a DMV e em seguida uma amostra foi destinada à determinação do tamanho de partícula (Lammers et al., 1996) e uma outra amostra foi seca a $60^{\circ} \mathrm{C}$ (Silva, 1981), para determinação da DMS.

A densidade laboratorial foi determinada segundo Giger-Riverdin (2000), usando um método que consiste em inserir amostra seca e moída em cilindro de vidro graduado, procedendo-se à agitação por tempo determinado, anotando o peso e o volume ocupado a cada nova adição de amostra e subseqüente agitação. Com estes dados de densidade laboratorial calculou-se então a porosidade (Williams, 1994), conforme Equação 7, descrita a seguir:

Porosidade $=1-\frac{\text { densidade de massa verde }\left(\mathrm{kg} \cdot \mathrm{m}^{-3}\right) \times \text { teor de MS (\%) }}{\text { densidade laboratorial }\left(\mathrm{kg} \cdot \mathrm{m}^{-3}\right)}$

A porosidade é expressa em $\mathrm{m}^{3}$ de poros por $\mathrm{m}^{3}$ de massa ensilada, ou porcentagem (Pitt \& Muck, 1993).

Baseada na metodologia da estratificação em peneiras utilizando o sistema PennState Particle Size Separator (Lammers et al., 1996) foi realizada avaliação do tamanho de partículas, definindo-se a proporção de material que ficou retido em cada estrato, ou seja, acima de 1,89 cm, entre 1,89 e 0,78 e abaixo de $0,78 \mathrm{~cm}$. 


\subsection{Delineamento experimental e análise estatística}

Foi utilizado um delineamento em blocos casualizados, sendo quatro baias por tratamento (unidades experimentais). Houve efeito de blocos (leves e pesadas) para ganho de peso, confirmando as expectativas de heterogeneidade da população, justificando a adoção de blocos no delineamento inicial.

Os dados foram analisados utilizando-se o procedimento GLM do programa estatístico SAS ${ }^{\circledR}$, versão 6.12 para Windows ${ }^{\circledR}$ (SAS, 1996). Para efeito de comparação de médias entre tratamentos foi utilizado o teste de média dos mínimos quadrados LSMEANS, com nível de significância de 5\%. Quando necessária a exploração das tendências, foi declarado o nível de significância observado.

\subsection{Resultados e discussão}

\subsubsection{Parâmetros físicos das silagens e perdas por deterioração}

Resultados referentes às características físicas das silagens estão apresentados na Tabela 20. A redução no tamanho da partícula não foi eficiente em elevar $(P<0,05)$ as densidades de matéria seca $(D M S)$ e de massa verde (DMV). No tratamento com adição de milheto grão moído no momento da ensilagem (T4), a DMS tendeu a ser maior (156 kg. $\mathrm{m}^{-3}$ ) que nos demais tratamentos, pela contribuição do milheto, assim como sua densidade laboratorial também foi superior. 
Tabela 20. Determinação de parâmetros físicos das silagens armazenadas em silos tubulares revestidos por lona plástica

\begin{tabular}{ccccc}
\hline Trat $^{1}$ & $\begin{array}{c}\mathrm{DMV}^{2^{\mathrm{k}}} \\
\mathrm{kg} \cdot \mathrm{m}^{-3}\end{array}$ & $\begin{array}{c}\mathrm{DMS}^{3} \\
\mathrm{~kg} \cdot \mathrm{m}^{-3}\end{array}$ & $\begin{array}{c}\text { Dens. Lab. } \\
\mathrm{kg} \cdot \mathrm{m}^{-3}\end{array}$ & $\begin{array}{c}\text { Porosidade } \\
\%\end{array}$ \\
\hline T1 & $535^{\mathrm{a}}$ & $142^{\mathrm{ab}}$ & $253^{\mathrm{b}}$ & $45^{\mathrm{b}}$ \\
T2 & $523^{\mathrm{a}}$ & $131^{\mathrm{b}}$ & $274^{\mathrm{b}}$ & $52^{\mathrm{a}}$ \\
T3 & $460^{\mathrm{b}}$ & $135^{\mathrm{ab}}$ & $273^{\mathrm{b}}$ & $50^{\mathrm{ab}}$ \\
T4 & $505^{\mathrm{ab}}$ & $156^{\mathrm{a}}$ & $302^{\mathrm{a}}$ & $48^{\mathrm{ab}}$ \\
T5 & $487^{\mathrm{ab}}$ & $122^{\mathrm{b}}$ & $269^{\mathrm{b}}$ & $55^{\mathrm{a}}$ \\
Médias & 502 & 137 & 274 & 50 \\
\hline
\end{tabular}

${ }^{1}$ Tratamentos: T1: Umidade original, partícula maior, sem inoculante bacteriano; T2: Umidade original, partícula menor, sem inoculante bacteriano; T3: Emurchecido, partícula maior, sem inoculante bacteriano;T4: Umidade original, partícula maior, sem inoculante + milheto; T5: Umidade original, partícula menor, com inoculante bacteriano.

${ }^{2} \mathrm{DMV}=$ densidade de material verde (na umidade natural), em $\mathrm{kg} \cdot \mathrm{m}^{-3}$.

${ }^{3} \mathrm{DMS}=$ densidade de MS, em $\mathrm{kg} \cdot \mathrm{m}^{-3}$.

${ }^{4}$ Densidade laboratorial da MS.

* Médias seguidas de mesma letra na coluna não diferem pelo Teste de Tukey $(P<0,05)$.

O emurchecimento (T3) fez com que a DMV ficasse abaixo $\left(460 \mathrm{~kg} \cdot \mathrm{m}^{-3}\right)$ dos valores observados para os demais tratamentos, embora não tenha diferido significativamente das silagens com umidade original (T5) ou adicionada com milheto (T4). Apesar desta menor DMV não ter sido suficiente para reduzir sua DMS, que foi compensada pelo maior teor de MS.

Com a redução no tamanho de partícula esperava-se melhor acomodação da massa reduzindo os poros mas, contrariando a expectativa, ao se reduzir tamanho de partículas (T2 e T5) a porosidade não foi diminuída (Tabela 20), igualando-se aos tratamentos emurchecido (T3) e com adição de milheto (T4). Pode ser atribuído à substituição de menor número de poros maiores por maior número de poros menores. Quanto ao tratamento 
emurchecido (T3), a elevada porosidade explica-se pela baixa densidade da massa verde (DMV) e dificuldade de compactação deste tipo de material.

Os valores de densidade apresentados neste trabalho são inferiores aos obtidos por Igarasi (2002), que foram 643 e $487 \mathrm{~kg} \cdot \mathrm{m}^{-3}$ para tratamentos com umidade original e emurchecidos, respectivamente, e Loures (2004) que obteve, para os mesmos tratamentos, os respectivos valores de 795 e 773 $\mathrm{kg} \cdot \mathrm{m}^{-3}$. Apesar destes autores terem utilizado a mesma espécie e o mesmo procedimento de colheita que no presente experimento, seus dados de densidades foram obtidos em mini silos, o que permite maior compactação por pisoteio, explicando as maiores densidades.

Em levantamento realizado por Igarasi (2002) em propriedades rurais a DMV esteve entre 413 e 891, com média de $605 \mathrm{~kg} \cdot \mathrm{m}^{-3}$, sendo as maiores densidades obtidas em silagens com maior umidade. Para os mesmos silos a DMS variou de 87 a $230 \mathrm{~kg} \cdot \mathrm{m}^{-3}$, com média de $141 \mathrm{~kg} \cdot \mathrm{m}^{-3}$. Esta média de DMV está acima da observada nesse caso $\left(502 \mathrm{~kg} \cdot \mathrm{m}^{-3}\right)$, contudo a DMS condiz com os valores obtidos no presente experimento $\left(137 \mathrm{~kg} \cdot \mathrm{m}^{-3}\right)$, de modo que os valores de densidades obtidos nesse experimento estão dentro da amplitude esperada.

As menores densidades observadas justificam-se pelo próprio mecanismo de ensilagem em silos tubulares revestidos por lona plástica (bag) que não permitem compactação tão intensa como seria num silo trincheira ou poço, pelo fato de não possuírem paredes rígidas que suportem maior pressão exercida na compactação.

Foi observado que durante confecção dos silos, o capim picado que alimentava a esteira da ensiladora formava grandes emaranhados devido a partículas mais grosseiras e estes eram empurrados pelo mecanismo da máquina de modo que uma vez dentro da bolsa não eram mais desfeitos, mesmo aumentando a pressão de compactação. Consequentemente, a superfície das bolsas permaneceu muito irregular, denunciando desuniformidade de compactação e espaços vazios. 
A única tentativa de aumentar a pressão de compactação na ensiladora, visando a elevação da densidade, não foi bem sucedida pois devido ao baixo teor de MS da forragem ensilada (em torno de 20\%) começou a gerar muito efluente o que não era desejável. A ensilagem de partículas mais uniformes e menores permite obter silagens com alta densidade em silos tipo bag.

Narciso Sobrinho et al. (1998a) avaliando o emurchecimento de capim Elefante de 19 para 25\% de MS reduziram em 2,4\% a DMV, variando de 536 para $523 \mathrm{~kg} \cdot \mathrm{m}^{-3}$, redução menor que os $14 \%$ aqui obtidos (535 vs $460 \mathrm{~kg} \cdot \mathrm{m}^{-3}$ ). Como mencionado previamente o emurchecimento reduz a densidade de massa verde e quando associado ao mecanismo de ensilagem em silos tubulares essa redução foi acentuada.

Resultados referentes aos valores médios de perdas por deterioração estão apresentados na Tabela 21, na qual os tratamentos são comparados. Não houve redução de perdas com a diminuição no tamanho de partícula $(P=0,60)$, o que se explica pela $D M V$, que não foi elevada com redução no tamanho de partículas. Outro fato que pode ser notado é que houve tendência $(P=0,09)$ do uso do inoculante bacteriano elevar as perdas, contrariando as expectativas quanto ao uso deste tipo de aditivo. 
Tabela 21. Perdas de silagem por deterioração em silos tubulares revestidos por lona plástica

\begin{tabular}{|c|c|c|c|c|c|c|c|c|c|}
\hline \multirow[b]{3}{*}{ Perdas $^{2}$} & \multirow[b]{2}{*}{ T1 } & \multicolumn{3}{|c|}{ Tratamentos $^{1}$} & \multicolumn{5}{|c|}{ Comparações entre tratamentos ${ }^{3,4}$} \\
\hline & & $\mathrm{T} 2$ & T3 & $\mathrm{T} 4$ & T5 & $\mathrm{T} 1 \times \mathrm{T} 2 \mathrm{~T} 1 \times \mathrm{T} 3$ & $\mathrm{~T} 3 \times \mathrm{T} 4$ & T2 $\times$ T5 & $C V^{5}$ \\
\hline & 16,8 & 14,3 & 29,1 & 17,9 & 22,5 & NS & * & $\dagger$ & 48 \\
\hline \multicolumn{10}{|c|}{${ }^{1}$ T1: Umidade original, partícula maior, sem inoculante bacteriano; T2: Umidade original, partícula menor, sem inoculante bacteriano; T3: } \\
\hline \multicolumn{10}{|c|}{$\begin{array}{l}\text { Emurchecido, partícula maior, sem inoculante bacteriano;T4: Umidade original, partícula maior, sem inoculante + milheto; T5: Umidade } \\
\text { original, partícula menor, com inoculante bacteriano. }\end{array}$} \\
\hline \multicolumn{10}{|c|}{2 perdas por deterioração, \% do total retirado do silo. } \\
\hline \multirow{2}{*}{\multicolumn{10}{|c|}{$\begin{array}{l}{ }^{3} \text { T1xT2 = efeito tamanho de partícula; T1xT3 = efeito de emurchecimento; T3xT4 = efeito da adição de carboidratos; T2xT5 = efeito da } \\
\text { adição de inoculante bacteriano. }\end{array}$}} \\
\hline & & & & & & & & & \\
\hline \multicolumn{10}{|c|}{${ }^{4} N S=P>0,10,{ }^{*} P<0,05,{ }^{*} P<0,01, \dagger<0,10$} \\
\hline & & & & & & & & & \\
\hline
\end{tabular}


O emurchecimento (T3) elevou em $73 \%$ as perdas por deterioração $(P<0,05)$, em relação ao tratamento de mesmo tamanho de partícula e com umidade original (T1), pelo fato desta silagem ter alcançado baixa densidade da massa ensilada (460 $\mathrm{kg} \cdot \mathrm{m}^{-3}$ ). Este é um comportamento esperado segundo Marsh (1979) que enfatiza que a forragem emurchecida requer atenção extra no que diz respeito à sua consolidação.

O emurchecimento pode diminuir a densidade da massa ensilada e a concentração de ácido lático, conforme obtido por Narciso Sobrinho et al. (1998a) e Marsh (1979). Muck \& Holmes (2000) afirmaram que com o emurchecimento ocorre aumento na DMS, embora isto não tenha ocorrido no presente experimento, pois sua baixa DMV não chegou a ser compensada pela elevada concentração de MS. A diminuição na densidade da massa faz com que aumentem as perdas por respiração (Muck \& Shinners, 2001) e deterioração, fato este observado no presente experimento.

O emurchecimento permite retenção de oxigênio na massa devido sua menor DMV, promovendo o desenvolvimento de microrganismos aeróbios que degradam a silagem, além de apresentar fermentação mais restrita que contribui pouco para a queda no valor de $\mathrm{pH}$. Mesmo esta forragem tendo apresentando menor poder tampão que as demais (Tabela 16) seu valor final de pH não foi inferior aos demais (Tabela 17), ou seja, o poder tampão não foi o único fator limitante à queda no $\mathrm{pH}$.

No entanto, a redução no teor de umidade foi eficiente em inibir clostrídios, fato confirmado pelo elevado teor protéico mantido na silagem. Os teores de PB determinados na forragem emurchecida na ensilagem e na silagem foram, respectivamente de 9,66 e 9,57\%. E, consequentemente, o teor de nitrogênio amoniacal foi menor nesta silagem (4,56\% $\mathrm{N}$ total) que naquelas ensiladas com umidade original ( $8,06 \% \mathrm{~N}$ total). Isto comprova o relato de Ávila et al. (2003a, b) e Pedreira et al. (2001) de que a redução no teor de umidade na ensilagem é um poderoso controlador da atividade clostridica dentro do silo através do aumento da pressão osmótica. 
Ao se comparar métodos para elevar o teor de MS no momento da ensilagem (Tabela 21), pode ser observado que as perdas foram superiores $(P<0,05)$ na silagem emurchecida $(29,1 \%)$ que naquela adicionada com milheto $(17,98 \%)$, que mostrou-se mais eficiente, contribuindo também na elevação da densidade da massa seca ensilada.

Rony et al. (1984) ensilando alfafa com capins timóteo emurchecidos, em silos tipo torre e tipo bag chegaram a 9,5 e 8,1\% de perdas por deterioração, enquanto que silagens de milho perderam $2,4 \%$ e $4,8 \%$, respectivamente. Alegou-se que silagens de gramíneas atingiram maiores temperaturas que silagens de milho nos 10 dias após fechamento e estas foram maiores em silos tipo bag. Isso foi correlacionado com as maiores perdas por deterioração em silagens de gramíneas nos silos tipo bag, relacionado à pior compactação, freqüentemente obtida neste tipo de silo, devido à maior retenção de oxigênio responsável pela elevação de temperatura da massa. Mesmo assim as perdas relatadas por estes autores estão muito abaixo da média de 20,1\% apresentada no presente experimento.

Este fato contraria alguns autores que descrevem efeitos positivos do uso de inoculante, como maiores recuperações da matéria seca e digestibilidade, sendo que o menor $\mathrm{pH}$ obtido poderia diminui a população de microrganismos indesejáveis (Muck \& Kung Jr., 1997; Winters et al., 2001). Bactérias homoláticas poderiam restringir a produção de etanol e nitrogênio amoniacal, dominando a flora epifítica e estimulando fermentação mais propícia à conservação da forragem (Kung Jr \& Ranjit, 2001; Winters et al., 2001).

Há relatos que podem explicar porque as perdas foram superiores na silagem inoculada. Muck \& Kung Jr (1997) citaram que apesar do inoculante apresentar as vantagens citadas acima, após a abertura do silo seu efeito pode ser negativo sobre a estabilidade aeróbica (tendência ao aquecimento quando exposto ao ar) e isto será tanto pior quanto maior o $\mathrm{pH}$.

McDonald (1981) complementa que somente em anaerobiose é que bactérias homoláticas adicionadas via inoculante predominam e são eficientes, 
mas em condições aeróbicas e com substrato disponível as bactérias epifíticas podem dominar e consumir os carboidratos que serviriam de substrato às homoláticas. É que o ácido lático, embora preserve a silagem dentro do silo é menos inibitório do que o ácido acético contra fungos e leveduras (Panditharatne et al., 1986) e pode ainda ser usado como substrato para o crescimento por leveduras durante a exposição aeróbia.

Kung \& Ranjit (2001) comprovaram este efeito mostrando que silagem inoculada apresentou sinais de deterioração em metade do tempo em relação àquela não inoculada, apesar de possuir pH menor $(4,12$ vs 4,70$)$.

Após exposição ao ar há dois picos de aumento de temperatura, o primeiro devido à ação de leveduras, o qual ocorre em até três dias e o segundo causado por fungos, ocorre após mais três a quatro dias. Como principais substratos para fermentações destes organismos estão os carboidratos e o ácido lático, mais encontrados em silagens inoculadas ou emurchecidas. Então, o pH e a temperatura tendem a aumentar, perdendo-se matéria seca e aminoácidos, gerando amônia que ajuda contribui na elevação do pH (McDonald, 1981).

Quanto ao uso de inoculante bacteriano houve tendência $(P=0,09)$ do seu uso elevar as perdas (22,5\%) em relação à silagem de mesmo teor de umidade e tamanho de partícula (14,3\%). A silagem com inoculante bacteriano apresentou na face exposta do silo, durante todo o período experimental, muitos pontos com presença de fungos. Nos demais tratamentos as porções deterioradas eram restritas às áreas de contato com a lona plástica e na porção inferior para onde o efluente foi drenado.

Essa observação pode comprovar o que foi exposto acima, ou seja, a ineficiência do inoculante em manter a estabilidade aeróbica. Além de fatores como espécie forrageira, composição química, tipo de bactéria, teores de umidade e carboidratos solúveis interferirem na eficiência do uso de inoculantes bacterianos em silagens de gramíneas (Vilela, 1998). 
Embora os aditivos possam contribuir para melhorar a qualidade das silagens, as respostas ao uso destes aditivos não têm sido consistentes. Quando as técnicas de ensilagem são adotadas adequadamente, o uso de aditivos oferece poucas vantagens e estes devem ser considerados quando for difícil satisfazer todas as exigências para obter uma silagem de boa qualidade. Além disso, nem sempre seus benefícios se estendem até ao animal traduzindo-se em melhor desempenho (Muck \& Shinners, 2001).

Peixoto et al. (2003) inoculando capim Elefante, com e sem emurchecimento, relataram que o inoculante permitiu a diminuição do $\mathrm{pH}$ tanto para forragens emurchecidas como sem emurchecimento. Mas no presente trabalho o inoculante não contribuiu muito para redução no pH (T5), que foi de 4,72 para silagem inoculada contrastando com a média de 4,84 para silagens sem inoculante (Tabela 17).

As elevadas perdas que ocorreram no presente trabalho podem ser atribuídas à reduzida taxa de retirada diária o que possibilitou prolongada exposição ao ar da camada frontal do silo. Nesses casos mantêm-se as proporções entre os tratamentos, mas eleva-se a quantidade absoluta de perdas.

O ácido lático sempre foi tido como o ácido mais desejável para a preservação da silagem, inibindo desenvolvimento de microrganismos como os clostrídios. No entanto, quanto mais preservada a silagem maior a chance de apresentar reduzida estabilidade aeróbica após abertura, fornecendo substrato aos microrganismos aeróbicos. Neste momento o ácido acético, mais do que o lático, evitaria o desenvolvimento de microrganismos indesejáveis (Panditharatne et al., 1986) evitando aparecimento de fungos. Porém o ácido acético é tido como um fator mais limitante à ingestão do que o ácido acético (Silveira, 1980).

Frente a esse paradoxo fica difícil estabelecer as devidas proporções entre estes fatores para que chegue-se a um ponto de equilíbrio. 


\subsubsection{Composição das silagens e formulação das rações}

$\mathrm{Na}$ Tabela 19 são apresentadas as composições das silagens utilizadas no experimento. Comparando o tamanho médio de partícula da forragem $(3,84 \mathrm{~cm})$ na ensilagem (Tabela 16$)$ observa-se redução em relação ao tamanho médio obtido nas silagens $(2,44 \mathrm{~cm})$. Esse fato ocorreu pois o mecanismo de admissão e compressão da ensiladora, através de um rolo dentado, promoveu a repicagem deste material, fragmentando-o. Também pode ser observado que tanto o emurchecimento como a adição de milheto, visando a elevação no teor de MS na ensilagem, foram eficientes em preservar a PB gerando menos nitrogênio amoniacal nas silagens com umidade original.

Outro fato interessante observado é quanto ao teor de carboidratos. Segundo Marsh (1979), o emurchecimento gera a diminuição no teor de carboidratos solúveis devido hidrólise e respiração pela longa exposição da planta ceifada. No entanto, o teor de MS do emurchecido superior a 33\% atrasa ou evita uma fermentação desejável, pela falta de liberação de líquido intracelular como substrato, preservando os carboidratos presentes na forragem emurchecida. Embora a forragem emurchecida perca mais carboidrato no campo, da porção remanescente, pouco será usado dentro do silo, resultando em menor concentração de ácidos e maior pH nesta silagem.

Também Vilela (1998) evidenciou maior teor de carboidrato solúvel em silagem emurchecida. No presente experimento as forragens com umidade original no momento da ensilagem (Tabela 16) apresentaram média de 4,2\% de carboidratos solúveis na MS e no tratamento emurchecido a média foi de 0,92 $\%$, evidenciando significativa redução com a desidratação da forragem.

Nesse experimento, apesar de ter havido maior preservação de carboidrato solúvel na silagem emurchecida $(2,35 \% \mathrm{MS})$ que nas demais $(1,54 \% \mathrm{MS})$, o seu pH $(4,79)$ não foi significativamente inferior à média das demais silagens $(4,82)$, o que demonstra que silagem emurchecida atinge $\mathrm{pH}$ a estabilidade em valor de $\mathrm{pH}$ superior ao das silagens com umidade original. Nas 
silagens não emurchecidas o carboidrato foi consumido e convertido a ácidos que diluídos não contribuiriam para a queda no $\mathrm{pH}$ ou foram perdidos por lixiviação via efluente.

No caso do inoculante bacteriano Haigh (1998) notou preservação de carboidratos solúveis em silagens de Lolium e Trifolium inoculadas, porém sem alterar significativamente o $\mathrm{pH}(4,37$ vs 4,39). Mas o uso de inoculante bacteriano não foi efetivo em preservar carboidrato no presente experimento nem reduziu significativamente o valor de $\mathrm{pH}$ (Tabela 17).

Outro efeito do uso de inoculante, observado por Muck \& Kung Jr (1997), seria a redução nos níveis de amônia, indicando melhor preservação da proteína. Porém, no presente experimento, ao comparar T2 e T5 pode ser visto que isto não ocorreu pois com inoculante o teor de PB da silagem foi menor $(10,20$ vs $8,54 \%$ PB) e seu teor de amônia maior (5,81 vs $10,14 \% \mathrm{~N}$ total), podendo dizer-se que foi observado efeito contrário ao esperado.

Outro meio de reduzir a produção de amônia seria a elevação do teor de MS da forragem pela adição de material absorvente ou pelo emurchecimento. Este efeito foi observado por Narciso Sobrinho et al. (1998a) que ao ensilarem capim Elefante emurchecido reduziram o teor de nitrogênio amoniacal de 11,16 para $5,19 \%$ do $\mathrm{N}$ total. No presente trabalho o teor de amônia foi reduzido de 8,24\% em silagem com umidade original para 4,56\% N total em silagem emurchecida e o tratamento mais eficiente em evitar a produção de amônia foi o T4, adicionado com milheto na ensilagem (Tabela 17).

Benachio (1965), citado por Narciso Sobrinho et al. (1998b), classifica silagens muito boas como aquelas contendo de 0 a $10 \%$ de $\mathrm{N}$ amoniacal (\% N total), boas as que contêm de 10 a 15\%, aceitáveis aquelas com 15 a 20\% e ruins aquelas que apresentam acima de $20 \%$ de N amoniacal. Silveira (1975) define uma boa silagem quando possui pH inferior a 4,2 e nitrogênio amoniacal até $8 \%$ do $\mathrm{N}$ total. Assim as silagens obtidas neste trabalho seriam 
consideradas muito boas quanto ao teor de nitrogênio amoniacal mas insatisfatórias quanto ao $\mathrm{pH}$.

Estas observações comprovam a teoria de Marsh (1979) na qual o nitrogênio volátil na forma de amônia (\% $\mathrm{N}$ total) é diminuído ao se elevar o teor de MS da forragem na ensilagem, criando um meio com maior pressão osmótica, desencorajando a ação de clostrídios. Isto torna silagens emurchecidas estáveis em $\mathrm{pH}$ de valor 5 ou até superiores.

Mesmo assim, Woolford (1984) cita que o maior benefício do emurchecimento sobre a fermentação da silagem é a maior tolerância relativa das homoláticas à baixa umidade em relação aos clostrídios que ficam são limitados.

A Tabela 18 apresenta a participação percentual de cada ingrediente na ração, visando o fornecimento de 12\% de PB e permitir ganho médio diário de $1,00 \mathrm{~kg}$. No caso do tratamento que havia recebido milheto no momento da ensilagem, este foi computado de modo que todos os tratamentos recebessem a mesma quantidade do cereal, seja via silagem ou fornecido na mistura da ração.

\subsubsection{Ingestão de matéria seca, ganho de peso e conversão alimentar}

Resultados referentes à ingestão de matéria seca (IMS), ganho de peso (GPV) e conversão alimentar (CA) estão apresentados na Tabela 22. Não houve efeito da redução no tamanho de partícula, uso de inoculante bacteriano, emurchecimento ou adição de milheto na ensilagem sobre a ingestão de matéria seca, que apresentou média de 2,36\% PV. Apenas houve uma tendência $(P=0,06)$ de maior ingestão com o emurchecimento $(2,51 \% P V)$ do que com adição de milheto (2,03\% PV), ambos objetivando elevar o teor de matéria seca.

Tanto o ganho de peso como a ingestão de matéria seca obtidos apresentaram-se dentro do predito pelo NRC (1996). A ingestão de MS média 
Tabela 22. Ganho de peso vivo (GPV), ingestão de matéria seca (IMS) e conversão alimentar (CA) em novilhas de corte recebendo rações à base de silagens de capim Tanzânia

\begin{tabular}{|c|c|c|c|c|c|c|c|c|c|c|c|c|}
\hline \multirow[b]{2}{*}{ Variáveis } & \multicolumn{6}{|c|}{ Tratamentos $^{1}$} & \multicolumn{6}{|c|}{ Comparação entre tratamentos ${ }^{2,3}$} \\
\hline & $\mathrm{T} 1$ & $\mathrm{~T} 2$ & T3 & T4 & T5 & Médias & $\mathrm{T} 1 \times \mathrm{xT} 2$ & T1xT3 & T3xT4 & T2xT5 & $\mathrm{T} 1 \mathrm{xT} 4$ & $\mathrm{CV}^{4}$ \\
\hline GPV, kg.animal.dia ${ }^{-1}$ & 0,95 & 1,06 & 1,10 & 1,02 & 1,02 & 1,0 & NS & $\dagger$ & NS & NS & NS & 6,5 \\
\hline IMS, \% do peso vivo & 2,33 & 2,53 & 2,51 & 2,03 & 2,42 & 2,4 & NS & NS & $\dagger$ & NS & NS & 7,4 \\
\hline CA, kg MS.kg GPV ${ }^{-1}$ & 8,28 & 8,21 & 8,11 & 6,81 & 8,12 & 7,9 & NS & NS & NS & NS & NS & 7,9 \\
\hline
\end{tabular}

${ }^{1}$ Tratamentos: T1: Umidade original, partícula maior, sem inoculante bacteriano; T2: Umidade original, partícula menor, sem inoculante bacteriano; T3: Emurchecido, partícula maior, sem inoculante bacteriano;T4: Umidade original, partícula maior, sem inoculante + milheto; T5: Umidade original, partícula menor, com inoculante bacteriano.

${ }^{2}$ Comparações entre tratamentos: T1xT2 = efeito tamanho de partícula; T1xT3 = efeito de emurchecimento; T3xT4 = efeito da adição de carboidratos; T2xT5 = afeito da adição de inoculante bacteriano.

${ }^{3} \mathrm{NS}=\mathrm{P}>0,10,{ }^{*} \mathrm{P}<0,05,{ }^{* *} \mathrm{P}<0,01, \dagger<0,10$.

${ }^{4}$ coeficiente de variação. 
foi de $8,23 \mathrm{~kg}$ MS.animal.dia ${ }^{-1}$, permanecendo bem próximo aos $8,78 \mathrm{~kg}$ MS.animal.dia ${ }^{-1}$ preditos pelo NRC (1996).

Estes valores de ingestão de matéria seca, com base no peso vivo (2,36\%), são próximos aos 2,5\% PV obtidos por Restle et al. (2003) utilizando silagem de capim Papuã com 35\% de concentrado e aos 2,42\% PV observados por Pilar et al. (1994) utilizando silagem de capim Elefante e $48 \%$ de concentrado.

Ao contrário dos resultados obtidos no presente experimento, Narciso Sobrinho et al. (1998b) observaram aumento na ingestão de MS de capim Elefante emurchecido em 6,1\%, recebendo como suplemento somente sal mineral, e Silveira et al. (1980) obtiveram aumento de 19\%. Talvez a silagem emurchecida não tenha promovido aumento significativo na ingestão neste trabalho pela elevada participação de concentrado na ração (45\%) que anulou este efeito.

Marsh (1979) afirma que, de modo geral, o emurchecimento eleva a ingestão de matéria seca, mas esta será reduzida em dietas com elevada proporção de concentrado, o que pode explicar a falta de efeito no presente trabalho, no qual a participação do concentrado na ração foi de $45 \%$.

Silveira et al. (1980) relataram que apesar de haver baixo consumo de silagens confeccionadas com forragens de elevado teor de umidade, 0 coeficiente de correlação entre estes parâmetros foi somente $R=0,47$, mostrando que outros fatores estariam interferindo no consumo das silagens sem emurchecimento, e um deles seria a presença de ácidos, como o acético, explicando sua reduzida aceitação.

Não houve efeito dos tratamentos $(P>0,05)$ sobre o ganho de peso vivo dos animais, ficando em torno de 1,03 kg.animal.dia ${ }^{-1}$, havendo apenas tendência da silagem emurchecida $\left(1,10 \mathrm{~kg}\right.$.animal.dia $\left.{ }^{-1}\right)$ ser superior ao tratamento de mesmo tamanho de partícula sem o emurchecimento $(0,95$ kg.animal.dia $\left.{ }^{-1}\right)$. Estes valores estão um pouco acima dos obtidos $(0,800$ 
kg.animal ${ }^{-1}$ ) por Restle et al. (2003) com silagem de capim Papuã e por Pilar et al. (1994) com silagem de capim elefante $\left(0,895 \mathrm{~kg}\right.$.animal.dia $\left.{ }^{-1}\right)$.

No entanto, no presente experimento as novilhas Canchim tiveram ganho de peso superior às Nelore (1,19 vs $0,87 \mathrm{~kg})$, e como isto era previsto confirmou-se a necessidade de estabelecer delineamento em blocos.Marsh (1979) afirma que silagens emurchecidas proporcionam maiores níveis de produção animal, em comparação a silagens sem emurchecimento, e novamente os dados deste trabalho discordam desta posição, pois animais consumindo silagem emurchecida não apresentaram melhor ganho de peso, embora tenha havido uma tendência $(P=0,10)$.

Quanto à conversão alimentar, como os tratamentos adotados não apresentaram efeitos significativos sobre a ingestão e o ganho de peso, conseqüentemente não houve efeito na conversão alimentar que apresentou média de 7,91 kg MS.kg GPV ${ }^{-1}$. Valor este pior do que o observado por Restle et al. (2003) que foi de $6,27 \mathrm{~kg} \mathrm{MS.kg} \mathrm{GPV}{ }^{-1}$ e por Pilar et al. (1994) que obtiveram 5,02 kg MS.kg GPV ${ }^{-1}$, ambos utilizando dietas com silagens de capim e proporção de concentrado semelhante a deste experimento. No presente experimento novilhas Canchim apresentaram melhor conversão alimentar do que as Nelore (7,33 vs 8,48), mostrando-se mais eficientes.

Segundo Restle et al. (2003) um dos problemas na utilização de forrageiras não-graníferas para a produção de silagem é o baixo teor de MS no momento da ensilagem. Teores de MS inferiores a $25 \%$ impedem fermentação lática adequada, produzindo silagem de má qualidade, elevada produção de efluente, coloração escura e odor ácido, tendendo à putrefação, ocasionando acentuadas perdas e redução no consumo voluntário dos animais.

Esta descrição aplica-se ao que ocorreu no presente trabalho, pois a forragem na ensilagem apresentava em média 20\% de MS resultando em silagens de aspecto escuro e odor desagradável, com elevadas perdas por putrefação (Tabela 21). No entanto, a ingestão de matéria seca alcançada não compatível porque no momento do fornecimento a porção deteriorada foi 
retirada e somente a porção considerada adequada foi fornecida aos animais além, é claro, da participação do concentrado que contribui para elevar a ingestão da ração como um todo.

Quanto ao uso de inoculante bacteriano há relatos de que permite elevações na ingestão de matéria seca de 11 a 29\% (Charmley et al., 1996; Clavero, 2001; Winters et al., 2001), no ganho de peso de 12 a 33\% (Charmley et al., 1996; Clavero,2001; Winters et al., 2001) e na conversão alimentar em 16\% (Winters et al., 2001).

Porém, trabalhos realizados por Rodrigues et al. (2001) e Grise et al. (2001) contrariam estas afirmações, demonstrando que silagens de espécies tropicais não-graníferas inoculadas com bactérias não obtiveram melhorias nas características qualitativas, fermentativas e nutricionais das silagens, não alterando sua qualidade de conservação e o consumo de matéria seca. Mesmo com silagens de milho Guim et al. (1995) não obtiveram melhores resultados quanto ao consumo e composição bromatológica ao usar o inoculante bacteriano.

Coan et al. (2001) avaliaram o efeito do inoculante enzimáticobacteriano, a composição química e a qualidade das silagens dos capins Tanzânia e Mombaça. Estes autores também observaram que o uso do inoculante não melhorou as características qualitativas, fermentativas e nutricionais das silagens, independentemente do cultivar e da idade de corte. Bergamaschine et al. (1998), trabalhando com capim Tanzânia, e Haigh (1998) também não preconizaram sua adoção.

Restle et al. (2003) também não constataram efeito da adição do inoculante bacteriano sobre o consumo de silagens de capim Papuã, que foi de 2,56 e 2,43\% PV para silagens sem e com inoculante, respectivamente. Esta média de consumo não diferiu dos 2,62\% PV obtidos com silagem mista de milho e sorgo, todas contendo 35\% de concentrado. Estes mesmos autores não observaram diferenças para silagens com e sem inoculante para os ganhos de peso $\left(0,781\right.$ e 0,818 $\mathrm{kg}$.animal.dia $\left.{ }^{-1}\right)$ e conversões alimentares $(6,25$ e 6,28), 
concluindo que o uso de inoculante bacteriano no processo de ensilagem do capim Papuã não favoreceu melhoria da qualidade da silagem, consumo diário de matéria seca e desempenho animal.

Pelos dados discutidos acima fica evidente que, ao aplicar tratamentos à forragem no momento da ensilagem, seus efeitos podem ser manifestados em diferentes fases que ocorrem desde a preservação da silagem dentro do silo, passando pela estabilidade aeróbica, perdas por deterioração, aceitação e consumo pelo animal e, finalmente traduzindo-se em desempenho. Assim o benefício desses efeitos devem ser avaliados durante todo o processo, considerando perdas e ganhos em cada etapa.

\subsection{Conclusões}

Ao avaliar as perdas em silos tubulares revestidos por lona plástica observou-se que a inoculação bacteriana e o emurchecimento não se constituíram em ganhos de eficiência em silagens de capim Tanzânia.

Como os procedimentos adotados na ensilagem do capim Tanzânia não promoveram alterações no consumo, desempenho e conversão alimentar dos animais, a decisão pela adoção de práticas no processo de ensilagem deverá considerar a magnitude das perdas ocorridas na fermentação e após abertura do silo, com vistas à economicidade e na racionalização das atividades, tornando o processo de ensilagem mais eficiente. 


\section{CONCLUSÕES GERAIS}

Procedimentos como alteração no teor de matéria seca, através do emurchecimento ou adição de milheto, uso de inoculante bacteriano e redução no tamanho de partícula apresentaram efeitos sobre as variáveis químicofísicas das silagens, embora os animais não tenham sido sensíveis a estas variações mantendo inalterados o consumo, a digestibilidade de nutrientes e o desempenho.

A avaliação com animais recebendo rações com máxima participação de volumoso na forma de silagem de capim Tanzânia demonstrou o potencial para este tipo de volumoso, através das variáveis avaliadas, assim como indicou a possibilidade de melhorar os índices de desempenho de animais à medida em que se eleva a participação de concentrado na ração total, porém sem diferença entre tratamentos.

As variáveis analisadas indicam que a combinação apropriada do conjunto de métodos utilizados na ensilagem faz com que se ganhe eficiência no processo.

Considerando que os tratamentos impostos não alteraram as perdas totais na forma de gases e efluente, pois estas duas variáveis foram inversamente proporcionais, a decisão pelo método mais adequado na ensilagem deverá considerar menores perdas por deterioração após abertura do silo ou a melhor operacionalidade, tornando o processo de ensilagem mais eficiente e com os menores custos.

Embora este trabalho tenha cumprido com os objetivos propostos, o fato das avaliações terem sido conduzidas sob condições diferentes, em cada um dos três experimentos, não seria correto englobar todos os pontos de 
interesse na tentativa de fechar o ciclo, desde a colheita até o cocho. Por exemplo, não se pode somar perdas por gases e efluente, em mini silos, com perdas por deterioração, em silos tubulares revestidos por lona plástica, tentando quantificar as perdas totais, pois ocorreram em situações diferentes.

$O$ ideal seria que um mesmo experimento englobasse todas as variáveis, gerando uma planilha única, a fim de quantificar potencialmente cada fator envolvido no processo completo. 


\section{REFERÊNCIAS BIBLIOGRÁFICAS}

AGUIAR, R.N.S.; CRESTANA, R.F.; BALSALOBRE, M.A.A. et al. Avaliação das perdas de matéria seca em silagens de capim Tanzânia. In: REUNIÃO ANUAL DA SOCIEDADE BRASILEIRA DE ZOOTECNIA, 37., Viçosa, 2000. Anais. Viçosa: SBZ, 2000. p.32.

AGUIAR, R.N.S.; CRESTANA; R.F.; BALSALOBRE; M.A.A. et al. Efeito do tamanho de partícula na composição da fração nitrogenada de silagem de capim Tanzânia. In: REUNIÃO ANUAL DA SOCIEDADE BRASILEIRA DE ZOOTECNIA, 38., Piracicaba, 2001. Anais. Piracicaba: FEALQ, 2001. p.314-316.

ALBERTO, G.; PORTELLA, J.S.; OLIVEIRA, O.L.P. Efeito da adição de grão de sorgo moído e do emurchamento sobre a qualidade da silagem de capim Elefante (Pennisetum purpureum, Schum). Revista da Sociedade Brasileira de Zootecnia, v.22, p.1-11, 1993.

ALLEN, M.S. Relationship between fermentation acid production in the rumen and the requirement for physically effective fiber. Journal of Dairy Science, v.80, p.1447-1462, 1997.

ALLEN, M.S. Effects of diet on short-term regulation of feed intake by lactating dairy cattle. Journal of Dairy Science, v.83, p.1598-1624, 2000. 
ASSOCIATION OF OFFICIAL AGRICULTURAL CHEMISTS. Official methods of analysis. 13. ed. Washington, 1980. 1015p.

ÁVILA, C.L.S.; PINTO, J.C.; EVANGELISTA, A.R.; et al. Perfil de fermentação das silagens de capim Tanzânia com aditivos. I - Teores de matéria seca e proteína bruta (compact disc). In: REUNIÃO ANUAL DA SOCIEDADE BRASILEIRA DE ZOOTECNIA, 40., Santa Maria, 2003. Anais. Santa Maria: SBZ, 2003a.

ÁVILA, C.L.S.; PINTO, J.C.; FIGUEIREDO, H.C.P.; et al. Perfil de fermentação das silagens de capim Tanzânia com aditivos. II - Concentrações de carboidratos (compact disc). In: REUNIÃO ANUAL DA SOCIEDADE BRASILEIRA DE ZOOTECNIA, 40., Santa Maria, 2003. Anais. Santa Maria: SBZ, 2003b.

BALSALOBRE, M.A.A. Valor alimentar do capim Tanzânia irrigado. Piracicaba, 2002. 113 p. Tese (Doutorado) - Escola Superior de Agricultura "Luiz de Queiroz", Universidade de São Paulo.

BALSALOBRE, M.A.A.; NUSSIO, L.G.; MARTHA JUNIOR, G.B. Controle de perdas na produção de silagens de gramíneas tropicais (compact disc). In: REUNIÃO ANUAL DA SOCIEDADE BRASILEIRA DE ZOOTECNIA, 38., Piracicaba, 2001. Anais. Piracicaba: FEALQ, 2001b.

BALSALOBRE, M.A.A.; NUSSIO, L.G.; SANTOS, P.M. et al. Dry matter losses in Tanzânia grass (Panicum amximum, Jacq., cv Tanzânia) silage. In: INTERNATIONAL GRASSLAND CONGRESS, 19., São Pedro, 2001. Proceedings. Piracicaba: FEALQ, 2001a. p.789-790. 
BERGAMASCHINE, A.F.; ISEPON, O.J.; GUATURA, A.S. et al. Efeitos da adição de resíduo de milho e da cultura enzimo-bacteriana sobre a qualidade da silagem de capim Tanzânia (compact disc). In: REUNIÃO ANUAL DA SOCIEDADE BRASILEIRA DE ZOOTECNIA, 35., Botucatu, 1998. Anais. Botucatu: SBZ, 1998.

BERZAGHI, P.; COZZI, G.; ANDRIGHETTO, I. The use of near infrared analysis for in situ studies. Journal of Dairy Science, v.80, p.3263-3270, 1997.

BRODERICK, G.A. Quantifying forage protein quality. In: FAHEY JR., G.C. (Ed.) Forage quality, evaluation, and utilization. Madison, ASA, 1994. cap.5, p.200-228.

BROWN, W.F.; K PITMAN, W.D. Concentration and degradation of nitrogen and fibre fractions in selected tropical grasses and legumes. Tropical Grasslands, v.25, p.305-312, 1991.

CASTRO, F.G.; NUSSIO, L.G.; SIMAS, J.M. et al. Perfil bacteriológico da silagem de Tifton 85 (Cynodon sp.) sob efeito de pré-emurchecimento e de inoculante bacteriano-enzimático. In: REUNIÃO ANUAL DA SOCIEDADE BRASILEIRA DE ZOOTECNIA, 38., Piracicaba, 2001. Anais. Piracicaba: FEALQ, 2001a. p.203-204.

CASTRO, F.G.; NUSSIO, L.G.; SIMAS, J.M. et al. Parâmetros físico-químicos da silagem de Tifton 85 (Cynodon sp.) sob efeito de pré-emurchecimento e de inoculante bacteriano-enzimático. In: REUNIÃO ANUAL DA SOCIEDADE BRASILEIRA DE ZOOTECNIA, 38., Piracicaba, 2001. Anais. Piracicaba: FEALQ, 2001b. p.270-272. 
CHANEY, A.L.; MARBACH, E.P. Modified reagents for determination of urea and ammonia. Clinical Chemistry, v.8, p.130-137, 1962.

CHARMLEY, E.; WINTER, K.A.; MCRAE, K.B. et al. Effect of inoculation on silage quality and performance of steers fed grass and cereal silages either alone or in combination. Canadian Journal of Animal Science, v.76, p.571-577, 1996.

CHUDY, A.; SCHMIDT, T.; GLATZLE, A. Continuous digestibility assessment of tropical grass. In: INTERNATIONAL GRASSLAND CONGRESS, 19., São Pedro, 2001. Proceedings. Piracicaba: FEALQ, 2001. p 368.

$\mathrm{CHURCH}$, D.C. The ruminant animal digestive physiology and nutrition. 2.ed. Waveland: New Jersey, 1993. 564p.

CLAVERO, T. Quality and nutritive value of Mott dwarf elephantgrass silage with bilogical additives. In: INTERNATIONAL GRASSLAND CONGRESS, 19., São Pedro, 2001. Proceedings. Piracicaba: FEALQ, 2001. p.770.

COAN, R.M.; VIEIRA, P.F.; SILVEIRA, R.N. et al. Efeitos do inoculante enzimático-bacteriano sobre a composição química, digestibilidade e qualidade das silagens dos capins Tanzânia e Mombaça. In: REUNIÃO ANUAL DA SOCIEDADE BRASILEIRA DE ZOOTECNIA, 38., Piracicaba, 2001. Anais. Piracicaba: FEALQ, 2001. p.124-126. 
COELHO, R.M. Efeitos da concentração de matéria seca e do uso de inoculante bacteriano-enzimático, na silagem de Tifton 85 (Cynodon spp.), sobre a digestão de nutrientes, parâmetros ruminais e comportamento ingestivo em novilhos de corte em crescimento. Piracicaba, 2002. 122p. Dissertação (Mestrado) - Escola Superior de Agricultura "Luiz de Queiroz", Universidade de São Paulo.

CORREAA, L.A.; CORDEIRO, C.A. Silagem de capim como estratégia de manejo intensivo de pastagens. São Carlos: EMBRAPA:CPPSE, 2000. 6p. (Comunicado Técnico, 26).

COZZOLINO, D.; ACOSTA, Y.; GARCIA, J. Aplication of near infrared reflectance spectroscopy (NIRS) to forage evaluation in Uruguay. In: INTERNATIONAL GRASSLAND CONGRESS, 19., São Pedro, 2001. Proceedings. Piracicaba: FEALQ, 2001. p. 370.

CRESTANA, R.F.; AGUIAR, R.N.S.; BALSALOBRE, M.A.A. et al. Efeito da fermentação na fração fibra de silagens de capim Tanzânia. In: REUNIÃO ANUAL DA SOCIEDADE BRASILEIRA DE ZOOTECNIA, 38., Piracicaba, 2001. Anais. Piracicaba: FEALQ, 2001. p.354-355.

DAWSON, L.E.R.; FERRIS, C.P.; STEEN, R.W.J. et al. The effects of wilting grass before ensiling on silage intake. Grass and Forage Science, v.54, p.237-247, 1999.

DIXON, R.M.; STOCKDALE, C.R. Associative effects between forages and grains: consequences for feed utilisation. Australian Journal of Agricultural Research, v.50, p.757-773, 1999. 
DUBOIS, M.; K.A GILES, J.K.; HAMILTON, P.A. et al. Colorimetric method for determination of sugars and related substances. Analytical Chemistry, v.28, p.350-356, 1956.

ELLIS, W.C.; MATIS, J.H.; HILL, T.M. et al. Methodology for estimating digestion and passage kinetics of forages. In: FAHEY JR., G.C. (Ed.). Forage quality, evaluation, and utilization. Madison: ASA, 1994. cap.17, p.682-756.

EUCLIDES, V.P.B. Valor alimentício de espécies forrageiras do gênero Panicum. In: SIMPÓSIO SOBRE MANEJO DA PASTAGEM, 12., Piracicaba, 1995. Anais. Piracicaba: FEALQ, 1995. p.245-273.

EVANGELISTA, A.R.; LIMA, J.A.; SIQUEIRA, G.R., et al. Aditivos na ensilagem de coastcross ( Cynodon dactylon (L.) Pers.). 1 . Farelo de trigo e polpa cítrica. In: REUNIÃO ANUAL DA SOCIEDADE BRASILEIRA DE ZOOTECNIA, 38., Piracicaba, 2001. Anais. Piracicaba: FEALQ, 2001. p.7172.

FAHEY, G.C.; HUSSEIN, H.S. Forty years of forage quality research: accomplishments and impact from na animal nutrition perspective. Crop Science, v.39, p.4-12, 1999.

FERREIRA, J.J.; MARQUES NETO, J.; MIRANDA, C.S. efeito da associação de capim elefante (Pennisetum purpureum, Schum) cv. Cameroon e milho na qualidade de silagem e desempenho de novilhas. Revista da Sociedade Brasileira de Zootecnia, v.17, p.268-280, 1988. 
FIRKINS, J.L.; BERGER, L.L.; MERCHEN, N.R. et al. Effects of feed intake and protein degradability on ruminal characteristics and site of digestion in steers. Journal of Dairy Science, v.69, p.2111-2123, 1986.

GIGER-RIVERDIN, S. Characterisation of feedstuffs for ruminants using some physical parameters. Animal Feed Science and Technology, v.86, p.53-69, 2000.

GORDON, C.H.; WIESMAN, H.G.; DERBYSHIRE, J.C. et al. Effect on silage of chopping and bruising the forage. Journal of Dairy Science, v.42, p.13941395, 1958.

GRISE, M.M.; JOBIM, C.C.; CECATO, U. et al. Efeito do uso de inoculantes na composição química e $\mathrm{pH}$ da silagem de milheto (Pennisetum americanum (L.) Leeke). In: REUNIÃO ANUAL DA SOCIEDADE BRASILEIRA DE ZOOTECNIA, 38., Piracicaba, 2001. Anais. Piracicaba: FEALQ, 2001. p.132-133.

GUIM, A.; ANDRADE, P.; MALHEIROS, E.B. Efeito de inoculante microbiano sobre o consumo, degradação in situ e digestibilidade aparente de silagem de milho (Zea mays L). Revista da Sociedade Brasileira de Zootecnia, v.24, p.1045-1053, 1995.

HAIGH, P.M. Effect of additives on grass silage fermentation and effluent production, and on intake and liveweight change of young cattle. Journal Of Agricultural Engineering Research, v.69, p.141-148, 1998.

HAIGH, P.M. Effluent production from grass silages treated with additives and made in large-scale bunker silos. Grass and Forage Science, v.54, p.208218, 1999. 
HARRISON, J.H.; BLAUWIEKEL, R. Fermentation and utilization of grass silage. Journal of Dairy Science, v.77, p.3209-3235, 1994.

HEIMBECK, W.; COENEN, M.; SUEDEKUM, K.; et al. Nutrient content and protein quality in grass silages. Journal of Animal Science, v.86, Suppl. 1, p.230, 2003.

HOLMES, C.W.; MATHWEUS, P.N. Feeding of conserved forage-implications to grassland management and production. In: INTERNATIONAL GRASSLAND CONGRESS, 19., São Pedro, 2001. Proceedings. Piracicaba: FEALQ, 2001. p.671.

HUHTANEN, P., VANHATALO, A. Ruminal and total plant cell-wall digestibility estimed by a combined in situ method utilizing mathematical models. British Journal of Nutrition, v.78, p.583-598, 1997.

IGARASI, M.S. Controle de perdas na ensilagem de capim Tanzânia (Panicum maximum Jacq. Cv Tanzânia) sob os efeitos do teor de matéria seca, do tamanho de partícula, da estação do ano e da presença do inoculante bacteriano. Piracicaba, 2002. 152p. Dissertação (Mestrado) - Escola Superior de Agricultura "Luiz de Queiroz", Universidade de São Paulo.

JONES, D.I.; JONES, R. The effect of crop characteristics and ensiling methodology on grass silage effluent production. Journal of Agricultural Engineering Research, v.60, p.73-81, 1995. 
JUNQUEIRA, R.M.D. Efeito da idade de corte sobre a produção, composição química-bromatológica e digestibilidade "in vitro" da matéria seca de Panicum maximum Jacq. Cv IAC-Centauro. Piracicaba, 1995. 88 p. Dissertação (Mestrado) - Escola Superior de Agricultura "Luiz de Queiroz", Universidade de São Paulo.

KEADY, T.W.J.; MAYNE, C.S. The effects of concentrate energy source on feed intake and rumen fermentation parameters of dairy cows offered a range of grass silage. Animal Feed Science and Technology, v.90, p.117129, 2001.

KEARNEY, P.C.; KENNEDY, W.K. Relationship between losses of fementable sugars and changes in organic acids of silage. Agronomy Journal, v.54, p.114-115, 1962.

KONONOFF, P.J.; HEIRINCHS, A.J.; LEHMAN, H.A. The effect of corn silage particle size on eating behaviour, chewing activities and rumen fermentation in lactating dairy cows. Journal of Dairy Science, v. 86, p.3343-3353, 2003.

KORNDÖRFER, C.M. Eficiência de utilização do feno de Brachiaria decumbens na alimentação de ovinos Santa Inês. Piracicaba, 1999. 110 p. Tese (Doutorado) - Escola Superior de Agricultura "Luiz de Queiroz", Universidade de São Paulo.

KRAUS, T. J.; KOEGEL, R. G.; STRAUB, R. J. et al. Leachate conductivity as an index for quantifying level of forage conditioning. In: ASAE ANNUAL INTERNATIONAL MEETING. Minneapolis, 1997. Proceedings. Minneapolis: ASAE, 1997. p.1-12. 
KRISHNAMOORTHY, U.C.; MUSCATO, T.V.; SNIFFEN, C.J. et al. Nitrogen fraction in selected feedstuffs. Journal of Dairy Science, v.65, p.217, 1982.

KUNG JUNIOR., L.; GRIEVE, D.B.; THOMAS, J.W. et al. Added ammonia or microbial inocula for fermentation and nitrogenous compounds of alfalfa ensiled at various percents of dry matter. Journal of dairy Science, v.67, p.299-306, 1984.

KUNG JUNIOR, L.; RANJIT, N.K. The effect of Lactobacillus buchneri and other additives on the fermentation and aerobic stability of barley silage. Journal of Dairy Science, v.84, p.1149-1155, 2001.

LAMMERS, B.P.; BUCKMASTER, D.R.; HEIRINCHS, A.J. A simple method for the analysis of particle sizes of forage and total mixed rations. Journal of Dairy Science, v.79, p.922-928, 1996.

LAVEZO, W. Silagem de capim Elefante. Informe Agropecuário, v.11, p.50-57, 1985.

LIMA, J.A.; EVANGELISTA, A.R.; SANTOS, R.V. et al. Aditivos na silagem de coastcross (Cynodon dactylon (L.) Pers.) .2 . Sacharina e fubá. In: REUNIÃO ANUAL DA SOCIEDADE BRASILEIRA DE ZOOTECNIA, 38., Piracicaba, 2001. Anais. Piracicaba: FEALQ, 2001. p.72-73.

LOURES, D.R.S. Enzimas fibrolíticas e emurchecimento no controle de perdas da ensilagem e na digestão de nutrientes em bovinos alimentados com rações contendo silagem de capim Tanzânia. Piracicaba, 2004. 146 p. Tese (Doutorado) - Escola Superior de Agricultura "Luiz de Queiroz", Universidade de São Paulo. 
LOURES, D.R.S.; NUSSIO, L.G.; PAZIANI, S.F. et al. Uso de enzimas fibrolíticas e conteúdo de matéria seca em silagens de capim Tanzânia (Panicum maximum Jacq.) sobre o comportamento ingestivo em bovinos de corte (compact disc). In: REUNIÃO ANUAL DA SOCIEDADE BRASILEIRA DE ZOOTECNIA, 40., Santa Maria, 2003. Anais. Santa Maria: SBZ, 2003a.

LOURES, D.R.S.; NUSSIO, L.G.; PAZIANI, S.F. et al. Effect of dry matter content and fibrolytic enzymes in Tanzânia grass (Panicum maximum Jacq.) silage on the digestive parameters of beef steers. In: WORLD CONFERENCE ON ANIMAL PRODUCTION, 9.; REUNIÃO DA ASSOCIAÇÃO LATINOAMERICANA DE PRODUÇAO ANIMAL, 18., Porto Alegre, 2003. Proceedings. Porto Alegre, 2003b. p.25.

LOURES, D.R.S.; NUSSIO, L.G.; PAZIANI, S.F.; et al. Effect of dry matter, particle size and microbial/enzymatic additive on the aerobic stability of Tanzânia grass (Panicum maximum Jacq.) silage. In: WORLD CONFERENCE ON ANIMAL PRODUCTION, 9.; REUNIÃO DA ASSOCIAÇÃO LATINOAMERICANA DE PRODUÇAO ANIMAL, 18., Porto Alegre, 2003c. Proceedings. Porto Alegre, 2003c. p.114.

MAEKAWA, M.; BEAUCHEMIN, K.A.; CHRISTENSEN, D.A. Chewing activity, saliva production and ruminal $\mathrm{pH}$ of primiparous and multiparous lactanting dairy cows. Journal of Dairy Science, v. 85, p.1176-1182, 2002.

MANZANO, R.P. Consumo, parâmetros digestivos e comportamento de bovinos de corte em pastejo de capim Tanzânia (Panicum maximum Jacq. cv Tanzânia) suplementados com fontes de energia ou de proteína. Piracicaba, 2002. 160 p. Tese (Doutorado) - Escola Superior de Agricultura "Luiz de Queiroz", Universidade de São Paulo. 
MARI, L.J. Intervalo entre cortes em capim-Marandu (Brachiaria brizantha (Hochst. Ex A. Rich.) Stapf cv. Marandu) : Produção, valor nutritivo e perdas associadas à fermentação da silagem. Piracicaba, 2003. 138 p. Dissertação (Mestrado) - Escola Superior de Agricultura "Luiz de Queiroz", Universidade de São Paulo.

MARSH, R. The effects of wilting on fermentation in the silo and on the nutritive value of silage. Grass and Forage Science, v.34, p.1-10, 1979.

MARTINS, J.D.; RESTLE, J.; LANÇANOVA, J.A.C. Desempenho de terneiras de corte alimentadas com silagem ou pastagem cultivada. In: REUNIÃO ANUAL DA SOCIEDADE BRASILEIRA DE ZOOTECNIA, 35., Viçosa, 1988. Anais. Viçosa: SBZ, 1988. p.285.

MATHISON, G.W.; HSU, H.; SOOFI-SIAWASH, R. et al. Prediction of composition and ruminal degradability characteristics of barley straw by near infrared reflectance spectroscopy. Canadian Journal of Animal Science, v.19, p.519523, 1999.

McCULLOUG, M.E. Silage and silage fermentation. Feedstuffs, v.49, p.49-50, 1977.

McDONALD, P. The biochemistry of silage. New York: John Wiley, 1981. $207 p$.

McDONALD, P.J.; HENDERSON, A.R.; HERON, S.J.E. The biochemistry of silage. 2.ed. Mallow: Chalcombe Publ., 1991. 340p. 
MELLO, S.Q.S.; ALVES, J.B.; BERGAMASCHINE, A.F. et al. Degradabilidade in situ da matéria seca e da fibra em detergente neutro de cultivares de Panicum maximum Jacq. em três estádios de maturidade (compact disc). In: REUNIÃO ANUAL DA SOCIEDADE BRASILEIRA DE ZOOTECNIA, 39., Recife, 2002. Anais. Recife: SBZ, 2002.

MILFORD, R.; MINSON, D.J. Intake of tropical pasture species. In: INTERNATIONAL GRASSLAND CONGRESS, 9., São Paulo, 1966. Proceedings. São Paulo, 1966. p.815-822.

MUCK, R.E.; HOLMES, B.J. Factors affecting bunker silo densities. Applied Engineering in Agriculture, v.16, p.613-619, 2000.

MUCK, R. E.; HOLMES, B. J. Density and losses in pressed bag silos. In: ANNUAL INTERNATIONAL MEETING SPONSORED, Sacramento, 2001. Meetings. Sacramento : ASAE, 2001. p.1-20

MUCK, R. E.; KUNG JUNIOR, L. Effects of silages additives on ensiling. In: THE SILAGE: FIELD TO FEED BUNK NORTH AMERICAN CONFERENCE. Hershey, 1997. Proceedings. Hershey: National Regional Agricultural Engineering Service. 1997. p.187-199.

MUCK, R.E.; SHINNERS, K.J. Conserved forage (silage and hay): progress and priorities. In: INTERNATIONAL GRASSLAND CONGRESS, 19., São Pedro, 2001. Proceedings. Piracicaba: FEALQ, 2001. p.753.

NARCISO SOBRINHO, J.; MATTOS, H.B.; ANDRADE, J.B. et al. Silagem de capim Elefante, em três estádios de maturidade, submetido ao emurchecimento. II - Qualidade das silagens. Boletim da Indústria Animal, v.55, p. 113-125, 1998a. 
NARCISO SOBRINHO, J.; MATTOS, H.B.; ANDRADE, J.B. et al. Silagem de capim Elefante, em três estádios de maturidade, submetido ao emurchecimento. III - Valor nutritivo das silagens. Boletim da Indústria Animal, v.55, p.127-138, 1998b.

NASCIMENTO FILHO, V.F. Técnicas analíticas nucleares de fluorescência de raios $X$ por dispersão de energia (EDXRF) e por reflexão total (TXRF). Piracicaba: ESALQ, Departamento De Física e Meteorologia; CENA, 1999. 32p.

NATIONAL RESEARCH COUNCIL. Nutrients requirements of beef cattle. 7.ed. Washington: National Academy of Sciences, 1996. 242p.

NATIONAL RESEARCH COUNCIL. Nutrients requirements of dairy cattle. 7.ed. Washington: National Academy of Sciences, 2001. 381 p.

NONAKA, K.; KUME, S.; OHSHITA, T. Effect of maceration on in sacco degradability and energy content of low-moisture round bale alfalfa silage. In: INTERNATIONAL GRASSLAND CONGRESS, 19., São Pedro, 2001. Proceedings. Piracicaba: FEALQ, 2001. p.379-380.

NUSSIO, L.G.; CASTRO, F.G.; SIMAS, J.M.et al. Effects of dry matter content and microbial additive on Tifton 85 (Cynodon dactylon) wilted silage fermentation parameters. In: INTERNATIONAL GRASSLANDS CONGRESS, 19., São Pedro, 2001. Proceedings. Piracicaba: FEALQ, 2001. p.790-791. 
O'KIELY, P.O.; CLANCY, M.; DOYLE, E.M. Aerobic stability of grass silage mixed with a range of concentrate feedstuffs at feed-out. In: INTERNATIONAL GRASSLAND CONGRESS, 19., São Pedro, 2001. Proceedings. Piracicaba: FEALQ, 2001. p.794-795.

ORSKOV, E. R.; McDONALD, I. The estimation of protein degradability in the rumen from incubation measurements weight according to rate of passage. Journal of Agricultural Science, v.92, p.499-503, 1979.

PALMQUIST, D.L.; CONRAD, H.R. Origin of plasma fatty acids in lactating cows fed high grain or high fat diets. Journal of Dairy Science, v.54, p.10251033, 1971.

PANDITHARATNE, S.; ALLEN, V.G.; FONTENOT, J.P. et al. Ensiling characteristics of tropical grasses as influenced by stage of growth, additives and chopping lenght. Journal of Animal Science, v. 63, p. 197-207, 1986.

PATTERSON, J.A.; BELYEA, R.L.; BOWMAN, J.P.; et al. The impact of forage quality and supplementation regimen on ruminant animal intake and performance. In: FAHEY JR., G.C. (Ed.). Forage quality, evaluation, and utilization. Madison, ASA, 1994. cap. 2, p.59-114.

PEDREIRA, M.S.; MOREIRA, A.L.; REIS, R.A. et al. Características químicas e fermentativas do Tifton 85 (Cynodon ssp.) ensilado com diferentes conteúdos de matéria seca e níveis de polpa cítrica. In: REUNIÃO ANUAL DA SOCIEDADE BRASILEIRA DE ZOOTECNIA, 38., Piracicaba, 2001. Anais. Piracicaba: FEALQ, 2001. p.100-102. 
PEIXOTO, C.A.; FERREIRA, H.F.; PIRES, A.J.V.; et al. Inoculação de bactérias láticas em silagens de capim Elefante (Pennisetum purpureum Schum) com e sem pré-murchamento (compact disc). In: REUNIÃO ANUAL DA SOCIEDADE BRASILEIRA DE ZOOTECNIA, 40., Santa Maria, 2003. Anais. Santa Maria: SBZ, 2003.

PENATI, M.A.; CORSI, M.; DIAS, C.T.S. et al. Efeito do número de amostras e da relação dimensão-formato da moldura sobre o coeficiente de variação na determinação da massa de forragem em pastagens de capim Tanzânia (compact disc). In: REUNIÃO ANUAL DA SOCIEDADE BRASILEIRA DE ZOOTECNIA, 38., Piracicaba. Anais. Piracicaba: FEALQ, 2001.

PILAR, R.C.; RESTLE, J.; SANTOS, G.L. et al. Silagens de milho (Zea mays, L.) ou capim elefante (Pennisetum purpureum, Schum.) cv Napier para alimentação de terneiros de corte confinados. Ciência Rural, v.24, p.387392, 1994.

PINTO, A.A.; LAVEZZO, F.J.; CECATO, U. et al. Degradabilidade in situ de cultivares do gênero Panicum maximum (compact disc). In: REUNIÃO ANUAL DA SOCIEDADE BRASILEIRA DE ZOOTECNIA, 35., Botucatu. Anais. Botucatu: SBZ, 1998.

PITT, R.E.; MUCK, R.E. A diffusion model of aerobic deterioration at the exposed face of bunker silos. Journal of Agricultural Engineering Science, v.55, p.11-26, 1993.

PLAYNE, M.J.; McDONALD, P. The buffering constituents of herbage and of silage. Journal of the Science of Food and Agriculture, v.17, p.264-268, 1966. 
RESTLE, J.; NEUMANN, M.; BRONDANI, I.L. et al. Avaliação da silagem de capim Papuã (Brachiaria plantaginea) por meio do desempenho de bezerros de corte confinados. Ciência Rural, v.33, p.749-756, 2003.

RINNE, M.; HUHTANEN, P.; JAAKKOLA, S. Digestive processes of dairy cows fed silage harvested at four stages of grass maturity. Journal of Animal Science, v.80, p.1986-1998, 2002.

RODRIGUES, P.H.M.; ANDRADE, S.J.T.; FERNANDES, T. et al. Valor nutritivo de silagens inoculadas com bactérias ácido-láticas. 4 . Inoculação da silagem de capim Elefante. In: REUNIÃO ANUAL DA SOCIEDADE BRASILEIRA DE ZOOTECNIA, 38., Piracicaba, 2001. Anais. Piracicaba: FEALQ, 2001. p.911-913.

RONY, D.D.; DUPUIS, G.; PELLETIER, G. Digestbility by sheep and performance of steers fed silages stored in tower silos and silo pressed bags. Canadian Journal of Animal Science, v.64, p.357-364, 1984.

ROTZ, C.A.; MUCK, R.E. Changes in forage quality during harvest and storage. In: FAHEY JR., G.C. (Ed.). Forage quality, evaluation, and utilization. Madison, ASA, 1994. cap.20, p.828-868.

RYMER, C. The measurement of forage digestibility in vivo. In: GIVENS, D.I., OWEN, E., AXFORD, R.F.E. et al. (Ed.). Forage evaluation in ruminant nutrition. London: CAB International, 2000. p.113-134.

SAS INSTITUTE. The SAS System for Windows: version 6.12 (compact disc). Cary, 1996. 
SHENK, J.S.; WESTERHAUS, M.O. Population definition, sample selection, and calibration procedures for near infrared reflectance spectroscopy. Crop Science, v.31, p.469-474, 1991.

SILVA, D.J. Análise de alimentos (métodos químicos e biológicos). Viçosa: UFV, Impr. Univ., 1981. 166p.

SILVEIRA, A. C. Técnicas para produção de silagem. In: SIMPÓSIO SOBRE MANEJO DA PASTAGEM, 2., Piracicaba, 1975. Anais. Piracicaba:FEALQ, 1975. p.156-180.

SILVEIRA, A.C.; LAVEZZO, W.; SILVEIRA FILHO, S. et al. Consumo de silagens de capim Elefante (Pennisetum purpureum, Schum) submetidas a diferentes tratamentos. Revista da Sociedade Brasileira de Zootecnia, v.9, p.306-320, 1980.

SIMILI, F.F.; LIMA, M.L.P.; NOGUEIRA, J.R.; et al. Degradabilidade in situ do capim Elefante var. Guaçu e capim Tanzânia (compact disc). In: REUNIÃO ANUAL DA SOCIEDADE BRASILEIRA DE ZOOTECNIA, 39., Recife, 2002. Anais. Recife, 2001.

SOARES FILHO, C.V.; RODRIGUES, L.R.A. Evaluation of ten tropical grasses in the nothwest region of the state of São Paulo-Brazil. In: INTERNATIONAL GRASSLAND CONGRESS, 19., São Pedro, 2001. Proceedings. Piracicaba: FEALQ, 2001. p.418. 
SOUZA, A.L.; BERNARDINO, F.S.; GARCIA, R. et al. Valor nutritivo de silagem de capim Elefante Pennisetum purpureum Schum. cv. Cameroon com diferentes níveis de casca de café. In: REUNIÃO ANUAL DA SOCIEDADE BRASILEIRA DE ZOOTECNIA, 38., Piracicaba, 2001. Anais. Piracicaba: FEALQ, 2001. p.255-256.

STEEN, R.W.J.; KILPATRICK, D.J. The effects of the ratio of grass silage to concentrates in the diet and restricted dry matter intake on the performance and carcass composition of beef cattle. Livestock Production Science, v.62, p.181-192, 2000.

STEEN, R.W.J.; KILPATRICK, D.J.; PORTER, M.G. Effects of the proportions of high or medium digestibility grass silage and concentrates in the diet of beef cattle on liveweight gain, carcass composition and fatty acid composition of muscle. Grass and Forage Science, v.57, p.279-291, 2002.

TELLER, E.; VANBELLE, M.; KAMATALI, P. Chewing behaviour and voluntary grass silage intake by cattle. Livestock Production Science, v.33, p.215227, 1993.

THORNTON, R.F.; MINSON, D.J. The relationship between apparent retention time in the rumen, voluntary intake, and apparent digestibility of legume and grass diets in sheep. Australian Journal of Agricultural Research, v.24, p.889-898, 1973.

UDÉN, P.; COLUCCI, P.E.; VAN SOEST, P.J. Investigation of chromium, cerium, and cobalt as markers in digesta. Rate of passage studies. Journal of the Science of Food and Agriculture, v.31, p.625-632, 1980. 
VAN BRUCHEN, J.; BOSCH, M.W.; LAMMERS-WIENHOVEN, S.C.W. et al. Intake, rumination, reticulo-rumen fluid and particle kinetics, and faecal particle size in heifers and cattle fed grass hay and wilted grass silage. Livestock Production Science, v.27, p.297-308, 1991.

VANHATALO, A.; KETOJA, E. The role of the large intestines in post-ruminal digestion of feeds as measured by the mobile-bag method in cattle. British Journal of Nutrition, v.73, p.491-505, 1995.

VAN SOEST, P.J. Nutritional ecology of the ruminant. 2.ed. Ithaca: Cornell University, 1994. 476p.

VAN SOEST, P.J.; ROBERTSON, J.B.; LEWIS, E.B.A. Methods for dietary fiber, neutral detergent fiber and nonstarch polysaccharides in relation to animal nutrition. Journal of Dairy Science, v.74, p.3583-3589, 1991.

VIEIRA, J.D. Produção de matéria seca, coeficiente de digestibilidade e concentração de nutrientes no capim Colonião (Panicum maximum Jacq.) em função dos cortes aos 30, 45, 60 e 75 dias. Piracicaba, 1979. 71p. Dissertação (Mestrado) - Escola Superior de Agricultura "Luiz de Queiroz", Universidade de São Paulo.

VILELA, D. Aditivos para silagens de plantas de clima tropical (compact disc). In: REUNIÃO ANUAL DA SOCIEDADE BRASILEIRA DE ZOOTECNIA, 35., Botucatu, 1998. Anais. Botucatu: SBZ, 1998. 
VILELA, H.; BARBOSA, F.A., DIAS, E.T. et al. Qualidade das silagens de capim Elefante Paraíso (Pennisetum hybridum cv Paraíso) submetidas a três tempos de emurchecimento. In: REUNIÃO ANUAL DA SOCIEDADE BRASILEIRA DE ZOOTECNIA, 38., Piracicaba, 2001. Anais. Piracicaba: FEALQ, 2001. p.323-324.

ZIERENBERG, B.; FRIEDEL, K.; GLATZLE, A. et al. Assessment of stability of six tropical grasses using three different approaches. In: INTERNATIONAL GRASSLAND CONGRESS, 19., São Pedro, 2001. Proceedings. Piracicaba: FEALQ, 2001. p.786.

WALDO, D.R. Potential of chemical preservation and improvment of forages. Journal of Dairy Science, v.60, p.306-326, 1977.

WELCH, J.G. Physical parameters of fiber affecting passage from the rumen. Journal of Dairy Science, v.69, p.2750-2754, 1986.

WILES, P.G.; GRAY, I.K.; KISSLING, R.C. Routine analysis of protein by Kjeldahl and Dumas methods: review and interlaboratory study using dairy products. Journal of AOAC International, v.81, p.620-632, 1998.

WILLIAMS, A.G. The permeability and porosity of grass silage as affected by dry matter. Journal of Agriculture Engineering Science, v.59, p.133-140, 1994.

WILSON, J.R.; MCLEOD, M.N.; MINSON, D.J. Particle size reduction of the leaves of a tropical and a temperate grass by cattle. I . Effect of chewing during eating and varying times of digestion. Grass and Forage Science, v.4, p.55-63, 1989. 
WINTERS, A.L.; FYCHAN. R.; JONES, R. Effect of formic acid and a bacterial inoculant on the amino acid composition of grass silage and on animal performance. Grass and Forage Science, v. 56, p. 181-192, 2001.

WOOLFORD, M.K. The silage fermentation. New York: Marcel Dekker, 1984. $350 p$.

WRIGHT, D.A.; GORDON, F.J.; STEEN, R.W.J. et al. Factors influencing the responses in intake of silage and animal performance after wilting of grass before ensiling: a review. Grass and Forage Science, v.55, p.1-13, 2000. 